\title{
Menneskeverd - en utfordring for skole og samfunn
}

Ingrid Reite Christensen, Ådne Valen-Sendstad (red.) 


\section{Menneskeverd - en utfordring for skole og samfunn}



Ingrid Reite Christensen og Ådne Valen-Sendstad (red.)

\section{Menneskeverd - en utfordring for skole og samfunn}


(C) 2019 Ådne Valen-Sendstad, Ingrid Reite Christensen, Lena Lybæk, Åse-May Svendsen, Geir Winje, Rønnaug Sørensen, Eva Maagerø, Tollef Thorsnes og Sven Arntzen.

Dette verket omfattes av bestemmelsene i Lov om opphavsretten til åndsverk m.v. av 1961. Verket utgis Open Access under betingelsene i Creative Commons-lisensen CC-BY 4.0 (http://creativecommons.org/licenses/by/4.0/). Denne tillater tredjepart å kopiere, distribuere og spre verket i hvilket som helst medium eller format, og å remixe, endre, og bygge videre på materialet til et hvilket som helst formål, inkludert kommersielle, under betingelse av at korrekt kreditering og en lenke til lisensen er oppgitt, og at man indikerer om endringer er blitt gjort. Tredjepart kan gjøre dette på enhver rimelig måte, men uten at det kan forstås slik at lisensgiver bifaller tredjepart eller tredjeparts bruk av verket.

ISBN trykt bok: 978-82-02-66595-1

ISBN PDF: 978-82-02-59536-4

ISBN EPUB: 978-82-02-63268-7

ISBN HTML: 978-82-02-66798-6

ISBN XML: 978-82-02-66799-3

DOI: https://doi.org/10.23865/noasp. 90

Dette er en fagfellevurdert antologi.

Omslagsdesign: Cappelen Damm AS

Cappelen Damm Akademisk/NOASP noasp@cappelendamm.no 


\section{Innhold}

Forord

Kapittel 1 Introduksjon: Menneskeverd - mangfoldige forståelser

for en mangfoldig skole 11

Ådne Valen-Sendstad og Ingrid Reite Christensen

Kapittel 2 Verdig = vanlig og norsk: Nyankomne ungdommers verdighet $\mathrm{i}$ introduksjonsklasser.

Ingrid Reite Christensen

Kapittel 3 Menneskeverd - Utviklingshemming - Skole:

Verdighet som grunnlag for pedagogisk praksis

Lena Lybæk og Åse-May Svendsen

Kapittel 4 Verdighet i det pluralistiske klasserommet. .99

Geir Winje

Kapittel 5 Seksuell trakassering, verdighet og SKAM.

119

Rønnaug Sørensen

Kapittel 6 Menneskeverd og menneskerettighetsundervisning:

En sosialsemiotisk multimodalitetsanalyse og drøfting av verdighetsbegrepet i filmen A Path to Dignity:

The Power of Human Rights Education

Eva Maagerø og Ådne Valen-Sendstad

Kapittel 7 No mercy no dignity: Refleksjoner over et kunstnerisk utviklingsarbeid i Ål kyrkje 169

Tollef Thorsnes

Kapittel 8 Verdighet og selvbestemmelse- En aktørbasert

forestilling om menneskeverdet 191

Sven Arntzen

Kapittel 9 Menneskeverdet i tre nyere tolkninger som placeholder, heuristisk og «flytende signifikant» 215 Ådne Valen-Sendstad 



\section{Forord}

Menneskeverd - en utfordring for skole og samfunn er boka som tar opp spørsmålet: Er alle mennesker like mye verdt? For å svare på dette må man se nærmere på hvordan vi kan forstå menneskeverd. Menneskeverd og likeverd sees som grunnleggende for skolen, som er samfunnets viktigste aktør for menneskelig læring og utvikling. Samtidig er det mange eksempler på hvor vanskelig det er å sette begreper som likeverd og menneskeverd ut i praksis. I tillegg er det få debatter i skolen som berører selve forståelsen av hva menneskeverd er i skolen. Dette er oppsiktsvekkende, og vi ser det som en utfordring for både skole og samfunn.

Boka er en antologi på ni kapitler om menneskeverd i typiske «menneskefag» i skolen, som pedagogikk, filosofi, samfunnsfag, religion, norsk og kunst-og håndverk. Den gir en innføring i hva menneskeverd kan være både fra ulike teoretiske ståsted, og med eksempler fra skole og samfunnsliv. Kapitlene i boka reiser spørsmål om verdighet, likeverd, innenfor- og utenforskap, og hvilke ressurser mennesket tar i bruk i møte med utfordringer.

Menneskeverd er en del av folkespråket som «alle» har et eierskap til. Når ordet menneskeverd brukes, er det gjerne for å få fram noe som er viktig for mennesker. Verdighet og menneskeverd berører spørsmål som livets inngang, livets utgang, hva det vil si å leve godt individuelt og å delta og ivareta hverandre i et fellesskap. Begrepene anvendes for eksempel i argumenter for funksjonshemmedes barns rett til å være med på skoletur eller når det er spørsmål om vinservering på eldresenteret. Menneskeverd og verdighet framstår som umiddelbare og noenlunde felles begreper om noe vi opplever som riktig og viktig. De representerer kjerneverdier som ligger til grunn for en rekke samfunnsinstitusjoner, og inngår i politikk, helse, miljø og politiske beslutninger. Menneskeverd inngår også i komplekse filosofiske, juridiske eller religiøse spørsmål, samtidig som de er en del av hverdagsspråket for å beskrive grunnverdier for et godt liv.

Menneskeverd og verdighet ansees som grunnleggende i samfunnet. Skolen har et tydelig budskap om at menneskeverd er viktig. Skolen 
regnes som en grunnleggende samfunnsinstitusjon med menneskelig utvikling og dannelse i fokus, og fungerer som en slags leverandør for å gjøre elever til bidragsytere og medborgere i samfunnet. Samtidig er det få grunnleggende debatter i skolen om menneskeverdet.

Dette er problematisk, særlig i de tilfeller der elever, sterke som svake, ikke behandles med verdighet. Forskjellsbehandling og ekskludering er ikke bare et spørsmål om administrativ svikt i skolen eller mangel på gode praktiske rammer. Vi vil i stedet hevde at det handler om at menneskeverd og verdighet forstås og tolkes på ulike måter. Dersom begrepene om menneskeverd er uartikulerte, er det ingen garanti for hvilken behandling vi gir et menneske. Vi undersøker derfor ulike forstålser av menneskeverd, og med vekt på skole, utdanning og livslang læring.

Imidlertid finnes det mange ulike forståelser av begrepet menneskeverd. Menneskeverdbegrepet har på den ene siden har vært til støtte for undertrykte grupper, og sees av mange som et begrep i kampen for «det gode». Samtidig ser man at menneskeverdbegrepet også faller sammen med en historie om hvem som regnes som verdige på den ene siden, og dem som ikke er like verdige på den andre. Mennesker vurderes og graderes, de får terningkast eller karakterer. Det endelige kvalitetsstempelet er om elevene blir borgere som bidrar i samfunnet.

Likevel er ikke menneskeverd og verdighet bare honnørord hevet over enhver kritikk. Tvert imot, begrepene viser seg å være stadig mer omdiskutert. De er en het potet i en rekke debatter om etiske spørsmål og kan representere uklarhet i vanskelige moralske, politiske eller juridiske problemstillinger. Dersom skole og samfunn behandler elever og samfunnsborgere forskjellig, kan det være grunn til å reise spørsmål om virkelig menneskeverd og verdighet er begreper som til og med har gått ut på dato. I noen sammenhenger framstår de som tomme ord og som idealer som ikke kan realiseres. Begrepene beskyldes til og med for å være tomme for innhold og ikke anvendbare i møte med nye aktuelle problemstillinger. "The problem is that "dignity" is a squishy subjective notion, hardly up to the heavyweight moral demands assigned to it» (Pinker, 2001, s. 28).

Vår respons er at menneskeverd ikke nødvendigvis behøver å være entydig og klart for å være anvendelig. Kravet om entydighet, eller mangelen på entydighet er ikke i seg selv grunn til å forkaste en verdi. Verdier 
som rettferdighet, likhet, frihet og toleranse er ikke enkle og entydige begreper. Det gjør dem ikke irrelevante. I stedet ser vi menneskeverd og verdighet som viktig å debattere når det gjelder om de er i bruk, og hvordan vi som samfunn tar dem i bruk. Menneskeverd og verdighet har et potensiale som kan generere spørsmål som setter menneskelig eksistens og sameksistens på spissen. Menneskeverd kan sees som et funksjonelt begrep som ansvarliggjør, utvider diskurser og påpeker maktmønstre; for hverandre, og for den verden vi lever i. I stedet for å avskrive begrepet, vil vi i stedet hevde og påpeke at menneskeverd og verdighet er mangfoldige begreper. De kan forstås på ulike måter. Vår oppgave i denne boka er derfor å utforske mangfoldet og undersøke hvilke konsekvenser forståelsen av menneskeverd får i skole og samfunn.

Denne vanskelige oppgaven er det vi har gitt oss i kast med når vi har utfordret fagfolk fra ulike grener av «menneskevitenskapene», som pedagogikk, filosofi, samfunnsfag, religion, norsk og kunst-og håndverk. Når vi primært tar utgangspunkt i skole og utdanning, betyr det ikke at vi ser andre virksomheter som tematiserer menneskeverd som irrelevante. I stedet er hensikten å bringe fram kunnskap og dilemmaer om begrepene menneskeverd og verdighet som også kan utfordre og ha gyldighet for andre fagområder.

I boka tar vi ikke sikte på å «dekke» verdighetsbegrepet eller å argumentere for én tilnærming, snarere tvert imot. Kapitlene i boka vil til dels stå i motsetning til hverandre. Boka ønsker å bringe deskriptive så vel som normative bidrag som peker på og vil kunne utfordre verdigrunnlag og praksiser i skole samfunnsinstitusjoner.

Vi redaktører vil takke forlaget Cappelen Damm og vår trofaste redaktør Mary-Ann Hjemdal sammen med Maria Braadland. Vi vil også takke Universitetet i Sørøst-Norge, og Fakultet for Humaniora, Idretts- og utdanningsvitenskap for økonomisk støtte og god tilrettelegging. Sist, men ikke minst vil vi med dette også takke alle forfatterne i boka for sterkt faglig fellesskap, uvurderlige bidrag og sympatisk tålmodighet i prosessen.

Ådne Valen-Sendstad

Ingrid Christensen

Oslo, 10 desember 2019 



\title{
Introduksjon: Menneskeverd - mangfoldige forståelser for en mangfoldig skole
}

\author{
Ådne Valen-Sendstad \\ Universitetet i Sørøst-Norge \\ Ingrid Reite Christensen \\ Universitetet i Sørøst-Norge
}

\begin{abstract}
This chapter is called "Human dignity - diverse approaches for diversity in school". Human dignity is one of the most important value concepts, as it appears as a common, global value that "everyone" owns - and is yet the source of the most merciless ongoing debates in society. In school, these debates are less in focus. In the formal curriculum and in the educational laws, dignity appears as a repeated basis. Yet, in educational discourse and teaching practices the definitions are vague and seldom concretized. In this chapter, we ask the following: 1) What characterizes different approaches to dignity as a concept? 2) What challenges and possibilities do the different approaches to dignity entail in school?

In this chapter we will therefore aim at presenting different approaches to dignity. We do so by presenting a broad spectrum of approaches to dignity. We argue that dignity might be a diverse concept, and it can be explored as approaches promoting the "dignity of the strong" versus the "dignity of the weak". The different approaches are exemplified with key issues of diversity and inclusion in school. The aim of the chapter is to give an introduction and an overview of diverse approaches to dignity and thus, finding the beginnings of new debates about dignity for a diverse school.
\end{abstract}

Keywords: Human dignity, education, values, diversity, conceptual understanding

Dette kapittelet har vi kalt «Menneskeverd - mangfoldige forståelser for en mangfoldig skole». Vi skal utforske et utvalg av tolkninger av

Sitering av denne artikkelen: Valen-Sendstad, Å. \& Christensen, I. R. (2019). Introduksjon: Menneskeverd mangfoldige forståelser i en mangfoldig skole. I A. Valen-Sendstad \& I. R. Christensen (Red.), Menneskeverd - en utfordring for skole og samfunn (Kap. 1, s. 11-38). Oslo: Cappelen Damm Akademisk. https://doi.org/10.23865/noasp.9o.ch1.

Lisens: CC BY-NC 4.o. 
menneskeverdbegrepet, og drøfte hvorfor disse kan være viktige for en skole som verdsetter mangfold og likeverd. Menneskeverd og verdighet er noen av de viktigste verdibegrepene i samfunnet i dag, og noe som «alle» på sine vis har et eierskap til. Menneskeverd har vært og er en grunnleggende verdi for en rekke samfunnsinstitusjoner blant annet i skolen, som er rammen for denne boken. Menneskeverd berører juridiske, politiske, økonomiske, pedagogiske og moralske avgjørelser.

Formålsparagrafen i Opplæringslova (1998) § 1-1 sier:

Opplæringa skal byggje på grunnleggjande verdiar i kristen og humanistisk arv og tradisjon, slik som respekt for menneskeverdet og naturen, på åndsfridom, nestekjærleik, tilgjeving, likeverd og solidaritet, verdiar som òg kjem til uttrykk i ulike religionar og livssyn og som er forankra i menneskerettane.

Menneskeverd regnes som grunnleggende i synet på barn og ungdom. Begrepet kan gi retning for pedagogiske veivalg og undervisningsmetoder, og står som en garantist for individets rett til utvikling og læring (Løken \& Stubø, 2018). I skolen legges også menneskeverdet til grunn for å fremme verdier og holdninger som forbereder individet for å delta i samfunnet. Skolen er en «verden i miniatyr», en arena som forbereder mennesket for det å leve i samfunnet (Dewey, 1902, s. 18). I lovverket har norsk skole en klar normativ og moralsk oppdragende funksjon, som folkedannende og samfunnsbyggende prosjekt (Kunnskapsdepartementet, 2015, s. 7; Slagstad, 1998, s. 3). Skolen representerer ikke et hvilket som helst samfunnsbyggende prosjekt; den skal bidra til et samfunn som fremmer menneskeverd. Dette stiller eleven og menneskeverd i skolen i søkelyset.

Den nye læreplanen (2020) har viet artikkel 1.1, Overordnet del, til menneskeverdet. Der heter det blant annet:

Skolen skal sørge for at menneskeverdet og de verdiene som støtter opp om det, legges til grunn for opplæringen og hele virksomheten. Formålsparagrafen bygger på menneskeverdets ukrenkelighet og at alle mennesker er like mye verdt, uavhengig av hva som ellers skiller oss. Når lærere viser omsorg for elevene og ser den enkelte, anerkjennes menneskeverdet som en grunnleggende verdi for skolen og samfunnet. Menneskerettighetene har sitt grunnlag i menneskeverdet og er en viktig del av fundamentet for rettsstaten. De bygger på universelle verdier som gjelder for alle uansett hvem de er, hvor de kommer fra, og hvor de befinner seg. 
Læreplanen ser menneskeverdet som grunnleggende, og skolen skal representere likeverd overfor et mangfold av elever. Er da menneskeverd noe som bare «gir seg selv», og har alle en forent forståelse av begrepet? Dette er vi usikre på. På den ene siden kan det tyde på lite debatt om og lite aktiv bruk av menneskeverdsbegrepet i skolen. I Vesterdals (2016) studie av verdiplattform hos lærere i norsk skole beskrives menneskeverd i sammenheng med menneskerettigheter. Disse framstår som idealer som lærere er stolte av og gjerne snakker om. Lærerne i undersøkelsen mener at norsk skole går foran som et godt eksempel, og de hevder at menneskerettighetene brytes sjeldnere i Norge enn $i$ andre land. Samtidig opplyser lærerne at de savner konkrete undervisningsopplegg for å gi en forståelse av menneskeverd og verdighet. Bowie (2017) viser liknende funn i sin studie; menneskeverd er i liten grad anvendt i skolen, både i planarbeid og i undervisning.

Menneskeverd kan framstå som et uklart begrep. Vesterdal (2016) og Bowie (2017) hevder at lærere i liten grad kan beskrive hva menneskeverd betyr og innebærer. Videre viser Tapolas (2011) studie blant svenske lærerutdannere at menneskeverd er vanskelig å skille ut som eget begrep. Menneskeverd knyttes til f.eks. respekt, solidaritet og sosial rettferdighet, men selve innholdet $\mathrm{i}$ menneskeverdsbegrepet synes å være av mindre betydning. Vi kan si at menneskeverd framstår som en mektig diskurs i intensjonene for hva som skal styre skolen, samtidig som det framstår som marginalt i skolens diskurs der man i liten grad kan beskrive innholdet, problematisere eller diskutere hvordan man skal tolke, ivareta og formidle menneskeverdsbegrepet. I så fall er det kanskje ikke gitt at den enkelte lærer kan ta til orde eller stille spørsmål ved begrepet. Menneskeverd representerer en «black box» ${ }^{1}$ - et begrep for noe som er «allment», men som unngår definisjon. Uklarheten om innholdet i menneskeverdbegrepet er en utfordring - både for skolen, og for det samfunnet som skolen fungerer som en aktør for.

Det er betydelig faglig debatt rundt menneskeverdsbegrepet innen juss, filosofi, biologi, medisin, religion, politikk osv. Eldre forstålser av menneskeverd eksisterer samtidig med nyere forståelser. På disse arenaene er menneskeverd som begrep under stadig kritikk og nytolkninger. Studiene

\footnotetext{
1 «Blackbox» refererer ofte til innenfor IKT, der man kan vite om hvilken informasjon man legger inn eller man får ut, men der selve prosessen er ukjent eller holdes konfidensielt. http://www. businessdictionary.com/definition/black-box.html. Lesedato: 10.07.19.
} 
over viser at vi finner lite av denne debatten i skolen. Der hvor lovverk og læreplan i dag presenterer menneskeverd som en plattform, framstår altså begrepet utilnærmelig og uklart. Det er derfor av stor betydning for norsk skole å se nærmere på menneskeverd som begrep. Som Düwell understreker «[M] ost people believed that they knew what human dignity was about, but that this attitude has changed, prompting a call for intellectual study on the topic» (Düwell, 2014, s. 23). Dersom det er slik at utvikling av menneskeverdsbegrepet til dags dato befinner seg utenfor skole og utdanning, vil det være viktig å bevege seg dit debattene er.

I dette kapittelet stiller vi derfor spørsmålet:

Hva kjennetegner ulike tilnorminger til menneskeverdsbegrepet, og hvilke konse-

kvenser kan disse tilnormingene få i skolen?

Hensikten med kapittelet er på den ene siden å gi en innføring og å utforske et mangfold av tilnærminger til menneskeverdsbegrepet, for deretter å drøfte hvilke konsekvenser disse kan få for en skole som skal representere menneskeverd og likeverd overfor et mangfold av elever. Denne innføringen kan forhåpentligvis være en utfordring og et bidrag til en ny, overordnet forståelse av mangfoldet og spenningsfeltet rundt menneskeverdsbegrepet i skolen. Vi tar utgangspunkt i kunnskap fra flere fagområder som juss, filosofi, religion og til dels økologi. ${ }^{2}$ Menneskeverd representerer ikke bare ord og språk, det representerer også merkesteiner og betingelser for hvordan menneskeverd praktiseres og formidles, noe som også får konsekvenser for skolen. ${ }^{3}$

For å undersøke hva som kjennetegner ulike tilnærminger til menneskeverdsbegrepet legger vi til grunn noen normative antakelser. For

2 Det ville også vært aktuelt å hente debatter fra langt flere arenaer, som økonomi, naturvern og medisin. Avgrensningen her er foretatt på et pragmatisk grunnlag, og ut fra andre disipliner som regnes med i humaniorafeltet. Skillet mellom «myke» humaniora og «harde» naturvitenskap, er imidlertid sterkt debattert (se f. eks. Barad, 2007; Haraway, 2008; Knorr Cetina, 1988; Latour, 1987).

3 Vi vil understreke at vi først og fremst beskriver forståelser og bruk av begrepet menneskeverd. Å se på hvordan menneskeverdsbegrepet er i bruk, betyr at vi ikke skiller mellom fenomenet menneskeverd og språk for menneskeverd. I henhold til sosialkonstruktivistiske tilnærminger er språk og fenomen dynamiske helheter. Derfor vil menneskeverd som fenomen og våre begreper for det henge uløselig sammen (Laclau \& Mouffe, 2002, s. 21). Imidlertid har vi ulike analytiske nivåer, der man kan skille mellom å undersøke hva menneskeverd er, og å undersøke diskurser og tilnærminger til menneskeverd på et metaplan. 
det første hevder vi at menneskeverd representerer et mangfold av tilnærminger og anvendelsesområder i samfunnet. ${ }^{4}$ Dette innebærer ikke at vi på noen måte gir en komplett redegjørelse for begrepet menneskeverd. ${ }^{5}$ Med rammene for kapitlet er det ikke plass for en dybdeanalyse av de enkelte teoriene vi presenterer. Likeledes er det ulike måter å beskrive menneskelig mangfold og likeverd på tvers av elevenes ulike bakgrunn og forutsetninger. Noen vil fremheve menneskets unike egenart, og det som gjør mennesket særlig opphøyd og unikt. Disse antar at det er nettopp menneskets «sterke» sider som skal framheves og beskyttes. På den annen side vil mange ta utgangspunkt i det motsatte - nemlig at det er menneskets sårbarhet, ulike behov og mangfold som i stedet bør være i søkelyset for menneskeverd. Menneskeverd er et begrep som skapes og defineres i ulike relasjoner og ulike situasjoner, og som kan trues, eller opphøre. Dette kan vi kalle en form for «svakere» forståelse av menneskeverdet. De analytiske kategoriene «sterke»/«svake» tilnærminger til menneskeverd danner grunnlag for vårt argument i dette kapittelet: Menneskeverd er et mangfoldig begrep, og kan utforskes som tilnærminger som fremmer «det sterke menneskeverd» versus «det svake menneskeverd». Til tross for at også disse to kategoriene av forståelser av menneskeverd representerer et spekter av ulike posisjoner, vil denne inndelingen kunne nøre opp om kritisk debatt også i skolen om hva som kjennetegner og hva de ulike tilnærminger til menneskeverd innebærer for skolen. Å se menneskeverd som en «sterk» kvalitet i motsetning til en «svak», sikter også mot å skissere et teoretisk bidrag til menneskeverd

4 Når vi beskriver tilnærminger til menneskeverd i samfunnet, tar vi utgangspunkt i vestlige tilnærminger til menneskeverd. Dette er sentralt, da norske læreplaner og norsk skole i stor grad bygger på vestlig tankegods i sine beskrivelser av menneskeverd og menneskerettigheter. Imidlertid mener vi at det å beskrive ulike forståelser av menneskeverd kan bidra til å åpne opp et tilsynelatende enhetlig syn på det vestlige menneskeverdsbegrepet, og slik også danne grunnlag for andre, ikke-vestlige forståelser.

5 Vi er klar over at vi utelater den delen av debatten som mener menneskeverdsbegrepet er ubrukelig og utdatert. Det beskyldes for å være unyttig og bør kastes på den idehistoriske skraphaugen: «Dignity is a useless concept in medical ethics and can be eliminated without any loss of content» (Macklin, 2003; s. 1420). Begrepet beskyldes for å være tomt for innhold og er ikke anvendbart i møte med nye aktuelle problemstillinger innen biologi og medisin. Det hevdes at begrepet ikke leverer. "The problem is that 'dignity' is a squishy subjective notion, hardly up to the heavyweight moral demands assigned to it» (Pinker, 2001, s. 28). Dette er selvsagt viktige synspunkter, men på grunn av omfanget i kapittelet har vi utelatt det. 
som begrep. Avslutningsvis vil vi drøfte hvilke konsekvenser de ulike tilnærmingene til menneskeverdsbegrepet kan få for samfunn og skole. ${ }^{6}$

\section{Mangfoldet: mellom det «sterke» og «svake» menneskeverdet}

Når man skal gi en oversikt over menneskeverdsbegrepets tolkninger vil man kunne skille mellom «eldre» og «nyere» forståelser, eller foreta en slags kronologisk oversikt over utviklingen av begrepet (Michael Rosen, 2012). Samtidig er det slik at både eldre og nyere tilnærminger til menneskeverd eksisterer side om side. Begrepet er på en måte gammelt, men det er først etter Menneskerettighetserklæringen av 1948 at det har fått den framskutte posisjonen som det har i dag. Menneskerettighetshistorikere peker på at de som konstruerte rettighetene i stor grad bygde på Kant og kristen tradisjon (Morsink, 1999, 2009; Moyn, 2015). Flere, blant annet filosofer og jurister, har ikke vært tilfredse med kantianske og kristne tolkninger og har utviklet alternative forståelser av verdighetsbegrepet, de fleste av dem etter 1948. De fleste av det vi kaller «sterke» tolkninger er eldre, mens de fleste «svake» er av nyere dato.

\section{«Sterke» forståelser av menneskeverd}

En betydelig del av tolkningene av menneskeverdsbegrepet kjennetegnes av det som kalles for klassiske eller etablerte begrepsforståelser. Disse forståelsene har røtter i metafysikk og naturrettstenkning. Slike forståelser ser etter hva mennesker til ulike tider har til felles, en essens og etter en kjerne, en rest av noe metafysisk i mennesket. Flere av disse mener det finnes naturlover, «unwritten and unchangable laws» (Maritain, 1952, s. 77).

6 Når vi beskriver disse tilnærmingene til menneskeverd, vil vi behandle menneskeverd og verdighet side om side. I dette kapittelet anvender vi primært menneskeverd. Imidlertid er menneskeverd knyttet til begrepet verdighet. På engelsk er «human dignity» og «dignity» gjennomgående begreper som anvendes med overlappende betydning. Samtidig kan menneskeverd og verdighet ha noe ulike valører. Menneskeverd kan knyttes opp mot både det å begrunne menneskeverdighet på den ene siden, mens verdighet kan peke mot praksis og det å leve et liv i verdighet. Bruken av menneskeverd og verdighet har også sammenheng med hvilke fagtradisjoner vi knytter oss opp mot, som i denne boka er vestlig litteratur. 
Dette innebærer for mennesket en naturgitt status som opphøyd over andre vesener. Under denne gruppen regner vi kristne, stoiske, kantianske og nyaristoteliske tolkninger. Dette ser vi som en form for «sterke» forståelser av menneskeverd. Hva etablerte forståelser innebærer, og hvorfor vi kaller dem «sterke» tilnærminger, skal vi se nærmere på.

\section{Mennesket som skapt i Guds bilde}

I historien har det universelle ved mennesket hatt en teologisk og guddommelig forankring. Mange går tilbake til i kristne ideer når man skal beskrive tidlige forståelser av menneskeverd og verdighet i vestlig sammenheng (Perry, 2007). Fra kristent teologisk hold har det vært vanlig å begrunne menneskeverdet med skapelsesfortellingen i Bibelen. Dette til tross for at begrepet menneskeverd faktisk ikke benyttes eksplisitt i Bibelen. Første gang en kristen teolog anvender verdighetsbegrepet er pave Leo I (440-461 e.Kr) (Sensen, 2011a, s. 78). Menneskeverdet tolkes og forankres i fortellingen om at mennesket er skapt av Gud i en av Bibelens skapelsesfortellinger. Mennesket er skapt med en likhet til Gud, dette beskrives som «imago Dei»:

26 Gud sa: «La oss lage mennesker i vårt bilde, så de ligner oss! De skal råde over fiskene i havet og fuglene under himmelen, over feet og alle ville dyr og alt krypet som det kryr av på jorden.» $\underline{27}$ Og Gud skapte mennesket i sitt bilde, i Guds bilde skapte han det, som mann og kvinne skapte han dem. (1 Mos 1:26f)

I kirkehistorien er det flere tolkninger av «imago Dei» (Hollenbach, 2014; Loughlin, 2016). Mennesket skapt i Guds bilde er det som gir mennesket dets verdighet. Det innebærer at fordi mennesker har noe som ligner på Gud, står de likt som mennesker overfor Gud, men ikke nødvendigvis overfor hverandre eller i samfunnet (Patel, 2005). Når mennesket er skapt i Guds bilde får det samtidig et mandat. Mennesket får i oppdrag å leve opp til denne likheten, streve etter det verdige, i denne sammenhengen leve opp til Guds vilje, forvalte og være herre over andre arter og vekster på jorden.

I verdighetsbegrepets historie står rennesansehumanisten Pico della Mirandola (1998) sentralt med boken «On the dignity of man». Mirandola knytter mennekets verdighet til Gud, som har gitt mennesket frihet til 
selv å designe og styre over sitt eget liv: «O great liberality of God the Father! O great and wonderful happiness of man. It is given him to have that which he chooses and to be that which he wills» (1998, (1463-1494), s. 5) Han forskyver interessen for og begrunnelsen av menneskeverdet. For ham blir det sentrale at mennesket kan planlegge og selv bestemme hvordan det vil leve. I menneskets frihet ligger verdighet og menneskeverd.

I kjølvannet av Mirandola kan man se at slike kristne tolkninger av verdighetsbegrepet tar utgangspunkt i en «sterk» forståelse av menneskeverd. En «sterk» forståelse innebærer at mennesket har verdigheten gitt fra Gud som har utrustet mennesket med kvaliteter som fornuft og frihet. På grunn av disse kvalitetene står mennesket over alt annet liv. Det å ha verdighet er en særstilling i naturen, løftet over andre biologiske arter.

I slike kristne tolkningene av menneskeverdet er verdigheten på lån fra Gud. Mennesket er tildelt den statusen. Samtidig er den metafysiske tanken om iboende verdighet ikke entydig i kristne tekster om menneskeverd. Menneskeverdet er gjenstand for teologiske diskusjoner. Det er ikke vår intensjon eller oppgave å delta i den samtalen, men siden de kristne tolkningene er og har vært så innflytelsesrike, er de relevante for denne presentasjonen og norsk skole. Et av problemene i en pluralistisk og sekularisert verden er i hvilken grad den kristne fortellingen er relevant for dem som ikke er del av de kristne kirkene eller tror på en skaper (Ignatieff, 2001). I en norsk skolesammenheng mener vi at den kristne fortellingen hører med som en tolkning av verdighetsbegrepet. Samtidig kan den ikke stå som en normerende allmenn fortelling eller grunnlag for menneskeverdet i dagens samfunn. Like fullt har den kristne tradisjon hatt og har en stor innflytelse også på sekulære tolkninger av menneskeverdet, ikke minst i menneskerettighetene (Moyn, 2015). Menneskeverdet er imidlertid i rettighetene med overlegg blitt gjort religionsnøytralt for å gjøre dem mer inkluderende og tilgjengelige for andre religiøse og sekulære tolkninger (Maritain, 1948).

\section{Orden og dyd}

Den filosofiske bruken av verdighetsbegrepet har flere røtter (Michael Rosen, 2012). En viktig kilde kan sees i kristendommen, mens vi også kan finne røtter til forståelse av menneskeverd i antikken og hos stoikerne, og da spesielt hos den romerske politikeren og filosofen Cicero. 
(Micheal Rosen, 2012). Cicero representerer et eksempel på en «klassisk» tilnærming til menneskeverd. For Cicero var verdighet knyttet til menneskets rasjonalitet. Rasjonaliteten er det som skiller mennesker fra dyr. Et liv i verdighet innebar måter å leve på, knyttet til en verdig livsform. Man skulle vise seg sin status verdig gjennom å realisere dyder. Cicero mente at det var en naturgitt hensiktsmessighet, teleologi, en retning på hvordan mennesker skal leve for å virkeliggjøre verdigheten (Sensen, 2011a). Med Cicero ble verdighet en status og et dydsbegrep, samtidig som det gjenspeilte det å leve opp til en slags overordnet, metafysisk bestemt virkelighet, en naturlov, for mennesker.

Et eksempel fra vår tid som ligner Ciceros forståelse kan være Frankrikes lov fra 2010 som forbyr heldekkende klesplagg. Denne loven ble begrunnet med verdighetsbegrepet. Det ble påstått at heldekkende klesplagg, les niqab og burka, bryter med den franske republikkens forståelse av verdighet. Verdighet i den franske tolkningen forventer at man følger et sett av normer og væremåter definert av republikken (Robcis, 2016, s. 326). Liknende eksempler finnes også i lovgivning og forbud mot niqab i norsk skole (Köhler-Olsen, 2010). For Cicero var det en plikt å leve opp til den statusen mennesket hadde som rasjonelle vesener og leve ut sine plikter og dyder, sin status, som var gitt i naturen. I Frankrike er de i eksemplet over gitt av staten.

Vekten ifølge en dydsforståelse er selv å leve opp til verdigheten. En kritikk av denne forståelsen av verdighet er at den kan være kynisk (Nussbaum, 2008b). Verdighet har noe med adferd å gjøre, men i denne tolkningen leder den ikke nødvendigvis til moralsk ansvar for andres liv. Den bygger på en form for individuelt ansvar overfor en overordnet, forhåndsbestemt orden. Til tross for at den klassiske tilnærmingen til menneskeverd er ulik den kristne, skapt i Guds bilde, vil man fremdeles ha å gjøre med en orden, en form for ytre autoritet.

\section{Iboende verdighet, rasjonalitet, moral og autonomi}

Om vi gjør et sprang fram til opplysningstid, blir autonomi og rasjonalitet sentrale ideer. Immanuel Kant har hatt og har fremdeles en stor innflytelse på betydelige deler av diskursen, jf. Habermas (Habermas, 2010), Gewirth (Gewirth, 1996) og Sensen (Sensen, 2011b). Kant (1785/2012) leverer hva vi 
i dette kapittelet kaller en «sterk» forståelse av verdighetsbegrepet, som innebærer at det er noe iboende ved mennesket. I et meget berømt sitat skiller han mellom tre former for verdi: noe har en markedsverdi, annet har er nytelses- eller opplevelsesverdi. Den tredje betydningen er det som har verdi i seg selv. Mennesket har en slik verdi i seg selv. Det har ikke markeds- eller nytteverdi, men en verdi i seg selv, en iboende verdi:

Whatever has reference to general human inclinations and needs has a market price; whatever presupposing any need, accords with a certain taste, i.e., a delight in the mere unpurposive play of our mental powers, has an affective price; but that which constitutes the condition under which alone something can be a value in itself has not merely a relative worth, i.e., a price, but has an intrinsic worth, i.e., dignity. (Kant, 1785/2012;art 435)

Kant er imidlertid ambivalent. På et nivå har mennesket en iboende verdi, nærmest en metafysisk dimensjon. På et annet nivå har mennesket verdighet på grunn av sin rasjonalitet, moral og autonomi. Menneskets verdighet fundamenteres på den måten i menneskets mulighet for å kunne utvikle morallovene som for å være lover må kunne universelle. Menneskets verdighet henger på dets moralske kapasitet.

Koblingen mellom verdighet og moral framkommer også på en annen måte hos Kant. Når individet erkjenner sin egen verdi, må det samtidig anerkjenne at ethvert annet menneske har den samme verdigheten. Utvidet dreier det seg om menneskehetens verdighet. Implikasjonene gir ifølge Kant mennesker et moralsk imperativ til å ta ansvar for å behandle andre i tråd med verdigheten, og ikke behandle andre som brikker i et spill om nytte eller konsekvenser. Menneskets verdighet innebærer at man respekterer sin egen verdighet, men også andres, utvidet til menneskehetens verdighet. Kant formulerer det slik:

... humanity itself is a dignity; for a human being cannot be used merely as a means by any human being (either by others or even by himself) but must always be used at the same time as an end. It is just in this that his dignity consists, by which he raises himself above all other beings in the world that are not human beings and yet can be used, and so over all things. But just as he cannot give himself away for any price (This would conflict with his duty of 
self-esteem), so neither can he act contrary to the equally necessary self-esteem of others, as human beings, that is, he is under obligation to acknowledge, in a practical way, the dignity of humanity in every other human being. Hence there rest on him a duty regarding the respect that must be shown to every other human being. (Kant, 1797/2017, s. 225)

I likhet med Cicero og den kristne tradisjonen setter Kant mennesket i en særstilling. Verdigheten skiller mennesket fra dyr, og setter mennesket over andre arter. En svakhet med Kants tolkning er at rasjonaliteten blir så vidt avgjørende; det blir et spørsmål om verdigheten til de som ikke er i stand til å utvikle universell moral. I Kants forståelse er det flere elementer, selvrespekt og likeverd, men det er også en metafysisk rest og en tung vektlegging på rasjonalitet. Kant er helt sentral i diskusjonen om verdighet, og har fått sterkt gjennomslag (McCrudden, 2008). Samtidig er det ikke noen allmenn enighet om hans forståelse - og i alle fall ikke til hva som eventuelt er iboende ved mennesket.

\section{Intuisjon og kapasiteter}

Et alternativ til de tolkningene vi så langt har presentert, er Nussbaums tolkning av verdighet med et fokus på menneskelige psykologiske og fysiske behov. Det er en form for moderne naturrett og nyaristotelisk filosofi, men ifølge Nussbaum selv uten metafysikk (2008b, s. 4). Hun gir ikke en definisjon av menneskeverdet, men hun hevder at det bygger på en intuisjon. Imidlertid er det en utfordring å få tak på hva denne intuisjonen består i. På den ene siden sier hun: «dignity is an intuitive notion that is by no means utterly clear» (Nussbaum, 2011, s. 29). Samtidig definerer hun verdighet som «a type of worth in the human being ... that exists and remains even when the world has done its worst» (Nussbaum, 2008a, s. 200). Det er noe ved mennesket som utløser intuisjonen om menneskets verdighet, men det er ikke selvinnlysende eller klart hva det er.

Nussbaums verdighetsbegrep bygger ifølge Claassen på tre begreper. Det ene er respekt: «dignity demands respect from others» (Claassen, 2014, s. 242. Det andre gjelder aktivitet, knyttet til at mennesker kan være aktive og legge planer for sine liv. Til slutt er verdighet relatert til likhet, at alle 
skal ha mulighetene til gode liv. Hun kobler verdighet med menneskelige biologiske behov og anlegg. Disse behovene og anleggene kaller hun for kapasiteter («capabilities»). Nussbaum definerer disse kapasitetene som «the innate equipment of individuals that is the necessary basis for developing the more advanced capabilities, and a ground for moral concern» (Nussbaum, 2000, s. 84). Disse kapasitetene er biologisk og sosialt betinget.

Nussbaum hevder at verdighet henger på ti kapasiteter som er utgangspunkt for et godt liv. Disse er liv, helse, kroppslig integritet, sansing/forestillinger/tanker, følelser, å legge livsplaner, knytte bånd til andre mennesker, vennskap med dyr, lek og medbestemmelse/kontroll over egen eiendom og politikk (Nussbaum, 2011, s. 33f). Der hvor Kant primært er opptatt av rasjonalitet og moral som «iboende» kvaliteter ved mennesket, vil Nussbaum utvide og si at det er flere kvaliteter som kan være avgjørende for et liv i verdighet. Hun er opptatt av at verdighet gjelder mennesker i sårbare livsfaser som barndom og alderdom, og for mennesker med nedsatte funksjonsevner samt utviklingshemming. Disse trenger støtte fra fellesskapet for å kunne leve verdige liv. Respekt for menneskeverd er ikke bare «lip service» (Nussbaum, 2008b, s. 4). Nussbaum inntar også en annen posisjon enn de vi så langt har drøftet, med tanke på hun også snakker om dyrs verdighet (Nussbaum, 2008b, s. 6). Nussbaum beskriver en rekke fellestrekk og noe allmennmenneskelig, en form for menneskelig essens. Dette gjør at hun representerer en form for «sterk» tilnærming til menneskeverdet.

De «sterke» forståelsene av menneskeverdet er for flere helt avgjørende for at begrepet skal ha mening. «Sterke» tolkninger innebærer at mennesket har verdi fordi mennesker har unike kvaliteter eller noe som er iboende. Det gjelder alle, det er universelt. Denne sterke, tydelige og essensielle forståelsen kan imidlertid kritiseres.

Den første kritikken av disse tolkningene kan handle om det å søke en slags metafysisk kjerne i mennesket. I det foregående har denne kjernen bestått i noe ubestemmelig, noe guddommelig, i dyder, i rasjonelle evner, eller kapasiteter. Hver for seg har disse blitt satt spørsmål ved, ikke minst i den senere diskusjonen om menneskeverdet. Det er uenighet om hva denne kjernen så skal bestå i. Videre kan man drøfte mennesket ut fra kapasiteter, og hvilke kapasiteter ved mennesket som gjelder alle. Er de universelle, uavhengig av kultur? Hvordan disse kapasitetene rangeres? 
Hvor mye rasjonalitet er nødvendige for reelt å ha verdighet? Hvor går grensen mellom et liv i verdighet og et liv som faller utenfor? Eller er menneskelighet en moralsk dyd å leve opp til - og hva skal til for å leve opp til disse? Dette er svært grunnleggende spørsmål. Utfordringen er om vi med disse spørsmålene fremdeles kan holde fast på en «kjerne», et gyldig kriterium for menneskeverd. Dette kan også få konsekvenser for hvilken forståelse vi har av elevene i skolen. De «sterke» tolkningene utgir seg for å være inkluderende, men er de faktisk også ekskluderende? Disse spørsmålene utgjør kritikken av typisk «sterke» tilnærminger. Samtidig vil vi si at det kan være problematisk å presentere dem som enerådende tolkinger av menneskeverdsbegrepet. I det neste skal vi se om det kan finnes alternative forståelser av menneskeverd som begrep, og det vi vil kalle «svake» tilnærminger til menneskeverd.

\section{«Svake» tolkninger av menneskeverdet}

Flere tilnærminger til menneskeverd ser ikke menneskeverdet som iboende eller metafysisk. Menneskets verdighet blir sett nedenfra, fra mennesket selv. Det er vi som gir oss selv statusen, sier Kateb (2011). Han sammenligner mennesker og andre arter - og etterlater mennesket øverst på tronen, inntil noe bedre overgår dagens menneske. I likhet med Kateb mener Kolnai (1995) at verdighet ikke beskriver hva mennesket er, men at det er noe vi tilskriver mennesker. "The concept of 'Human Dignity' is properly and principally ascriptive rather than either descriptive or prescriptive» (Kolnai, 1995, s. 61). Et grunnleggende trekk ved det vi kaller «svake» tilnærminger til menneskeverd er at de erkjenner at forståelsen av menneskeverdet er utviklet og påvirket i et samspill med kontekst og historien.

\section{Verdighet - et politisk og juridisk endringsbegrep}

Hva det innebærer å tolke og utvikle menneskeverdsbegrepet blir utdypet av blant annet Catherine Dupré (2015). Hun argumenterer for at menneskeverdet er et begrep som i en politisk juridisk sammenheng har inspirert, ledet og gitt retning på endringer av samfunn. Hun mener at verdighet er et grunnbegrep i europeisk konstitusjonell sammenheng, 
og at det har vært retningsbestemmende for demokratiers utvikling i Europa. Begrepet har blitt et fundamentalt begrep i flere konstitusjoner, særlig kjent er artikkel 1 i den tyske grunnloven fra 1949:

Die Würde des Menschen ist unantastbar. Sie zu achten und zu schützen ist Verpflichtung aller staatlichen Gewalt.

[Menneskeverdet er ukrenkelig. All statsmyndighet er forpliktet til å respektere og verne om menneskeverdet.]

Her beskrives menneskeverdet som en grunnverdi, men også som en grunnrettighet. Den slår fast hva loven skal bygges på, og hva tyske borgere har rett til. Imidlertid viser Dupré hvordan disse rettighetene og lovbestemmelsene utformes i flere europeiske land fra etterkrigstiden og framover. Hun argumenterer for at verdighet og menneskeverd som begreper stadig er i endring, blant annet som drivkraft i utvikling av arbeideres og sosiale rettigheter (Dupré, 2015, s. 134, 138). Ut fra dette trekker hun to kontroversielle slutninger: Menneskeverd som begrep har ikke et fast innhold. Det anvendes på nye områder og fylles med nytt innhold i møte med nye behov. Menneskeverdet har det hun kaller et stort «symbolsk overskudd» (Dupré, 2015, s. 125), noe som innebærer at menneskeverdet er en pådriver for forandring. Det er særlig utsatte grupper som har blitt løftet og inkludert. Tolkningene og utviklingene av menneskeverdet fylles med nytt innhold gjennom demokratiske prosesser. Verdighet blir et resultat av kompromisser, og den blir anvendt i konkrete samfunnsspørsmål. På denne måten ser vi ikke en forhåndsbestemt menneskeverdsforståelse, men forståelsens retning fylles med innhold bestemt av samhandling og konkrete historiske utfordringer.

I skolen er retten til tilpasset opplæring til en mangfoldig elevgruppe svært omdiskutert. Det er et interessant eksempel på en juridisk bestemmelse for skolen. I Opplæringslova $\$ 1-3$ gis alle elever retten til individuelt tilpasset opplæring. Til tross for at tilpasset opplæring er et bærende prinsipp for skolen, er det ulike fortolkninger av hvordan «tilpasset» skal bety. Dette er en kilde til store diskusjoner om både organisering, metoder og grunnlagstenkning i skolen. På den ene siden ble det i 1996 presisert av Kirke-, utdannings- og forskningsdepartementet at «individuell tilpassing er nødvendig for at alle elevar skal få eit likeverdig tilbod» (KUF, 1996, s. 58). På den annen 
side sies det nå både i Kunnskapsdepartement og Utdanningsdirektoratet at tilpasset opplæring «... er ingen individuell rett, men skal skje gjennom variasjon og tilpasninger til mangfoldet i elevgruppen innenfor fellesskapet.» (Kunnskapsdepartementet, 2018, [original utheving])? Forståelsen av elevers rettigheter ser derfor ut til å kunne endre seg markant, til tross for at begge hevder å fremme tilpasset opplæring.

Eksemplet viser politiske og juridiske vurderinger som angår elevers muligheter i skolen. Menneskeverdet er ikke anvendt i diskusjonen. Likevel kan det i lys av Duprés tolkning vise hvordan menneskeverdet og likeverdet hos den enkelte tolkes vidt forskjellig, og hvordan dette endrer seg. Med andre ord, å ivareta den enkelte eleven synes ikke å være gitt som en individuell egenskap.

\section{Rang og status - verdighet blir likeverd}

En annen tilnærming ser verdighet som det å ivareta rang og status. Jeremy Waldron (2012) beskriver verdighet som et rang- og statusbegrep, men hevder at også rang og status endrer seg. Han analyserer derfor den historiske utviklingen begrepet har gjennomgått. Nobiliteter hadde i førmoderne tid en verdighet knyttet til posisjoner. Det var knyttet privilegier og rettigheter til titler, embeter og andre sentrale sosiale posisjoner. Denne oppfattelsen av verdighet knyttet til rang ble endret i moderniteten (Waldron, 2012, s. 15). Det som i historien har vært forbeholdt de privilegerte grupper blir ifølge Waldron transformert. Ved innføringen av verdighet som en universell status ble verdighetsbegrepet snudd på hodet. Fra å være for en elite omdannes det til å gjelde alle; det skjedde en «transvaluation» (Waldron, 2012, s. 32), en transformasjon av verdighet. En verdighet som ifølge Waldron (2017) i dag skal tildeles alle likt.

Waldrons rang- og statusforståelse av menneskeverd er en utpreget «svak» forståelse. Waldron bygger ikke på metafysikk eller sterke sider ved mennesket: «the modern notion of human dignity involves an upwards equalization of rank, so that we now try to accord to every human being something of the dignity, rank and expectation of respect that was formerly 
accorded to nobility» (Waldron, 2012, s. 33). Samtidig påpeker han at menneskeverd og verdighet formidler viktige visjoner som aktivt må sikres i lover og menneskerettigheter. Waldrons argument er at menneskeverdet er et resultat av en historisk utvikling i Vesten - som har endt opp i en idé om likeverd. I menneskerettighetene er det likeverd som ligger til grunn. Det kan stilles spørsmål om det er reelt likeverd som kjennetegner samfunnet.

Et eksempel på denne tilnærmingen til verdighet i skolen kan være den norske lovgivningen overfor elever med særskilte behov i Opplæringslova $\$$ 5-1. Hensikten bak lovgivningen er å ivareta hver enkelt elevs behov uavhengig av evner og forutsetninger. Dette kan illustrere en form for «svak» tilnærming til verdighet, der opplæring skal gis til et mangfold av elever og ikke bare fremheve elever som allerede ofte kalles sterke. Samtidig ser man i praksis en motstridende diskurs. Hensikten med spesialpedagogisk hjelp beskrives som å «avhjelpe vansker på et tidlig tidspunkt» (Utdanningsdirektoratet, 2017). ${ }^{8}$ Dette innebærer at ulike forutsetninger og vansker ikke bare skal imøtekommes for elevene der de er, men at de skal avhjelpes sine vansker og "heves» mot en standard og et bilde på «den ideelle eleven». Der altså hensiktene er likeverd, kan man jamfør Waldron også se menneskeverd som en status og en standard, som i praksis ofte ikke er gitt.

\section{Verdighet og sårbarhet}

Eksistensialisten Gabriel Marcel (1963) understreker at verdighet ikke bygger på menneskelig kvalifikasjoner eller kompetanse: «Dignity must be sought at the antipodes of pretention and rather on the side of weakness» (Marcel, 1963, s. 134). Han forankrer menneskets verdighet i menneskets sårbarhet og dødelighet. I møte med tilstanden å ikke være, altså døden, framkommer livets verdi. Menneskeverdet er verdien av det å eksistere. Når verdighet bygges opp rundt storhet og prangende egenskaper kan det lede til undertrykkelser, ifølge Marcel. I stedet må man erkjenne at menneskelivets begrensninger og korte varighet er det som gir livet dets betydning. Menneskeverdet er slik sett en reaksjon på livets skjørhet.

8 https://www.udir.no/laring-og-trivsel/sarskilte-behov/spesialpedagogisk-hjelp/Spesialpedagogisk-hjelp/Retten/formal/. Hentet: 20.10.19. 
Virginia Mantouvalou (2011), Emmanuel Levinas (1969/2007) og Axel Honneth (1995) beskriver denne reaksjonen videre. Møter med mennesker som befinner seg i sårbare situasjoner kan få fram menneskeverdet. Det å erfare mennesker som holdes nede, undertrykkes og lider kan skape en reaksjon på mangelen av verdighet som de befinner seg i. «A life in desperate need is a life in which a person lacks the essentials to live in dignity. A person's dignity is respected when others are not permitted to treat her in a degrading and unfair manner»(Mantouvalou, 2011, s. 99). Verdighet er her forankret i en uro og en medfølelse som reaksjon på møter med mennesker som er krenket. Med andre ord, verdighet er noe som gis. Filosofen Levinas (1969/2007) tolker den moralske appellen som et imperativ som kommer fra den andre, fra den andres blikk og sårbarhet. For Levinas er den andre et konkret menneske, ikke et generelt abstrakt menneske.

I skolesammenheng kan menneskeverd i følge et slikt syn si noe om relasjonen mellom lærere og elever. Verdighet handler mindre om hvor faglig sterk eller svak en elev måtte være. Verdighet oppstår i lærerens møte med eleven; hvordan læreren oppfatter de ulike elevenes behov, ser deres sårbarhet og styrker og kan kommunisere med dem utfra deres egne behov. Disse tolkningene av verdighetsbegrepet kobler begrepet til solidaritet, til det å se og bli utfordret av andres krenkelser, men også til å vektlegge at livet i seg selv er verdifullt, uavhengig av prestasjon, suksess, grad av veltilpassethet eller framtidige karrierer.

En slik forståelse rammer menneskeverdet inn på en annen måte enn de «sterke» fortolkningene vi presenterte over. Menneskeverdighet forankres nedenfra, i relasjoner og er noe som gis. Det er nok å være menneske. Man kobler ikke verdigheten opp mot kapasiteter, rasjonalitet, dyder eller ferdigheter. Den moralske appellen kommer fra livet som begrenset, eller den trenger seg på i møte med liv levd i uverdighet. Verdighet er noe som gis. Det er det konkrete og unike ved det enkelte mennesket som verdsettes.

\section{Menneskeverd - i menneskets eget bilde}

Hvordan oppnår man så verdighet i relasjoner? Svaret på det er ifølge Avishai Margalit (2011) ved respektfull handling mellom mennesker. Margalit gjør noe interessant med den jødisk-kristne tanken om mennesket 
som skapt i Guds bilde. Han sekulariserer og humaniserer denne tanken ved å si at mennesker står som «bilder av mennesket» overfor hverandre. "The idea of horizontal respect is that each human being, no matter of what shape or color or age, can stand in an iconic relation to the rest of humanity» (Margalit, 2011, s. 119). Ethvert menneske er et menneske, enten det har gjort gode eller dårlige ting, og uansett evner og anlegg. Det er mennesker som gir verdighet til hverandre.

Margalits verdighetsbegrep er koblet til selvrespekt. «Dignity is the representation of self-respect» (Margalit, 1998, s. 52). Den får man gjennom tilhørighet til en gruppe; fra å være med i et fellesskap. Han sammenligner det med det å være irsk. Det vil medføre en stolthet, selvfølelse og selvrespekt som irsk. Ikke fordi man er en fremragende representant, men enkelt og greit fordi man er irsk. Dette utvider han til hele menneskeheten. Dette er ikke en form for felles «essens» for alle mennesker. «Self-respect is the attitude persons have to the fact of their being human» (Margalit, 1998; s. 51). Denne relasjonen er framtredende for Margalit, som er særlig opptatt av forholdet mellom ydmykelse og verdighet. Ydmykelse er å bli devaluert og ekskludert. Verdighet er for Margalit ikke iboende; det er heller ikke basert på kvalifikasjoner og idealer som tilhører en samfunnsorden. I stedet er det en verdighet som konstitueres og skapes i og gjennom relasjoner med andre.

I Margalits tolkning er relasjoner og anerkjennelse avgjørende for menneskeverdet; det er et relasjonelt begrep. Han er opptatt av et anstendig samfunn hvor man ikke ydmyker eller krenker hverandre. I hans forståelse kan man gi, men også ta fra andre verdigheten gjennom hvordan vi forholder oss til andre. I hvilken grad tas verdighet fra elever i skolen, gjennom mobbing men også gjennom nedverdigende behandling $\mathrm{i}$ undervisningssammenheng. For Margalit er ydmykelse å bli behandlet som mindre enn det man er. Dette angår blant annet hvordan man kommuniserer og forholder seg til elever og hverandre i skolens hverdag.

\section{Verdighet - mellom konstruksjon og økologi}

En tilnærming til menneskeverdsbegrepet ser altså på menneskeverd som noe relasjonelt, noe som krever handling. Spørsmålet er om dette er noe 
som bare innebærer relasjoner mellom mennesker. Verdighet kan også defineres ut fra det som omslutter mennesket, og i handlinger og interaksjoner. Det kan beskrives som en slags «økologisk» tilnærming. Mennesket framstår som én blant flere arter. Dette representerer et dypt og gjennomgripende brudd med tanken om mennesket opphøyd som Guds ypperste skapning eller som opphøyd i kraft av sin rasjonalitet. Samfunnsdebattanten Yuval Noah Harari sier følgende om menneskerettighetsdoktrinen: «Homo Sapiens have no natural rights» (Harari, 2018, s. 5). Ifølge et slikt syn eksisterer mennesker bare i historiene mennesker finner på og forteller hverandre. Disse historiene blir holdt i hevd som et selvinnlysende dogme under kampen mot religiøse fordommer og eneveldige styrer (Harari, 2018 s. 218). Det er altså mennesket som i språket gir hverandre privilegier.

Det er ikke bare menneskelige ideer og språk som danner fundament for menneskeverd. Donna Haraway (Haraway, 2008) og Karen Barad (2012) peker på at menneskeverd også må ses i lys av materielle og fysiske betingelser. Haraway viser til at 90\% av det menneskelige cellematerialet også deles med andre arter. Slik sett er mennesket «av verden»: «I am a creature of the mud, not the sky» (Haraway, 2008, s. 3-4). Hun sier også at verden er konstituert i intra- og interaksjon (Haraway, 2008., s. 4). Når vi samhandler, er det ikke alltid enkelt å si hva som utgjør objekt og subjekt. Dette innebærer at mennesket skapes og skaper hverandre kontinuerlig. Det å eksistere er et resultat ulike møter med hverandre og av det å være i samhandling med verden og hverandre: «To be one is always to become with many» (Haraway, 2008, s. 4).

Det er mange aspekter ved et slikt økologisk perspektiv i skolen. Et viktig spørsmål i denne sammenheng er hvordan resultater i skolen gjentatte ganger synes å gjenspeile sosioøkonomiske forhold, til tross for norsk skoles sterke utjevningsmandat. Elever med middels til høy sosioøkonomisk bakgrunn har vedvarende sterkere skoleresultater enn elever fra hjem med lavere sosioøkonomisk status (Barne-, ungdoms- og familiedirektoratet, 2018). ${ }^{9}$ Her er det ikke enkle årsakssammenhenger, men det kan foreligge noen dypere samfunnsstrukturer som ser ut til å bidra 
slik at noen elever stadig sitter med trumfkort. I følge en slik økologisk tilnærming, vil det være viktig å gå slike strukturer i sømmene.

Et annet eksempel på en slik økologisk tilnærming til menneskeverd kan være å se nærmere på fysisk organisering av klasserom. Ulike måter å organisere skolen på er ikke bare praktiske innretninger, men bidrar til elevers læringsmuligheter og opplevelse av trygghet (Ahmad, Shaharim, \& Abdullah, 2017, s. 66). Materielle omgivelser blir dermed en drivkraft for læring, men også menneskeverd og etiske verdier. Et tredje aspekt handler om dannelsen av «hybrider» mellom menneske/ting (Haraway, 2008, s. 10). I skolen er digitale medier stadig mer viktig. Digitale medier brukes som verktøy i undervisningen, og de representerer mål i skolen ved digital kompetanse. Ikke bare det; digitale medier spiller en rolle også overfor overordnede mål med skolen og hvilke borgere skolen skal bidra til. Skolen har også å gjøre med elever, som nå er «digital natives» (Kivunja, 2014) - en annen type elever enn tidligere. Relasjoner og kontekster er ikke bare omgivelser for et statisk menneske, men mennesket endres - og med det også menneskeverdet.

Med «svake» tilnærminger til verdighet utmeisler vi på den ene siden en forståelse av menneskeverd som foranderlig, og på den annen side som relasjonell. Når mennesker handler, handler de alltid avhengig av kontekst, av andre mennesker og i en materiell kontekst. De kan ikke ses som løsrevet. En «svak» tilnærming til menneskeverd gir en mer sårbar forståelse for verdighet, der mennesket ses som art og vesen i en større økologisk og relasjonell kontekst.

\section{Drøfting: Mangfoldige forståelser for et mangfoldig menneskeverd}

I dette kapittelet har vi spurt hva som kjennetegner ulike tilnærminger til menneskeverd som begrep, og hvilke konsekvenser ulike tilnærminger kan ha for en skole som skal ivareta en mangfoldig elevgruppe. Utgangspunktet for dette kapittelet er at menneskeverd anses som «tatt for gitt» i skolens verdigrunnlag. Det viser seg at det er et begrep som i liten grad debatteres eller anvendes i skolesammenheng. Menneskeverd synes som et uanvendelig begrep, og når ikke helt fram til verken 
lærere, lærerutdannere eller elever. Utfordringen er at debattene om selve menneskeverdsbegrepet har en tendens til å befinne seg utenfor skole og utdanning.

Gjennom dette kapittelet har vi derfor presentert ulike tilnærminger til menneskeverdsbegrepet. De ulike tilnærmingene skal vise spennvidden og mulighetene i forståelsen av begrepet menneskeverd. I lys av de ulike tilnærmingene har vi gitt korte eksempler på eksisterende debatter i skolen. Disse er ikke bare eksempler på områder hvor praksis kan være problematisk, men illustrerer også ulike tilnærminger til menneskeverd. Spørsmål om hodeplagg for lærere eller tilpasset opplæring til elever er opphetede, men leder sjelden hen til en grundigere diskusjon eller kritisk refleksjon om hva begrepet menneskeverd kan bidra med. I skolen gjøres det likevel daglige valg som berører spørsmål om menneskeverd; elever oppmuntres eller blir oversett, velges og bortvelges, de respekteres eller krenkes. Dette har stor betydning for hva slags mangfoldig eller likeverdig samfunn skolen bidrar til. Dette har med verdighet å gjøre.

Man kan innvende at mangel på debatt om menneskeverd kan skyldes læreres mangel på kunnskap om hvordan man skal forstå begrepet. Imidlertid har vi en annen antakelse - nemlig at den rådende tilnærmingen til menneskeverdsbegrepet er for snever, og det medfører at begrepet ikke trekkes inn diskusjonene. Prosjektet har derfor vært å vise at det er et mangfold av ulike tilnærminger til begrepet menneskeverd. Gjennom disse ulike og mangefasetterte fortolkningene av menneskeverdsbegrepet ser vi også noen av spenningene og utfordringene knyttet til skolehverdagen.

Vårt argument i kapittelet er at menneskeverd kan ha «sterke» eller «svake» forståelser. Denne inndelingen viser noen grunnleggende motsetninger og spenninger på en annen måte enn for eksempel mer tradisjonelle og kronologisk historisk oversikt (som f.eks. Rosen, 2012), og representerer derfor et teoretisk bidrag til forståelsene av menneskeverdsbegrepet. I tillegg kan det å vise et mangfold av tilnærminger til verdighet også oppfylle en annen hensikt; å innlede en kritisk debatt om hva menneskeverdet kan bety for skolen.

En «sterk» tilnærming representerer forståelser som har vært etablert over lang tid, og som representerer en slags gjengs forståelse av menneskeverd. I henhold til en sterk tilnærming bygger man for det første på 
en slags «essens» ved mennesket. Mennesker har noen universelle trekk som gjør dem til mennesker, på tvers av sted eller tid. For det andre vil de «sterke» tilnærmingene beskrive mennesket som opphøyd fordi det er noe iboende, en form for metafysisk dimensjon i mennesket. For det tredje har mange tenkere med slike tilnærminger til menneskeverd i særlig grad framhevet mennesket som rasjonelt eller med særlige kapasiteter. Disse kvalitetene gir mennesker verdighet. For det fjerde kan menneskeverdet i den sterke tolkningen forstås som standarder og dyder som bekrefter menneskets verdighet når de blir utført. Mennesket blir verdig gjennom forhåndsdefinerte handlinger.

De «sterke» tilnærmingene til menneskeverd har vært gjenstand for omfattende kritikk. Spørsmålet er om det faktisk finnes en fellesmenneskelig essens, og det er sterk kritikk av en metafysisk essens. Alternativet kan være noe mindre bastant, det vi kaller en «svakere» tilnærming, der oppmerksomheten rettes mot livet nedenfra, fra faktiske handlinger og relasjoner. Menneskeverd er noe man tilskriver hverandre, og noe som utvikles i relasjoner med andre. Det at innholdet i menneskeverd ikke er bestemt, gjør at menneskeverd må defineres til stadighet. «Svake» tilnærminger ansvarliggjør ved at menneskeverd er noe som må gis.

Selv om vi i dette kapittelet har hentet ressurser fra menneskeverd hos juss, filosofi eller religion, vil ikke disse arenaene nødvendigvis kunne bidra med gode nok beskrivelser for hvordan man skal tolke og anvende menneskeverdet i skolen. Å se «sterke» og «svake» tilnærminger til menneskeverd kan være et viktig verktøy for skolen på ulike måter. Aller først: Skolens læreplan og lovverk synes å underbygges av en «sterk» tilnærming til menneskeverd. Disse grunnlagsdokumentene bygger på Menneskerettighetserklæringen fra 1948, som beskriver mennesket som unikt og likeverdig og med like rettigheter, og framheves som helt sentralt også i læreplanene fra 2020 (Utdanningsdirektoratet, 2018). ${ }^{10}$ Når det står i læreplanens overordnede del om «menneskeverdets ukrenkelighet og at alle mennesker er like mye verdt, uavhengig av hva som ellers

10 Læreplanene trer i kraft fra 2020. https://www.udir.no/laring-og-trivsel/lareplanverket/fagfornyelsen/ Hentet: 19.09.19. 
skiller oss»" ${ }^{11}$, settes det store krav til menneskeverd i skolen. Man kan si at en «sterk» forståelse signaliserer at menneskeverd har en helt sentral plass i skolen. Jo tydeligere parole, jo mer klarhet om begrepet. Imidlertid vil vi hevde at «sterke» tilnærminger til menneskeverd slett ikke styrker, men vil representere utfordringer som kan svekke anvendelsen av menneskeverd i skolen.

En grunnleggende utfordring med «sterke» tilnærminger til menneskeverd handler om dets basis som et abstrakt ideal - noe som alle mennesker har, og som ingen ønsker å stille spørsmål ved. Det er grunnpilaren som angår spørsmål om liv og død, komplekse medisinske, biologiske og genetiske grensedragninger. Samtidig foregår det en rekke hendelser i klasserommet som berører menneskeverd, men som man ikke helt klart kan definere. I løpet av en skoledag foregår det mange viktige ting - som at elevene opplever at de er verdsatt, at de lærer og trives. Samtidig kan det likevel være få kriterier for hva som egentlig kvalifiserer for å oppfylle idealene om unike eller likeverdige elever. En del elever kan oppleve å bli oversett eller utestengt. Noen elever opplever å bli mobbet. Man kan stille seg spørsmålet: Hvis det er riktig at menneskeverdet representerer en urokkelig standard for det gode, hvorfor er det så vanlig å krenke det? Og hva kvalifiserer for en krenkelse? Elever og lærere gjør en rekke ting som strider med «det menneskelige», slik det er forstått som en sterk, moralsk standard. Man kan si at utfordringen med abstrakte, metafysiske idealer i skolen er at mangfoldet av dagligdagse hendelser rett og slett er for ordinære. Menneskeverdet handler om store spørsmål, og begrepet blir kanskje for stort for hverdagen. Det oppstår et problem med korrespondansen mellom ideal og virkelighet i skolen, der man mangler språk for mangfoldet av menneskeverd som kan utspille seg i praksis og i handling.

En konsekvens av «sterke» tilnærminger kan være at menneskeverd blir stående som et litt utdatert og uanvendelig begrep for lærerne. Dette kan være en mulig årsak til at menneskeverd heller ikke når helt fram til lærerværelser og klasserom, og at begrepet er vanskelig å bruke i spørsmål om læringsmiljø. Dette er ikke nødvendigvis «lærernes feil». I stedet for å kritisere kunnskapen om menneskeverd i skolen, vil vi hevde at den

11 https://www.udir.no/lk2o/overordnet-del/opplaringens-verdigrunnlag/1.1-menneskeverdet/ 
rådende og «sterke» forståelsen av menneskeverd i seg selv kan hindre at begrepet oppfattes som relevant for reelle problemstillinger som lærere kan erfare i hverdagen.

En annen kritikk til «sterke» tilnærminger handler om hvilken vekt skolen skal legge på det rasjonelle som standard for menneskeverd. Utvikling av elevenes rasjonelle evner er helt klart viktig i skolen. Spørsmålet kan være hvordan man vil forholde seg til elevmangfoldet. Menneskeverd som rasjonelle evner er avgjørende i debatter om inkludering av elever med særskilte behov i skolen. Hvordan skal man for eksempel beskrive menneskeverd hos elever med svakere mentale evner? Hvis det skal beskrives med allmenn-menneskelige behov og kapasiteter - hvilke av disse er det viktigst å oppfylle i skolen?

Menneskeverd kan også problematiseres for den «jevne elev». Elevundersøkelsen fra 2018 viser at motivasjon og trivsel i skolen jevnt over er på sitt laveste for 10. trinn - det vil si når elevene aller helst både skulle ha lært mye, og lagt planer for framtid og videre utvikling (Utdanningsdirektoratet, 2019). ${ }^{12}$ Mange vil forklare denne lave motivasjonen med manglende mening og helhetlige tilnærminger til læring i skolen. Det kan derfor være behov for å se mer sammenheng. Slike sammenhenger kan handle om at skolen i større grad bør se sosiale og materielle behov i lokalsamfunnet opp mot skolens virksomhet, og å se eleven som en helhet av sosiale og biologiske behov og ressurser. Dette kan skolen blant annet imøtekomme med mer dybdelæring (Gilje, Landfall \& Ludvigsen, 2018). ${ }^{13}$ Dersom dybdelæring er responsen på noe mer enn rasjonalitet som merkestein for skolen, vil det da være viktig å vende fokus mot innholdet i menneskeverdsbegrepet. Her savner vi en grunnleggende diskusjon i skolen, ikke bare om hva som gir mest effektiv og helhetlig læring som et instrumentelt behov hos skolen. Vi mener også at det kan representere en mulighet for skolen til å drøfte menneskeverdsbegrepet, og hvilke aspekter ved menneskeverd som aktivt velges, og hva som velges bort. Dybdelæring om menneskeverdet krever etter vår mening at

12 https:/www.udir.no/tall-og-forskning/finn-forskning/rapporter/analyse-av-laringsmiljoindeksene-fra-elevundersokelsen-2018. Hentet: 08.10.19.

13 https://www.utdanningsnytt.no/fagartikkel-forskning-pedagogikk/dybdelaering--historisk-bakgrunn-og-teoretiske-tilnaerminger/171562. Hentet 21.10.19. 
man i undervisningen og i skolens interne fora arbeider med både sterke og svake tolkninger av menneskeverdet. Man kan ikke ta for gitt at de «sterke» tolkningene av menneskeverdbegrepet vinner gehør og tilslutning blant den sammensatte elevgruppen som finnes i norsk skole i dag. Det er derfor viktig å åpne begrepet på flere måter for at det kan kommunisere med elever med forankring i et mangfold av normative tradisjoner.

Vi ser altså noen helt grunnleggende utfordringer med «sterke» tilnærminger til menneskeverd i skolen. Disse kan bidra til mangel på begreper for menneskeverd, mangel på hjelp til å se et tilstrekkelig mangfold i selve menneskeverdsbegrepet. Vi etterlyser debatt og et kritisk blikk på hvordan menneskeverd praktiseres og forstås i skolen i dag. Tilnærminger som vi betegner som «svake» kan derfor være avgjørende, og åpne for nye perspektiver og muligheter. Svake tilnærminger har til felles det konkrete, og ser på samhandlingene i relasjoner som den viktigste dimensjonen for menneskeverd. Den krevende utfordringen med de «svake» tilnærmingene er imidlertid at de ikke er gitt. Hva man forstår med respekt for menneskeverdet utvikles og får nytt innhold gjennom nye situasjoner og behov.

De «svake» tolkningene kan være viktige bidrag for å grunnfeste menneskeverd i handling, og for å gi rikere og dypere forståelser av hva menneskeverd innebærer. Et av de aller viktigste bidragene her er tolkningen av at menneskeverd er ikke noe som bare «er», men noe som kaller på vår evne til å ta ansvar, og til å stadig tilskrive elever, lærere og ledelse verdighet. Det er et daglig arbeid. Begreper, valg og bortvalg må stadig debatteres. Det må mangfoldige forståelser til for å kunne utvikle et mangfoldig menneskeverd i skolen.

\section{Forfatteromtale}

Ådne Valen-Sendstad er førsteamanuensis ved Universitet i Sørøst-Norge ved Fakultet for humaniora, idrett og utdanningsvitenskap. Han har en PhD fra University of Birmingham. Han arbeider med etikk, filosofiske forståelser av menneskerettigheter og menneskerettighetsundervisning. Han har publisert om menneskerettigheter i skolen, barnets beste, demokrati og normativ pluralisme. 
Ingrid Reite Christensen er førsteamanuensis i pedagogikk og spesialpedagogikk ved Universitetet i Sørøst-Norge. Hun forsker på mangfold, demokrati og medborgerskap, livsmestring og psykososial helse i skolen og profesjonslæring. Hun leder for tiden også internasjonale prosjekter om demokrati og medborgerskap og elevsentrert undervisning. Feltet hennes er tverrfaglig der fellesnevneren er profesjon, medvirkning og mangfold i skolen.

\section{Referanser}

Ahmad, C. N. C., Shaharim, S. A., \& Abdullah, M. F. N. L. (2017). TeacherStudent Interactions, Learning Commitment, Learning Environment and Their Relationship with Student Learning Comfort Journal of Turkish Science Education, 14(1), 57-72. doi: 10.12973/tused.10190a

Dupré, C. (2015). The Age of Dignity. Oxford and Portland, Oregon: Hart Publishing. Forskningsdepartemetet. (1996). Loreplanverket for den 10-årige grunnskolen. Oslo: Kirke- og undervisningsdepartementet.

Gewirth, A. (1996). The Community of Rights. Chicago, London: The University of Chicago Press.

Habermas, J. (2010). The Concept of Human Dignity and the Realistic Utopia of Human Rights. Metaphilosophy, 41(4), 464-480.

Harari, Y. N. (2018). 21 tanker for det 21. århundret. Oslo: Cappelen Damm.

Haraway, D. (2008). When Species Meet. Minneapolis: University of Minnesota Press.

Hollenbach, D. (2014). Human dignity in Catholic thought. I M. Düwell, J. Braarvig, R. Brownsword, \& D. Mieth (Red.), The Cambridge Handbook of Human Dignity; Interdisciplinary Perspectives. Cambridge: Cambridge University Press.

Ignatieff, M. (2001). Human Rights as Politics and Idolatry. Princeton and Oxford: Princeton University Press.

Kant, I. (1785/2012). Groundwork of the Metaphysics of Morals (Revised Edition ed.). Cambridge: Cambridge University Press.

Kant, I. (1797/2017). The Metaphysics of Morals. Cambridge: Cambridge University Press.

Kateb, G. (2011). Human Dignity. Cambridge, Massachusetts and London, England: The Belknap Press of Harvard University Press.

Kivunja, C. (2014). Theoretical Perspectives of How Digital Natives Learn. International Journal of Higher Education, Volume 3, 94-109. doi:10.5430/ijhe.v3n1p94

Kolnai, A. (1995). Dignity. I R. S. Dillon (Red.), Dignity, Character and Self-Respect. New York, London: Routledge. 
Kunnskapsdepartementet. (2015). Fremtidens Skole. Fornyelse av fag og kompetanser. Oslo: Kunnskapsdepartementet.

Köhler-Olsen, J. (2010). Forbud mot niqab og burka i den offentlige skolen. Lov og Rett, 49(7), 407-422.

Levinas, E. (1969/2007). Totality and Infinity. Pittsburgh, Pennsylvania: Duquesne University Press.

Loughlin, J. (2016). Human Dignity: the Foundation of Human Rights and Religious Freedom/La dignidad humana: el fundamento de los derechos humanos y de la libertad religiosa. Memoria Y Civilización, 19, 313-343. doi: 10.15581/oo1.19.313-343

Løken, H. N., \& Stubø, I. (2018). Menneskeverd og solidaritet: om individbaserte og fellesskapsorienterte verdier i opplæringslovens formålsparagraf. I E. Schjetne \& T.-A. Skrefsrud (Red.), A vore loerer i en mangfoldig skole: kulturelt og religiøst mangfold, profesjonsverdier og verdigrunnlag. Oslo: Gyldendal.

Macklin, R. (2003). Dignity is a useless concept. British Medical Journal, 327, 1419.

Mantouvalou, V. (2011). In support of Legalisation. I C. Gearty \& V. Mantouvalou (Red.), Debating Social Rights. Oxford and Portland, Oregon: Hart Publishing.

Marcel, G. (1963). The Existential Background of Human Dignity. Cambridge, Massachusetts: Harvard University Press.

Margalit, A. (1998). The Decent Society (N. Goldblum, Trans.). Cambridge, Massachusetts and London: Harvard University Press.

Margalit, A. (2011). Human dignity between kitsch and deification I C. Cordner (Red.), Philosophy, Ethics and Common Humanity London and New York: Routledge.

Maritain, J. (1948). Introduction. In UNESCO (Red.), Human Rights: Comments and Interpretations: A Symposium edited by UNESCO. http://unesdoc.unesco.org/ images/o015/o01550/155042eb.pdf.

Maritain, J. (1952). Man and the State. New York: The University of Chicago Press.

McCrudden, C. (2008). Human Dignity and Judicial Interpretation of Human Rights. European Journal of International Law, 19(4), 655-724.

Mirandola, P. d. (1998, (1463-1494)). On the Dignity of man. Indianapolis, Cambridge: Hackett Publishing Company.

Morsink, J. (1999). The Universal Declaration of Human Rights, Origins, Drafting and Intent. Philadelphia: PENN, University of Pennsylvania Press.

Morsink, J. (2009). Inherent Human Rights: Philosophical Roots of the Universal Declaration. Philadelphia: University of Pennsylvania Press.

Moyn, S. (2015). Christian Human Rights. Philadelphia, Pennsylvania: University of Pennsylvania Press.

Nussbaum, M. (2000). Woman and Human Development: The Capabilities Approach. Cambridge, MA: Cambridge University Press.

Nussbaum, M. (2008a). Duties of Justice, Duties of Material Aid. Cicero's Problematic Legacy The Journal of Political Philosophy, 8(2), 106-206. 
Nussbaum, M. (2008b). Human Dignity and Political Entitlements. I A. Schulman (Red.), Human Dignity and Bioethics: Essays Commissioned by the President's Council on Bioethics https://bioethicsarchive.georgetown.edu/pcbe/reports/human dignity/chapter14.html.

Nussbaum, M. (2011). Creating Capabilities; The Human Development Approach. Cambridge, Massachusetts \& London, England: The Belknap Press of Harvard University Press.

Opplæringslova. (1998). Lov om grunnskolen og den vidaregåande opplæringa. Patel, D. (2005). The Religious Foundations of Human Rights: A perspective from the Judeo-Christian Tradition and Hinduism. Human Rights Law Commentary, 1.

Perry, M. J. (2007). Toward a Theory of Human Rights. Cambridge, New York: Cambridge University Press.

Pinker, S. (2001). The Stupidity of Dignity. Hentet fra: https://richarddawkins. net/2012/10/the-stupidity-of-dignity/.

Robcis, C. (2016). The Biopolitics of dignity. South Atlantic Quarterly, 115(2), 314-320.

Rosen, M. (2012). Dignity Past and Present. I M. Dan-Cohen (Red.), Dignity, Rank, \& Rights. Oxford, New York: Oxford University Press.

Rosen, M. (2012). Dignity; Its History and Meaning. Cambridge, Massachusetts and London; England: Harvard University Press.

Sensen, O. (2011a). Human dignity in historical perspectives: The historical and contemporary paradigms European Journal of Political Theory, 10(1), 71-91.

Sensen, O. (2011b). Kant on Human Dignity. Berlin and Boston: De Gruyter.

Slagstad, R. (1998). De nasjonale strateger. Oslo: Pax Forlag AS.

Tapola, A. M. (2011). Human dignity within teacher education: A matter of individualism, competitiveness, and strategic rationality. Teaching \& Teacher Education, 27(8), 1245-1254. doi:10.1016/j.tate.2011.07.004

Vesterdal, K. (2016). The roles of Human Rights Education in Norway: A Qualitative Study of Purposes and Approaches in Policy and in Upper Secondary Schools. (Doktorgradsavhandling), NTNU Trondheim, Tronheim. Hentet fra: http://hdl. handle.net/11250/2390573

Waldron, J. (2012). Dignity, Rank, \& Rights. Oxford, New York: Oxford University Press.

Waldron, J. (2017). One Anothers's Equals. Cambridge, Massachusetts and London: The Belknap Press of Harvard University Press. 


\title{
Verdig = vanlig og norsk: Nyankomne ungdommers verdighet i introduksjonsklasser
}

\author{
Ingrid Reite Christensen \\ Universitetet i Sørøst-Norge
}

Yes, ass

I Norge, ass.

Jeg er klar, ass

Jeg skal gå, ass

Ja. Æss

(Alan, afghansk gutt, 14 år, kommentar i friminutt)

\begin{abstract}
In a society of global mobility and flows of refugees and internally displaced people, the question of dignity is critical. This In this chapter I ask what characterises dignity among newly arrived youth in their everyday lives at school in Norway. Newly arrived youth are in a fragile state in becoming well-integrated citizens and a productive part of society. These young people have a past to cope with, a present to orient themselves in, and they are also are obliged to succeed in the future. Their dignity is due to their possibilities to act in a complex world. This chapter takes a starting point in the data material from participant observation in a so-called "introduction class" in Norway for newly arrived youth. An introduction class is a first phase of schooling offered prior to a transferal to local, public schools. I present an everyday situation as this transfer takes place, and read it through the lens of Deleuze and Guattaris posthuman ethics. More than predefined given rights, dignity is explored as experiences of equality and as possibilities to act in everyday lives. The material shows high motivation and anxieties of pupils and teachers in the transfer process to local schools. The prerequisites for joining their local school classes, however, is not clear for the pupils. The teachers encourage the pupils to work hard and suggest a number of actions in order to join regular schools and becoming so-called "ordinary". The analyses conclude that equality seems a high, but hidden standard. The results may be that in practice, pupils are not treated as equals, and that the ideals of dignity do not seem relevant. These findings point out a lack of relevant concepts of dignity in school. In spite of high standards of dignity in the curriculum, the newly arrived youth may
\end{abstract}

Sitering av denne artikkelen: Christensen, I. R. (2019). Verdig = vanlig og norsk: Nyankomne ungdommers verdighet i introduksjonsklasser. I Å. Valen-Sendstad \& I. R. Christensen (Red.), Menneskeverd en utfordring for skole og samfunn (Kap. 2, s. 39-61). Oslo: Cappelen Damm Akademisk. https://doi. org/10.23865/noasp.9o.ch2.

Lisens: CC BY-NC 4.o. 
suffer from inequalities. I argue that there is a need for a debate on the concepts of dignity in school. I promote a dynamic understanding of dignity, embracing diversity and the specific needs of the pupils, as well as strengthening the teacher's agency.

Keywords: Dignity, refugee education, posthuman ethics, citizenship, inclusion

\section{Introduksjon: Spørsmålet om verdighet for nyankomne ungdommer}

I et samfunn med økt mobilitet og en pågående global flyktningstrøm er menneskeverd og verdighet et hett spørsmål. I dette kapittelet vil jeg utforske hva som kjennetegner nyankomne elevers verdighet i skolens introduksjonstilbud. For nyankomne elever er det svært mye av livet som er i støpeskjeen. De lever i et nytt land, bor i en ny bolig, lærer seg et nytt språk og får nye venner på en ny skole. Samtidig står de i et sterkt krysspress og skal også håndtere utfordringer som tap av hjemland, kultur, venner og familie. Dette kan i høyeste grad kalles en eksistensiell korsvei. Hva som skaper det gode og verdige liv, er alt annet enn gitt. Midt i dette scenarioet skal de nyankomne elevene likevel skape seg et handlingsrom og en framtid, hvor de kan delta og være bidragsytere i samfunnet.

Skolen ser menneskeverd og verdighet som grunnleggende verdier (Opplæringslova, 1998, \$1-1). Imidlertid er også verdighet noe skolen skal bidra til gjennom inkludering og likeverd, der likeverd er verdier som må ivaretas og forsterkes. Elevene skal også «gis likeverdige muligheter slik at de kan ta selvstendige valg». (Kunnskapsdepartementet, 2017). Menneskeverdet innebærer derfor både et grunnleggende verdisett, noe som skal utvikles - og noe som gir muligheter for deltakelse. Menneskeverd og verdighet beskrives ofte som det å gi likeverdig opplæring, som er en særlig utfordring overfor mangfoldet som nyankomne elever representerer. ${ }^{1}$ Man kan si at begrepene menneskeverd og verdighet fungerer som skolens prøvesteiner for inkludering av nyankomne.

Imidlertid er menneskeverd et lite konkretisert begrep i skolen, både i etiske drøftinger og i undervisning (Vesterdal, 2016). Menneskeverd og likeverd har også endret seg markant de siste 20 årene, og innholdet i 
disse begrepene er et samspill mellom en rekke faktorer (Nilsen, Bjørnsson et al., 2018). Det kan derfor være behov for å undersøke faktorene som påvirker forståelsen av menneskeverd overfor nyankomne elever. I denne sammenheng vil det være interessant å se hvordan menneskeverd som samhandlinger i klasserommet. Jeg spør: Hva kjennetegner nyankomne elevers verdighet i skolen?

I dette kapittelet behandles menneskeverd og verdighet om hverandre. På engelsk har «human dignity» og «dignity» overlappende betydning, mens det i europeisk sammenheng kan ha noe ulike valører i henhold til hvorvidt de betegner en grunnleggende menneskelige trekk eller status i samfunnet. ${ }^{2}$ Skolen synes å operere med ulike begreper, som ofte konkretiseres til «likeverd». I dette kapittelet problematiserer jeg derfor samhandling i klasserommet for nyankomne elever. Denne samhandlingen skaper forståelser av verdighet. Hensikten med kapittelet er å vise at menneskeverd og verdighet er begreper som er i bevegelse, og at det får konsekvenser for likeverdig behandling av elever.

Kapittelet begynner med en introduksjon om nyankomne ungdommer i Norge og deres utfordringer i skolen. Gjennom Deleuze og Guattaris posthuman etikk settes søkelyset på hvordan verdighet kan sees som et samspill mellom ulike faktorer.

Etter en beskrivelse av metodiske valg tar jeg for meg to utdrag fra datamaterialet jeg har etter deltakende observasjon i en introduksjonsklasse. Jeg tar utgangspunkt i to hverdagssituasjoner i introduksjonsklassen og beskriver dem med noen begreper fra Deleuze og Guattaris posthumane etikk. Samspillet mellom elever, lærere og klasserom er i fokus. Jeg ser på hvordan både sosiale og praktiske faktorer i hverdagen støtter opp om ulike former om verdighet. Fysiske omgivelser, hjem og foresatte, skolemiljø og skoleledelse kan påvirke hvordan likeverd og verdighet forståes og praktiseres i skolen (Sørensen, 2009). I dette samspillet skapes muligheter og begrensninger for nyankomne elever. Spørsmålet er om elevene ikke bare blir betegnet som verdige og likeverdige, men om de i praksis blir behandlet som dette. Jeg argumenterer for at menneskeverd er et begrep i støpeskjeen, og at det er sårbart for hva som foregår hver dag i klasserommet.

2 Se introduksjonskapittelet for ytterligere beskrivelser av forholdet mellom menneskeverd og verdighet. 


\section{Nyankomne ungdommers skolesituasjon i Norge}

Nyankomne ungdommer får i Norge tilbud om utdanning. Norsk lovverk gir alle barn og unge under 18 år som skal oppholde seg 3 måneder eller mer i Norge, rett til opplæring, og også særskilt språkopplæring (Opplæringslova, $\S_{2-1} \$ \$_{2-8}$ ). Denne opplæringen organiseres mange steder sentralisert i kommunene, som vil si at kommunen etablerer introduksjonstilbud på én lokasjon og ikke på hver enkelt skole (Opplæringslova, $\$ 3-12$ ). Introduksjonstilbudet går under flere navn: mottaksklasser, introduksjonsklasser eller velkomstklasser. Slike introduksjonsklasser representerer ofte et første møte med Norge, samtidig som man møter en rekke elever i liknende livssituasjon. Nyankomne ungdommer har felles at de har få eller ingen forkunnskaper i norsk. Imidlertid har elevene har svært forskjellig bakgrunn. Noen har måneder og år bak seg som flyktninger. Flere har foretatt denne reisen alene og bor med verger i egne boliger. Andre kommer hit fordi foreldre har fått jobb i Norge. Noen har mer eller mindre avbrutt skolegang, mens andre ligger foran norske elever faglig.

Det er behov for kunnskap om de ulike utfordringene elever i introduksjonsklasser har som nyankomne. Det er særlig to felt forskning på nyankomne ungdommer konsentrerer seg om, både i Norge og internasjonalt (Bansak, Hainmueller et al., 2016; Eide \& Broch, 2010; Matthews, 2008; Rutter, 2006). På den ene siden etableres tiltak for introduksjonsklasser med vekt på effektiv språkinnlæring. Grundig kunnskap om språkutvikling og -didaktikk er helt avgjørende redskaper for deltakelse i samfunnet og ligger til grunn for mandatet for introduksjonsklassene. På den andre siden ivaretas nyankomne ut fra en psykologisk tilnærming med fokus på traumer og eventuell traumekompetanse hos lærere (Pastoor, 2016; Schultz, Marshall et al. 2016). Hvorvidt ungdommene utvikler omfattende psykiske vansker, er avhengig av omfang av traumer, individuelle mestringsressurser, men også av omgivelsenes kunnskaper og holdninger (Neumayer, Skreslett et al. 2006, s. 17). Å utruste skolen med kunnskap om traumer og verktøy for bedre psykososial helse er nødvendig for de ungdommene dette gjelder. Det å håndtere hverdagen på en konstruktiv måte kan kreve store ressurser fra den enkelte (Pastoor, 2013). Flere nyankomne ungdommer har svært ulike erfaringer fra oppbrudd og reise til 
Norge. Noen kommer som barn av arbeidsinnvandrere. Imidlertid har mange ungdommer med kort botid opplevd traumatiske hendelser, flukt, spenninger og frykt over lang tid. De må håndtere en vanskelig fortid, og mange sliter med psykiske vansker (Mollica, Lopes Cardozo et al. 2004; Perumal, 2015). Å komme til Norge er derfor en sammensatt prosess, der nyankomne ungdommer må håndtere rekke praktiske, psykiske og sosiale utfordringer.

Grundig kunnskap om både språk, flerspråklighet og psykososial helse er avgjørende for å gi god opplæring til nyankomne i skolen. Rutter (2006) og Matthews (2008) peker også på behovet for å utvikle etiske drøftinger rundt nyankomnes etablering, sosiale status og handlingsrom for et godt og verdig liv i samfunnet. Dette kapittelet utforsker noe av kompleksiteten når nyankomne elever skal etablere verdighet i skolehverdagen. Beskrivelser av skolehverdagen er ikke bare praksisfortellinger; de kan utgjøre dilemmaer som også kan løfte fram etiske spørsmål om hva som definerer menneskeverd og verdighet for nyankomne.

\section{Ulike tilnærminger til verdighet - og «posthuman etikk»}

I dette kapittelet vil jeg utforske hva som kjennetegner nyankomne elevers verdighet i introduksjonsklasser. Hva mener jeg så med begrepet verdighet? ${ }^{2}$ Én vanlig forståelse er at mennesket har visse felles iboende kvaliteter, en menneskelig essens. Disse kvalitetene utgjør en felles verdi for mennesket, en slags «fastpris» som ikke skal fravikes (Kant, 1785/1998, s. 42). ${ }^{4}$ Denne forståelsen av verdighet bygger blant annet på at mennesket innehar en rekke iboende og felles kvaliteter, som autonomi

3 Se introduksjonskapittelet til Valen-Sendstad og Christensen for nærmere oversikt over ulike forståelser verdighet og Arntzens kapittel for nærmere beskrivelser av et kantiansk utgangspunkt for etikk.

4 Etiske tilnærminger som søker samsvar mellom forhåndsgitte standarder og praksiser, blir av Barad (2003) kalt en «representativ etikk». En representativ etikk vil for eksempel etter en kantiansk etikk søke verdighet som iboende abstrakte kvaliteter ved nyankomne elever, som er transcendentale gjennom historie og gjeldende for alle kulturer. Det kan også innebære en empirisk kartlegging av ulike fysiske og psykiske behov hos nyankommen ungdom, og dermed et utgangspunkt for et universelt behov for verdighet, som blant annet Nussbaum argumenterer fram (Lysaker, 2015). 
og fornuft. Disse kvalitetene setter standarden for menneskeverd (Kant, 1785/2002, s. 54).

$\AA ̊$ være gitt retten til utdanning betyr ikke nødvendigvis at ungdommer får god opplæring. Objektive, universelle standarder for verdighet kan komme til å vise seg for «fattige» (Barad, 2003, s. 801; Tamsin 2011). Generelle standarder for verdighet favner ikke nødvendigvis opplæringen til nyankomne i all sin kompleksitet. En annen tilnærming ser derfor verdighet som uløselig knyttet til historisk sammenheng og kultur og beskriver en form for deltakelse. Denne tilnærmingen favner såkalte empiriske og konstruktivistiske tilnærminger til etikk. Empiriske tilnærminger til verdighet funderes i menneskets egne erfaringer. Erfaringene er hva som gjør mennesket til et menneske (Winter, 1994, s. 239) Ut fra erfaringen skapes sosiale normer og moralske regler som påvirker forståelsen av å være verdig (Taylor, 1989, s. 92-93). Det er derfor de nyankomnes faktiske utfordringer i hverdagen som bør danne utgangspunkt for hva verdighet er.

I introduksjonsklassen er det mange slags faktorer som bidrar til nyankomnes verdighet. Verdighet kan være avhengig av elevenes ulike kulturelle bakgrunn og personlige historier, av lærernes profesjonsetos og engasjement, eller skoleverkets mandat for introduksjonsklasser. En rekke virkeligheter og erfaringer, både sosiale og materielle, skaper avgjørende øyeblikk for hva som er det ideelle og det gode liv for nyankomne. Det er erfaringer som er utgangspunktet for å dra veksel på Deleuze (1990, 2009) og Deleuze og Guattari (1987), og det de kaller en situasjonsbestemt og "posthuman» etikk. Selv om Deleuze og Guattari verken beskriver verdighet, skole eller nyankomne som sådan, kan en lesning av dem gi noen viktige stikkord for å forstå verdighet på nye måter

Et første overordnet aspekt hos Deleuze og Guattari er at etikk er situasjonsbestemt. I stedet for at standardprinsipper for rett og galt skal styre handling, forsøker Deleuze og Guattari i stedet å beskrive konkrete handlinger. Etikk finnes i handlingen, som Deleuze og Guattari kaller en «event», en hendelse. Hendelsen er sentral. Hendelser kan beskrives som bestemte, innholdsfylte møter. Forhåndsbestemte idealer, som for eksempel «likeverd», er kanskje ikke tilstrekkelig for å skape gode nok beskrivelser av hva som er problematisk i handlingen. I stedet er det nødvendig å se på hvem og hva som bidrar til handlingen (Deleuze, 2009). 
Deleuze ser etikk i kontrast til «moral». Moral representerer bedømmelser av om handlinger er gode eller onde, hevder Deleuze (Deleuze, 1980). I moralen handler det om å være lydig mot fastsatte verdier. Dersom man følger moralens logikk, bedømmer man «godt» eller «ondt», «verdig» eller «uverdig», etter situasjoner som allerede har skjedd på et annet sted til en annen tid. Satt på spissen ser Deleuze moral som mer stivbeinte regler og dermed til mindre hjelp for det rette og gode i en situasjon. Etikk, derimot, er et slags motstykke til moral. Etikk utvikles i nåtid, den er immanent. Etikk oppstår $i$ handlingen, ikke utenfor. Dermed kan f.eks. verdighet beskrives som en prosess og en form for eksistens, der individet blir til (Deleuze, 2009, s. 8).5

For det andre kan Deleuze og Guattaris etikk kalles «posthuman». «Posthuman» kan oppfattes som et uforståelig begrep for mange når man snakker om menneskeverd. Imidlertid betyr ikke «posthuman» at mennesker settes på sidelinjen (Tamsin, 2011, s. 75). ${ }^{6}$ I stedet er Deleuze og Guattari på jakt etter hva som setter betingelsene for menneskeverd i en situasjon. Dermed må man analysere hvilke faktorer som kan være med å definere menneskeverd. Faktorene må «vikles» fra hverandre. Dersom man forstår hvem og hva som virker inn på samhandling, kan man også forstå mer om etikk og menneskeverd. Faktorene for menneskeverd kan ikke bare være noe «innenfra» i mennesket, som rasjonalitet eller en abstrakt iboende verdi. Det er heller ikke bare snakk om verdighet som en fast sosial status.? I stedet kan menneskeverd være noe som «gjøres». I introduksjonsklassene kan derfor verdighet være et resultat av samhandlingen mellom f.eks. lærere, elever språk og begrepsbruk, fysiske omgivelser, bestemmelser i skolen, rutiner osv. Alle disse faktorene er både menneskelige og «mer enn det menneskelige», og sammensetningen («assemblage») bidrar til å skape identitet. (Deleuze \& Guattari, 1994, s. 146).

5 Identitet og menneskeverd etableres i samhandling og som en gjensidig og kontinuerlig skapelsesprosess. Å gjennomgå slike forandringer gjør identitet til «nomadisk» og underveis (Deleuze \& Guattari, 1987, s. 380).

6 Deleuze og Guattari har ikke til hensikt å underminere menneskeverdet. Imidlertid etablerer Deleuze og Guattari en alternativ tilnærming til identitet og menneskeverd. På den ene siden ser de det som lite fruktbart å behandle én kjerneidentitet som er indre og stabil (Tamsin, 2011). Deleuze og Guattari (1994, s. 146) tar også et oppgjør med identitet som kun ytre bestemt av et sosialt miljø. De ser identitet som mer enn sosial fortolkning og etablert gruppetenkning. Se introduksjonskapittelet for ytterligere beskrivelse av slike forståelser av menneskeverd. 


\section{Hva er så resultatene av en handling? Sterke eller svake handlingsrom}

Deleuze (2009) understreker at handlinger i seg selv ikke kan beskrives som enten gode eller onde. Dette innebærer at det for eksempel ikke lærerens enkelthandlinger som skaper verdighet hos nyankomne. Det gode kan i stedet sees som summen av handlinger.8 (Deleuze \& Guattari, 1987)

Spørsmålet videre er om summen av handlinger representerer et positivt menneskeverd, og hva som i så fall er kriteriene for verdighet for nyankomne ungdommer. Afdal, Røthing og Schjetne (2014, s. 24) foreslår at verdighet er det som skaper muligheter og begrensninger for det gode liv (Afdal, Røthing \& Schjetne, 2014). For nyankomne ungdommer kan hendelser på skolen gi både muligheter og sette begrensninger for handling. En Deleuze-tilnærming vil derfor kunne i at verdighet handler om hvorvidt nyankomne ungdommer får handlingsrom og muligheter videre.

Dersom verdighet handler om nyankomnes mulighetsrom, vil det $\mathrm{i}$ følge Deleuze og Guattari kunne være snakk om begrensende handlingsrom og mer åpne handlingsrom. Å bli en del av et veletablert miljø kaller Deleuze og Guattari for «becoming majoritarian». Såkalte majoritære miljøer er en form for sosiale «territorier» hvor det er et etablert og dominerende sett av regler og normer. Poenget hos Deleuze og Guattari er at etablerte miljøer ikke bare «er der», men at de skapes (1987, s. 5).

På den annen side kan samhandling resultere i det motsatte. I noen sosiale miljøer kan sosiale mønstre være mindre etablerte. Dette beskriver Deleuze og Guattari (1987, s. 291) som «becoming minoritarian» (minoritær). Å være minoritær handler ikke om å være en kulturell minoritet, slik vi kjenner det. Minoritære fellesskap kjennetegnes av å være mer preget av forskjeller mellom medlemmene, der man som medlem ikke så lett lar seg definere (Deleuze \& Guattari, 1987, s. 470). Å være minoritær kan beskrives som en sårbar, men også åpen posisjon for identitet.

8 Deleuze og Guttaris etikk må ikke forveksles med ren nytteetikk, som fokuserer på hva som fører til lykke for flest mulig. Jf. Bentham eller Smith, er det gode en slags forhåndskalkulasjon av mest mulig nytte for flest mennesker (se Valen-Sendstads kapittel for nærmere beskrivelse). Deleuze representerer i stedet en kunnskapssosiologisk og poststrukturalistisk kritikk til moralog kunnskapspolitikk. Han oppfordre til å se på etikk som utvikles som en følge av hendelser og situasjoner, og som kan si noe om maktmønstre og samhandling i samfunnet. 
I et klasserom kan derfor elever følge mer eller mindre fastsatte sosiale mønstre. Sosial samhandling er med på å avgjøre identitet. I stedet for å fokusere på hva mennesket er «er», vil Deleuze beskrive hvem menesket «blir» i relasjoner med andre. Han kaller dette for «becoming-other». Mennesker er i en stadig danningsprosess i sine relasjoner til andre, og man kan anta ulike identiteter (Deleuze, 1995, s. 44; Deleuze \& Guattari, 1987, s. 462).

Det som er verdt å merke seg ved Deleuze og Guattari, er at identitet ikke bare er en slags gitt sosial status, men at den stadig kan formes og skapes. Overført til spørsmålet om nyankomne elever, blir klasserommet et skapende sted, og samhandlingen er avgjørende, ikke bare for kunnskap, men for verdighet. I stedet for å se på verdighet som en statisk størrelse noen har eller ikke har, fokuserer jeg på verdighet som situasjonsbetinget, en prosess der de selv er medskapere. I de kommende eksemplene fra klasserommet, vil det derfor på den ene siden være nyttig å se på faktorer og aktører som bidrar i dannelsesprosessene. På den annen side vil det være nyttig å analysere hvilke muligheter og begrensninger som gis til ulike identiteter. Imidlertid er det aller først duket for en kort oversikt over metodologiske valg og vurderinger ved utvalget av casen med ungdommene i introduksjonsklassen.

\section{Forskningsdesign og metode: En kvalitativ casestudie}

For å utforske hva som kjennetegner nyankomne elevers verdighet i introduksjonsklasser, har jeg utført en komparativ kvalitativ casestudie (Riege, 2003; Flyvbjerg, 2011). Utvalget for studien er i dette kapittelet introduksjonsklassen ved en ungdomsskole i en by på Østlandet i Norge. Introduksjonsklassen i denne casen har elever fra 8. til 10. trinn. Den er delt inn i to grupper hovedsakelig etter norskspråklige ferdigheter. Det å velge én case er en spennende og intensiv undersøkelsesform som kjennetegnes av at man får et fyldig og detaljert datamateriale fra avgrensede eksempler. Jeg ble godt kjent med skolen, med lærere og også noen elever. Et slikt lite utvalg gir ikke materiale som er statistisk generaliserbart for introduksjonsklasser. I stedet representerer ofte enkeltcaser en 
mulighet til å skape dybde i teoretiske begreper og er «analytisk generaliserbare». Analytisk generalisering kan beskrive hendelser som også er gjenkjennbare i liknende klasser, og som har til hensikt å utvide en teoretisk forståelse av et fenomen, slik som verdighet (Roald \& Køppe, 2009; Flyvbjerg, 2011).

Utdraget i dette kapittelet er materiale fra en større studie i introduksjonsklasser i Norge. Studien har et kvalitativt forskningsdesign med deltakende observasjon, såkalt etnografisk skygging (Czarniawska, 2007; Hine, 2007). Dette innebærer både å sitte og observere i klasserommet, å hjelpe læreren å dele ut ark, å snakke med eller hjelpe elever, eller å rydde søppel i skolegården sammen med elever samt spise lunsj på lærerrommet eller gå ute i friminuttet. Forskeren er i denne situasjonen ikke nødvendigvis nøytral; men deltar aktivt med den hun/han er (Cunliffe \& Karunanayake, 2013; Reed-Danahay, 2017; Taguchi, 2012). Hensikten er å få innsyn i samhandling i klasserommet under betingelsene for forskerens tilstedeværelse og observasjon. ${ }^{9}$ Jeg har også foretatt semistrukturerte intervjuer av lærere og avdelingsleder underveis (Holstein \& Gubrium, 1995; Kvale \& Brinkmann, 2010). Innsamlingen ble foretatt over en periode på til sammen ca. to måneder. Forskningsetiske retningslinjer utarbeidet av NESH (2016) ${ }^{10}$ følges, og prosjektet er godkjent av Norsk Samfunnsvitenskapelige Datatjeneste.

Det empiriske materialet fra de kvalitative undersøkelsene er observasjonsnotater og transkripsjoner av lydopptak fra intervjuer. Datamaterialet er analysert i grovkategorier som deretter har blitt analysert induktivt med tematisk innholdsanalyse (Bryman, 2012, s. 297-298; Taguchi, 2012).

9 Reed-Danahay (2017), Cunliffe og Karunanayake (2013) og Taguchi (2012) ser kritisk på forskerens deltakelse. Disse tar avstand fra såkalt «nøytral» deltakelse i forskning. A observere vil innebære ulike og varierende relasjoner med informanter, og som også påvirker analysene. Forskeren både deltar, påvirker, og tar fram ulike ressurser i sitt møte med informantene - på samme tid som forskeren påvirkes av feltet. Forskerens identitet er ikke én objektiv som observerer kontrollert, men kan utvikle seg i relasjon til informantene. Cunfliffe og Karunanayake argumenterer for at dette ikke nødvendigvis er en svakhet ved studien; snarere er det et vitenskapsteoretisk spørsmål som berører observasjon og objektivitet som sådan, og hvorvidt dette er mulig - eller ønskelig. Dette gir forskeren en rekke identiteter å håndtere. Et slikt syn på forskeren vil ha sammenheng med analysestrategien, som ser etter påvirkningsfaktorer og mulige identiteter og handlingsrom hos elevene. https://www.etikkom.no/forskningsetiske-retningslinjer/Samfunnsvitenskap-jus-og-humaniora/ Lesedato: 05.06.19. 
I analysen hadde jeg blikk for næranalyser hvor både folk og materielle faktorer kunne spille inn. Da jeg leste materialet, koplet jeg på noen teoretiske ledetråder fra Deleuze og Guattaris situasjonsbestemte etikk. I dette kapittelet viser jeg kun to situasjoner fra materialet. Å snevre inn fokus slik, gjør det mulig å gå nærmere aktørene i klasserommet og få fram det komplekse spillet mellom mennesker, ting og ord og hvordan bestemte former for verdighet skapes. Analysen gjenspeiler likevel noen nøkkelfunn som jeg også ser i resten av datamaterialet.

I det neste vil jeg vise eksempel på en analyse av verdighet hos nyankomne i introduksjonsklasser. Jeg vil ha to praktiske hovedfokus i analysen: Jeg vil jeg se etter hvem og hva som kan betegnes som viktige faktorer i en hendelse. Deretter vil jeg analysere og drøfte hvilke muligheter, begrensninger og handlingsrom ulike deltakere til sammen skaper for de nyankomne elevene.

\section{Verdighet i introduksjonsklassen: Hospitering, friminutt og lærerens peptalk}

Introduksjonsklassen jeg får besøke, har en særegen og optimistisk stemning i klasserommet. De fleste elevene har vært i introduksjonsklassen i 6-9 måneder. Elevene er svært forskjellige, både når det gjelder boforhold, hvorvidt de er enslig mindreårige flyktninger eller barn av arbeidsinnvandrere, hvorvidt de er faglig sterke, svake, eller kanskje heller ikke har lært å lese ennå. Elevene hjelper hverandre, støtter hverandre, oversetter for hverandre underveis. Både lærere og elever i introduksjonsklassen uttrykker god stemning og relasjoner preget av trygghet, anerkjennelse og trivsel gjennom gjensidig bekreftende ord, smil og humor. Lærerne synes dyktige på å utfordre elever både sosialt, faglig og praktisk, og både elever og lærere omtaler hverandre med varme og engasjement, og konflikter er ofte kortvarige.

I utdraget jeg nå presenterer, foregår det imidlertid noe som bryter med denne idylliske skolehverdagen. Skoleåret nærmer seg slutten. Med forbehold om tilstrekkelige norskkunnskaper skal de aller fleste elevene over i ordinært skoletilbud. Oppbruddet står for døren, noe som særlig kommer til uttrykk i et friminutt og i en peptalk mellom norsklæreren og elevene. 


\section{Hendelse 1: Elevsamtale i et friminutt}

Det er friminutt. Denne dagen er det mange ledige stoler og bord, og det er rikelig med lærere. Seks av ca. tjue elever er til stede. Jeg får beskjed om at de andre elevene er på «hospitering». Hospitering innebærer at de andre er ute i andre klasser på skolen, og følger sine trinn. Hospitering er ment som en overgang mellom introduksjonsklassen og ordinært skoletilbud. Når elevene har tilstrekkelig med norskkunnskaper, overføres de til sine lokale skoler. Hospitering kan vare alt fra én dag til én uke.

Ei somalisk jente sitter og skriver på telefonen sin bakerst i klasserommet. Jeg står ved siden av og studerer noen plakater elevene har laget. En annen elev, afghanske Alan, kommer mot oss. Han henvender seg til henne, og til meg. Alan sier: «Du har vært på hospitering, ass! Hvorfor skal ikke jeg hospitere? Hun hospiterer», sier han til meg. «Vi kom samtidig». Jenta smiler og ser ned, sier ikke noe. Alan fortsetter, gjentar: «Hun er på samme [gruppe] som meg». Han går.

\section{Hendelse 2: Peptalk mellom lærere og elever}

Det er norsktime, men det er en del tomme pulter i klasserommet. Cirka halvparten av elevene er ikke til stede, og det blir sagt at de er på hospitering. Timen starter. En norsklærer står foran, og inn kommer nå også avdelingsleder. Læreren forklarer at avdelingslederen nå har kommet av en grunn. Det er også en grunn til at de har samlet denne gjengen med elever akkurat nå. Det handler om hospitering. «Det er mange som vil hospitere», sier læreren. Det er helt stille i rommet. (Jeg tror umiddelbart at alle som er i rommet skal få hospitere.) Hun og avdelingsleder vil nå si at de som nå er igjen i klasserommet, ikke skal hospitere. Det er helt stille i klassen.

Læreren tar ordet videre og snakker om vanlig klasse. Hun sier at det faglige nivået $\mathrm{i}$ vanlig klasse er mye høyere. Hun forteller at hun ville gitt en vanlig klasse i oppgave å analysere Henrik Ibsen. Hun sier at de snakker fortere der. At hun og avdelingsleder vurderer «hva vil dere lære mest av. Hvor mye språk kan dere, hvor mye kan dere fag. Det krever sjefene». Læreren sier at de skal bruke tiden som er igjen, det er fire uker, til å jobbe hardt. Hun sier at de må bli kjent med vanlig ungdom. Læreren gir konkrete tips til møtesteder, som leksehjelp og ungdomsklubber. Hun 
sier også at de skal snakke mye norsk, og at de skal låne norske bøker på biblioteket, og se norsk TV.

Læreren sier i undervisningen at det er så mye de ikke kan lære dem. At det er en umulig oppgave. Men hun skal lære dem så mye hun kan i tiden som er igjen. «Innsats, innsats, innsats er det som er viktig.»

Elevene kommer med forslag til hva de kan lære. Noen er ivrige og foreslår at de skal lære 10 ord hver dag, og ha diktat hver dag. Noen vil lære forskjellen på «i» og «på». De skal også øve på å være muntlige. «Hva skal vi snakke om?», spør læreren. «Å være norsk. Om Norge», sier elevene. Ei jente foreslår at de kan se en kort film og bruke ordene videre om det temaet. Læreren vil at de skal jobbe med strategier for tekster med ukjente norske ord.

I etterkant av timen snakker en annen lærer engasjert i friminuttet om det å bli en del av det norske samfunnet. «Det er som et fjell», sier hun. Hun er bekymret.

\section{Verdighet som handlingsrom i introduksjonsklasser: En posthuman lesning}

Observasjonsmaterialet viser mange indikatorer på at elevene trives i introduksjonsklassen, og at lærere møter elevers behov på profesjonelt og adekvat vis. Imidlertid gir eksemplene innsyn i noen avgjørende hendelser i klasserommet som utgjør etiske dilemma, som setter søkelys på ungdommenes verdighet.

En viktig hendelse denne skoledagen handler om det å hospitere. Hospitering representerer mer enn en praktisk ordning med prøvedager i et ordinært skoletilbud. Når elevene kommer på skolen denne dagen, er det en rekke tomme stoler. Lærere sier straks til meg at det er så mange tomme stoler fordi det er mange som er på hospitering. Tomme stoler og det fysiske fraværet av elever skaper stor oppmerksomhet hos elevene. De tomme stolene kommenteres flere ganger, blant annet fra eleven i friminuttet og også av læreren og avdelingslederen i skoletimesamtalen. Alan benytter friminuttet til å sette ord på frustrasjonen over ikke å ha blitt valgt ut til hospitering; det er tydelig at dette er noe han er engasjert i. Han gir uttrykk for at han gjerne skulle ha hospitert. I denne korte hendelsen 
jeg refererer gir Alan uttrykk for at hospitering en slags ønsket status, men også en status og identitet han selv ikke får del i. Det synes også som at hospitering har blitt oppfattet som en slags «premie» for deltakelse der han er, og også en del av en slags konkurranse med medelever. Samtidig virker det som om kriteriene for å få hospitering er tilslørt, både i det at andre kommer før ham - men også at medeleven (og forsker) ikke svarer stort når han spør. Stolene er tomme, forklaringene uteblir. Det er stille.

Med Deleuze og Guattari kan man si at de tomme stolene skaper et dreiepunkt for denne skoledagen. Fraværet av de hospiterende elevene og tomme stoler framstår som en skillelinje, et momentum - en «event». Skillet går mellom de elevene skolen definerer som klare for å hospitere de «verdige» - og dem som blir igjen. De elevene som er til stede i klasserommet, får i stedet en status av en ikke-væren. De er ikke klare eller ikke verdige ordinært tilbud. Overgangen ved hospitering gjøres til en nødvendig og ettertraktet rite. Når noen elever ikke får hospitere og delta i denne riten skapes det et vakuum. Alan forteller at andre får hospitere, selv om det er på samme gruppe og har vært der like lenge. Han vil gjerne bryte opp, men kriteriene for å bli verdig de ordinære klassene, er ikke klare. Alan opponerer mot det som virker som en fastlåst standard. Han forteller dette i friminuttet, og til forskeren og en annen elev. Kanskje det er enklere å snakke fritt i friminuttet, og kanskje er det med hensikt å fortelle om det han opplever som urettferdig og uklart til noen som ikke er lærere, og er utenfor systemet.

Hospitering knyttes også ofte opp mot bruk av tid. Lærere bruker framtid i talen for elevene. Tiden blir en del av et bestemt dramaturgisk skript. For det første har læreren en peptalk om den siste måneden, angir antall uker og nevner «tiden som er igjen», eller snakker om tilværelsen «der framme» flere ganger. For det andre knyttes tid opp mot følelser og en slags desperasjon. Læreren sier at de har «dårlig tid», og at hun har så mye hun ville ha lært dem, men at det er kort tid igjen i introduksjonsklassen. Læreren sier også at det å lære dem alt - altså språket - er «helt umulig» på grunn av tiden. Dette skaper bestemte reaksjoner og handlinger hos elevene. Elevenes reaksjon er å foreslå en rekke konkrete aktiviteter, som for eksempel å se på bilder og film om Norge eller å lære en mengde norske gloser i hjemmelekse hver uke. 
For det tredje har tidsaspektet lenger fram også en bestemt følelsesmessig valør. Å være i en ordinær skole beskrives som faglig vanskelig ved at det gis eksempler på litteratur (Ibsen) som de fleste ungdommene ikke har noen forkunnskaper til å vite noe om. Læreren gir praktiske eksempler på hvordan andre lærere snakker mye fortere, med en undertekst av at dette er noe elevene ikke greier å gjøre nå.

Å klare norsk skole beskrives også med en metafor: «Det er et fjell de skal over». Til sammen framstår tilværelsen der framme som praktisk vanskelig, som ukjent, abstrakt og bekymringsfull. Det bygges opp en skillelinje mellom det de er nå, en slags ikke-tilværelse, og det de skal bli, som er såkalt «vanlige».

Nettopp begrepet «vanlig» er påfallende. Ordet «vanlig» kommer fram i denne teksten, og settes i sammenheng med det å bli norsk. I lærerens peptalk med elevene forteller læreren hva elevene kan gjøre før de kan komme i vanlig klasse. Hun sier at de må oppsøke ungdomsklubber med vanlig ungdom eller leksehjelp; de bør snakke mye norsk og låne norske bøker på biblioteket, samt se norsk TV. Læreren gir dermed en oversikt over ulike muligheter til å kvalifisere som norsk. Å «være vanlig» kan på den ene siden beskrives en pragmatisk term for å beskrive forskjellen på å gå i introduksjonsklasse versus ordinært skoletilbud. Imidlertid kan det også hende at det vanlige kan sees i utvidet forstand i introduksjonsklassen. Læreren snakker om hospitering og det å bli overført til ordinært skoletilbud som «vanlig klasse», hun bruker begrepet «vanlig ungdom», at nivået $\mathrm{i}$ «vanlig klasse» er høyere. Dette kan oppfattes som at det «ekte» livet foregår der framme, der ute. Ikke nå og ikke i det som har vært.

\section{Hospitering og være vanlig - hva gjør dette med nyankomne ungdommers verdighet?}

Samtidig representerer det å bli vanlig også mangler og tomrom. Det skapes et vakuum ved de tomme stolene og i ledelsens avgjørelse om hvem som ikke får hospitere. Trykket blir forsterket når de blir presentert for kunnskapshull som elevene ikke har, og ytterligere i de normative bildene av den ideelle og vanlige ungdommen. Ungdommenes identitet og verdi settes i spill. I lærerens tale i skoletimen skilles det mellom hva ungdommene er 
nå og hva de skal bli. I utdraget forteller læreren om andre vanlige klasser, men også at ungdommene her bør bli vanlige. Dermed representerer «vanlig» en normativ form for verdighet som elevene ikke har. Lærere, elever, fysisk kontekst og tid i denne introduksjonsklassen driver fram statusen som «vanlig» som et dramaturgisk skille mellom væren og ikke-væren, der det å komme i vanlig klasse er helt avgjørende. Noe annet kan forstås som en umulighet, som en ikke-væren. For Alan representerer det å ikke få hospitere som et uforståelig brudd og en eksklusjon som han ikke vet hvordan han skal håndtere. Dermed blir det å være vanlig ikke bare en hverdagslig betegnelse, men i stedet noe som også elever og lærere markerer som mangel på likeverd. På den måten kan bruken av «vanlig» markere lite handlingsrom, eller i beste fall et svært styrt handlingsrom for å oppnå verdighet.

Ved siden av at hospitering og det å være «vanlig» framstår som tilfeldige praktiske handling og forklaringsmåter overfor elevene, kan man også si at de skaper en særegen dynamikk. Denne dynamikken oppstår mellom lærere og elever, i vakuumet av tomme stoler og hospiteringsklassene, mellom klasserom og verden der ute, og mellom tiltak her og nå - og en ukjent framtid. Verdighet blir et dynamisk begrep i situasjonen; det er en prosess og noe som spinnes fram til en status quo. Spørsmålet man så kan stille videre, er om det å være «vanlig» nødvendigvis er problematisk.

For å svare på dette vil det være fruktbart å se hva hospitering og det å være vanlig kan innebære for nyankomne ungdommer. Beskrivelsene fra klasserommet viser at bruken av ordet «vanlig» skaper en blanding av desperasjon og iver- og noen veier til handling. Både lærere og elever foreslår en rekke tiltak for å kunne klare overgangen til et ordinært skoletilbud. De får råd om at de skal se norsk film, se på bilder, snakke om Norge og lære seg norske ord og norsk grammatikk. Tiltakene er i stor grad realistiske og mulig å gjennomføre for mange av ungdommene. Det er ikke bare lærerne som løfter fram det å bli vanlig. Elevene blir ivrige, og har selv en rekke forslag for å få dette til.

Det neste spørsmålet er hvorfor handlingsrom kan være et etisk problem og et spørsmål om verdighet. Handlingsrommet hos nyankomne blir for det første et viktig etisk anliggende når verdighet som «vanlig» betyr at man befinner seg innenfor eller utenfor. For det er mulig å falle utenfor. Det å være «vanlig» knyttes opp mot hospitering, som er 
overgangsriten for dem som «får det til» og er innenfor. Alan gir uttrykk for en frustrasjon over ikke å forstå kriteriene for å få hospitere, og dermed også frustrasjon over mangelen på handlingsrom. For det andre etableres verdighet hos nyankomne ungdommer som om det er en fastsatt status. $\AA$ være vanlig representerer dermed det Guattari og Deleuze beskriver som en «majoritær» form for verdighet. Både lærere, elever, omgivelser, skoleledelse («sjefene» og avdelingsleder) bidrar. Det er i dette øyeblikket det å være «vanlig» blir problematisk. Ikke bare framstår vanlige klasser som en fastsatt status for verdighet. Det virker ikke som om det er noe alternativ for verdig deltakelse utenfor. Handlingsrommet hos ungdommer blir for alvor truet når det ikke å avfinne seg med disse fastsatte markørene, og alternative måter å være på, oppfattes som mangelfulle.

Imidlertid er det også et annet aspekt ved tid som også skaper utfordringer for handlingsrom, nemlig en gjennomgående mangel på fortid og nåtid. Det kan synes som om det blir lite rom for elevenes historie og ulike opplevelser fra tidligere - fortiden forsvinner. Det er også i liten grad snakk om hva elevene nå trenger ut fra sine styrker og sine utfordringer. En konsekvens kan være at mer minoritære identiteter og mangfoldet forsvinner. Historiene og forskjellene viskes ut og usynliggjøres. Elevers unike opplevelser, kontekster og kompetanser kommer i bakgrunnen og skaper på den måten også begrensninger for handlingsrom - og verdighet.

\section{Verdig = vanlig og norsk ? Når elever ikke er like mye verdt}

I et samfunn med økt mobilitet og mange nyankomne elever, er spørsmålet om menneskeverd avgjørende. I dette kapittelet spør jeg hva som kjennetegner verdighet for nyankomne elever i norsk skole. Beskrivelsene fra klasserommet viser at begrepene menneskeverd og likeverd er problematiske. En trygg, bekreftende tilværelse i introduksjonsklassen byttes ut med en ukjent framtid i ordinær klasse, og ungdommene oppfordres til hvordan de kan delta i det norske samfunnet og bli såkalt «vanlige». Satt på spissen står man igjen med likningen verdig = vanlig og norsk. For de nyankomne elevene synes standardene for deltakelse skyhøye og fastlåste. Samtidig er veien mot likeverd overgangsritene utilgjengelige 
og uklare. Både elever og lærere føler seg usikre på om elevene noen gang kommer til å nå opp mot idealet om å bli vanlig. Eksemplene fra dette klasserommet viser at begrepene verdighet og likeverd ikke fungerer som idealer. Alle elever i skolen er rett og slett ikke like mye verdt.

At elever ikke er like mye verdt er en oppsiktsvekkende påstand, og særlig for en skole som i stor grad definerer menneskeverd som en helt grunnleggende verdi og utgjør selve kjernen av skolens virksomhet. Dette er ikke en kritikk av lærernes jobb. Lærerne i dette tilfellet ble oppfattet som godt kvalifiserte og jobbet iherdig for å hjelpe elevene, både med energi og omsorg. Samtidig var lærerne en del av et slags maskineri som stiller høye krav for hva likeverd kan innebære, som også delvis satte dem ut av spill. Å mestre skolen krever ofte en sterk tilpasning til skolesystemets eksisterende mandat og diskurser (Bostad \& Løvlie, 2013). Dette eksempelet viser at både elever, lærere, skolens «sjefer», skolemiljø og rutiner kan fungere som selvforsterkende krefter i dette maskineriet. Mektige og ensrettede former for verdighet skapes, som ikke enkeltpersoner alltid synes å rå over. Ut fra argumentet om at menneskeverd er et begrep i støpeskjeen, og at det er sårbart for hva som foregår hver dag i klasserommet, stilles det høyere krav til skolen.

Det å utvikle standarder for inkludering kan på den ene siden tydeliggjøre kriterier, åpne for deltakelse i samfunnet og hjelpe elever inn i sosiale fellesskap på en konstruktiv måte (Bonanno, 2005). Tankegangen er at kompetansemål er ment som «inngangsporter til deltakelse på alle områder innenfor utdanning, arbeids- og samfunnsliv» (Kunnskapsdepartementet, 2017). Eksemplene fra klasserommet viser imidlertid på den andre siden at det å bli «vanlig» er et sårbart prosjekt, der de nyankomne kommer til kort. Det å mestre standardiserte mål i dette klasserommet blir ikke bare ønskelig, men selve målestokken for verdighet.

Kritikken av menneskeverd som «å bli vanlig» ligger ikke i at det finnes standarder eller kunnskapsmål i skolen. I stedet vil jeg hevde at problemet med «å være vanlig» har sitt opphav i selve forståelsen av begrepet menneskeverd. Det at skolen hevder at alle er like mye verdt, betyr ikke at elevene i praksis blir møtt eller får like muligheter. Selve begrepene for menneskeverd synes å svikte elevene og kan gi dem lite handlingsrom.

Det neste spørsmålet er hva som da kan ligge i begrepene menneskeverd. Den nye overordnede delen beskriver menneskeverd med utsagn 
som «menneskeverdets ukrenkelighet og at alle mennesker er like mye verdt, uavhengig av hva som ellers skiller oss». Den sier videre «at alle elever skal behandles likeverdig, og ingen elever skal utsettes for diskriminering» (Kunnskapsdepartementet, 2017). I møte med nyankomne i introduksjonsklassen yter ikke disse beskrivelsene av menneskeverd og likeverd rettferdighet mot den rå virkeligheten elevene står overfor. Abstrakte idealer, idealer som skal gjelde «alle», gjelder i praksis temmelig få. Den vestlige kultur har tradisjonelt lagt vekt på fornuft og selvstendighet som kjennetegn på hva et menneske er, som kan ledes tilbake til gresk antikk og til Kant - og som også ligger sterkt til grunn for dagens forståelse av menneskeverd og menneskerettigheter (Nussbaum, 2007). Skoleverkets lovverk og læreplaner bygger i stor grad på slike formuleringer, og kan framstå som mangelfulle. Med dette kapittelet og eksempelet med nyankomne elevers skolehverdag etterlyses en debatt og en videreutvikling av begrepsforståelsen menneskeverd og verdighet i skolen.

Som et bidrag til denne debatten vil jeg hevde at det er nødvendig med flere og mer dynamiske og praksisnære tilnærminger til verdighet for å oppnå inkludering i samfunnet. Inkludering og likeverd består ikke standarder for likhet. Som Edwards, Armstrong og Miller (2001) sier; «include me out.» Det er avgjørende at likeverd i skolen ikke baseres på likhet, men drives av like muligheter til å spille inn sine ressurser og behov. En dynamisk tilnærming til menneskeverd fremme en forståelse av elevenes mangfoldige ressurser og behov. For nyankomne handler ikke mangfold om et snevert fokus etnisk opprinnelse eller særlige kulturelle kjennetegn fra landet de reiste fra. Fokus på opprinnelse og kjennetegn kan kalles en såkalt essensialistisk og statisk forståelse av identitet og mangfold (Sayer, 1997). Nyankomne elever må i stedet forstås som åpne systemer som bærer med seg fortid, nåtid og framtid, hevder Pastoor (2016). Dette handler ikke om at ikke det er viktig å lære norsk, som er et viktig premiss for å delta i samfunnet. I stedet utfordres skolen til menneskeverd som rommer de vanskene, historiene, interessene og ressursene som elevene er klare til å «legge i potten» her og nå.

En dynamisk forståelse av verdighet vil for det andre kunne innebære en $ø$ kt sensitivitet for ungdoms ressurser og behov. Å involvere 
elevenes ulike behov betyr ikke det samme som å bare fokusere på vanskene deres. Et vanskefokus kan svekke nyankomnes evne til å klare seg på ulike sosiale arenaer (Schultz, 2016). I stedet rettes fokus mot det personlige møtet med elevene og anerkjennelsen som gis (Margalit, 2001).

En dynamisk tilnærming spiller for det tredje på en ansvarliggjøring av skolen og læreren i møte med elevene. Eksempelet med nyankomne viser at elever, lærere og skolemiljø til sammen er en del av et slags maskineri som skaper en bestemt forståelse av menneskeverd. Imidlertid peker også denne analysen på at lærere utgjør en reell forskjell for elevers menneskeverd. Overordnet del i den nye læreplanen gir noen antydninger til andre verdighetsforståelser som det er verdt å merke seg. «Elevene skal også gis likeverdige muligheter slik at de kan ta selvstendige valg» (Kunnskapsdepartementet, 2017). Verdighet kan altså være noe som gis, og er en praktisk og hverdagslig handling. I skolen foregår dette daglig - men som begrep er denne forståelsen av menneskeverd taust, uutforsket og heller ikke debattert i skolen. En dynamisk tilnærming til menneskeverd kan derfor bety å møte behov, legge til rette for elevene tar valg og gi elevene handlingsrom ut fra egne ressurser. Det retter blikket mot verdighet som oppstår i hverdagen, og stiller skolen og læreren til ansvar, ikke bare for resultater og kunnskapsmål, men til å utvikle menneskeverd som en øyeblikkets pedagogikk. Med Deleuze (1990; Rajchman, 200o, s. 96) handler derfor utfordringen om lærerens tilstedeværelse: Det er om å gjøre ikke å være uverdig de hendelsene som utgjør livet.

\section{Forfatterbiografi}

Ingrid Reite Christensen er førsteamanuensis i pedagogikk og spesialpedagogikk ved Universitetet i Sørøst-Norge. Hun forsker på mangfold, demokrati og medborgerskap, livsmestring og psykososial helse i skolen og profesjonslæring. Hun leder for tiden også internasjonale prosjekter om demokrati og medborgerskap og elevsentrert undervisning. Feltet hennes er tverrfaglig, der fellesnevneren er profesjon, medvirkning og mangfold i skolen. 


\section{Referanser}

Afdal, G., Røthing, Å. \& Schjetne, E. (2014). Empirisk etikk i pedagogiske praksiser. Artikulasjon forstyrrelse ekspansjon. Oslo, Cappelen Damm Akademisk.

Bansak, K., Hainmueller, J. \& Hangartner, D. (2016). How economic, humanitarian, and religious concerns shape european attitudes toward asylum seekers. Science 354: 217.

Barad, K. (2003). Posthumanist performativity: Toward and understanding of how matter comes to matter. Signs 28: 801-831.

Bonanno, G. A. (2005). Resilience in the Face of Potential Trauma. Current Directions in Psychological Science 14(3), 135-138.

Bostad, I. \& Løvlie, L. (2013). Deliberative democracy and moral disturbance. I S. Bergan, I. Harkavy \& H. Van't Land. Reimagining democratic societies. (s. 89-108). Strasbourg: Council of Europe Publishing.

Bryman, A. (2012). Social research methods. Oxford/New York: Oxford University Press.

Cunliffe, A. L. \& Karunanayake, G. (2013). Working within hyphen-spaces in ethnographic research. Implications for research identities and practice. Organizational Research Methods 16(3), 364-392.

Czarniawska, B. (2007). Shadowing and other techniques for doing fieldwork in modern societies. Liber, Malmö: Copenhage Business School Press.

Deleuze, G. (1990). The logic of sense. New York: Columbia University Press.

Deleuze, G. (2009). The logic of sense. New York: Continuum.

Deleuze, G. \& Guattari, F. (1994). What is philosophy? London, New York: Verso.

Edwards, R., Armstrong, P. \& Miller, N. (2001). Include me out: Critical readings of social exclusion, social inclusion and lifelong learning. International Journal of Lifelong Education 20(5), 417-428.

Eide, K. \& Broch, T. (2010). Enslige mindreårige flyktninger. Kunnskapsstatus og forskningsmessige utfordringer. Oslo: Regionsenter for barn og unges psykiske helse, region øst og sør.

Flyvbjerg, B. (2011). Making social science matter. Why social inquiry fails and how it can succeed again. Cambridge: Cambridge University Press.

Hine, C. (2007). Multi-Sited ethnography as a middle range methodology for contemporary STS. Science, Technology, \& Human Values 32(6), 652-671.

Holstein, J. A. \& Gubrium, J. F. (1995). The active interview. Newbury Park, CA: Sage. Kvale, S. \& Brinkmann, S. (2010). Det kvalitative forskningsintervju. Oslo: Gyldendal Akademisk.

Kant, I. (1785/1998). Groundwork of the metaphysics of morals. Cambridge: Cambridge University Press. http://dx.doi.org/10.1017/cbo9780511809590.004

Lysaker, O. (2015). Å leve et menneskeverdig liv - Martha Nussbaums globale helseetikk. Etikk i praksis. Nordic Journal Of Applied Ethics 9(2), 53-70.

Margalit, A. (2001). Privacy in the decent society. Social Research 68(1), 255-268. 
Matthews, J. (2008). Schooling and settlement: refugee education in Australia. International Studies in Sociology of Education 18(1), 31-45.

Mollica, R. F., Cardozo, B., Osofsky, H. J., Rafael, B. Ager, A. \& Salama, P. (2004). Mental Health in Complex Emergencies. The Lancet 364, 2058-67.

Neumayer, S. M., Skreslett, A. Borchgrevink, M. C. \& Gravråkmo, S. (2006). Psykososialt arbeid med flyktningbarn. Introduksjon og fagveileder Oslo, NKVTS.

Nilsen, T., Bjørnsson, J. K. \& Olsen, V. (2018). 7. Hvordan har likeverd i norsk skole endret seg de siste 2oårene? Tjue år med TIMSS og PISA $i$ Norge: 150-172.

Nussbaum, M. C. (2007). Frontiers of justice: disability, nationality, species membership. Cambridge, Mass.: Belknap Press of Harvard University Press

Opplæringslova (1998). Lov om grunnskolen og den vidaregåande opplæringa (LOV-1998-07-17-61).

Pastoor, L. d. W. (2013). Delaktighet och utanförskap. I M. Bak \& K. v. Brömssen. Barndom och migration. (s. 305-331). Umeå: Boréa Bokförlag.

Pastoor, L. d. W. (2016). Enslige unge flyktningers psykososiale utfordringer: behovet for en flyktningkompetent skole. I C. Øverlien, M. I. Hauge \& J.-H. Schultz. Barn, vold og traumer. Møter med unge i utsatte livssituasjoner. (s. 200-219). Oslo: Universitetsforlaget.

Perumal, J. (2015). Responding with hospitality: Refugee children in the South African education system. Education as Change 19(3), 65-90.

Rajchman, J. (2000). The Deleuze connections. Cambridge, MA, London, UK: The MIT Press.

Reed-Danahay, D. (2017). Participating, observing, witnessing. I S. Coleman, S. B. Hyatt \& A. Kingsolver. The Routledge Companion to C.ontemporary Anthropology. (p. 57-71). London, New York: Routledge.

Riege, A. (2003). Validity and reliability tests in case study research: a literature reivew with «hands-on» applications for each research phase. Qualitative Market Research 6(2).

Roald, T. \& Køppe, S. (2009). Generalisering i kvalitative metoder. Psyke \& Logos 29: 86-99.

Rutter, J. (2006). Refugee children in the UK. Maidenhead: Open University Pres.

Sayer, A. (1997). Essentialism, Social Constructionism, and beyond. The Sociological Review 45(3), 453-487.

Schultz, J.-H., Marshall, L., Norheim, H. \& Al-Shanti, K. (2016). School-based intervention in ongoing crisis: Lessons from a psychosocial and trauma-focused approach in Gaza schools. Journal on Education in Emergencies 2(1), 142-156.

Sørensen, E. (2009). The materiality of learning: Technology and knowledge in educational practices. Cambridge: Cambridge University Press.

Taguchi, H. L. (2012). A diffractive and Deleuzian approach to analyzing interview data. Feminist Theory 13(3), 265-281. 
Tamsin, L. (2011). Deleuze and Guattari's immanent ethics: Theory, subjectivity and duration. Albany: State University of New York Press.

Taylor, C. (1989). Sources of the Self: The making of the modern identity. Cambridge, MA: Harvard University Press.

Vesterdal, K. (2016). The roles of human rights education in Norway: A qualitative study of purposes and approaches in policy and in upper secondary schools. Tronheim: NTNU Trondheim.

Winter, S. L. (1994). Human values in a postmodern world. Yale Journal of Law and the Humanities 6(2), 233-248. 



\title{
Menneskeverd - Utviklingshemming - Skole
}

\section{Verdighet som grunnlag for pedagogisk praksis}

\section{Lena Lybæk}

Universitetet i Sørøst-Norge

\section{Åse-May Svendsen}

\author{
Billingstad skole, Asker kommune
}

\begin{abstract}
This article aims to discuss questions about dignity and children with cognitive disabilities (named mental retardation in ICD-10), with questions about inclusive or segregated education. In the first part of the article we discuss theoretical approaches to dignity. Traditional understandings of dignity are based in enlightenment humanism with its focus on autonomy and reason, or on dignity achieved through the cultivation of virtues. We discuss different approaches to inclusive notions of dignity. First, we discuss approaches that take their point of departure in vulnerability, and mutuality in human relationships, exemplified by Eva Kittay, Alasdair MacIntyre, and Martha Nussbaum. Subsequently, we present approaches that emphasize the singularity of the human being and upholding human rights as the basis for human dignity, exemplified by Avishai Margalit and Julia Kristeva. In the second part of the article, we discuss how five experienced teachers speak about dignity and pedagogical practice with children with cognitive disabilities. We point to how both integrated and segregated practices in schools are justified in and may be connected to different theories of dignity.
\end{abstract}

Keywords: Dignity, cognitive disabilities, inclusive education, vulnerability, singularity, human rights, CRPD

Tradisjonelle definisjoner av menneskeverdet utfordres i møte med mennesker med nedsatt kognitiv funksjonsevne. Menneskeverdet danner i FNs menneskerettighetserklæring grunnlaget for

Sitering av denne artikkelen: Lybæk, L. \& Svendsen, Å.-M. (2019). Menneskeverd - Utviklingshemming Skole: Verdighet som grunnlag for pedagogisk praksis. I Å. Valen-Sendstad \& I. R. Christensen (Red.), Menneskeverd - en utfordring for skole og samfunn (Kap. 3, s. 63-98). Oslo: Cappelen Damm Akademisk. https://doi.org/10.23865/noasp.9o.ch3.

Lisens: CC BY-NC 4.0. 
menneskerettighetene. Menneskerettighetsinstrumenter betegner det som noe iboende som kjennetegner hvert enkelt menneske. Videre forbinder erklæringens første artikkel menneskeverdet med egenskaper som frihet, fornuft og samvittighet. Slike definisjoner av menneskeverd framhever sentrale idealer i et humanistisk menneskesyn, men fungerer samtidig til å utelukke personer med nedsatt kognitiv funksjonsevne fra menneskeverdet (Carlson, 2010; Davy, 2015; Griffin, 2010). De legger vekt på egenskaper og ferdigheter som utviklingshemmedes funksjonsnedsettelser berøres av.

Ideen om menneskeverdet danner også verdigrunnlaget for skolens virksomhet. Lærerprofesjonens etiske plattform framhever menneskeverdets ukrenkelighet som grunnleggende verdi. Skolen skal fremme likeverd og verne barn mot krenkelser: «Diskriminering skal ikke forekomme» i skolen (Utdanningsforbundet, udatert). Allikevel viser studier at opplæringstilbudet til barn med utviklingshemming er mangelfullt. Barn med utviklingshemming utgjør den største andelen av elever som mottar spesialundervisning (NOU, 2016, s. 17). De mottar en stor del av undervisningen utenfor det ordinære klasserommet, og kvaliteten i opplæringen de mottar er mangelfull (Bachmann, Haug \& Nordahl, 2016; Barneombudet, 2017).

Konvensjonen om rettighetene til personer med nedsatt funksjonsevne (CRPD) fastslår i artikkel 24 retten til inkluderende opplæring. FNs komite for CRPD framholder at inkluderende opplæring som prinsipp «respekterer [alle elevers] iboende verdighet og rett til å bestemme over seg selv,» skal motvirke diskriminering og bidra til inkludering i samfunnet som helhet (UN, 2016, s. 4, punkt 10 b.). Studier viser imidlertid en økende grad av segregert opplæring i norsk skole (Bachmann et al., 2016; Wendelborg \& Tossebro, 2008; Wendelborg \& Tøssebro, 2011). Hausstätter (2013) forklarer dette med motsetningen mellom spesialpedagogikkens grunnleggende verdier om barnets egenverd og den dominerende politiske forståelsen av utdanning som nasjonal investering, sammen med krav om effektivisering i skolen.

Mennesker med utviklingshemming synes derfor ikke å inneha samme status som andre mennesker. Selv om både menneskeverdet som ide, og skolen som institusjon ideelt sett gjelder alle, synes elever med utviklingshemming å verdsettes i mindre grad enn andre elever, - de er unntak. 
I denne artikkelen drøfter vi spørsmål om verdighet eller menneskeverd og barn med utviklingshemming i sammenheng med spørsmål om inkluderende eller segregerende opplæring. Menneskeverdet anses som en grunnleggende idé for en etisk pedagogisk praksis, men hva består dette menneskeverdet i? Hvem gjelder verdigheten, og hvem har del i den? Vårt anliggende er både teoretisk og praktisk. Verdighetsbegrepets innhold settes på prøve av mennesker med nedsatt kognitiv funksjonsevne. Likeledes blir utfordringer knyttet til den praktiske realiseringen av verdigheten tydelig i møte med mennesker med utviklingshemming.

Vi har vært interessert i å se nærmere på inkluderende forståelser av menneskeverdet, og hvordan ulike forståelser av verdighet kommer til uttrykk i pedagogisk praksis i møte med barn som har utviklingshemming. Hensikten er å utforske verdighetsbegrepets mulige anvendelse og betydning i to sammenhenger som både inkluderer og ekskluderer (diskriminerer) barn med nedsatt kognitiv funksjonsevne: For det første, menneskeverdet som en idé som på den ene side gjelder alle mennesker, men som i utleggelser om hva det innebærer, definerer utviklingshemmede ut. For det andre, skolen og utdanning som dannende og formende institusjoner som skal favne alle, og spesialundervisningens identifisering av avvik og målsetting om habilitering av den enkelte. Vår problemstilling er derfor:

Ideen om menneskeverdets ukrenkelighet og likebehandling som grunnleggende verdier for skolen tatt i betraktning: hva er verdighetsbegrepets mulige innhold og betydning som utgangspunkt for pedagogisk praksis i møte med utviklingshemmede? Hvilke verdighetsforståelser kommer til uttrykk i læreres refleksjoner knyttet til inkluderende og segregerende tiltak i skolen?

Ved å drøfte inkluderende tilnærminger til verdighetsbegrepet i sammenheng med læreres egne refleksjoner, ønsker vi å bidra til en bevisstgjøring av verdighetsbegrepets praktiske betydning som et kritisk ideal for skolens praksis. I et innledende avsnitt viser vi hvordan tradisjonelle forståelser av verdighet i deres fokus på konkrete individuelle egenskaper ekskluderer mennesker med utviklingshemming. Deretter utforsker vi ulike inkluderende tilnærminger til verdighet. Sårbarhet og gjensidighet i mellommenneskelige relasjoner er utgangspunkt for et verdighetsbegrep 
som søker å opprettholde en sammenheng mellom allmennmenneskelige egenskaper og bekreftelse av individet som en del av et menneskelig fellesskap. Videre ser vi på tilnærminger som legger vekt på enkeltmenneskets unike erfaringer og egenskaper, og menneskerettighetene som forutsetning for et liv i verdighet. Felles for alle disse tilnærmingene er en forståelse av at menneskeverdet beskyttes av, eller realiseres i, fellesskap med andre. I artikkelens andre del setter vi verdighetsbegrepet i sammenheng med læreres refleksjoner om pedagogisk praksis i møte med barn med utviklingshemming. Selv om inkluderende opplæring er et ideal, beskriver lærerne en virkelighet der valget står mellom integrering eller segregering av elever med utviklingshemming $\mathrm{i} /$ fra ordinære klasserom. I valget synes disse lærerne å foretrekke segregering som den beste måten å ivareta alle elevers verdighet.

\section{Framgangsmåte, utvalg og utforming av artikkelen}

Den første delen av denne artikkelen er en teoretisk og kritisk refleksjon, ledet av spørsmålet: «Hva er et inkluderende verdighetsbegreps mulige innhold og betydning?» Her beskriver vi først hvordan ideen om menneskeverd både har virket transformerende og marginaliserende for personer med utviklingshemming. Deretter utforsker vi teoretiske tilnærminger til verdighet som fokuserer på personer med funksjonsnedsettelser og i motsetning til tradisjonelle tilnærminger, ikke tar utgangspunkt i rasjonalitet og autonomi. Utvalget av teoretiske tilnærminger i denne delen begrenses naturlig nok av artikkelformatets omfang. Utgangspunktet for utvalget har vært ønsket om å finne inkluderende forståelser av verdighet. Det vil si ansatser til verdighetsbegrepet som formidler interesse for utviklingshemmedes likeverdige status og deltakelse. Vi har også søkt tilnærminger som gjennom en beskjeftigelse med rettigheter, rettferd og deltakelse implisitt drøfter hva det betyr å være menneske, og derfor formidler en forståelse av verdighet. I analysen av disse har vi søkt forfatternes forståelse av kognitive funksjonsnedsettelser, deres beskrivelse av forholdet mellom utviklingshemmede og andre mennesker, og tanker om utviklingshemmedes plass og mulighet for deltakelse i samfunnet. 
I den andre delen vender vi oss til fem erfarne læreres refleksjoner. Med utgangspunkt i skolens formålsparagraf og lærerprofesjonens etiske plattform spør vi: «Hvordan snakker disse lærerne meningsfylt om mulighetene for inkluderende pedagogiske praksiser, og hvilke forståelser av verdighet kommer til uttrykk i disse erfaringene og refleksjonene? Er verdighet et begrep som anvendes, og hvordan?» Inkluderende opplæring er relevant i sammenheng med spørsmål om verdighet og utviklingshemming, fordi begge gir uttrykk for et ideal om å favne alle: Verdighetsbegrepet i forbindelse med menneskerettighetsdiskurser, og inkluderende opplæring i sammenheng med pedagogisk praksis.

Med utgangspunkt i en konstruktivistisk kunnskapsforståelse, tenker vi på samtalene med lærerne som «aktive fortolkende» anledninger for meningsskaping og kunnskapsutvikling (Holstein \& Gubrium, 2003, s. 68), der begge samtalepartnere bidrar til forståelse og refleksjoner rundt et gitt tema. Samtalene og innholdet i dem er situerte. De er betinget av samtalepartnernes egne erfaringer med, engasjement for, og hvordan de er påvirket av spørsmålet om verdighet og inkluderende/segregerende opplæring. Samtalenes validitet ligger i at de evner å formidle konkrete og reelle erfaringer som bidrar til kunnskap om, og grunnlag for, videre drøfting av verdighetsforståelser (Holstein \& Gubrium, 2003, s. 71). Lærernes eksempler og refleksjoner er deres egne, men gir altså grunnlag for en diskusjon om sammenhengen mellom pedagogisk praksis og verdighetsforståelser. De gir grunnlag for analytiske generaliseringer på den måten at lærernes utsagn som eksempler generaliseres analytisk til teori.

Vi var konkret interessert i verdighet som grunnleggende verdi for en etisk pedagogisk praksis. Derfor var det naturlig for oss å søke målrettet etter samtalepartnere som kunne bidra med sin erfaring og kunnskap knyttet til pedagogisk praksis i møte med barn med utviklingshemming. «Vi» er i dette tilfellet en spesialpedagog og lærer med erfaring fra arbeid med barn med utviklingshemming fra ulike skoleslag, og en forsker med fokus på menneskerettigheter, flerkultur og inkludering i skolen, som også er mor til to barn med kognitive funksjonsnedsettelser. Vi kontaktet fem erfarne lærerne med invitasjon til samtaler og felles refleksjon om temaet verdighet og inkluderende opplæring. Lærerne har til felles at de har minst femten års praksis som lærere i skoler på Østlandet. Tre 
av dem har arbeidet $\mathrm{i}$ en kommune som både har et segregert system og et semi-segregert system. Det vil si at kommunen har en spesialskole for barn med utviklingshemming, men at den også har skoler der barn med utviklingshemming tilhører en klasse. Barnet er da sammen med denne i praktiske fag, men har mesteparten av sin undervisning i en spesialenhet/forsterket enhet på skolen. En av lærerne har ikke spesialpedagogisk utdanning, og har arbeidet på forskjellige skoler i ordinær undervisning, til dels med elever med spesielle behov i klassen. De øvrige lærerne har spesialpedagogisk utdanning. Lærerne har arbeidet med elever både i semi-segregerte klasser, og med elever på spesialskole.

Formålet med samtalene var å utforske sammenheng mellom pedagogisk praksis og forståelser av verdighet. Samtalene hadde form av aktive semistrukturerte intervjuer. Samtykke til opptak av samtalene ble gitt muntlig, og lærerne fikk informasjon om hvordan vi ønsket å bruke intervjuene. Kun en av forfatterne gjennomførte intervjuene, mens forfatterne på forhånd utarbeidet en intervjuguide, der tema for samtalene ble definert. I tillegg til å samtale om lærernes forståelse av verdighet, knyttet vi temaet opp til lærernes definisjoner av et godt læringsmiljø, og konkret til spørsmål om inkludering, integrering og segregering av elever med utviklingshemming. Dette utdyper vi nærmere i andre del av artikkelen.

Vår tilnærming i begge delene av denne artikkelen er først og fremst humanistisk. Den er preget av en fortolkende tradisjon og hensikten er å undersøke, reflektere over, og kritisk drøfte alternative måter å tenke verdighet på, også i lys av læreres erfaringer i arbeid med personer med utviklingshemming. Vår hensikt i denne artikkelen er altså ikke å rapportere empiriske data, som vi siden setter i sammenheng med eksisterende teori. Dette er heller ikke en pedagogisk undersøkelse. Vi forstår språk og praksis i tråd med konstruktivistisk/diskursteoretisk tradisjon, både som uttrykk for og definerende av virkelighetsoppfatninger, og diskurser som meningsbærende systemer som reflekterer sosiale (makt)strukturer. Vi forstår verdighetsbegrepet som et begrep som innenfor en vestlig idehistorisk tradisjon berører grunnleggende forståelser av hva det vil si å være menneske, og som et begrep som er forstått som universelt - noe som gjelder alle mennesker. En inkluderende verdighetsforståelse vil etter vårt 
skjønn fylle begrepet med et innhold som rommer menneskelig mangfold og oppleves gyldig for hvert enkelt menneske. Denne artikkelen er derfor framfor alt utforskende og reflekterende, der teoretiske konstruksjoner av verdighetsbegrepet analyseres, og dets innhold og betydning som utgangspunkt for pedagogisk praksis i møte med utviklingshemmede drøftes. Samtalene med lærerne i artikkelens andre del kan anses som en meningsskapende øvelse i seg selv, som står i dialog med og supplerer teoretiske tilnærminger som analyseres i den første delen av artikkelen. Som utgangspunkt for disse drøftingene vender vi oss først til en konkretisering av hva utviklingshemming innebærer, og på hvilken måte tradisjonelle forståelser av menneskeverdet marginaliserer utviklingshemmede.

\section{Utviklingshemming, menneskeverd og marginalisering}

Når det kommer til rettigheter, forståelser av menneskeverd og likeverd står utviklingshemming ${ }^{1} \mathrm{i}$ en særstilling og i en motsetning til andre funksjonsnedsettelser. Denne motsetningen knytter seg konkret til de begrensninger utviklingshemming medfører for individet kognitivt, kommunikativt, atferdsmessig og sosialt. Den berører også omgivelsene og de samfunnsstrukturer som er utviklet i respons til disse begrensingene. De individuelle begrensningene er forbundet med de egenskapene eller ferdighetene som ofte brukes for å definere det grunnleggende ved det å være menneske, noe alle mennesker besitter eller har i seg. I tradisjonelle teorier danner disse egenskapene grunnlag for menneskeverdet, og utgjør en forutsetning for en likeverdig deltakelse i samfunnet.

Utviklingshemming er ikke en enhetlig diagnose, og begrepet dekker mange ulike diagnoser og tilstander (Eknes, 2014; Mittler, 2003). Felles er at de innebærer ulike grader av begrensninger i intellektuell og kognitiv kapasitet $(I C D-10,2019)$. Begrenset evne til rasjonell og abstrakt tenkning påvirker også andre funksjoner («adaptive ferdigheter i

$1 \quad$ Vi velger å bruke betegnelsene utviklingshemming eller nedsatt kognitiv funksjonsevne heller enn den medisinske diagnosen psykisk utviklingshemming. Begrepet psykisk utviklingshemming er tvetydig (Eknes, 2014), og antyder feilaktig en psykisk lidelse (Lorenzen, 2008). 
dagliglivets funksjoner», ICD-10), som for eksempel motorikk, evne til kommunikasjon (å forstå og gjøre seg forstått), sosiale evner, og regulering av adferd og emosjoner (Lorenzen, 2008). De sammensatte vanskene gjør at personer med utviklingshemming (avhengig av grad) i filosofiske og politiske betraktninger plasseres et sted mellom mennesker og dyr (Carlson, 2010; McMahan, 2009; Simplican, 2015; Singer, 2005). I et samfunn som verdsetter uavhengighet, intelligens og individuelt ansvar, er begrensninger på disse områdene spesielt stigmatiserende og medfører marginalising.

Verdighet har blitt et transformativt begrep for personer med nedsatt funksjonsevne, men for mennesker med utviklingshemming har det ikke hatt den samme frigjørende funksjonen. Gjennom å ta i bruk og eie en forståelse av menneskeverd for seg selv (tenBroek, 1966) har funksjonshemmede oppnådd lovfestede rettigheter. Deres krav om selvbestemmelse og likeverdig deltakelse i samfunnet har bidratt til å endre synet på hva funksjonshemming innebærer. Definisjonen av funksjonshemming er endret fra et fokus på individets begrensninger eller lyter (medisinsk eller tradisjonell definisjon), til vekt på samfunnsskapte barrierer som hemmer likeverdig deltakelse (sosial eller materiell modell) eller som en vekselvirkning mellom disse (relasjonell forståelse). Konvensjonen om rettighetene til personer med nedsatt funksjonsevne (CRPD) skjelner derfor mellom funksjonsnedsettelse og funksjonshemming, der funksjonshemming innebærer de faktorer som hindrer samfunnsdeltakelse. Disse består i den enkeltes funksjonsnedsettelse, holdninger og fysiske barrierer (CRPD, i fortalen, punkt e). Konvensjonen skal bidra til at personer med nedsatt funksjonsevne oppnår «fullgod og effektiv deltakelse og inkludering i samfunnet» (CRPD artikkel 3c). Men selv innenfor funksjonshemmedes rettighetsbevegelser, har inkludering av personer med nedsatt kognitiv funksjonsevne ikke vært uproblematisk. En har tenkt at personer med utviklingshemming er avhengige på en mer grunnleggende måte, og vil svekke andre funksjonshemmedes kamp for selvbestemmelse, medvirkning og likeverdig deltakelse (Drejer, 1994; Goble, 2004, s. 35; Shakespeare, 2014, s. 100101). Personer med nedsatt kognitiv funksjonsevne opplever i større grad enn andre at deres funksjonsnedsettelser, og ikke samfunnets strukturelle hindringer, blir fokus i definisjonen av deres funksjonshemming. 
Tradisjonelle måter å definere menneskeverdet på legger vekt på nettopp de egenskapene som berører utviklingshemmedes funksjonsnedsettelser: kognitive og sosiale evner. Den rådende forståelsen av iboende menneskeverd kan føres tilbake til opplysningstidens humanisme. Rasjonalitet, frihet, selvbestemmelse og selvrespekt, og mennesket som et uavhengig moralsk subjekt, er sentrale elementer i denne forståelsen (se f. eks. Wetz, 2005, s. 14-50). Individets personstatus (personhood) defineres av disse egenskapene. Det er mennesket som en normativ agent som kvalifiserer for menneskerettigheter (Griffin, 2010, s. 92-95). Når ideen om et iboende menneskeverd knyttes til denne forståelsen av individets personstatus, henger det sammen med likeverd, samfunnsordninger og sosial rettferdighet. I denne sammenheng blir den utviklingshemmede, «idioten», en motsetning og et problem i drøftingen av likhet/likeverd, rasjonalitet og evne til politisk deltakelse (Locke, [1689] 2003; Rawls, 1996). Den utviklingshemmedes medisinske diagnose understreker hennes begrensninger nettopp med hensyn til de egenskaper som definerer individets personstatus og menneskeverd.

Sammen med menneskeverd som iboende, er verdighet som sosial status og oppgave en vanlig måte å forstå begrepet på. Selv om verdighet som iboende og verdighet som (evne til) moralsk handling ofte går hånd $\mathrm{i}$ hånd (Wetz, 2005, s. 15), er ikke verdighet som sosial status $\mathrm{i}$ denne forståelsen nødvendigvis medfødt. I stedet kan det forstås som en personlig prestasjon, noe man oppnår gjennom moralsk handling, samfunnsnyttig praksis, eller ideell oppførsel. Slik verdighet er mulig å oppnå gjennom å ta i bruk og forfine de evnene mennesket som art besitter. I antikken var verdighet og ære knyttet til hverandre som noe som ga sosial anseelse og status. Denne var forbundet med et dydig vesen, indre holdninger og sosialt akseptabel oppførsel. Verdighet kunne oppnås ved å kunne regulere egne drifter og begjær, og opptre behersket og sindig. I nyere tid kan denne type verdighet være noe man oppnår gjennom dannelse (Wetz, 2005, s. 50-51). Dannelse innebærer en kultivering av individet (både i det indre og det ytre) innenfor ulike (normative) dimensjoner, blant andre en kunnskapsdimensjon, en moralsk dimensjon og en sosial dimensjon. Også innenfor denne forståelsen av verdighet kan personer med utviklingshemming komme til kort, fordi 
funksjonsnedsettelsen ofte har innvirkning på sosiale evner og evne til regulering av adferd og emosjoner.

Disse rådende forståelsene forbinder menneskeverd med evne til selvbestemmelse og evne til moralsk handling. I disse forståelsene av begrepet anses ikke personer med utviklingshemming (avhengig av grad av utviklingshemming) å inneha fullstendig menneskeverd. Tenkere som holder fast ved den rådende forståelsen av menneskeverd løser dette ved for eksempel å argumentere med samfunnets plikt til solidarisk og omsorgsfull ivaretakelse av personer med utviklingshemming. Det vil si plikt til å behandle mennesker som ikke innehar personstatus med verdighet (Griffin, 2010, s. 84-85; Wood \& O'Neill, 1998). Dette er en annen måte å snakke om verdighet på, enn et iboende menneskeverd. Det siste handler om menneskets vesen, det første handler om moralsk førsel; altså hvordan man bør handle overfor andre mennesker, også de som ikke innehar menneskeverd. (Et tredje begrep, som vi kommer tilbake til nedenfor, er et liv i verdighet, som $\mathrm{f}$. eks. kan handle om sosial rettferdighet).

Tanken om menneskeverd som grunnlag for menneskerettighetene er en moralsk begrunnelse mot objektivering, og mot å bli utsatt for krenkende handlinger (jf. Kants kategoriske imperativ). Tanken om iboende menneskeverd etterspør samtidig hvilke kvaliteter og egenskaper som kjennetegner dette iboende. Benevninger av konkrete menneskelige egenskaper som universelt gyldige vil alltid også være ekskluderende. For å løse dette velger enkelte å knytte menneskeverdet til menneskeheten som art, heller enn til egenskaper menneskelige individer besitter (Kittay, 2005b, s. 100-101; Nussbaum, 2006, s. 179-195). Andre forbinder det med det potensialet som ligger i å være født menneske, uavhengig om det kan virkeliggjøres eller ikke (Waldron, 2017, s. 240-243). I det følgende skal vi drøfte tilnærminger til inkluderende forståelser av menneskeverdet som tar utgangspunkt i menneskelig mangfold og erfaring. Vi har gruppert disse under tilnærminger som tenker menneskelig sårbarhet og avhengighet som noe som gjelder alle mennesker, og i tilnærminger som forstår realisering av rettigheter som vilkår for menneskeverd. 


\section{Sårbarhet, avhengighet og verdighet $\mathrm{i}$ mellommenneskelige relasjoner}

I anerkjennelsen av at idealene som ligger i menneskeverdstanken tradisjonelt ikke beskriver mangfoldet i menneskers erfaring, har enkelte grepet tak i sårbarhet som et allmennmenneskelig (universelt) kjennetegn, og som grunnleggende for menneskeverdet. I stedet for frihet, selvbestemmelse og intellekt, trekkes menneskers gjensidige avhengighet av hverandre fram som det grunnleggende ved menneskelig eksistens (Kittay, 2005b; MacIntyre, 1999; Nussbaum, 2006). Verdighet tenkes her til stede i relasjoner mellom mennesker (Kittay), i menneskelige fellesskap (MacIntyre), eller i et «anstendig samfunn» (Nussbaum).

Feministen og omsorgsetikeren Eva Kittay forkaster selvbestemmelse og autonomi som sentralt for menneskeverdet (Kittay, 2005a, s. 100). Hun mener en slik forståelse av menneskeverd er begrensende fordi verdigheten da avhenger av evnen til å gi uttrykk for egne valg - noe ikke alle mennesker evner. Hun vil allikevel ikke gi slipp på tanken om iboende individuelt likeverd som et viktig element i menneskeverdstanken. I stedet for å knytte dette til konkrete menneskelige egenskaper, understreker hun tilhørighet til arten menneske som begrunnelse for iboende menneskeverd. Likeverd/ egenverd/menneskeverd i hennes forståelse kommer til uttrykk i menneskers omsorgsfulle forhold til hverandre. Hun knytter dermed menneskeverd til omsorgsevne, og definerer det å gi omsorg som en «moralsk kraft utløst som tilsvar til den enkeltes iboende verdighet.» (Kittay, 2005b, s. 113). Gjennom setningen «vi er alle en mors barn» (Kittay, 2009, s. 624-625) appellerer hun til morsomsorgen som et uttrykk for at verdighet og menneskeverd blir til i en omsorgsrelasjon. Gjennom denne relasjonen tildeles, anerkjennes og aktualiseres menneskeverdet, ifølge Kittay. En slik forståelse av verdighet ser det moralske subjekt som relasjonelt, og moralsk dømmekraft knyttes til utvikling av «empati, evne til følelsesmessig respons og perseptuell oppmerksomhet.» (Kittay, 2011, s. 53). Kittays eksempler knytter seg framfor alt til nære relasjoner (familie; mor-barn). Hun hevder at gjensidighet finner sted $i$ alle relasjoner mellom mennesker, og at «personstatus» og verdighet tilskrives i slike relasjoner. Hun mener at en slikt 
omsorgsetikk også har relevans for andre områder, som for eksempel som utgangspunkt for et rettferdig samfunn og alle menneskers velferd.

Det er først og fremst det at et menneske betyr noe for noen som gir personstatus og verdighet i følge Kittay. Derfor kan hun si at verdighet også finner sted i asymmetriske relasjoner. Muligens undervurderer hun i denne sammenheng dynamikken i forholdet mellom hjelper og den som blir hjulpet. I skolesammenheng reiser denne måten å tenke på framfor alt spørsmål om hvordan og på hvilke arenaer evnen til å utvikle slike dype relasjoner skal læres. Er det noe som skjer kun i nære relasjoner mellom mennesker (altså familien eller i samhandling omsorgsgiver og omsorgstaker)? Hvordan kan denne erfaringen overføres til skoleeller samfunnssammenheng? Et videre spørsmål som ikke besvares utviklingshemmedes tilstedeværelse og deltakelse i samfunnet utenfor de nære relasjoner.

Kittay henter inspirasjon blant annet fra Alasdair MacIntyre og Martha Nussbaum i sin forståelse av verdighet. Med henvisning til MacIntyre, viser hun til nødvendigheten av å anerkjenne at alle mennesker er avhengige av andre. Hun viser til Martha Nussbaum når hun argumenterer for viktigheten av å skape gode levekår for personer med nedsatt funksjonsevne.

Alasdair MacIntyre legger ikke vekt på verdighetsbegrepet, men det er allikevel mange likheter mellom hans og Martha Nussbaums tilnærminger til funksjonshemmede, og spesielt personer med nedsatt kognitiv funksjonsevne og deres plass i samfunnet. De forstår funksjonshemming, eller hva funksjonsnedsettelser innebærer for den enkelte, som noe samfunnsavhengig (MacIntyre, 1999, s. 75; Nussbaum, 2006, s. 222). De understreker begge menneskers gjensidige avhengighet og samfunnets forpliktelser overfor personer med ulike grader av funksjonsnedsettelser. De har til felles en aristotelisk grunnforståelse av mennesket som et dyrisk og sosialt vesen (MacIntyre, 1999, s. 6). Som sådan er det preget av kroppslige erfaringer, behov og begrensninger, relasjonelle behov og egenskaper, i tillegg til rasjonelle egenskaper (Nussbaum, 2003, s. 54, 2006, s. 221). De deler også et fokus på fellesskapet som ramme for menneskets (muligheter for) utvikling og realisering av sitt potensiale for praktisk dømmekraft (practical reasoning) (MacIntyre) eller kapasiteter 
(Nussbaum). Det er ifølge Nussbaum her verdighet realiseres. Men mens Nussbaum bruker menneskerettighetene i utviklingen og begrunnelsen av sin «capabilities approach» (Nussbaum, 1997), er MacIntyre skeptisk til menneskerettighetene (MacIntyre, 2007 [1981]s. 66-70).

Alasdair MacIntyre bruker ikke begrepet menneskeverd eller verdighet. I stedet skriver han om «individual and common goods» og menneskelige egenskaper som kreves for menneskelig trivsel både individuelt og i fellesskap - hvor individets trivsel er avhengig av fellesskapets. Han mener at å ta funksjonsnedsettelser på alvor innebærer å innse at det berører alle i noen grad og på ulike tidspunkt i livet (MacIntyre, 1999, s. 73, 130). Lidelse, sårbarhet og avhengighet tas dermed alvorlig som sentrale elementer i menneskelig eksistens. Erkjennelsen av disse er en forutsetning for å utvikle uavhengighet (MacIntyre, 1999, s. 85). Han appellerer til en bevissthet om at «det kunne ha vært meg» i møte med dyp kognitiv funksjonsnedsettelse (MacIntyre, 1999, s. 100-101, 128). Gjennom et nettverk av mellommenneskelige «gi-og-ta»-forhold utvikler den enkelte en praktisk dømmekraft som bare finner sted i fellesskap. Denne kommer også de som ikke har evne til slik dømmekraft til gode, som for eksempel personer med nedsatt kognitiv funksjonsevne. Slik praktisk dømmekraft i fellesskap innebærer en fortolkende kjennskap til egne og andres erfaringer og behov (MacIntyre, 1999, s. 14-18). I et slikt samfunn, mener MacIntyre, nyter den utviklingshemmede respekt og selvrespekt som individ. Han/ hun både tilkjennes omsorg og gir omsorg som bidrar til at alle lærer om hva som er til eget og samfunnets beste (1999, s. 135). Praktisk dømmekraft som ideal for den enkelte for samfunnets beste, innebærer for MacIntyre en utvikling fra avhengighet til uavhengighet, og fra å være mottaker av omsorg og beskyttelse til en som gir omsorg og beskyttelse. Personer med nedsatt kognitiv funksjonsevne vil bare i begrenset grad kunne utvikle en slik praktisk dømmekraft for seg selv, men skal tilkjennes respekt og anerkjennelse, som mennesker «vi» kan lære noe av (1999, s. 135-142). I denne sammenheng kan verdighet forstås som noe som oppstår i mellommenneskelige relasjoner. Verdigheten i denne forståelsen er ikke knyttet til individet basert på menneskelige egenskaper som intellektuelle evner eller sårbarhet. Den er til stede i erkjennelsen av gjensidig avhengighet, og den respekt og generøsitet for den andre som oppstår i den sammenheng. 
MacIntyre er opptatt av hvor og hvordan praktisk dømmekraft læres. Utvikling av verdighet kan forstås som en prosess, knyttet til de dygder som utvikles i bevisstheten om gjensidig avhengighet og utvikling av praktisk dømmekraft i gjensidige relasjoner. Verdighet er altså noe som oppleves og finner sted innenfor rammen av et fellesskap. Sett på denne måten, vil inkluderende opplæring være nødvendig for utvikling av hele samfunnet til felles beste. Den utviklingshemmedes unike erfaring og behov må «høres» i fellesskapet. I opplæringssammenheng må elever oppleve og lære av ulike former for menneskelig eksistens for at menneskelig verdighet skal formidles gjennom og realiseres i gjensidig avhengige relasjoner. Imidlertid ligger det i MacIntyres tilnærming en mulig instrumentell tolkning av mennesker med utviklingshemming. De kan ikke i samme grad som andre utvikle uavhengig praktisk dømmekraft som andre mennesker, til tross for hans tanker om at disse utvikles i fellesskap. Utviklingshemmede tilkjennes en plass, ved at deres erfaringer skal vies oppmerksomhet, men de får en instrumentell funksjon: De skal minne andre mennesker om deres grunnleggende sårbarhet gjennom bevisstheten om at «det kunne ha vært meg.» Deres erfaringer bidrar til andre menneskers utvikling av uavhengig dømmekraft.

Både MacIntyre og Kittay understreker den velfungerendes og samfunnets ansvar overfor den utviklingshemmede. Martha Nussbaum understreker på lignende vis menneskers gjensidige avhengighet. Mennesker er «vulnerable temporal creatures, both capable and needy, disabled in many different ways» og «in need of a rich plurality of life-activities.» (Nussbaum, 2003, s. 54, 2006, s. 221). Verdighet er i hennes forståelse en intuisjon om noe som alle levende vesener besitter (2006, s. 157; 346). En kan si at Nussbaum snakker om verdighet på ulike måter: som iboende, som noe som finner sted der menneskelige behov blir møtt (likeverd), og i betydningen anerkjennelse og respekt. For Nussbaum eksisterer menneskeverdet på lik linje med andre arters verdighet. Men menneskeverdet er artsspesifikt, knyttet til de muligheter og evner mennesker som biologisk art besitter. Menneskeverdet er derfor utgangspunkt for, og nært knyttet til, menneskeartens konkrete behov og kapasiteter (capabilities) ${ }^{2}$. Et liv

2 For en drøfting av gode norske begreper som oversettelse for capabilities se (Lied, 2012, note 6), som bruker begrepet «mulighetsbetingelser». 
i verdighet er dermed et liv der det gis mulighet for at disse behovene blir møtt, og hvor kapasitetene får mulighet til å utvikle seg. Verdighet i betydningen likeverd knyttes til samfunnets evne til å gi alle like muligheter for å utvikle sine kapasiteter. Nussbaum bruker også verdighet i forbindelse med menneskets kapasitet for tilhørighet, anerkjennelse og selvrespekt - her bruker hun verdighet som motsetning til krenkelse og ydmykelse (Lied, 2012; Nussbaum, 2006, s. 77, 172).

Nussbaum avviser ikke rasjonalitet som en del av egenskapene som knyttes til menneskeverdet. Men hun knytter verdigheten i større grad til sosiale egenskaper som realiseres blant annet gjennom og i mellommenneskelige relasjoner. Også behov for omsorg utgjør en del av menneskelig verdighet. Hun mener som Kittay at selv relasjoner preget av en stor grad av asymmetri også er preget av gjensidighet (Nussbaum, 2006, s. 160). Verdighet eller menneskeverd i denne forståelsen er ifølge Nussbaums formulering verdigheten til kroppslige, trengende vesener (needy enmattered beings) (2006, s. 278). Menneskeverdet/verdighet er forbundet med hvilke kapasiteter som må møtes/gis rom til en viss grad, for at det skal være mennesket verdig (2006, s. 181). Disse kapasitetene inkluderer liv; helse; kroppslig integritet; sanser, forestillingsevne og tenkning; emosjoner; praktisk dømmekraft; tilhørighet; forhold til andre arter; lek; og kontroll over eget miljø. Nussbaums anliggende er først og fremst politisk. Et rettferdig samfunn må etter hennes forståelse utvikles med tanke på menneskers ulike behov og endrede forutsetninger gjennom et livsløp. Derfor må forståelser av hva verdighet er utvikles i respekt for menneskelig mangfold (Nussbaum, 2008), og kapasitetsbeskrivelsene ta utgangspunkt i hva som skal til for at vesener med menneskelig artstilhørighet skal trives (flourish). For personer med kognitive funksjonsnedsettelser betyr det at intuisjonen om iboende menneskeverd må knyttes til arten menneske, ikke til enkelte (foretrukne) menneskelige egenskaper. Videre betyr det at samfunnets ansvar for å skape sosiale forutsetninger for utviklingen av menneskelige kapasiteter gjelder overfor alle borgere, uavhengig om de evner å gjøre seg nytte av dem (2006, s. 191-195). Ettersom alle mennesker i løpet av livet vil ha behov for å bli tatt vare på, må et anstendig samfunn i Nussbaums forståelse sørge for et omsorgssystem som tar utgangspunkt i de sentrale menneskelige kapasitetene, som mulighet, og uten tvang. 
Disse tre tilnærmingene holder fast ved en forstålse av verdighet som er ment å inkludere variasjonen av menneskelig erfaring. Sårbarhet og gjensidig avhengighet er sentralt. De legger vekt på elementer som omsorg, det å lære av hverandre og anerkjennelse av individuelle begrensninger. Dette er viktige påminnelser og gode utgangspunkt for etisk praksis i skolesammenheng og i samfunnet for øvrig. I fokuset på omsorg, omsorgsbehov og gjensidig avhengighet, undervurderer disse den utviklingshemmedes utsatthet $\mathrm{i}$ asymmetriske relasjoner, og det maktforhold som oppstår i forholdet mellom hjelpetrengende og hjelper. Erkjennelsen av at alle mennesker trenger omsorg i løpet av livet er en nyttig påminnelse om livets skjørhet og menneskers gjensidige avhengighet av hverandre. Det er allikevel en vesensforskjell i tilfeller der en part alltid vil være i behov for hjelp. Noen vil alltid ha behov for omsorg. I slike tilfeller er ikke forholdet mellom omsorgstaker og omsorgsgiver nøytralt eller gjensidig. Avhengigheten gjør den enkelte potensielt utsatt for velmenende eller utilbørlige overgrep. Ofte ligger det i omsorgsgiverens makt å definere behov og hva som er best for den enkelte omsorgsmottaker. Tanken om gjensidig avhengighet og omsorg vektlegger den utviklingshemmede som likeverdig subjekt. Men hans/hennes sårbarhet og avhengighet av omsorg og veldedighet er mer konstant enn for de fleste. Da forblir den utviklingshemmede, med sine begrensninger, objekt. Hans eller hennes verdighet er avhengig av omsorgspersonen (jf. Kittay), eller den utviklingshemmede blir instrumentell i utviklingen av andres verdiget, som «en vi kan lære om oss selv» av (jf. MacIntyre).

\section{Singularitet og realisering av rettigheter som vilkår for verdighet}

Behov for omsorg og velferdstjenester skaper avhengighetsforhold, og i mange tilfeller marginalisering, diskriminering og ulikhet. En person som beskjeftiger seg med forholdet mellom verdighet og nedverdigelse eller krenkelse er Avishai Margalit (Margalit, 1996). Han kombinerer en politisk og en moralsk tilnærming, og i likhet med MacIntyre og Nussbaum er han opptatt av hva som skaper et anstendig samfunn. Margalit 
skjelner mellom et anstendig samfunn, som et som ikke nedverdiger personer (Margalit, 1996, s. 10-11; 41), og et sivilisert samfunn, hvis medlemmer ikke nedverdiger hverandre. Margalit betoner også forholdet mellom verdighet og rettigheter annerledes enn mange, og framholder at menneskerettighetene ikke baseres i tanken om menneskeverd, men snarere rettferdiggjøres ved at de ivaretar menneskers verdighet. Med referanse til Erving Goffmans Stigma (Goffman, 1963), drøfter han mekanismer som marginaliserer og gjør mennesker til undermennesker. For eksempel kan dette skje ved at en bestemt egenskap som oppfattes som avvikende blir bestemmende og forvrenger vårt bilde av den andre som menneske (Margalit, 1996, s. 104). A behandle mennesker som barn, eller som om de aldri kommer til å bli voksne, er en måte å nedverdige mennesker på. Som eksempel gir han hvordan personer med Downs syndrom ofte oppfattes og behandles. Å utelukke mennesker fra "den menneskelige familie», er også en ydmykelse. I likhet med bl.a. Iris Young peker Margalit på hvordan både veldedighet og velferdsordninger potensielt kan bidra til marginalisering (Young, 1990). De kan generere holdninger som «å synes synd på» (pity), eller de utsetter mennesker for systemer som begrenser den enkeltes kontroll og myndighet. Margalit knytter menneskeverdet til respekt for mennesker, tilhørighet og selvrespekt.

Margalit er ikke først og fremst opptatt av funksjonsnedsettelser. Han tar opp problemstillinger som knyttes til marginalisering av mennesker hvis egenskaper faller utenfor det som ofte oppfattes som «normale». Dette er en annen måte å tilnærme seg menneskelig mangfold på enn f.eks. Nussbaum og MacIntyre gjør. Gjennom å allmenngjøre «svakhet» og «avhengighet» appellerer MacIntyre til empati og gjenkjennelse for å argumentere for funksjonshemmedes plass i samfunnet. Både MacIntyre og Nussbaum understreker behovet for en verdighetsforståelse som tar utgangpunkt i variasjoner i menneskelige erfaringer. Margalit antyder i stedet behovet for å bli respektert som menneske med de egenskapene den enkelte besitter, uten å begrunne dette i andre allmennmenneskelige trekk enn tilhørighet til den menneskelige familie.

En annen, som i likhet med Margalit er opptatt av singularitet eller særegenhet og det unike ved den enkeltes eksistens, er Julia Kristeva. 
Som Nussbaum, Kittay og MacIntyre trekker hun fram menneskelig sårbarhet, og vil legge begrepet til opplysningstidens humanisme: «Frihet, likhet, brorskap og sårbarhet.» (Kristeva, 2008, 2010). Samtidig stiller hun seg kritisk til måter å forstå mennesket på som påberoper seg å være allmenngyldige, fordi det avdekker «avvik» - mangler hos den enkelte som leder til paternalisme eller veldedighet. Hun plasserer opprinnelsen til denne tenkemåten nettopp i Aristoteles' begrep om menneskets kapasiteter, som har en universell menneskeform som forutsetning. Avviket representerer en brist eller frarøvelse (steresis) som samfunnet forsøker å bøte på eller komplettere gjennom en idé om integrering. Det funksjonshemmede subjekt blir et omsorgsobjekt som skal tas vare på og infantiliseres (Kristeva, 2013, s. 227). I stedet ønsker Kristeva å fokusere på de mulighetene og kreftene som ligger i personens unike «vesen». Funksjonsnedsettelsen er en integrert del av dette singulære, betingede livet. Det er en måte å være menneske på. I stedet for integrering, ønsker hun genuin interaksjon. Som Kittay appellerer hun til morskjærligheten, og vil bytte ut «solidaritet med de svake» med kjærlighet til singulariteter - særegne måter å være i livet på. Når Kristeva appellerer til opplysningstidens humanisme framhever hun også rettighetene til personer med funksjonsnedsettelser som medborgere, som politiske subjekter, som er «like i verdighet og rettigheter» (Kristeva, 2010). Verdigheten til personer med nedsatt funksjonsevne er til stede når deres rettigheter er ivaretatt, og når deres unike sårbarhet anerkjennes. Denne unike sårbarheten, eller annerledesheten, mener hun er strukturell, og skyldes frykten og usikkerheten funksjonsnedsettelsen skaper hos andre mennesker. Hun mener funksjonsnedsettelser i dagens samfunn blir representant for det tragiske; stedet mennesker blir konfrontert med lidelsen og de destruktive krefter som er i alle mennesker, men som vi ikke ønsker eller orker å konfronteres med.

Kristeva er blitt kritisert for å framheve den funksjonshemmedes unike annerledeshet, fordi det kan synes å forsterke den fremmedgjøring som hun ønsker å få bukt med (Grue, 2013). I sammenheng med spørsmål om utviklingshemming og verdighet, ønsker vi imidlertid her først og fremst å framheve hennes fokus på det singulære/unike ved menneskers eksistens og erfaring, og hvordan det bidrar til både å forstå 
menneskelig eksistens, og til å forskyve og redefinere grensene for det «normale». Hun ønsker å framheve livet som en tilblivelsesprosess, og de unike positive kapasitetene som det enkelte menneske besitter. Selv om Kristevas betoning av det unike i utviklingshemmedes erfaring også kan forstås ekskluderende, tør hun benevne noe avgjørende med hensyn til utviklingshemmedes situasjon: deres sårbarhet er vedvarende, konstant, og strukturell. Deres begrensninger berører evner som oppfattes som grunnleggende ved det å være menneske: intellekt, språk, regulering av følelser, samt sosiale ferdigheter.

I det foregående har vi sett på ulike tilnærminger til verdighet som tar utgangspunkt i menneskelig mangfold. Disse ser utfordringer ved verdighetsforståelser som ekskluderer mennesker med nedsatt funksjonsevne. Flere av tilnærmingene tar utgangspunkt i sårbarhet og menneskelige begrensninger som noe som gjelder alle mennesker, og verdighet som noe som skjer i relasjonen mennesker i mellom. Verdighet i disse tilnærmingene er noe som oppnås/tilskrives/finner sted i menneskelige fellesskap, der den enkelte blir anerkjent eller verdsatt. Dette skjer enten gjennom at den enkelte betyr noe for et annet menneske (og dermed får personstatus), eller at fellesskapet gir muligheten for å utvikle egne evner og kapasiteter. Krenkelser, marginalisering og utelukkelse fra fellesskapet beskrives som tap av verdighet.

I det følgende vender vi blikket mot skolen og lærere som arbeider med barn med utviklingshemming. Vi ønsket å forstå hvordan eller hvorvidt verdighet som en del av skolens verdigrunnlag påvirker pedagogisk praksis.

\section{Verdighet i læreres praksis med utviklingshemmede barn}

Som beskrevet innledningsvis i artikkelen ønsket vi å utforske verdighetsbegrepet i sammenheng med nedsatt kognitiv funksjonsevne og inkluderende opplæring. Bakgrunnen for dette var en bevissthet om at personer med nedsatt kognitiv funksjonsevne spesielt, til tross for inkluderende språk og intensjoner allikevel opplever marginalisering, både i diskurser om menneskeverd og i skolen. Opplæring av barn med nedsatt 
kognitiv funksjonsevne er altså sammenhengen vi ønsket å undersøke verdighetsbegrepet innenfor. Vår antakelse eller forforståelse var at forståelser av verdighet også kommer til uttrykk i pedagogisk praksis. Vi inviterte derfor fem lærere til samtaler om skole, utviklingshemming og verdighet.

I utforming av intervjuguiden som ga grunnlaget for samtalene tok vi utgangspunkt i skolens formålsparagraf samt skolens plikt til å ivareta elevenes læringsmiljø og å «gripe inn mot krenkelser» og diskriminering. Vi stilte derfor spørsmål om hvordan lærerne vil beskrive et godt læringsmiljø og hvordan lærerne arbeidet for å ivareta et godt læringsmiljø for alle elever. Rett til å gå på nærskolen og rett til tilpasset opplæring har vært et grunnleggende prinsipp i norsk skole gjennom årtier (Johnsen, 2010, s. 132-138). Norges tilslutning til Salamancaerklæringen i 1994 og CRPD legger også føringer om inkluderende opplæring. Fordi CRPD setter inkludering og menneskeverd i sammenheng med hverandre, ble det også naturlig for oss å stille spørsmål om inkluderende opplæring i samtalene med lærerne. Vi samtalte om inkluderende og segregerende tiltak, og begrunnelsene for disse, og vi spurte konkret om lærernes forståelse av verdighet. Lærerne ble gitt stor frihet til å komme med eksempler og forklaringer. De kom selv inn på forhold mellom elever med utviklingshemming og andre elever.

Analysen av samtalene ga utgangspunkt for drøftinger forfatterne imellom, med tanke på hva verdighet betyr og hvordan lærernes ivaretakelse av elevenes verdighet resulterte i forskjellige tiltak. Analysen var informert av CRPDs formuleringer i artikkel 24 om formålet med opplæring med tanke på målsettinger om likeverdig deltakelse, og utvikling av barnets fulle potensiale, selv-følelse og følelse av verdighet. Vi så etter situasjonsbeskrivelser der disse ble eksemplifisert eller motsagt. Vi så også etter formuleringer som ga uttrykk for hvordan lærerne omtaler barn med utviklingshemming i motsetning til andre barn, - om vekten ble lagt på barnas begrensninger eller om de lå på barnas potensiale for utvikling. Videre så vi på hvordan lærerne omtaler barnas ulike behov og ferdigheter. I begrunnelsene for segregering eller integrering så vi etter formuleringer som ga uttrykk for muligheter for deltakelse i fellesskapet, og hva som i lærernes øyne kvalifiserer for eller hindrer slik deltakelse. I 
analysen og drøftingen av lærernes beskrivelser av praksis, kom det fram flere og andre eksempler på hvordan verdighet realiseres eller krenkes i praksis, enn de vi selv hadde drøftet på forhånd. Dette viser at selv om lærerne i liten grad brukte verdighet som begrep, gir skolens praksis og elevenes samhandling mange muligheter for å drøfte verdighet og hva det kan bety i forholdet mellom elever og mellom lærer og elev.

Vi var interessert i verdighet i forhold til inkluderende og segregerende pedagogiske praksiser. Et lite forbehold om begrepsbruk er derfor på sin plass. CRPD (UN, 2016, punkt 11, s. 4) skjelner mellom ekskludering, segregering, integrering og inkludering i opplæringen. Segregering innebærer en plassering av personer med funksjonsnedsettelser «i separate miljøer ... i isolasjon fra elever uten funksjonsnedsettelser.» Integrering beskrives som «en prosess der personer med funksjonshemminger blir plassert i eksisterende generelle utdanningsinstitusjoner» så lenge elevene kan tilpasses seg disse. Inkludering handler ifølge CRPD om systemisk reform som blant annet berører fysiske, metodiske, strukturelle endringer som skal bidra til å bygge ned barrierer som hindrer rettferdig og deltakende læring og læringsmiljø. CRPD presiserer at «å plassere elever med funksjons-nedsettelser i ordinære klasserom uten ledsagende strukturelle endringer» ikke kan defineres som inkludering. I lys av CRPD er det ikke klart hvorvidt semi-segregerte systemer som baser eller forsterkede enheter er å regne som inkluderende praksis. I vår forståelse beskriver kun en av lærerne noe som er tilnærmet lik inkluderende opplæring, og denne anser dette mulig bare opp til en viss alder. De andre beskriver situasjoner beskrevet av CRPD som integrerende praksis. Vårt fokus har ikke vært på hva som utgjør «inkluderende opplæring» som sådan, men på verdighetsforståelser slik de kommer til uttrykk i lærernes pedagogiske praksis. Lærerne selv skjelnet ikke mellom integrering og inkludering i sin praksis: begrepene ble brukt om hverandre i betydningen: å plassere elever med utviklingshemming i ordinære klasserom. Vi har beholdt begrepet inkludering der lærerne beskriver ønske eller forsøk på å inkludere utviklingshemmede elever i et sosialt fellesskap.

Det syntes vanskelig for lærerne å snakke om sin egen forståelse av verdighet. De brukte begrepet i liten grad, og satte selv ikke begrepene menneskeverd eller verdighet i sammenheng med drøftingen av integrering 
eller inkluderende opplæring. Da vi spurte direkte hva begrepet innebærer for dem, ble de usikre og vage og støttet seg på standardformuleringer som «alle mennesker er like mye verdt», uten å knytte det til egen praksis. Allikevel fant vi gjennom analysen av lærernes refleksjoner over sine egne pedagogisk praksiser og deres begrunnelser for disse, å kunne skjelne mellom fire forskjellige måter lærerne ga uttrykk for verdighet på: iboende menneskeverd; likeverd; verdighet som sosial anseelse/status og verdighet som tilhørighet. Andre elementer, som ofte forbindes med et liv i verdighet, kom i samtalene ikke like tydelig til uttrykk. Framfor alt synes lærerne å legge vekt på relasjoner og sosial samhandling i større grad enn for eksempel autonomi, retten til å treffe egne valg, egenverd og selvrespekt.

\section{Iboende verdighet/likeverd}

Selv om lærernes usikkerhet når det gjaldt begrepet verdighet var påfallende, fant vi en grunnleggende innstilling til elevene i lærernes refleksjoner omkring egen praksis som kan defineres som basert i en verdighetstenkning. Med Nussbaum kan man kanskje si at det handler om en intuisjon om verdighet som er bestemmende i lærernes holdning overfor og i møte med den enkelte elev. Den første umiddelbare assosiasjonen lærerne hadde til begrepet, var «iboende verdighet». Lærerne gjenga en slags programmatisk forståelse av verdighet: at alle i kraft av å være mennesker har verdi, og at menneskeverd ikke er avhengig av ytelse eller forutsetninger. Når bedt om å utdype formulerte en lærer det slik: «Det er helt greit at noen trenger ekstra hjelp». En annen slik: «Du er kommet til denne verden, og har noe å gi uansett hvilke forutsetninger du har.» Svarene kan muligens reflektere en slags forståelse av verdighet knyttet til «arten» menneske, i likhet med det Kittay eller Nussbaum viser til. Imidlertid var det ikke tydelig at lærerne selv satte verdighetsbegrepet eller menneskeverdet i direkte sammenheng med sin pedagogiske praksis. Først og fremst synes menneskeverd for lærerne å handle om måten lærerne omgås elevene på. De legger vekt på at elever med utviklingshemming har krav på å bli møtt med respekt, og å bli tatt alvorlig. Respekt i denne sammenheng, slik lærerne uttrykker seg, handler om holdningen man viser enkeltindividet som 
medmenneske, altså i moralsk forstand om lærerens plikt i relasjonen mellom lærer og elev.

Forforståelsen som kommer til uttrykk i alle samtalene er imidlertid ikke likhet, men heller at elevene med utviklingshemming representerer annerledeshet og avvik. Allikevel ser et par av lærerne menneskeverd og likeverd i sammenheng med hverandre. En lærer understreker viktigheten av inkludering for den utviklingshemmedes opplevelse av likeverdighet. Utgangspunktet her er den utviklingshemmedes sårbarhet. Når læreren understreker inkluderende læringsaktiviteter der den utviklingshemmede får oppleve «at andre også strever», synes hun å antyde at møtet med andres sårbarhet gir gjenkjennelse og dermed også bidrar til den utviklingshemmede elevens utvikling av selvrespekt og opplevd likeverd. Dette er en annen type gjenkjennelse enn den f. eks. MacIntyre snakker om. MacIntyres perspektiv er solidaritet med den som er annerledes. Lærerens perspektiv er den utviklingshemmedes annerledeshet, og hennes anliggende er å skape en mulighet for den utviklingshemmede å finne egenverdi i identifikasjon med gjennomsnittselevene. Men denne læreren framhever også gjensidighet i forholdet mellom elever med nedsatt kognitiv funksjonsevne og deres medelever, der likeverd i likhet med MacIntyres formuleringer kommer til uttrykk i at «medelever har også noe å lære av dem» (dvs. de utviklingshemmede). Læreren beskriver en bevisst praksis der det vektlegges å drive opplysningsarbeid overfor kontaktlærere og foreldre, for å motvirke fordommer og fremme forståelsen av likeverd. Dette skjer gjennom informasjon om diagnose, følger av diagnose, og på hvilke måter integrering gavner alle elevene. Denne læreren beskriver også ansatser til inkluderende praksis (i motsetning til integrerende) gjennom tilpasset opplæring i klasserommet. Læreren ser her verdighet på to måter, gjennom at gjennomsnittseleven lærer å forholde seg til annerledeshet, mens den utviklingshemmede kan oppnå glimt av likeverd. I denne lærerens praksis kommer en sammenheng mellom likeverd og menneskeverd til uttrykk som noe mennesker deler på tvers av ulikheter. Samtidig understreker læreren at inkluderende praksis i stor grad er til nytte for «den svake» eleven, som gjennom samhandling lærer sosialt samspill, og støttes i sin læring av medelevene, der sistnevnte får rollen som supportere og støttepersoner: «Medelever gleder seg over at 
han klarte det, og at de klapper for ham, da føler han seg veldig stolt. De støtter. Medelever føler glede over PU-elevers mestring. Viktig at den svake eleven føler seg støttet av sine medelever.»

Læreren gir her uttrykk for en forståelse av menneskelig sårbarhet som et likhetsprinsipp, og viser slektskap til MacIntyres og Nussbaums forståelse: at mennesker aldri egentlig er uavhengige. I sitt engasjement for inkluderende opplæring praksis, bruker læreren seg selv og sin egen sårbarhet for å forklare for medelever, lærere og foreldre den utviklingshemmedes situasjon, for å skape empati og interesse for den andre. Lærerens forståelse av likeverd får to uttrykk: inkludering, oppmuntring og støtte for den utviklingshemmede på den ene side, og bevisstgjøring og læring for de andre elevene på den andre siden. Forholdet mellom eleven med nedsatt kognitiv funksjonsevne og medelevene er asymmetrisk: det er den svake eleven som får oppmuntring, mens det er gjennomsnittselevene som gir støtte. Nussbaum og Kittay vil her innvende at det finnes gjensidighet også i asymmetriske relasjoner. En kan si at verdighet og opplevelsen av verdighet oppnås i sammenheng med anerkjennelse og oppmuntring fra medelever, slik det er for alle i klasserommet. Eleven med utviklingshemming får en instrumentell rolle i å minne om alle menneskers sårbarhet og avhengighet. Elevens situasjon vekker dermed sympati og kanskje omsorg. Dette kommer spesielt til uttrykk når den samme læreren mener at mens inkluderende praksis er viktig og nyttig på barnetrinnet, kan det vanskelig forsvares på mellom- og ungdomstrinnet: «Når det er enda større krav som stilles, da kan det blir vanskelig å være integrert, det mener jeg».

\section{Verdighet knyttet til ferdigheter, sosial anseelse og status}

Annerledeshet er et tema som går igjen i samtalene med lærerne. Elevenes manglende evner anses å skape en avstand mellom elevene med utviklingshemming og deres medelever. En kan knytte lærernes beskrivelser og begrunnelser for segregerende praksis konkret til verdighet i tradisjonell forstand som det å forstå og tilpasse seg sosiale normer, og evne til å beherske egne impulser. Dette kom til uttrykk på forskjellige måter i samtalene. «Jeg tenker at de andre elevene ser at de er annerledes», 
sier en lærer, og viser til at elever med utviklingshemming mangler sosial kompetanse som gjør at de kan finne seg vel til rette i integrerte klasser. Lærerne beskriver det utfordrende for elevene at de «sliter med sosial omgang». Selv om de snakker om tilrettelegging i klasserommet med tanke på tilpasset opplæring og læringsmiljø som en konkret og selvfølgelig del av sitt virke, kommer det fram at selv med tilrettelegging og hjelpemidler er det noe grunnleggende hos eleven med nedsatt kognitiv funksjonsevne som skaper en permanent barriere i møte med de andre elevene.

Lærernes formuleringer reflekterer en rådende diskurs (jf. Foucault) i skolens universaliserende praksis som er «preget av et sett med forventinger som i utgangspunktet rettes mot alle elever» (Fylling, 2008, s. 99). Elever som ikke når opp til disse forventingene faller utenfor, betegnes som spesielle, eller ses på som avvikende. Formuleringene kan også knyttes til lærernes praksis som spesialpedagoger, hvor målet er en «normalisering» av ulikheter basert på diagnoser definert på bakgrunn av avvik fra det normale (Reindal, 2010, s. 121-122). Lærernes formuleringer knyttet til dikotomien normalitet/avvik gjenspeiler det dominerende syn på elever med nedsatt kognitiv funksjonsevne; et syn som påvirker lærernes pedagogiske praksis og som implisitt gir uttrykk for ulike forståelser av verdighet.

Sett i lys skolens og spesialpedagogikkens normaliserende praksis, kan man si at alle elevers verdighet er knyttet til deres sosiale ferdigheter. Verdighet kommer til uttrykk i sosial anseelse og status. Når lærerne beskriver forskjellene mellom elever med utviklingshemming og andre elever, ligger vekten ikke så mye på deres kognitive funksjonsnivå. Det er i større grad deres manglende kompetanse generelt, og spesielt deres sosiale ferdigheter eller «lekekompetanse», som vektlegges. Lærerne skjelner mellom «godt fungerende» elever, som kan integreres, og svake elever, som vanskeligere kan finne en plass i fellesskapet. I et normaliserings- og likeverdsperspektiv, legger lærerne i opplæringen i stor grad vekt på utvikling av sosiale ferdigheter (f. eks. i motsetning til et fokus på faglig læring). En av lærerne uttrykker det slik: «det faglige utbyttet kan ikke stå i høysetet». Inkluderende opplæring skal, ifølge informantene, tjene eleven med kognitiv funksjonsnedsettelse slik at 
han eller hun mestrer sosiale koder. Vi forstår det slik at lærerne mener det er gjennom å mestre disse kodene at elevene oppnår eller erfarer verdighet. Påfallende og avvikende oppførsel eller interesser, medfører tap av verdighet. Jo mer påfallende oppførsel, jo større er tapet av verdighet. En av lærerne sier: «Elevene med psykisk utviklingshemming slet med å bli anerkjent [blant medelever] som fulle, hele, mennesker.» En annen lærer sier at [for å oppnå anerkjennelse] må «elevene med psykisk utviklingshemming ha noe å tilby som andre elever synes er interessant.» En tredje at: «De må ha en greie som gjør at de blir godtatt.» Det vil si at eleven med nedsatt kognitiv funksjonsevne oppleves i elevgruppa både å mangle kompetanse som gir verdighet, og ikke evne å tilføre fellesskapet noe. Dermed kan eleven verken anses som likeverdig, eller inneha en likeverdig funksjon i fellesskapet. Flere av lærerne gir uttrykk for at andre lærere og foreldre til medelever også finner det vanskelig å anerkjenne elever med utviklingshemming som en del av klassen og klassemiljøet. Vekten ligger på å hjelpe den utviklingshemmede eleven til å opptre og samhandle «normalt».

Innenfor en forståelseshorisont av skolens og spesialpedagogikkens skille mellom «normalitet og avvik» (Fylling, 2008, s. 99) antyder lærerne at segregering av elever med nedsatt kognitiv funksjonsevne fra elever som forventes å følge normert læringsprogresjon er den beste løsningen fra og med mellomtrinnet. Unntak vil være prosjektarbeid eller andre typer undervisning, for eksempel i praktiske fag, som kan tilpasses og bringe fram enkeltelevers særskilte ferdigheter. I slike tilfeller understreker lærerne nytten av å inkludere elever med kognitive funksjonsnedsettelser sammen med andre elever. De vil da kunne oppleve eller oppnå verdighet ved å finne anerkjennelse for sine spesielt gode (for eksempel musikalske eller sportslige) evner, eller ved at medelevene «heiet dem frem» da de oppnådde konkrete læringsmål. Det er mulig å lese en slags likeverdsforståelse fra lærerens side i det første tilfellet: Alle elever har svakheter og styrker, og ved å bringe fram enkeltelevers sterke sider bidrar dette til en opplevelse av anerkjennelse som styrker både deres anseelse og selvfølelse. Allikevel gir begge eksemplene uttrykk for en forståelse av asymmetriske forhold mellom elever med kognitiv funksjonsnedsettelse og deres medelever, der verdighet oppnås 
gjennom positiv vurdering fra medelevene (flertallet). En lærer knytter verdighet konkret til status i denne sammenheng, og påpeker at selv om læreren legger vekt på likeverd, utvikler elevene selv et statushierarki. Ofte fører dette til at elevene med nedsatt kognitiv funksjonsevne vurderer sin egenstatus som lav, og dermed opplever tap av verdighet. Lærerne beskriver her marginaliseringsprosesser lik de Margalit tar opp i samfunnssammenheng.

Asymmetri i forholdet mellom elever med kognitiv funksjonsnedsettelse og medelever kommer også til uttrykk i tiltak som gir medelever ansvar for integreringen. Det kan være tiltak der medelever hjelper elever med kognitive funksjonsnedsettelser faglig, vennegrupper, eller «dagens venn» der enkeltelever etter tur får ansvar for å hjelpe og inkludere eleven med utviklingshemming gjennom skoledagen. Noen av lærerne vurderer disse tiltakene positivt. Når det gjelder vennegrupper understreker en lærer en likeverdstanke som motivasjon for tiltaket. En annen vurderer tiltak som «dagens venn» som krenkende. Læreren mener det oppleves uverdig at medelever skal «passe på» eller tvinges til å være sammen med eleven med utviklingshemming. Dette resonnerer med Kristevas forståelse av hvordan mennesker med nedsatt funksjonsevne infantiliseres og sosialiseres til å bli omsorgsobjekter. Eleven med utviklingshemming opplever å bli sett, opplever en form for vennskap og får en opplevelse å være en del av fellesskapet. Samtidig understøtter denne praksisen elevens identitet som annerledes, som hjelpetrengende, som mottaker av omsorg, både i egen bevissthet og blant gjennomsnittselevene. Slik svekkes elevens anseelse blant medelevene, som en som er hjelpetrengende og annerledes. I tillegg er dette tiltak som i stor grad vurderes av lærerne som enten til gavn eller ulempe for gjennomsnittselevene, det vil si at gjennomsnittselevenes verdighet styrkes eller trues av omgangen med elever med kognitive funksjonsnedsettelser. For eksempel oppnår elever anerkjennelse, respekt og selvrespekt gjennom å fungere som hjelpere, ifølge en lærer. På den annen side, ifølge en annen lærer, risikerer de krenkelser fra eleven de er satt til å hjelpe (som læreren mener i større grad har vansker med å forstå og respektere sosiale regler); de blir påført et ansvar de ikke er rede til å takle, eller de frarøves muligheten til egenutvikling gjennom lek og samhandling med likestilte elever. 
Lærerne er enige om at integrerende tiltak er vanskeligere jo eldre elevene blir, og at «avstanden» mellom elever med utviklingshemming og medelevene blir større. På bakgrunn av lærernes refleksjoner ser vi at segregering kan knyttes til verdighet på to måter: på den ene side beskytter det gjennomsnittselevenes verdighet, på den annen side unngår elevene med nedsatt kognitiv funksjonsevne å miste anseelse eller verdighet i de andres øyne eller å krenkes gjennom nedlatende oppførsel. Lærerne forklarer at elever med nedsatt kognitiv funksjonsevne ofte kompenserer for sin manglende kompetanse eller sosiale ferdigheter gjennom aggressiv eller fjollete adferd, eller de berører medelever fysisk. En kan si at de opptrer uverdig. Inkludering kan føre til at de står i veien for medelevers læring, og de kan ha vanskeligere enn andre elever med å vise respekt og «oppføre seg ordentlig». Segregering bidrar også til at gjennomsnittselevene beskyttes mot påfallende og «rar» adferd. I disse begrunnelsene for segregering er det gjennomsnittselevenes verdighet og beskyttelse av denne som står i fokus. Men segregering oppleves også til gavn for elevene med utviklingshemming gjennom at de beskyttes mot utestenging, latterliggjøring, krenkende kommentarer, osv. I denne sammenheng kan segregering sies å bidra til å bevare elevenes verdighet. Segregering har en konkret funksjon ved at den bidrar til å anerkjenne den enkelte elevs (manglende) evner, og dermed samtidig å beskytte elevene med nedsatt funksjonsevne mot tap av verdighet. Elevenes verdighet må beskyttes ved at de slipper å framstå i fellesskapet som «ekle», «rare», forstyrrende osv.

\section{Verdighet i sammenheng med tilhørighet, mestring og selvrespekt}

Alle lærerne vektlegger tilhørighet i forbindelse med spørsmål om inkluderende opplæring eller segregerte klasser. Tilhørighet er også en av de sentrale kapasitetene i Nussbaums liste, som hun selv antyder sentral (Nussbaum, 2006, s. 77, 292) Hun mener et fravær av like muligheter for sosial tilhørighet vil innebære mangel på verdighet og selvrespekt. Hun knyttet dette til ikke-diskriminering som prinsipp. I lærernes refleksjoner framlegges tilhørighet som begrunnelse både for integrering og for segregering. Lærerne observerer at integrering ofte fører til sosial 
isolasjon og ensomhet. Eleven med nedsatt kognitiv funksjonsevne «faller utenfor». Derfor mener en av lærerne at elever med nedsatt kognitiv funksjonsevne må ha en gruppe likesinnede å forholde seg til, som en base som gir tilhørighet og mestring, og være rotfestet i denne når de «går ut og møter de andre» i praktiske fag. Læreren mener at hvorvidt elevene opplever anerkjennelse og tilhørighet sammen med gjennomsnittselever er avhengig av den enkelte elevs funksjonsnivå, og hvorvidt de kan knyttes opp mot de toneangivende medelevene. Alle lærerne mener at elever med kognitiv funksjonsnedsettelse i mange tilfeller selv vil oppleve at de er annerledes, mangler status eller ekskluderes. Dette påvirker både deres følelse av tilhørighet, deres følelse av mestring og dermed også deres selvrespekt. Lærerne legger vekt på at elevene må få oppleve frihet til å være seg selv og forfølge egne interesser. De opplever dette viktig både for læringsmiljøet og for elevenes mestringsfølelse og selvtillit. En av lærerne understreker at kontakt med andre blir et økende behov i ungdomsalder, da individet formes i stor grad. Lærerne ser altså en sammenheng mellom tilhørighet, mestring og selvrespekt. Det kan tolkes dit hen at elevene opplever verdighet gjennom sosial kontakt, identifikasjon og tilhørighet til en gruppe, og gjennom å oppleve frihet til å utfolde seg uten nødvendigvis å måtte forholde seg til sosiale koder det er vanskelig å mestre. Segregering fungerer altså i mange tilfeller som et tiltak som ivaretar elevenes kapasitet for tilhørighet og selvrespekt tilsvarende Nussbaums tilnærming, og bidrar til å bevare elevenes verdighet.

En av lærerne gir i denne sammenheng også et eksempel på vellykket integrering: Elever med nedsatt kognitiv funksjonsevne fikk opplæring sammen med elever som hadde norsk som fremmedspråk. Disse elevene var samtidig vel ansett i klassen som helhet. Deres ivaretakelse av elevene med utviklingshemming ble et mønster for de øvrige elevene. Læreren forklarer at dette muligens var vellykket fordi de andre elevene (de som hadde norsk som fremmedspråk) «også hadde en svakhet».

At lærerne begrunner segregering med identifikasjon, tilhørighet og manglende sosial kompetanse er interessant. Det kan synes som tilhørighet og mestring som grunnlag for de utviklingshemmedes verdighet dermed er å finne i deres felles identitet som utenforstående det større elevfellesskapet. Det kan synes som om elever med nedsatt kognitiv 
funksjonsevne finner en befrielse i dette utenforskapet: at man i et felles utenforskap finner en frihet til selvutvikling og mulighet for identifikasjon på tvers av evner, som de ikke finner innenfor «normalen». Vi forstår lærerne slik at i dette utenforfellesskapet, opplever elevene seg selv som deltakende subjekter; de oppnår personstatus.

Når vi setter lærernes synspunkter på integrerende og segregerende praksiser i sammenheng med verdighetstenkning ser vi at de ikke nødvendigvis ser en sammenheng mellom inkluderende opplæring og verdighet, slik CRPD forutsetter. Her er skillet CRPD gjør mellom integrering og inkludering et viktig moment. Segregering oppleves av lærerne som et bedre alternativ for elevene både for å ivareta deres verdighet, beskytte medelevenes verdighet og skape grunnlag for en opplevelse av selvrespekt. Lærerne framhever ikke inkluderende tiltak som en måte å utvikle og sikre elevenes verdighet på. Snarere gjør elevenes tilstand det vanskeligere å finne inkluderende tiltak jo eldre elevene blir. I dette perspektivet kan det i lærernes øyne virke som at retten til inkluderende opplæring står i veien for, heller enn er til gavn for, elever med utviklingshemming. Lærerne selv påpeker ikke her behovet for systemisk endring slik CRPD legger vekt på. Lærerne understreker i stedet at muligheten for inkluderende opplæring i stor grad er avhengig av evnene til den enkelte eleven. Slik kan en si at i lærernes beskrivelse av praksis, kan integrerende praksis opplæring bidra til å true eller svekke elevers opplevelse av verdighet. Dermed blir også praksisen et uttrykk for manglende respekt og anerkjennelse av den enkelte elevs forutsetninger, behov, og dermed hans eller hennes likeverd.

\section{Avslutning: Verdighet og menneskeverd som grunnlag for pedagogisk praksis?}

I denne artikkelen har vi hatt som mål å drøfte inkluderende forståelser av verdighet, og verdighet i læreres pedagogiske praksis i møte med barn med utviklingshemming. Utgangspunktet var det vi mener er et dobbelt spenningsfelt mellom ekskluderende og inkluderende diskurser: verdighetsbegrepet er ikke enhetlig, og tradisjonelle forståelser som påberoper seg universalitet, fokuserer på egenskaper eller idealer som personer 
med nedsatt kognitiv funksjonsevne, avhengig av grad, ikke besitter eller ikke evner å oppnå. Inkluderende opplæring som et ideal som fremmer verdighet kan oppleves å stå i motsetning til spesialpedagogikkens målsettinger.

Vi ønsket å drøfte verdighetsbegrepets anvendelse og betydning både teoretisk og i sammenheng med pedagogisk praksis hvor verdighet/ menneskeverd er en grunnleggende verdi. Tradisjonelle forståelser av verdighet er basert i opplysningstidens humanisme med fokus på autonomi og fornuft, eller på verdighet som noe man oppnår gjennom dannelse. Vi drøftet så inkluderende tilnærminger til verdighet, først med utgangspunkt i menneskelig sårbarhet, kapasiteter og gjensidighet. Deretter presenterte vi tilnærminger som tar utgangspunkt i singularitet, og verdighet som et resultat av opprettholdelsen av rettigheter. I artikkelens andre del drøftet vi verdighet i lys av fem erfarne læreres forståelser av inkluderende/integrerende og segregerende pedagogisk praksis.

I samtalene med disse ble det tydelig at lærerne ikke hadde et bevisst forhold til verdighetsbegrepet. De skjelnet heller ikke mellom integrerende og inkluderende praksis. De beskriver i hovedsak en praksis lik den CRPD beskriver som «integrering.» Lærerne formidlet en generell og tradisjonell forståelse av verdighet, og knyttet den ikke til sin pedagogiske praksis når de ble spurt. Gjennom samtalene formidlet lærerne allikevel en intuitiv forståelse av verdighet som preget deres tanker om integrering og segregering. Med utgangspunkt i Kittays beskrivelse av verdighet i omsorgsrelasjoner, kan en si at gjennom lærernes omsorg og omtanke, formidles verdighet til den enkelte elev. Lærerne gir også uttrykk for en sammenheng mellom tilhørighet og selvrespekt som resonnerer med Nussbaums forståelse av verdighet, og manglende tilhørighet som tap av verdighet og ydmykelse. Lærernes refleksjoner knytter seg til konkrete erfaringer i møte med elever innenfor et eksisterende skolesystem, der inkludering (ifølge Nussbaum, det sosiale grunnlaget for selvrespekt) avhenger av den utviklingshemmede elevens sosiale ferdigheter: De må ha noe å tilby som er attraktivt. Når elevene ikke har dette «noe» er segregerende tiltak stedet hvor elevene opplever verdighet De fem lærerne beskriver også situasjoner der integrering medfører tap av verdighet, enten på grunn av elevenes manglende sosiale ferdigheter, eller 
i situasjoner der de blir objekter i medelevenes læring. I valget mellom integrering som en mangelfull implementering av inkluderende opplæring, og segregering mener lærerne at det er i segregerte opplæringssituasjoner at elevenes verdighet er best ivaretatt.

Kan lærere ha nytte av å drøfte danning og verdighet på inkluderende måter som kan gi muligheter for utviklingshemmedes deltakelse både i ordinær inkluderende opplæring, i egne liv og samfunnet for øvrig etter endt skolegang? Vi mener at inkluderende verdighetsforståelser som kritisk ideal for pedagogisk praksis kan bidra til å realisere målene om inkluderende opplæring som noe som angår alle elever, og som forutsetning for å skape et inkluderende samfunn der utviklingshemmedes erfaringer spiller en rolle.

Eksemplene på inkluderende teoretiske tilnærminger til verdighetsbegrepet har både moralsk og politisk utgangspunkt og hensikt. Kittays omsorgsetikk legger vekt på gjensidighet i mellommenneskelige relasjoner. Dersom denne forståelsen av verdighet skal ha en samfunnsmessig betydning, må den erfares i praksis og læres. MacIntyres forståelse av praktisk dømmekraft i fellesskap, til fellesskapets beste, gir innspill til hva inkluderende opplæring kan bety ikke bare for den utviklingshemmede, men for hele skolesamfunnet. Utgangspunktet hans er utvikling av uavhengig praktisk dømmekraft i erkjennelse egen avhengighet av andre. Selv om han ender opp med å beskrive hva «vi» kan lære av mennesker med utviklingshemming, formidler han en forståelse av praktisk dømmekraft som en felles bestrebelse der også den utviklingshemmedes erfaring og stemme er nødvendig - til fellesskapets beste. Margalit og Kristeva setter krenkelse og ydmykelse i sammenheng med marginalisering og velmenende velgjørenhet. Ved å understreke deltakelse og interaksjon, kan de bidra til en annen forståelse av verdighet og danning som ivaretar alle elevers status og verdighet i deres unike måter å være mennesker på.

\section{Forfatteromtale}

Lena Lybæk er førsteamanuensis ved Institutt for kultur, religion og samfunnsfag, Universitetet i Sørøst-Norge. Hun er programkoordinator for mastergradsprogrammet $\mathrm{i}$ «Human rights and multiculturalism» 
og leder for forskergruppa «human rights and diversities.» Lybæk har en PhD fra Universitetet Durham, UK, og underviser blant annet i kritiske, kulturelle og religiøse perspektivet på menneskerettighetene, og i KRLE i lærerutdanningene. Hun har jobbet med religion og migrasjon, og perspektiver knyttet til religion, kulturelt mangfold og menneskerettigheter i lærerutdanningene. Lybæk har ledet flere internasjonale og lokale utviklingsprosjekter knyttet til de samme temaene. Hun har også en interesse for rettighetene til mennesker med nedsatt kognitiv funksjonsevne.

Åse-May Svendsen er lektor og jobber nå som lærer i vanlig skole. Har 25 års erfaring fra forskjellige undervisningsstillinger. Hun har alltid engasjert seg for elever med spesielle behov, og ønsker å tilrettelegge for en best mulig livskvalitet for denne elevgruppen. Hun har jobbet både med elever med psykisk utviklingshemning som har vært integrert i vanlig barne-/ungdomsskole, elever i spesialklasser på yrkesskole, og med elever som har gått på segregert skole. Åse-May Svendsen har også ca. tre års erfaring som høgskolelektor.

\section{Litteratur}

Bachmann, K., Haug, P., \& Nordahl, T. (2016). Kvalitet i opploeringen for elever med utviklingshemming. (Skriftserie Notat nr. 2). Volda: Høgskulen i Volda.

Barneombudet. (2017). Uten mål og mening. Elever med spesialundervisning $i$ skolen. Barneombudets fagrapport 2017. Hentet fra: http://barneombudet.no/wp-content/ uploads/2017/03/Bo_rapport_enkeltsider.pdf.

Carlson, L. (2010). The Faces of Intellectual Disability: Philosophical Reflections. Bloomington: Indiana University Press.

Davy, L. (2015). Philosophical Inclusive Design: Intellectual Disability and the Limits of Individual Autonomy in Moral and Political Theory. Hypatia, 3o(1), 132-148.

Drejer, E. (1994). Interesser og Identitet. En analyse av Funksjonshemmedes Fellesorganisasjon 1950-1990. (SEFOS Notat. - SEFOS 95, 179). Bergen: SEFOS Senter for samfunnsforskning.

Eknes, J. (2014). Hva er utviklingshemming? Definisjon og begrepsbruk. SOR Rapport (6), 94-101.

Fylling, I. (2008). Meget er forskjellig, men noe blir problem. En sosiologisk studie av spesialundervisningens institusjonelle praksis. (Doktorgradsavhandling). University of Bergen, Bergen. Hentet fra: https://bora.uib.no/handle/1956/3303 
Goble, C. (2004). Dependence, Independence and Normality. I J. Swain, S. French, C. Barnes \& C. Thomas (Red.), Disabling Barriers - Enabling Environments (s. 41-46). London: Sage.

Goffman, E. (1963). Stigma. London: Penguin.

Griffin, J. (2010). On Human Rights. Oxford: Oxford University Press.

Grue, J. (2013). Rhetorics of difference. Julia Kristeva and disability. Scandinavian Journal of Disability Research, 15(1), 45-57. doi:10.1080/15017419.2012.660705

Holstein, J. A., \& Gubrium, J. F. (2003). Active interviewing. I J. A. Holstein \& J. F. Gubrium (Red.), Postmodern Interviewing (s. 66-8o). Thousand Oaks, CA: SAGE Publications, Inc.

ICD-10. (2019). Oslo: Direktoratet for e-helse. Hentet fra: https://ehelse.no/kodeverk/ kodeverket-icd-10-og-icd-11.

Johnsen, B. H. (2010). Annerledeshet og utdanning. Didaktiske muligheter i lys av sårbarhetens politikk. I J. Kristeva \& E. Engebretsen (Red.), Annerledeshet. Sårbarhetens språk og politikk (s. 126-147). Oslo: Gyldendal Akademisk.

Kittay, E. F. (2005a). At the margins of moral personhood. Ethics, 116(October), 101-131.

Kittay, E. F. (2005b). Equality, Dignity and Disability. I M. A. Lyons \& F. Waldron (Red.), Perspectives on Equality. The Second Seamus Heaney Lectures. (s. 93-119). Dubin: The Liffey Press.

Kittay, E. F. (2009). The Personal is philosophical is political: a philosopher and mother of a cognitively disabled person sends notes from the battlefield. Metaphilosophy, 40(3-4), 606-625.

Kittay, E. F. (2011). The Ethics of Care, Dependence, and Disability. Ratio Juris, 24(1), 49-58.

Kristeva, J. (2008). Brev til presidenten. Om mennesker med funksjonshemning. Oslo: Cappelen Akademisk Forlag.

Kristeva, J. (2010). Liberty, Equality, Fraternity and ... Vulnerability. I Hatred and Forgivenes (s. 29-45). New York: Columbia University Press.

Kristeva, J. (2013). A Tragedy and a Dream. Irish Theological Quarterly, 78(3), 219-230.

Lied, I. M. (2012). Variasjoner i funksjonsevne som vilkår: En diskusjon av funksjonshemming og menneskesyn i lys av Martha Nussbaums politiske filosofi. Norsk Filosofisk Tidsskrift, 47(2), 130-142.

Locke, J. ([1689] 2003). The Second Treatise. I I. Shapiro (Red.), Two Treatises of Government and a Letter Concerning Toleration. New Haven: Yale University.

Lorenzen, E. (2008). Psykisk utviklingshemning - hvordan stilles diagnosen? Tidsskriftet den norske legeforening, 128(2), 201-202. Hentet fra https://tidsskriftet. no/2008/o1/kronikk/psykisk-utviklingshemning-hvordan-stilles-diagnosen

MacIntyre, A. (1999). Dependent Rational Animals: Why Human Beings Need Virtues. Chicago and La Salle, IL: Open Court. 
MacIntyre, A. (2007 [1981]). After Virtue (Third edition). Notre Dame, IN: University of Notre Dame Press.

Margalit, A. (1996). The Decent Society. Cambridge, MA: Harvard University Press.

McMahan, J. (2009). Cognitive Disability and Cognitive Enhancement.

Metaphilosophy, 40(3-4), 582-605.

Mittler, P. (2003). Meeting the Needs of People with an Intellecutual Disability: International Perspectives. I S. S. Herr, L. O. Gostin, \& H. H. Koh (Red.), The Human Rights of Persons with Intellecutual Disabilities (s. 25-48). Oxford: Oxford University Press.

NOU (2016: 17). På lik linje. Åtte løft for å realisere grunnleggende rettigheter for personer med utviklingshemming. Hentet fra https://www.regjeringen. no/contentassets/bobaf226586543ada7c53ob4482678b8/no/pdfs/ nou2016201600170oodddpdfs.pdf

Nussbaum, M. C. (1997). Capabilities and Human Rights. Fordham Law Review, 66(2), 273-30o. Hentet fra http://ir.lawnet.fordham.edu/flr/vol66/iss2/2

Nussbaum, M. C. (2003). Capabilities as Fundamental Entitlements: Sen and Social Justice. Feminist Economics, 9(2-3), 33-59.

Nussbaum, M. C. (2006). Frontiers of Justice: Disability, Nationality, Species Membership. Cambridge, Massachussetts: The Belknap Press of Harvard University Press.

Nussbaum, M. C. (2008). Human Dignity and Political Entitlements. I The President's Council on Bioethics (Red.), Human Dignity and Bioethics: Essays Commissioned by the President's Council on Bioethics. Part 4: The Source and Meaning of Dignity. Washington, D.C.: The President's Council on Bioethics.

Rawls, J. (1996). Political Liberalism. Revised edition. New York: Columbia University Press.

Reindal, S. M. (2010). Dilemmaer om ulikhet: Forskjellighet sett i lys av kapabilitetstilnærmingen spm grunnlag for spesialpedagogisk virksomhet. I S. M. Reindal \& R. S. Hausstätter (Red.), Spesialpedagogikk og etikk. Kollektivt ansvar og individuelle rettigheter. (s. 116-132). Kristiansand: Høyskoleforlaget.

Shakespeare, T. (2014). Disability Rights and Wrongs Revisited. Oxford: Routledge. Simplican, S. C. (2015). Capacity Contract: Intellectual Disability and the Question of Citizenship. Minneapolis: University of Minnesota Press.

Singer, P. (2005). Ethics and Disability: A Response to Koch. Journal of Disability Policy Studies, 16(2), 130-133.

tenBroek, J. (1966). The Right to Live in the World: The Disabled in the Law of Torts. California Law Review, 54(2), 841-916. doi:http://dx.doi.org/doi:10.15779/Z384J44

UN, The Committee on the Rights of Persons with Disabilities (2016). General comment No. 4 (2016) on the right to inclusive education. Hentet fra https://tbinternet. ohchr.org/_layouts/15/treatybodyexternal/Download.aspx?symbolno=CRPD/C/ $\mathrm{GC} / 4 \&$ Lang=en 
Utdanningsforbundet. (udatert). Lærerprofesjonens etiske plattform. Hentet fra https://www.utdanningsforbundet.no/globalassets/larerhverdagen/profesjonsetikk/ larerprof_etiske_plattform_a4.pdf

Waldron, J. (2017). One Another's Equals: The Basis of Human Equality. Cambridge, MA: The Belknap Press of Harvard University Press.

Wendelborg, C., \& Tossebro, J. (2008). School Placement and Classroom Participation among Children with Disabilities in Primary School in Norway: A Longitudinal Study. European Journal of Special Needs Education, 23(4), 305-319. doi:10.108o/08856250802387257

Wendelborg, C., \& Tøssebro, J. (2011). Educational arrangements and social participation with peers amongst children with disabilities in regular schools. International Journal of Inclusive Education, 15(5), 497-512. doi:10.1080/13603110903131739

Wetz, F. J. (2005). Illusion Menschenwürde. Aufstieg und Fall eines Grundwerts. Stuttgart: Klett-Cotta.

Wood, A., \& O’Neill, O. (1998). Kant on Duties Regarding Nonrational Nature. Proceedings of the Aristotelian Society, Supplementary Volumes, 1, 72, 189-228.

Young, I. M. (1990). Justice and the Politics of Difference. Princeton, NJ: Princeton University Press. 


\title{
Verdighet i det pluralistiske klasserommet
}

\author{
Geir Winje
}

\section{Universitetet i Sørøst-Norge}

\begin{abstract}
In this essay I will first present two cases from Norwegian school, where someone's dignity may have been violated because of religious differences. I also comment on the use of words and concepts like dignity, human rights and equality of status, in curriculums and text books. After these introductory thoughts, I connect to Peter Schaber, who points out that "the violation of dignity consists in treating others as if they had no normative authority over themselves and over how they are treated" (2014, p. 159f), but also Jeremy Waldron and others who see dignity in the light of equality.

The first case is a documentary produced by NRK (Norwegian Public Broadcasting Corporation) and made accessible for schools. Here we meet two Norwegian women with Vietnamese family background trying to explain their understanding of women's karma, and a sceptic journalist who reacts in a way that may be understood as violating their dignity. The second case is a teacher student's report from a discussion with a school teacher about how pupils belonging to Jehovah's witnesses should be treated when they do not participate in e.g. birthday celebrations.

Both cases show that violation of dignity actually is going on in Norwegian schools, and - more surprising - that it is motivated and legalized by the violator's own value system. I therefore conclude the essay with a distinction between two ways of acting in accordance with modern humanist values: a deontological or "listening humanism" versus a teleological or "preaching humanism".
\end{abstract}

Keywords: Dignity, school curriculum, religious education, human rights

I denne artikkelen belyser jeg følgende problemstilling: Kan norske skoleelevers verdighet krenkes på grunn av religionsforskjeller? For å kunne gi et svar, undersøker jeg to kasus som ble rapportert av lærerstudenter etter en praksisperiode. Jeg ser også på hvordan verdighet og beslektede begreper brukes i Menneskerettighetserklæringen, opplæringsloven,

Sitering av denne artikkelen: Winje, G. (2019). Verdighet i det pluralistiske klasserommet. I A. Valen-Sendstad \& I. R. Christensen (Red.), Menneskeverd - en utfordring for skole og samfunn (Kap. 4, s. 99-118). Oslo: Cappelen Damm Akademisk. https://doi.org/10.23865/noasp.9o.ch4.

Lisens: CC BY-NC 4.0. 
læreplanverket og lærebøkene. Deretter undersøker jeg hvordan verdighet og krenking av verdighet forstås i pågående akademiske diskusjoner. Her finner jeg definisjoner, fortolkninger og presiseringer som jeg tar i bruk i analysen av de to kasusene. ${ }^{1}$ Et uventet funn er at de samme humanistiske ideer og verdier som ligger til grunn for tanken om iboende verdighet og like rettigheter, også legitimerer krenkelse av disse.

\section{Innledende om to kasus}

Analysen av de to kasusene nevnt ovenfor utgjør artikkelens tyngdepunkt. Det ene kasuset er en episode fra dokumentarserien På tro og Are, produsert av NRK og gjort tilgjengelig som undervisningsprogram for skoleelever (nrk.no/skole). I denne episoden tilbringer programleder Are Sande Osen mye tid sammen med to buddhistiske jenter fra Trondheim. Filmen åpner i en gemyttlig tone, Osen virker vennlig og nysgjerrig på sine informanter, men stemningen snur når han begynner å kritisere jentenes forståelse av karma som årsak til manglende likestilling mellom kjønnene.

Det andre kasuset er (referatet fra) en samtale mellom en grunnskolelærerstudent og en praksislærer om hvordan de bør forholde seg til en elev med tilhørighet $i$ Jehovas vitner når det feires bursdag $i$ klassen. Studenten foreslår et opplegg som vil gi alle elevene innsikt i hvorfor Jehovas vitner ikke feirer fødselsdager, men læreren ønsker ikke at trossamfunnet skal få eksponere seg.

Grunnen til at nettopp disse to kasusene ble valgt, var at de utløste større diskusjoner enn hva de andre fremleggene gjorde i den aktuelle studentgruppen. Det var ingen studenter som forsøkte å kartlegge eller forstå hva som egentlig hadde skjedd, eller hvorfor det skjedde, men det var mange som opplevde begge situasjonene som dilemmaer: På den ene siden er det $\mathrm{i}$ samsvar med humanistiske verdier å motarbeide alt som kan hindre likeverd og likestilling - også religioner som forfekter et førmoderne syn på kvinner og barn. På den andre siden er det i samsvar med humanistiske verdier å sikre religionsfrihet også for mennesker og trosformer som ikke

$1 \quad$ Jeg bruker her KRLE (kristendom, religion, livssyn og etikk) synonymt med tidligere navn på faget: KRL (kristendomskunnskap med religions- og livssynsorientering), KRL (kristendom, religion og livssyn) og RLE (religion, livssyn og etikk). 
synes å bry seg særlig om kvinners og barns rettigheter. Selv opplevde jeg først og fremst at vi manglet et felles språk på dette feltet.

\section{Innledende om verdighet i skolen og $i$ menneskerettighetserklæringen}

Elever i norsk skole skal både erfare verdighet og lære om verdighet. Erfaringen kan forankres i Generell del av loereplanen, der det heter: «Oppfostringa skal byggje på det syn at menneske er likeverdige og menneskeverdet ukrenkjeleg.»² Det betyr, slik jeg forstår det, at hver enkelt elev til daglig skal behandles på en måte som gjør det tydelig for alle og enhver at han eller hun er like verdifull som alle de andre - uavhengig av religionsforskjeller, grad av skoleflinkhet eller andre ulikheter. En svakhet ved denne setningen er at den ikke begrunner hvorfor menneskeverdet er ukrenkelig og alle mennesker likeverdige.

Verdighet som faginnhold kan forankres i læreplanene for samfunnsfag og KRLE. I KRLE skal elevene på 1.-4. årstrinn kunne «bruke FNs barnekonvensjon for å forstå barns rettigheter og likeverd (...)» og på ungdomstrinnet skal de lære å «drøfte etiske spørsmål knyttet til menneskeverd og menneskerettigheter, likeverd og likestilling (...)».

Likeverd er viktig blant annet fordi det kan begrunne lik stilling og status, men verken stilling eller status kan begrunne verdi eller verdighet. Det gir derfor mening å se disse prinsippene i sammenheng med Menneskerettighetserkloeringen fra 1948. Jeg siterer to korte utdrag fra innledningen pluss artikkel 1:

Da anerkjennelsen av iboende verdighet og av like og uavhendelige rettigheter for alle medlemmer av menneskeslekten er grunnlaget for frihet, rettferdighet og fred i verden (...)

De Forente Nasjoners folk i Pakten på ny har bekreftet sin tro på grunnleggende menneskerettigheter, på menneskets verdighet og verdi og på like rettigheter for menn og kvinner og (...)

2 udir.no/laring-og-trivsel/lareplanverket/generell-del-av-lareplanen/det-meiningssokjande-mennesket/ (lest 19.9.2019). Artikkelen ble skrevet samtidig med at ny læreplan («Fagfornyelsen», gjeldende fra 2020) ble utviklet. 
Alle mennesker er født frie og med samme menneskeverd og menneskerettigheter. De er utstyrt med fornuft og samvittighet og bør handle mot hverandre i brorskapets ånd. ${ }^{3}$

Nøkkelbegrepene i disse sitatene kan ordnes i to ledd, det ene leddet forut for og forutsetning for det andre. Det første leddet gjelder selve menneskeverdet, prinsippet, hva det er og hvordan det begrunnes. Her er begrepene «iboende verdighet» og «samme menneskeverd» sentrale. Jeg velger også å plassere begrepet «likeverd» i denne kategorien, selv om det ikke brukes i erklæringen. Det brukes derimot i læreplan og lærebøker (se nedenfor). Hva som menes med «iboende», og om dette uttrykket innebærer en form for begrunnelse, kan selvsagt diskuteres nærmere. Begge formuleringene forhindrer i hvert fall en gradering av menneskeverdet.

Det andre leddet utledes av det første. I denne menneskerettighetsdiskursen innebærer likt menneskeverd lik tilgang til konkrete menneskerettigheter, noe som er tydelig i uttrykkene «like og uavhendelige rettigheter for alle (...)», «grunnleggende menneskerettigheter» og «samme (...) menneskerettigheter».

Begrunnelser er nødvendige når en skal arbeide med menneskerettigheter i en undervisningssituasjon. Samtidig kan begrunnelser fungere som betingelser. Hva med de som ikke har mulighet til å praktisere den medfødte friheten som nevnes aller først i erklæringen, eller de som har liten eller ingen samvittighet eller fornuft?

Menneskets verdi kan også begrunnes i religiøse forestillinger, for eksempel at det er skapt i Guds bilde (Første Mosebok kap. 1) eller har en guddommelig sjel (Jacobsen, 2009, s. 107ff). Det er imidlertid problematisk at religionene stort sett sorterer mennesker i kategorier med ulik status og verdi, avhengig av for eksempel hvor hellige eller lydige de er (Lybæk, 2017).

\section{Verdighet i lærebøkene}

Elevene lærer relativt lite om dette på skolen, i hvert fall om vi ser lærebøkene som indikatorer. Det nevnte kompetansemålet for ungdomstrinnet

3 www.fn.no/Om-FN/Avtaler/Menneskerettigheter/FNs-verdenserklaering-om-menneskerettigheter (lest 24.10.2019). 
(«drøfte etiske spørsmål knyttet til menneskeverd og menneskerettigheter, likeverd og likestilling (...)») medfører at menneskeverd og likeverd tas eksplisitt opp i KRLE-lærebøker for 8.-10. årstrinn. Heller ikke her begrunnes menneskets verdighet, derfor legges det heller ikke opp til noen undersøkelse av eller diskusjon om begrunnelser, noe som betyr mindre grundig læring.

Begge de to mest brukte læreverkene for ungdomstrinnet har (del) kapitler med overskriften «Likeverd og likestilling». Begge innledes med en setning eller to om likeverd, i Horisonter 8 definert som «tanken om at alle har like stor verdi og er like verdifulle» (Holth \& Deschington, 2006, s. 112). I KRL-boka 8-10 (som viderefører Under samme himmel 1, 2 og 3) heter det at «menneskerettighetene har som sitt grunnlag at alle mennesker er like mye verdt. Likeverd betyr at alle er like verdifulle uansett kjønn, seksuell orientering, rase, nasjonalitet, stilling eller status» (Wiik \& Waale, 2016, s. 36). Resten av de to kapitlene på henholdsvis fire og åtte sider er viet likestilling, først og fremst mellom kjønnene. Horisonter 8 begrunner da også dette med at i Norge henger likeverd «nøye sammen med likestilling» (Holth \& Deschington, 2006, s. 115).

Lærebøkenes prioriteringer tyder på at elevene lærer mer om - eller i hvert fall hører mer om - likestilling enn om likeverd. Det er derfor sannsynlig at de utvikler høyere kompetanse på å oppdage og motarbeide manglende likestilling enn manglende likeverd. Likestilling kan virke mer konkret og målbart enn likeverd. Det er derfor behov for en definisjon av likeverd som ivaretar begrepets betydning og dets funksjon som forutsetning og begrunnelse for like rettigheter og likestilling. Det bør samtidig være så enkelt at det er håndterbart for 15 år gamle elever.

\section{Metode}

Denne undersøkelsen er gjennomført uten mye metodisk ballast. Metodisk sett kan den karakteriseres som poststrukturalistisk og eklektisk (Knudsen, 2010, s. 179). Den beskrives kanskje best som tre til dels overlappende faser, der den første er en forberedelsesfase preget av faglig input. I løpet av denne fasen kom jeg over en artikkel av Peter Schaber som ga prosjektet en viss retning (se nedenfor). Den andre fasen er abduktiv og 
eksplorativ (Laursen, 2010-2017). Her undersøker jeg lærebøker, praksisfortellinger og andre kasus som ikke tidligere er undersøkt med dette for øye. Under den tredje og avsluttende fasen lanseres gjerne nye hypoteser fremfor konklusjoner.

\section{Nærmere om verdighet og krenkelse av verdighet}

Peter Schaber, professor i filosofi ved Universitetet i Zürich, skriver i «Human Rights and Human Dignity» (2014, s. 159f):

Acts of degradation or humiliation are paradigm violations of dignity. As Waldron [se nedenfor] puts it, "A good account of human dignity will ... generate an account of the ban on humiliating and degrading treatment." Acts of degradation and humiliation do not just impair the interests or the autonomy of the victims: they strike at the moral status itself. By acts of degradation we treat others as if they had no say, as if we had the right to treat them in whatever way we please. The violation of dignity consists in treating others as if they had no normative authority over themselves and over how they are treated. I think that it is this normative authority which is meant by dignity and which is paradigmatically disrespected by acts of degradation and humiliation. By treating individuals in this way one denies the existence of any normative authority on their part. It seems to me that this idea of normative authority is more central to the understanding of human rights than other things such as basic needs or interests.

Schaber skriver her mer om krenkelse av verdighet enn om verdighet som sådan, men nettopp derfor er teksten såpass konkret. Definisjonen skjelner heller ikke mellom «små» og «store» saker, og den kan forenkles på flere måter, for eksempel slik: Den enes verdighet krenkes når den andre tar valg på vegne av den ene som om den ene ikke er $i$ stand til å ta valg på vegne av seg selv. Schabers definisjon virker dessuten religionsuavhengig, siden den er uten referanser til hellige skrifter eller lignende. Krenkelse av verdighet forstås imidlertid som et hinder for frihet og individualitet, altså typisk vestlige, humanistiske verdier. Disse verdiene omfatter også 
religionsfrihet, selv om religionene selv kan neglisjere den enkeltes frihet (Lybæk, 2016).

Dersom «the violation of dignity consists in treating others as if they had no normative authority over themselves and over how they are treated», krenkes elever i norsk skole kontinuerlig, da de har liten eller ingen innflytelse på undervisningens mål eller rammer. Men fordi dette gjelder alle elever, oppleves det ikke nødvendigvis som krenkelse. Opplevd krenkelse synes derimot å henge sammen med forskjellsbehandling: Elever opplever seg krenket når de erfarer at de samme reglene ikke gjelder for alle. Lik verdighet (jf. likeverd) forstått som lik status (lik stilling, likestilling) står sentralt i elevers verdighetsdiskurs, og som vi har sett, har lærebøkene en lignende forståelse. Når KRLE-boka hevder at «likeverd betyr at alle er like verdifulle uansett kjønn, seksuell orientering, rase, nasjonalitet, stilling eller status» (se ovenfor - Wiik og Waale, 2016, s. 36, min uthevelse), fastslår den tilsynelatende uforstyrret at likeverd $i k k e$ forutsetter lik status eller rang.

Forholdet mellom verdighet og likhet er uklart og diskuteres derfor mye, blant andre av Michael Rosen, professor i filosofi ved Harvard, som tar opp dette $\mathrm{i}$ «Dignity and Equality» (i Dignity: Its History and Meaning, 2002) og Jeremy Waldron, professor ved New York University School of Law. Sistnevnte vil i Dignity, Rank, and Rights (2012) ikke bare at alle mennesker tilkjennes den samme verdighet, men han vil at alles status skal heves:

(...) the modern notion of human dignity involves an upwards equalization of rank, so that we now try to accord to every human being something of the dignity, rank, and expectation of respect that was formerly accorded to nobility.

Når jeg i det følgende undersøker om de to kasusene fra studenters praksis faktisk handler om krenkelse av verdighet, bruker jeg Schabers definisjon av krenkelse («degradation», «humiliation», «treating others as if they had no normative authority over themselves») som hovedkriterium, særlig i forbindelse med det første kasuset. Likestilling (likhet eller lik status, jamfør Waldron's «equalization of rank») brukes i mindre grad, men er aktuelt i begge kasus. 


\section{En film om buddhisme}

NRK sendte i 2010 den første sesongen av På tro og Are, seks 30 minutters programmer der programleder Are Sende Osen besøker familier som er muslimer, mormonere, sikher, jøder, pinsevenner og buddhister. Serien består (foreløpig?) av tre sesonger, produsert av NRK i samarbeid med Ekkofilm. Den første sesongen introduseres slik:

Hva skjer når en selverklært ateist og skeptiker tilbringer en uke sammen med en sterkt religiøs familie og deres miljø? Are reiser rundt i Norge og tilbringer én uke med seks ulike religioner. Hans håp er å finne ut hva det er de tror på, hvorfor de tror, om de har noe han ikke har eller om det er nettopp så galt som han hadde trodd. ${ }^{4}$

Programmene er siden sendt i reprise, og kan i dag lastes ned fra Internett, både som allmenn-TV (tv.nrk.no) og som undervisningsprogram (nrk.no/skole). Grunnskolelærerstudenter rapporterer fra praksis at filmene brukes mye i skolen, ofte uten at læreren kommenterer dem.

Are spiller seg selv som en slags gonzo-journalist, og seerne blir i løpet av serien mer kjent med ham enn med menneskene han besøker. Han virker liketil og folkelig, bevisst på sine fordommer. Samtidig er han lyttende og nysgjerrig på andre mennesker og deres religion. De fem første programmene ender alle med at Are avslutter sine besøk med å si til familien han har bodd hos at han har lært mye om deres tro og fått større respekt for religionen deres enn han hadde ventet. Han feller altså en dom - riktignok på et veldig tynt grunnlag - over den religionen han nettopp har møtt. Den vurderes som god dersom religionens verdier har mye til felles med Ares egne verdier, og dommen fremstår derfor som etnosentrisk.

Det sjette programmet beskrives slik på NRKs nettsted:

I dag reiser Are med to vietnamesiske jenter til Norges største buddhist-tempel for å feire Buddhas fødselsdag med pomp og prakt. Og Are prøver å forstå dette med karma. ${ }^{5}$

\footnotetext{
4 ekkofilm.no/?avada_portfolio=pa-tro-og-are (lest 26.10-2019).

5 tv.nrk.no/serie/paa-tro-og-are/sesong/1/episode/6 (lest 24.10.2019).
} 
Are virker i utgangspunktet positiv til buddhismen, som jo er en relativt populær religion i Vesten. Et vendepunkt kommer i det øyeblikket den ene kvinnen forklarer at det er vanskeligere for kvinner å leve som nonner enn det er for menn å leve som munker, og at dette gjør det vanskelig for kvinner å utvikle god karma. Are reagerer kraftig på det kvinnesynet han synes å se bakom en slik forståelse av karma, og filmen endrer nå karakter. Fra å være en informativ dokumentar om norske buddhister går den over til å bli en kritisk debattfilm om Buddhas lære.

Resten av filmen vender Are hele tiden tilbake til dette temaet - ikke for å «forstå dette med karma» som det heter i følgeteksten, men for å få de to kvinnene til å innse hvor umenneskelig religionen deres er. Etter en lengre utlegning om at karmaloven kan forklare hvorfor noen fødes i fattigdom og nød, spør han: «Kan man si til et lite [sultende] spedbarn at det har seg selv å takke fordi det var så dumt i sitt forrige liv?» Han virker faktisk overrasket over at buddhismen diskriminerer mellom menn og kvinner, og til hans forskrekkelse forklarer søstrene hvor mye mer krevende det er å være nonne enn å være munk, blant annet fordi kvinner blir fortere irriterte enn menn. I en scene slipper også søstrenes mor til med sitt ønske om at de må bli nonner i stedet for å gifte seg med hver sin mann.

Are og de to søstrene drar så på biltur fra Trondheim til Løvenstad der de skal feire vesak - «med pomp og prakt», ifølge NRK. Turen preges av Ares kritiske spørsmål. Når de etter en lang dag kommer frem, håndhilser han på munken som er søstrenes veileder. Den ene søsteren viser ham umiddelbart hvordan det er vanlig å hilse munker, nemlig med håndflatene mot hverandre i brysthøyde og en lett bøy i overkroppen. Deretter sier Are: «Unnskyld», og så hilser han på riktig måte. Denne korte hilsescenen kan ha to tilsiktede funksjoner: $\AA$ vise at skikk og bruk er forskjellig fra kultur til kultur, eller å tydeliggjøre at menn, i hvert fall munker, har høyere status enn kvinner. Hilsningsmåten, der den ene bøyer seg for den andre, men ikke omvendt, visualiserer ikke akkurat likestilling mellom den religiøse eliten og lekfolket. På den annen side legger filmen på denne måten makt og myndighet til munker, og ikke til kvinnelige lekfolk, og dermed legges også ansvaret for det som måtte være galt i buddhismen på dem. 
Når Are tar opp dette med karma og kjønn med munken, får han bekreftet at det søstrene har fortalt, er i samsvar med religionens hellige skrifter. Munken er nøye med å understreke at buddhismens budskap, som inkluderer denne forståelsen av karma og kjønn, kun har relevans for de som velger å følge Buddhas lære. Han ler mye mens han gjør rede for dette, noe som er uvanlig i en norsk religionskontekst, og derfor vanskelig å tolke.

Filmen fader ut med selve vesak-feiringen, og Are tar farvel med sine to informanter. Det siste han sier til dem er at hvis han fikk bestemme, så skulle de ikke bli nonner. Når han er utenfor hørevidde, advarer han mot å fokusere på forrige eller neste liv, men heller på det livet vi lever her og nå. Deretter oppsummerer han:

Oppholdet mitt sammen med buddhistene ble ikke som jeg hadde håpet. De var utrolig vennlige og likendes folk, men når det kommer til trua deres, så ble jeg ikke imponert. Å si at noen som har det fælt kan takke seg sjøl fordi de har gjort noe gæli i et tidligere liv, faller på sin egen urimelighet.

\section{Krenkes buddhistene?}

Både mennesker og religioner som lar seg portrettere i media, må tåle kritikk. Når det er fare for krenkelse av menneskeverdet, er det ikke graden av uenighet som avgjør, men måten man behandler hverandre på. Da munken i en samtale i etterkant av produksjonen fortalte at det meste av det han hadde forklart om karma var blitt klippet bort, uten at han fikk delta i redigeringsprosessen eller godkjenne det endelige resultatet, var det tydelig at han var blitt utsatt for at «we [her: NRK] treat others as if they had no say, as if we had the right to treat them in whatever way we please» (Schaber, 2014). Slik filmen nå foreligger, er den preget av ytterligere tre grep som kan forsterke opplevelsen av krenkelse:

Eksotisering finner sted når en religion fremstilles som eksotisk og fremmedartet. Da skapes det avstand til den - uavhengig av om de eksotiske trekkene fremstår som positive eller negative. Eksotisering er et uttrykk for orientalisme, og inngår gjerne i etnosentriske diskurser. Eksotisering er derfor et godt eksempel på «Othering» (Said, 1974; Wilkinson \& Kitzinger, 1996). De to søstrene skriver om dette i en klage til NRK: 
Vi ble også presset av Are Osen til å stille opp på opptak som ikke gir noe godt bilde av buddhismen. Da vi besøkte tempelet i Lørenskog ville han at vi skulle vise ham spådomspinner som er en del av vietnamesisk folketro som ikke handler om buddhisme. Vi syntes ikke at dette ga noe riktig bilde av buddhismen og ble derfor skuffet over at NRK sendte opptak av dette mot vårt ønske. ${ }^{6}$

Demonisering finner sted når en religion eller de som leder den, tillegges ond vilje. De kan for eksempel beskyldes for å bruke sine tilhengere som midler til å oppnå egne mål, det være seg økonomiske eller andre. De som bekjemper en demonisk religion, gjør i egne øyne noe godt. Det er ikke så lenge siden ikke-kristne religioner ble demonisert i skolens lærebøker fordi de var forskjellige fra kristendommen. I løpet av 1970-årene endret dette seg, og religionene ble i stedet kritisert for sine ikke-humanistiske verdier (Winje, 2011). Ares kritikk er typisk fordi han bruker humanistiske kriterier når han kritiserer buddhismen. Det kan virke som om likeverd og særlig likestilling for ham er overordnede verdier, mens Buddhas lære (dharma) er viktigst for de to søstrene og munkene. Kildene til dharma er 2500 år gamle læretekster (sutraer) som bærer med seg samtidens forestillinger om blant annet kjønn, selv om budskapet ikke gjelder kjønn direkte.

Karikering finner sted når den som kritiserer en religion, mangler kunnskap om den, og derfor kritiserer en karikatur. Et godt eksempel er Ares oppsummering av karma: «... noen som har det fælt kan takke seg

6 Utdrag fra klagen som ble sendt fra de to søstrene 29.12.2010: «Selv om ikke vi er eksperter på buddhisme sa vi ja til å stille opp fordi programmet bare skulle vise hvordan en buddhistfamilie lever i hverdagen (...) I stedet ser vi at programmet stort sett handler om en diskusjon om buddhistisk lære. En ting er læren om karma som ikke er så lett å forklare på en enkel måte. Vi hadde ønsket at dette temaet hadde blitt behandlet på en bedre måte ved at buddhistiske lærde fikk uttale seg. Noe annet er hvordan det vi sa om forskjell mellom menn og kvinner er blitt vinklet i programmet. Når vi snakket om forskjell mellom menn og kvinner handlet det om at kvinner har vanskeligere enn menn for å tilpasse seg livet i et tempel. Vi har ikke sagt noe om at kvinner er dårligere eller dummere enn menn. Dette mener vi slett ikke. Vi ble derfor virkelig sjokkert når vi så at Are Osen tolket det vi sa på en slik måte. Vi synes også at det var helt forferdelig at Are Osen koblet det vi sa sammen med påstandene hans om at 'kvinner ikke er i stand til [å] forstå eller praktisere læra hans' og at 'kvinner er mentalt underlegne menn' (...) Vi synes det er veldig trist at NRK har sendt dette programmet. Vi synes også det er ille at dette programmet blir brukt av skolene når det gis et så negativt og feil bilde av hva vi står for. Vi ber derfor NRK rette opp det dårlige og uriktige bilde det har skapt av buddhismen og vietnamesiske buddhister.» (Hentet fra buddhistforbundet.no/article/show/139/Klage-p----P---tro-og-Are---episode-6-fra-de-to-kvinnene-som-deltok-i-programmet - lest 17.2.17) 
sjøl fordi de har gjort noe gæli i et tidligere liv». Her vurderer han en østlig religion ved hjelp av vestlige kriterier og overser blant annet at intensjon er avgjørende for karmiske konsekvenser. Det virker heller ikke som om han har fătt tak i dette med utveksling av karma eller felles karma, som er viktigere i mahayana-buddhismen enn i theravada-buddhismen (Jacobsen, 2000, s. 112f).

Fordi Ares karikerte versjon av buddhismen gjentas flere ganger, fordi han får det siste ordet, og fordi han er den som feller dom over de andre religionene i programserien, blir Ares forståelse stående som en slags fasit. De troende buddhistene, som tar karma alvorlig, blir derimot fremstilt som ofre som har latt seg lure av sin religion.

Problemet er ikke filmen som sådan. Det er behov for flere, ikke færre, religionskritiske innspill i KRLE. De er nødvendige supplementer til de mer religionsvennlige lærebøkene. Problemet er at Are har så lite kunnskap om buddhismen - uten at han skjønner det selv. Å bruke ufaglige filmer i skolen blir litt som å bruke lærere uten fagkunnskap. Det er også problematisk at filmen ikke er tydelig på at den er religionskritisk, selv om den i hovedsak formidler programlederens reaksjoner på deler av buddhistisk lære.

KRLE skal ifølge gjeldende læreplan være «objektivt, kritisk og pluralistisk»? NRK-dokumentaren er kritisk, men den klarer ikke å kombinere den kritiske holdningen med objektivitet. Den klarer heller ikke å innta et - eller rettere sagt flere - pluralistiske perspektiver. Den kan virke tolerant fordi den aksepterer at trosforestillinger varierer, men toleransen gjelder ikke verdipluralisme (Valen-Sendstad, 2017).

I masteroppgaven «På tro og Are» i religionsundervisninga (2017) siterer Jorunn Marie Grønntun sju vgs-elever som har sett På tro og Are, episode 6, sesong 1 (s. 53f). Til spørsmålet: «Kva vekte mest merksemd i episoden?» sier alle sju noe om «kvinnesynet». De ble også bedt om å gjøre rede for om de fikk noe «innblikk i religionen» etter å ha sett episoden om buddhisme. Tre av svarene lyder slik:

(1) Karma er ein veldig viktig del av religionen. For å få god karma hjelper ein andre med ulike ting, men også seg sjølv. Når ein har god karma får ein eit betre

7 www.udir.no/klo6/RLE1-o1/Hele/Formaal (lest 24.10.2019). 
neste liv. Dette verkar eigentleg ganske bra for samfunnet. Men kvinnesynet i buddhismen har eigentleg øydelagt ganske mykje for mitt syn på religionen.

(2) Eg fikk eit nytt syn på buddhismen - eit negativt då eg er ueinig i kvinnesyn og generelt karma. Eg var klar over deira syn på karma og atterføding, men ikkje at dei «forklarar» at tsunami, fattigdom og andre vonde ting skjer på grunn av dårlig karma. Kvifor skal ein lide i sitt «nye» liv pga. eit tidlegare liv ein ikkje hugsar.

(3) I mitt tilfelle forandra eg fullstendig syn på buddhismen, i og med at i bøkene står religionen fram som veldig fin og harmonisk, men at i verkelegheita får ein høyre på tankane og meiningane deira om ulike ting, slik som synet på kvinner. og ein kan lett sjå i episoden at dei føler seg undertrykte, sjølv om dei kanskje ikkje seier det.

Disse sitatene dokumenterer langt på vei at elevene ikke skjelner mellom buddhismen slik den forklares av informantene i filmen, og buddhismen som sådan. De viser også at elevene har uforholdsmessig stor tillitt til dokumentarsjangeren. I sitat 3 settes den idylliserende læreboka opp imot den realistiske dokumentaren, og i sitat 2 refereres det Are sier i filmen og ikke det buddhistene selv sier. Grønntun var i utgangspunktet opptatt av elevenes refleksjoner rundt bruken av dokumentarer, men har likevel dokumentert hvordan så å si alle som så filmen i forbindelse med prosjektet hennes, endret syn på buddhismen, men ikke på dokumentarsjangeren.

\section{Jehovas vitner og feiringer}

Det andre kasuset jeg ser på i denne artikkelen, er en samtale mellom en lærerstudent og en praksislærer om hvordan skolen bør forholde seg til elever med tilhørighet i Jehovas vitner når det gjelder fødselsdager, jul, 17. mai og så videre (Ringnes \& Sødal, 2007). ${ }^{8}$ Erfaringsmessig opplever mange lærere det som ekstra vanskelig å samarbeide med foreldre

8 Sitatet fra rapporten/samtalen er egentlig deler av to sitater som er limt sammen. Årsaken er at to studenter som støtte på den samme problematikken valgte å kombinere tekstene sine. Det ble da merkbart enklere å skrive, rom for flere synspunkter, og vanskeligere å identifisere skoler, lærere og studenter. 
og barn i dette trossamfunnet, både fordi det virker strengere enn andre trosretninger, og fordi symbolsaker som ikke å delta i feiringer viser at de ikke nødvendigvis ønsker full inkludering. ${ }^{9}$ Jehovas vitner ønsker integrering, ikke assimilering. De vil både tilhøre skolefellesskapet og samtidig markere at de ikke deler majoritetens verdier og interesser.

Denne holdningen har mye til felles med de aller første kristnes holdning til majoritetssamfunnet. De eldste kristne tekstene (deler av brevlitteraturen i Det nye testamente) reflekterer en tvetydighet: På den ene siden var dommedag så nær forestående at alt annet enn å forberede seg på den, var bortkastet tid. På den andre siden utgjorde de første kristne en minoritet i et flerkulturelt storsamfunn som de måtte forholde seg til. De provoserte både jødiske (religiøse) og romerske (politiske) myndigheter med sin tro på at Jesus snart skulle overta kongemakten. De markerte avstand til det romerske overherredømmet ved heller å dø enn å hilse keiseren som en gud. Og de brøt med jødedommen, moderreligionen, ved å oppheve spiseregler og andre forbud og påbud fra Moseloven. Ett forbud ble imidlertid videreført av de kristne, og det gjaldt inntak av blod (se 3 Mos. 17:14 og Apg. 15:28f). Derfor gjelder dette budet også for Jehovas vitner i dag.

Jehovas vitner viderefører i egne øyne den samme doble holdningen til samfunnet. Et ideal er å være $i$ verden, men ikke $a v$ verden (se Joh. 17). Elever med bakgrunn i Jehovas vitner lærer hjemme at de tilhører et annet rike enn de andre i klassen, nemlig Guds rike, som snart skal beseire Satans rike.

For skolen og den enkelte lærer kan det være vanskelig å tilrettelegge undervisning og andre aktiviteter på en slik måte at disse elevene opplever seg verdsatt både som del av fellesskapet og som outsidere. Det kan oppleves som ekstra uheldig at trossamfunnets merkesaker innebærer å avstå fra feiringer som tradisjonelt er brukt til å bygge fellesskap, både i skolen og i samfunnet for øvrig. Med innvandringen de siste 50 årene har det imidlertid blitt mange nordmenn som ikke

9 «Mangfold» og «inkludering» er begreper som brukes mye i styringsdokumenter og annen litteratur om barnehage og skole. Tidligere dominerte begrepene «integrering», «assimilering» og «segregering», som til sammen fanger opp flere nyanser og som derfor brukes mest i denne artikkelen. 
feirer alle de typisk norske høytidene og merkedagene. I det følgende utdraget fra en anonymisert praksisrapport kommer ulike holdninger til syne:

En student var vitne til at en elleve år gammel gutt med tilhørighet i Jehovas vitner satt ved pulten sin og så brydd ut mens resten av klassen sang «Hurra for deg som fyller ditt år» for en annen elev. Bursdagsbarnets mor hadde tatt med gelé og vaniljesaus, mer enn nok til alle. Ingen krone var å se, det hadde de sluttet med etter 4 . klasse. Feiringen var heller ikke langdryg, men studenten (S) spurte etterpå:

$S:$

Er det ikke lurt å be ham [gutten fra Jehovas vitner] fortelle i klassen om hvorfor han ikke feirer bursdag, da blir det kanskje enklere for både ham og oss andre?

Praksislærer (P): Da jeg var helt fersk som lærer, husker jeg at jeg lurte foreldrene til en jente som ikke fikk lov til å feire bursdager. Jeg lot henne få være med på det hun ville, og hun ville være med på mye, særlig bursdager - men hun ville ikke gå $\mathrm{i}$ kirken. Vi snakket aldri om det, men vi visste begge to at foreldrene ikke måtte få vite om det. Etter et års tid måtte jeg slutte med det, for da fikk jeg flere Jehovas vitner-familier i klassen

S: Var det lov, det du gjorde, da?

P: $\quad$ Jeg vet ikke, det var kanskje i en gråsone. Jeg ville jo bare hjelpe eleven så hun skulle føle seg mindre utenfor.

S: $\quad$ Kanskje vi skulle be ham eller foreldrene hans om å komme i en KRLE-time. De kunne forklare noe av det vi har lagt merke til, men ikke skjønner helt, sånn som at de ikke feirer bursdag? Eller kanskje vi skulle be dem si noe på et foreldremøte?

P: $\quad$ Nei, det blir ikke noe bra. Mange vil nok bli provosert hvis Jehovas vitner får bruke skolen som talerstol.

S: $\quad$ Men dette kan vi kalle informasjon, vi kan be dem om å ikke blande inn noe forkynnelse.

P: $\quad$ Nei, jeg tror ikke det er så lurt.

Jeg synes denne samtalen viser hvor lite som skal til før religionspluralisme blir opplevd som så krevende at det vanskeliggjør arbeidet med å 
synliggjøre likeverd elevene imellom. Praksisrapporten inneholder for øvrig flere eksempler på posisjoner som gjerne inntas i møte med elever fra trossamfunn som ikke isolerer seg, men som heller ikke lar seg assimilere. En annen måte å si det på er at de ser en viss grad av segregering som et uttrykk for likeverd.

Særlig praksislæreren inntar ulike posisjoner i løpet av samtalen. Hun markerer innledningsvis en form for solidaritet med disse elevene, men ikke med deres foreldre, som hun senere stiller seg skeptisk til å la komme til orde. Lærerstudenten synes på sin side å handle ut ifra en overbevisning om at respekt forutsetter forståelse, og at forståelse forutsetter kunnskap. Studenten ønsker å markere likeverd ved å tydeliggjøre ulikheter, mens praksislæreren i større grad ser likhet som en forutsetning og sannsynlig konsekvens av likeverd. De synes begge å ønske integrering, men praksislærerens forståelse av integrering ligger nærmere assimilering enn studentens forståelse.

Videre virker studenten mer opptatt av lover og forskrifter, mens læreren i større grad følger sin egen samvittighet og dømmekraft. En tredje motsetning mellom de to kommer til syne når praksislæreren synes synd på eleven som ikke får feire fødselsdag, mens studenten forsøker å se det hele fra foreldrenes side. De ønsker i prinsippet at barna deres skal bli trygge og kanskje stolte som Jehovas vitner. I lys av opplæringslovens klare påbud om at skolen skal operere «i samarbeid og forståing med heimen», vil jeg hevde at praksislæreren gjør eleven en bjørnetjeneste når hun motarbeider foreldrene ved å omgå de forbudene religionen deres setter. Selv om lærerens hensikt er å «hjelpe eleven så hun (...) [føler] seg mindre utenfor», og selv om eleven skulle oppleve det på samme måte der og da, kan lærerens atferd på sikt skape eller forsterke en lojalitetskonflikt mellom hjem og skole.

Samtalen mellom student og praksislærer viser også at begge har en humanistisk grunnholdning, i det de forsøker å ivareta elevers verdighet - om enn på svært forskjellige måter. Om vi legger den forenklede formuleringen av Schabers definisjon (ovenfor) til grunn, ser vi at hun i større grad enn studenten tenderer mot å ta valg på vegne av den ene som om den ene ikke er $i$ stand til å ta valg på vegne av seg selv. 


\section{Avsluttende om krenkelse og verdighet}

På spørsmålet om norske elevers verdighet kan krenkes på grunn av religionsforskjeller (jf. den innledende problemstillingen), må svaret bli ja. Vi kan ikke si noe særlig om hvordan og hvor ofte det skjer, men i begge de to kasusene vi har sett på, behandles annerledes troende med Schabers ord «as if they had no normative authority over themselves and over how they are treated». Dette er tydeligst i filmen der buddhismen fremstilles unyansert og tendensiøst, uten at programlederen gir fra seg noe av sin definisjonsmakt. Informantene krenkes ikke fordi deres religion blir utsatt for kritikk. De krenkes heller ikke fordi kritikken er dårlig fundamentert rent faglig. Slik vil det ofte være, og elever og lærere kan oppøve evnen til å være uenige uten dermed å avvikle fellesskapet. Ifølge den forståelsen av menneskeverd som ligger til grunn for denne artikkelen, krenkes informantene fordi de frakjennes definisjonsmakt på det religiøse feltet og dømmekraft på det moralske feltet. Krenkelse i form av å bli tillagt ulik status ser vi kanskje tydeligst i det siste kasuset, der grunnskolelæreren er skeptisk til å la «Jehovas vitner få bruke skolen som talerstol».

Når en elev ikke kan feire fødselsdager, kan læreren ved hjelp av noen få grep gjøre det til et problem - for eksempel ved å underkommunisere mangfold og konsekvensene av mangfold. Læreren har rett i at eleven kan «føle seg (...) utenfor» dersom alt fortsetter som før. Selv om det høres ut som en klisjé, kan læreren i stedet se det økende mangfoldet som en ressurs. Hun kan undersøke mangfoldet sammen med elevene, og bidra til at hver enkelt elev blir nysgjerrig på andres bakgrunn og stolt av sin egen enten eleven vil si noe om den eller ikke. Da blir sjansen større for at den enkelte får oppleve en «upwards equalization of rank» (Waldron, 2012).

\section{Avsluttende om to måter å fremme humanisme på}

Skolen er så mye, blant annet et ensrettende system som kan gjøre det vanskelig for elever som har andre mål enn skolens mål, og som derfor går i en annen retning enn flertallet. Skolens mål er dennesidige, mens religionenes mål i stor grad er hinsidige. I de to kasusene jeg har presentert i 
denne artikkelen, er det imidlertid ikke skolen som system, men enkeltloerere som behandler elever på måter som krenker deres verdighet: den ene ved å vise en film der en journalist krenker sine informanter for åpent kamera, den andre ved å unnlate å endre en diskriminerende praksis

Både Are og praksislæreren er tydelige på hvilke verdier de selv står for. De synes i hovedsak å godta de verdiene som er nedfelt i opplæringsloven, og de gjør som lærebøkene når de i praksis er mer opptatt av likestilling som uttrykk for likeverd enn av likeverd som sådan. De synes å oppleve «de andre», altså de som ikke har et humanistisk grunnsyn, og de religionene de tilhører, som så problematiske at de bør bekjempes fremfor å inviteres inn i dialog. Slik legitimeres en humanistisk motivert krenkelse.

Vi kan skjelne mellom to måter å markere humanistiske idealer og verdier på. På den ene siden finner vi en målorientert eller teleologisk humanisme som kritiserer og bekjemper ikke-humanistiske ordninger og institusjoner og holder frem humanistiske alternativer. Den kan forsøksvis karakteriseres som en misjonerende, konfronterende eller autoritær humanisme. På den andre siden finner vi en mer deontologisk, dialogisk eller lyttende humanisme med større oppmerksomhet på humanistiske verdier som styrende for hvordan en arbeider eller kjemper for en utvikling i humanistisk retning. Det er i og for seg ingen motsetning mellom disse to måtene å fremme humanisme på, men det kan fort bli det, slik vi har sett ovenfor.

Om vi ser nærmere på de tre som representerer moderne humanisme i denne artikkelen, står lærerstudenten i kasus 2 i hovedsak for en dialogisk humanisme, mens praksislæreren i samme kasus og Are i kasus 1 tar avgjørelser på vegne av andre og utøver en autoritær form for humanisme. Særlig Are ser likestilling som et uttrykk for likeverd, ja kanskje som viktigere enn likeverd. Det er videre interessant at studenten er den eneste i dette materialet som etterspør fagkunnskap og vil konsultere lover og forskrifter. Til sist kan det nevnes at alle tre tenderer mot en tydelig «annengjøring» av både buddhister og Jehovas vitner. Men mens studenten ser alle involverte som ansvarlige individer, tenderer Are og praksislæreren mot å se de to jentene og Jehovas vitne-eleven som ofre. De er ført bak lyset av sin egen religion, sin familie og sine (vei)ledere. 
En TV-personlighet og en lærer har begge stor makt og blir lyttet til på sine respektive felt. Når de vet så mye bedre enn dem det gjelder hva som er riktig og galt for dem, utsetter de sine ofre for en umyndiggjøring som i kasus 1 er ekstra ydmykende fordi den kringkastes til hele skole-Norge. Slike «acts of degradation and humiliation are paradigm violations of dignity», ifølge Schaber (2014).

\section{Forfatteromtale}

Geir Winje arbeider som dosent ved Universitetet i Sørøst-Norge, hovedsakelig ved lærerutdanningene. Winje har publisert flere bøker og artikler, som oftest med fokus på religionsdidaktikk, religion og modernitet eller religion og kunst.

\section{Referanser}

Grønntun, J. M. (2017). «På tro og Are» i religionsundervisninga. Ein kvalitativ studie av refleksjonar elevar har til ein dokumentarserie i religion og etikk.

Masteroppgave i religions- og etikkdidaktikk, Universitetet i Oslo (www.duo.uio. no/handle/10852/58184? show=full - sist lest 24.10.2019).

Holth, G. \& Deschington, H. (2006). Horisonter 8. KRL for ungdomstrinnet. Oslo: Gyldendal.

Jacobsen, K. A. (200o). Buddhismen. Oslo: Pax.

Jacobsen, K. A. (2009). Hva er hinduisme. Oslo: Universitetsforlaget.

Knudsen, S. V. (2010). Poststrukturalistiske tilgange. I S. V. Knudsen \&

B. Aamotsbakken, (Red.), Teoretiske tilnoerminger til pedagogiske tekster.

Kristiansand: Høyskoleforlaget.

Laursen, M. H. (2010-2017). Abduktiv.dk (www.abduktiv.dk - lest 27.2.2019)

Lybæk, L. (2017). Religioner og menneskerettigheter. I G. Winje (Red.), Grunnleggende felles verdier? Menneskerettigheter og religionspluralisme i skolen. Oslo: Cappelen Damm Akademisk.

Ringnes, H. K. \& Sødal, H. K. (Red.) (2007). Jehovas vitner. En flerfaglig studie. Oslo: Universitetsforlaget.

Rosen, M. (2012). Dignity. Its History and Meaning. New York: Harvard University Press.

Said, E. W. [1978] (2004). Orientalismen: vestlige oppfatninger av Orienten. Oslo: Cappelen. 
Schaber, P. (2014). Human Rights and Human Dignity. A Reply to Doris Schroeder. Ethic Theory and Moral Practice. An International Forum nr. 17.

Valen-Sendstad, Å. (2017). Menneskerettighetene og skolen. I G. Winje (Red.), Grunnleggende felles verdier? Menneskerettigheter og religionspluralisme i skolen. Oslo: Cappelen Damm Akademisk.

Waldron, J. (2012). Dignity, Rank, and Rights. Oxford: Oxford University Press.

Wiik, P. \& Waale, R. B. (2015). KRL-boka 8-10. Oslo: Cappelen Damm.

Wilkinson, S. \& Kitzinger, C. (Red.) (1996): Representing the Other: a Feminism and Psychology Reader. London: Sage.

Winje, G. (2011). Når «de andre» rykker nærmere. Om 1900-tallets lærebøker i kristendomskunnskap. I D. Skjelbred \& B. Aamotsbakken, (Red.), Norsk loerebokhistorie III - en kultur- og danningshistorie. Oslo: Novus. 


\title{
KAPITTEL 5
}

\section{Seksuell trakassering, verdighet og SKAM}

\author{
Rønnaug Sørensen \\ Universitetet i Sørøst-Norge
}

\begin{abstract}
In this chapter, I discuss the causes and consequences of masculine domination in sexuality. My main theoretical inspiration is Bourdieu's theory of masculine domination and his key concept symbolic violence. The Norwegian TV-series SKAM is my empirical case. I will trace the historical roots of masculine domination, and discuss how this puts limits on female sexuality, integrity and dignity.

By identifying "the elephant in the room", masculine domination, Bourdieu claims that we can see sexual harassment as a type of social control of women and gay people, using shame as the key control mechanism. I will analyse the reproduction of masculine dominance and symbolic violence through language; by the use of words like "whore" and "homo", and through masculine stigmatizations of "good" and "bad" girls.

The TV-series SKAM has had a considerable impact on the how Norwegians talk about sexual harassment, homophobia and other religions. SKAM shows how the youth can strengthen their self-esteem by dismantling the taboos and making them aware of social control mechanisms. In this chapter, I am addressing teachers to use SKAM to discuss sexual harassment, and to continuing dismantling cultural taboos.
\end{abstract}

Keywords: Symbolic violence, sexual harassment, dignity, SKAM, \#metoo

Dette kapitlet handler om seksuell trakassering og verdighet blant ungdom. ${ }^{1}$ Unge mennesker er seksuelt sårbare, og seksuell trakassering truer derfor individets verdighet på en svært intim måte. På samme måte som det tradisjonelle begrepet $a r e$ knytter den moderne forestillingen

1 En særlig takk til professor i sosiologi Rune Åkvik Nilsen for viktige innspill, støtte og tålmodighet $\mathrm{i}$ arbeidet med denne artikkelen.

Sitering av denne artikkelen: Sørensen, R. (2019). Seksuell trakassering, verdighet og SKAM. I Å. Valen-Sendstad \& I. R. Christensen (Red.), Menneskeverd - en utfordring for skole og samfunn (Kap. 5 , s. 119-139). Oslo: Cappelen Damm Akademisk. https://doi.org/10.23865/noasp.9o.ch5.

Lisens: CC BY-NC 4.o. 
om verdighet seg til individets status eller sosiale posisjon (Berger, 1970). Ringeakt i form av nedverdigelse eller krenkelse truer individets verdighet; sosial anerkjennelse, derimot, øker verdigheten. Verdighet er derfor relasjonell: Den tapes eller vinnes gjennom sosiale anerkjennelsesprosesser (Honneth, 2008). Med seksuell trakassering på grunn av kjønn menes handlinger, unnlatelser eller ytringer som virker eller har til formål å virke krenkende, skremmende, fiendtlige, nedverdigende eller ydmykende. Seksuell trakassering innebærer uønsket seksuell oppmerksomhet som er plagsom for den oppmerksomheten rammer. Seksuell trakassering er forbudt ved lov siden 1992. I loven er verdighet nevnt eksplisitt. Bakgrunnen for dette er en internasjonal innføring av begrepet dignity, hentet fra menneskerettighetene. Dette er en formell anerkjennelse av at seksuell trakassering truer verdigheten.

På tross av denne formelle anerkjennelsen har loven dessverre ikke fungert etter intensjonen: Den klarer ikke å beskytte kvinners verdighet. \#metoo-kampanjen høsten 2017 demonstrerte dette med all tydelighet. Kampanjen viste at det er stor avstand mellom idealer og realiteter. I spørreundersøkelser kommer det fram at et stort antall kvinner har blitt utsatt for seksuell trakassering. Imidlertid er det kun et fătall av disse sakene som når fram til rettsvesenet. I tillegg har trakassering blitt bagatellisert i det offentlige ordskiftet, noe som har medført at svært få har våget å si ifra. Twitterkampanjen \#jeg har opplevd (Fett, nr. 2, 2015) var et forsøk på å synliggjøre at seksuell trakassering har vært et omfattende problem. I løpet av to døgn kom det hele 13 ooo innlegg (Sveen, 2016). I en fersk undersøkelse kom det fram at $\mathbf{2 2} \%$ av jentene i videregående skole har blitt befølt seksuelt mot sin vilje (Bakken, 2017).

Seksuell trakassering kan forstås ut fra tre perspektiver: (1) Det individuelle - som en personlig krenkelse av individets egne grenser; dernest strukturelt som brudd på normer, enten (2) i arbeidslivet eller (3) knyttet til kjønnede begreper for ære eller verdighet. Samfunnet har forsøkt å ta tak i de to første punktene, gjennom ny lovgivning. Min hypotese er at lite har endret seg med hensyn til det tredje perspektivet: Seksuelle normer forankret i kultur og religion påfører jenter og homofile gutter skamfølelse og redsel for tap av verdighet, slik at de ikke tør å si ifra om seksuelle krenkelser. 
Uformelle seksuelle normer eksisterer parallelt med lovverket og står i motsetning til dette. Denne motsetningen skaper paradokser som særlig unge må forholde seg til. Ungdomsserien SKAM gir en fortettet dramatisering av disse paradoksene. SKAM vil derfor være min empiriske case. Jeg vil primært fokusere på jentene i serien, men vil også i noen grad analysere de homofile guttene. Ungdom er avhengig av anerkjennelse og tilhørighet utenfor familien. I SKAM er derfor vennskap et sentralt tema, vevet sammen med utfordringene knyttet til utprøvingen av seksualitet og seksuell trakassering som utstøtingsmekanisme. Jeg vil særlig fokusere på de sosiale strukturene som fører til individenes opplevelse av skam og tap av verdighet. Disse strukturene har svært lange historiske røtter; av den grunn vil jeg betegne dem som kulturelle dypstrukturer. Disse dypstrukturene er ikke nødvendigvis erkjente, de erfares mer eller mindre ubevisst som doxa: noe vi oppfatter som naturlig, eller tar for gitt (Bourdieu, 2000). Disse langvarige strukturene er vanskelig å forandre, de lar seg ikke lett forhandle bort. Likevel vil jeg vise hvordan ungdom kan utfordre strukturene, og forsøke å overskride dem.

I dette kapitlet vil jeg først gi en kort historisk oversikt over de kulturelle dypstrukturene seksualiteten er vevet inn i. Dernest analyseres moderne forestillinger om seksualitet, og jeg utdyper de sentrale teoretiske perspektivene jeg vil benytte. Min teoretiske forståelse er inspirert av den franske sosiologen Pierre Bourdieus (200o) teori om maskulin dominans og hans nøkkelbegrep symbolsk vold. I den siste delen av kapitlet vil jeg skissere min metodiske tilnærming, og analysere SKAM empirisk. Flere spørsmål drøftes: Hvilke grenser finnes for jenters seksuelle frihet? Når er den seksuelle integriteten og verdigheten i fare? I avslutningen løfter jeg fram et normativt perspektiv: Hva kan analysen av SKAM bidra med i arbeidet med å forebygge seksuell trakassering? Hva kan lærere lære av seriens tematisering av seksuell trakassering, verdighet og skam blant ungdom?

\section{Hvor kommer de seksuelle dypstrukturene fra?}

Kjønnede æresbegreper betyr at menn og kvinner produserer ære og status på ulike måter. Flere antropologer hevder at dette skillet er særlig tydelig 
når det gjelder seksualitet (Melhus, 2001; Bourdieu, 2000). I de abrahamittiske religionene (jødedom, kristendom, islam) ses kvinners seksuelle ære som en verdi som skal forvaltes. «Kvinnens moral ligger i hennes natur, $i$ hennes kropp eller forholdet hun har til sin kropp. En moralsk kvinne gjenkjennes ved måten hun forholder seg til sin kropp på» (Haug, 1990, s. 14).

Har denne æresdistinksjonen sin rot i noe disse religionene har felles? Eller kanskje vi til og med må tilbake til tiden før de abrahamittiske religionene oppsto? Dette hevder både antropologen Unni Wikan (2008) og historikeren Amanda Forman (2016). ${ }^{2}$ Kvinner og menn var mer likestilte på sumernes tid på 300o-tallet f.kr. Deretter gikk kvinnene gradvis inn i en rolle som menns eiendom. Samfunnene ble patriarkalske, tydelig mannstyrte. Begrensninger i kvinners handlingsfrihet ble først introdusert hos babylonerne fra 2000 f.kr. Kvinner ble fratatt rettigheter som likeverdige i det offentlige rom, og kvinners seksualitet ble skambelagt. Assyrerne etterfulgte babylonerne, og de begrenset kvinners rettigheter ytterligere. I likhet med menn ble kvinner inndelt i ulike klasser. De laveste klassene, slik som slavene, var nakne; skjøgene som var rangert over dem, hadde gjennomsiktige klær, eller veldig lite klær. Kanskje uttrykket «lettkledd» kommer herfra? Imidlertid var kvinner i høyerestående klasser svært tildekket. Dette ble også adoptert av grekerne i antikken. Bystaten Sparta innførte det første heldekkende plagget for kvinner. Burkaen kommer derfor herfra, ikke fra muslimene, slik vi er tilbøyelig til å tro. I Sparta ble tildekkingen sett på som høyverdig, og var et tegn på høy rang. Som et utgangspunkt for å analysere betydningen av tildekkingen i våre dager, kan derfor tildekking tolkes som et tvetydig fenomen: både ærbart og kvinneundertrykkende på en gang. Imidlertid har alle kulturer en norm for klesdrakt som er mer eller mindre skambelagt.

Patriarkatet førte med seg en kulturell forestilling om at seksuelle krenkelser av kvinner ble sett på som en mangel på respekt for andre menns eiendom. Flere muslimske land i Midtøsten har beholdt denne forståelsen av ære. Menn bruker derfor mye tid på å overvåke sine kvinner, det vil si passe på sin eiendom. Hvis eiendommen krenkes, ses det som et tap av mannens ære.

2 http://www.ascentofwoman.com/ 
Den kulturelle rangeringen av kvinners ærbarhet lever videre i vår tid. Inspirert av den franske sosiologen Pierre Bourdieu (2000) er min påstand at vi finner spor av denne rangeringen i vår sivilisasjons doxa, det vi si som en del av det vi tar for gitt, noe vi oppfatter som naturlig, eller selvfølgelig - og som vi derfor heller ikke tematiserer eller settes spørsmål ved. Rangeringen ble adoptert av de abrahamittiske religionene, og har blitt ført videre i disse religionenes kulturelle praksis gjennom religionsseksuelle reguleringer (Endsjø, 2009). I moderne tid ble de tradisjonelle forestillingene om kvinners ærbarhet sammenvevet og supplert med nye ideer om kvinners anstendighet og verdighet.

\section{Moderne forestillinger om kvinnelig anstendighet og verdighet}

Sigmund Freud har hatt stor innflytelse på forståelsen av mennesket i moderne, vestlig kultur. Bourdieu (2000, s. 123) hevder at Freud bygget sin teori rundt den samme inndelingen mellom menn og kvinner som i de gamle patriarkalske forestillingene. Dette bidro til at hans driftsteori ikke var noe brudd, men snarere en omskrivning av dominanskulturen. Freud la stor vekt på seksualitet, og oppfattet mennesker som primært styrt av medfødte drifter. Driftene er potensielt ustyrlige og må derfor kontrolleres. Uten kontroll, ingen sivilisert sosial orden, og heller ikke noe moralsk anstendig liv. Kravet om anstendighet, kontroll av seksualiteten, ble særlig rettet mot kvinnene i tråd med den doxiske orden. Mannlig dominans, derimot, blir inkorporert i psykoanalysen: Mannens dyriske drift «overlever» her som en forestilling om en drift som er vanskeligere å temme enn kvinnens. Og ved et punkt er den ustoppelig. Kroppen overstyrer fornuften: Menn vet ikke lenger hva de gjør, og fratas dermed også ansvaret for sine handlinger. Derfor må kvinner forstå at etter dette punktet er det de som har ansvaret for eventuelle krenkelser (Norberg, 2013).

I flere voldtektssaker ser vi spor av denne forståelsen av menns seksualitet, noe som bidrar til redusert straffeutmåling og frifinnelser. Det bekymringsfulle er at lovverket på denne måten ikke fungerer etter hensikten. Domstolene svikter som en samfunnsinstitusjon som skal 
beskytte kvinners verdighet mot krenkelser. Rettsapparatet bytter ut æresbegreper med begreper som seksuell integritet. Voldtas en prostituert vil overgriperen eksempelvis få strafferabatt fordi offeret mangler eller har lite seksuell integritet.

I Likestillingsombudets FN-rapport, januar 2017, sies det for eksempel:

Tidligere har det vært en utfordring med juryordningen fordi juryen ikke har hatt plikt til å begrunne sin dom. Samtidig kan holdninger, særlig hos lekdommere, om at kvinner selv kan klandres i forbindelse med voldtekt, eller manglende kunnskap om voldtekt hos lekdommere, svekke kvinners rettssikkerhet i voldtektssaker. ${ }^{3}$

I rapporten hevdes det videre at rettssystemet heller ikke er egnet til å beskytte mot denne formen for lovbrudd:

Domstolene er en for høy terskel for de som utsettes. Det antas at mellom 800016000 kvinner voldtas hvert år. Relativt få anmelder voldtekt; tallet for 2015 er 1367 anmeldelser. Videre ender svært få anmeldelser med dom. Politidirektoratets egen gjennomgang av etterforskningen av voldtektssaker viser at 39 prosent av sakene var etterforsket med «lav kvalitet og effektivitet» eller «meget lav kvalitet og effektivitet». Særlig er utilstrekkelig innhenting av tekniske bevis et hinder for domfellelse. ${ }^{4}$

Det norske samfunn er preget av den kristne kulturarven. Av den grunn har samfunnet også bevart mye av den kulturelle doxa med hensyn til kvinners ære og verdighet. Det kan se ut til at kvinner er overlatt til seg selv for å forvalte sin seksuelle integritet, uten særlig hjelp fra lovgivningen. Det er kvinnene som eier sin egen kropp, men ikke nødvendigvis sin egen seksualitet. Kroppen har blitt kvinners egen, gjennom menneskerettighetene, og som rettssubjekter, men hennes seksualitet og forvaltningen av seksualiteten er fremdeles et moralsk og kulturelt anliggende. Hun må vise til en seksuell integritet som er verdig.

Med andre ord eksisterer den doble seksuelle standarden fortsatt. Det innebærer at gutters og jenters seksuelle praksis vurderes ulikt. Et eksempel

3 http://www.aftenposten.no/norge/25-aringen-tilsto-og-ble-domt-for-voldtekt-----likevelmener-retten-han-hadde-et-berettiget-hap-om-sex-608063b.html

4 http://www.ldo.no/globalassets/brosjyrer-handboker-rapporter/rapporter_analyser/rapporter_ diverse/cedaw2017.pdf 
på dette er følgende: Flere jenter hevdet på Debatten i NRK (våren 2016) at jenter i motsetning til gutter blir sett på som horer hvis de hadde samleie med flere gutter i løpet av russetiden. Jenter kunne bli stemplet som horer, mens gutter ikke ble stemplet på samme måten, tvert imot: Guttene fikk høyere status jo flere jenter de hadde sex med. Guttene tillates å være skamløse, jentene blir påført skyld og skam (Ås, 1979). Jentene kan med andre ord ikke være for seksuelt aktive uten å bli stemplet som ikke-respektable. Dette er ikke noe det kan forhandles om: Den doble seksuelle standarden hviler fortsatt på et bunnsolid doxisk fundament. Mer enn det: Jenta blir til og med forventet å stå opp mot gutten. Jenta må begrense tilgangen til sin egen seksualitet for ikke å havne i en skamfull og uverdig posisjon, hvor hun får skylden for at de begge lot seg rive med av det seksuelle begjæret.

\section{Den maskuline dominans og doxiske erupsjoner}

Kvinners utseende blir av Bourdieu (2000) definert som erotisk kapital, en kilde til status. Her stilles imidlertid kvinnene ovenfor en vanskelig balansegang. Skal den erotiske kapitalen fungere som middel til sosial mobilitet må den forvaltes på den riktige måten. Kvinnene må framstå som respektable. Her er det en tydelig klassedimensjon. Den hegemoniske middelklassen betrakter arbeiderklassens kultur som vulgær. Dette rammer kvinner fra arbeiderklassen som i særlig grad blir oppfattet som seksuelt vulgære, ifølge Beverly Skeggs (1999). Sett fra mannens perspektiv betyr dette at det er en type løsslupne kvinner du gjerne har sex med, men du gifter deg ikke med noen av dem, men med én respektabel kvinne. Hos Bourdieu kan en kapitalform bli opphøyd til symbolsk, hvis den blir anerkjent, og dermed oppfattet som legitim. Hvis en kvinnes erotiske kapital skal bli oppfattet som symbolsk, må hun derfor framstå som en respektabel kvinne. En slik kvinne vil også være en del av den symbolske kapitalen til sin mann, den respektable kvinnens erotiske kapital løfter hans sosiale status: Han kan triumferende presentere henne som sin trophy wife.

Sosialiseringen av barn er kjønnsspesifikk fra første stund. Det er imidlertid først i ungdomstiden at seksualiteten i særlig grad preger kjønnsrelasjonene. Bourdieu (2000) hevder også at det er i ungdomstiden 
dominanskulturens oppfatninger om kjønn blir tydelig. Seksualiteten aktualiserer kjønnsforskjellene og synliggjør tabuområder for hvordan man «gjør» kjønn. Dette vil jeg metaforisk kalle for doxiske erupsjoner. ${ }^{5}$ Det innebærer at dominanskulturens dypereliggende oppfatninger kommer til syne i ungdoms samhandling. Eksempelvis trakasseres både jenter og gutter allerede fra elleveårsalderen med ord som hore og homo, med andre ord mange år før de fleste har en seksuell praksis. Den svenske forfatteren Manne Forssberg (2005, s. 64) kaller dette for «hore- og homosystemet». Hore og homo erstatter andre ord som dumma, tjukka, dusten. Ordene viser både til det respektable og det heteroseksuelle som norm, og bruken av ordene vitner om at normene er en del av doxa allerede i prepuberteten. Ordene fungerer som et «frampek» mot framtidig praksis. Hvis du eksempelvis blir interessert i noen av det samme kjønnet som deg selv, vil du kjenne at det er noe skamfullt i det du føler. Likeledes er det for jenter som etter sin andre partner tenker: «Er jeg hore nå?» Ordene vitner om sosial kontroll, samtidig som de oppleves som seksuell trakassering (Helseth, 2006, 2010). Kvinners og homofiles frihet begrenses gjennom en uformell sosial kontroll av seksualitetens tabuer. Verdighet som verdi undergraves av praksis.

Den maskuline dominans som doxa betyr at menn blir definert som det dominerende kjønn og forstår seg selv i lyset av dette. I tillegg innebærer det at kvinner samtidig ser på seg selv som det dominerte kjønn. Bourdieu (2000) kaller dette for «det androsentriske ubevisste», et ubevisst kognitivt skjema hvor begge kjønn anerkjenner dominansforholdet. Mannens forrang forsterkes gjennom at dominansforholdet får en objektiv og universell karakter i de sosiale strukturene. Dette gir en doxisk konsensus om meningen med sosiale praksiser, eksempelvis arbeidsdelingen mellom kjønnene og forståelsen av seksuelle overgrep. Brudd på dominansforholdet medfører at individene påføres skam ved at omgivelsene viser uttrykk for miskjennelse (tap av posisjon, ære, verdighet). Dette kaller Bourdieu for symbolsk vold (200o). Den som påføres skam, føler skam fordi de burde vite bedre. Den symbolske volden uttrykkes gjennom diagnoser, 
stigma, ryktespredning - sanksjoner fra fellesskapet på individenes brudd på normer. SKAM-serien er full av denne typen symbolsk vold.

\section{Metodiske bemerkninger om SKAM}

Manusforfatteren Julie Andem ${ }^{6}$ sier dette om forarbeidet til serien:

Vi gjorde både speedintervjuer med hele klasser ... og dybdeintervjuer: tre timer lange intervjuer med forskjellige ungdommer fra ulike deler av landet.... Vi vet hvem de er, og vi forstår dem fordi vi kjenner kulturen de har vokst opp i. Det er helt avgjørende for SKAM.

Likevel klarte serien å nå langt utover den norske konteksten. Min påstand er at dette er fordi SKAM gir en fortettet dramatisering av de seksuelle dypstrukturene jeg har redegjort for foran. Jeg har påvist at disse strukturene har lange historiske røtter, og de finnes i mange andre samfunn i tillegg til det norske. SKAM utfordrer de seksuelle dypstrukturene. Dette skaper nerven i serien: «Serien speiler og bearbeider strukturer som seerne kan kjenne seg igjen i og har erfaringer med fra egne liv»(Sørensen, 2018, s. 136). Fokuset på dypstrukturer har metodiske implikasjoner for analysen av SKAM. Jeg fokuserer på dypstrukturer som ikke nødvendigvis er erkjent av verken serieskaperne eller seriens informanter. Dette betyr imidlertid ikke at jeg kan overse informantenes egen forståelse, jeg ønsker nettopp å få fram spenningene mellom strukturene og aktørenes opplevelser og følelser (Tjora, 2017). Analysen krever derfor en dobbel hermeneutikk (Giddens, 1976). Den doble hermeneutikken bygger på et skille mellom erfaringsnære og erfaringsferne begreper (Nilsen, 2005, s. 6). Det innebærer at forskeren først må ta utgangspunkt i de erfaringsnoere begrepene aktørene (karakterene i serien) forstår seg selv og sine handlinger ut fra. Dernest må forskeren fortolke materialet videre i lys av erfaringsfjerne, vitenskapelige begreper som går utover aktørenes egen subjektive forståelse av sin virkelighet, slik den framkommer i dialogene i serien. Symbolsk vold er eksempelvis et erfaringsfjernt nøkkelbegrep i min analyse, i dette tilfellet et begrep for de seksuelle

6 http://rushprint.no/2016/o4/nerven-i-skam-skal-vaere-sterk-og-relevant/ 
dypstrukturene seksualiteten er vevet inn. Samtidig er det et hovedpoeng å vise at mennesker ikke er fullstendig styrt av sosiale strukturer. I min analyse av SKAM vil jeg drøfte hvordan sentrale aktører prøver å utfordre og overskride den symbolske volden. Analysen av SKAM vil illustrere hvordan den symbolske volden uttrykkes gjennom ulike krenkelser ungdommene utsettes for, og utsetter hverandre for.

Analysen bygger på serien som helhet. Likevel har det vært nødvendig å gjøre noen valg. Jeg vil særlig fokusere på episoder, scener og dialoger der den symbolske volden kommer til uttrykk. I tillegg vil jeg spesifikt analysere dialoger som tematisk synliggjør de seksuelle dypstrukturene: sosial kontroll, seksuell trakassering, seksuelle/kjønnede krenkelser. Samtidig vil jeg også være opptatt av de demokratiserende refleksjonene serien inviterer til (Dahl \& Lindter, 2018). Her ser jeg etter normbrudd, motmakt, og alternative verdighetsprosjekter.

\section{Jentefellesskapet i SKAM}

I vår kultur er det skamfullt ikke å ha et sosialt nettverk. Venner er derfor en form for sosial kapital, hevder Bourdieu (Wilken, 2008). Samfunnsforskere peker på at vennskapsrelasjoner har fått økt betydning i forhold til familierelasjoner (Frønes, 2013). Dette gjelder ikke minst i ungdomskulturen. I Ungdata-undersøkelsen fra 2017 sier 9 av 10 at de har minst en nær og fortrolig venn (Bakken, 2017). Det vanligste er å holde sammen i en vennegjeng. Det som gir mest status i vennemiljøet, er å være til å stole på. Med venner snakker ungdommer om temaer de ikke tar opp med foreldrene. Vennskap representerer en helt særegen, selvvalgt nærhet.

I tråd med dette står vennskap svært sentralt i SKAM. I løpet av serien utvikler de kvinnelige hovedkarakterene et sterkt jentefellesskap (Sørensen, 2018). Serien viser at ungdom som ikke hører til et fellesskap er lettere å utnytte. For å få «cred», øke sin sosiale kapital, blir karakterene i serien lurt til å gjøre ting som kan oppleves som nedverdigende og krenkende. Eva er hovedpersonen i sesong 1 i SKAM. Hun bryter med normen om at du ikke

7 Et eksempel på dette fra Norge i nyere tid, er jenter i første klasse på videregående skole som suger tredjeklassegutter i fadderuka for å bli populære. Ingen av jentene som ble med på dette, økte statusen sin. Snarere ble de stemplet som horer. https://www.buyandread.com/pub/ 
skal stjele din venns kjoreste. Hun blir som straff betegnet som en slut og utestengt fra fellesskapet med sine gamle venner.

\section{Hore/slut - hvordan opprettholde sin seksuelle integritet og verdighet?}

Hvilke grenser finnes for jenters seksuelle frihet? Når er den seksuelle integriteten og verdigheten i fare? «Seksualitet kan byttes mot cred», sier den muslimske Sana (sesong 1, episode 3). «Vi kan ikke bytte seksualiteten vår mot cred», protesterer Noora. «Jo», sier Sana. «Norske jenter bytter sex mot penger og popularitet og bekreftelse hver dag. Det er ikke sikkert du er enig med meg. Men det er ikke nytt for deg. Det er din kultur. Og hvis du synes den er så gæærnt så synes jeg du skal prøve å endre på den i stedet for å kritisere.» Her slås tonen an: Seksualitet kan omsettes i sosial kapital, men det er avgjørende at seksualiteten brukes på den rette måten. Det gjelder med andre ord å lære seg de seksuelle spillereglene, noe alle sesongene i SKAM tar opp.

I den første sesongen blir begrepet hore/slut brukt på fire forskjellige måter avhengig av relasjonen til den som sier det, og konteksten. Slut blir for det første brukt på handlinger som er brudd på en kontrakt: utroskap, eller at en ungdom, som Eva, «stjeler en annen jentes kjæreste». Svartelistingen følges opp med trusler om vold, om å bli klippet av håret, kastet i vannet, trusselbrev med mensblod, med mer. Dette utføres i hovedsak av jenter. Slut kan for det andre knyttes til utseende: Du ser ut som en hore (lettkledd, for mye sminke). Slut kan brukes på denne måten som hersketeknikk mot jenter av både jenter og gutter. Implikasjonen er: Du ser ut som en slut, jeg vil ikke være verken venn eller kjæreste med deg. Slut kan for det tredje fungere som tulleord mellom jentevenner: Go for it, din lille slut - som episode 4 (sesong 1) heter. Lignende uttrykk er «kom hit da, hora mi», «du er så slutty, altså», i betydningen nå beveger vi oss litt på kanten og framstår ikke som snerpete. Til sist brukes slutty som benevnelse på seg selv overfor gutter for å signalisere at «jeg vil gjerne hooke»

Schibsted-publisher_schibsted/VG-verdensgang/VG\%2oHelg-verdensgang_helg/2016-08-2020160820/VG\%2oHelg\%2020.08.16.htm 
eller er kåt, oftest uttalt av jenter som står utenfor, eller selv definerer seg som utenfor statushierarkiet (eksempelvis Jente-Chris).

«Alle» «hooker», det vil si å kline, fingre eller suge og slikke. Vi får vite at å hooke ikke er sex, og at det ikke kreves en relasjon for å gjøre dette, men at det kan føre til mer. Likevel fører det til sanksjoner gjennom ryktespredning hvis man hooker med «feil» person - at vedkommende enten har kjæreste eller lav status. Uavhengig av kjønn er statusen til den man hooker med viktig. Tredje klasse er status. Hooking blir brukt i bytte mot noe annet eller en forventet gjenytelse, for eksempel rulleplasser på en russebuss. Også her er det kjønnsspesifikke normer involvert. Gutter kan ikke kline med hverandre, det kan jenter. Blant guttene er det uakseptabelt å hooke med andres damer. Ifølge Endsjø (2009) er dette et av de eldste religionsseksuelle tabuene.

\section{Symbolsk vold: synliggjøring, motstand og overskridelser}

Jenter bidrar ofte til å styrke den maskuline dominansens forståelse av ærbare og ikke ærbare jenter, de blir hverandres voktere. I SKAM er det særlig Noora som synliggjør og utfordrer denne typen symbolsk vold. Noora sier til Vilde (sesong 1, episode 8): «Hvordan kan du som kaller deg feminist, kalle andre jenter for slutty eller hore?! Det synes jeg du skal slutte med.» Poenget til Noora er at selv om gutter snakker nedsettende om jenter, behøver ikke jenter å gjøre det samme, det er ikke feminisme. Å ta tilbake med samme mynt mener hun i tillegg er uverdig (sesong 1, episode 6). Ved å tydeliggjøre og synliggjøre begrepets undertrykkende funksjon sier hun noe om ansvaret for ikke å bidra til å nedverdige andre. Gutter blir ikke kalt for horer, og blir heller ikke sanksjonert kollektivt på samme måte. Noora peker på den doble standarden. Til det svarer Vilde lakonisk: «Slik er verden.» Hennes korte kommentar kan tolkes som avmakt, men også som en (gryende) bevissthet om den symbolske volden.

Vildes økte bevissthet om den symbolske volden kommer sterkt til uttrykk i en annen episode i sesong 1. Vilde har tidligere ligget med William. Han har høyest status og angivelig rett tilå «pule rundt». William blir derfor også omtalt som en «øøk boy». Inspirert av Noora forsøker 
Vilde å gi William en klar beskjed om at hun er ikke et levende trofé han kan smykke seg med. Han parerer angrepet med «Hva heter du? Du er jo ikke noe trofé, det er du ikke fin nok til». Williams verbale brutalitet mot Vilde er et sterkt uttrykk for maskulin dominans og symbolsk vold: Han ser det som sin selvfølgelige rett å kunne ydmyke og degradere Vildes verdi som kvinne. Noora blir imidlertid sterkt provosert av dette. Hun gir William en kraftfull reprimande om hans mangel på medmenneskelighet og antyder at hans oppførsel skyldes mangel på kjærlighet i barndommen. Det ikke å behandle jenter med respekt fører slett ikke til beundring fra alle, sier hun, og avslutter irettesettelsen med følgende kraftsalve: «Slutt å gå rundt som en jævla klisje». Nooras modige oppgjør mot den symbolske volden vekker paradoksalt nok Williams interesse for henne. Mye av sesong 2 handler derfor om at William ønsker å vise Noora at han ikke er en «føkk boy», at han har en evne til å ta et oppgjør med den maskuline dominansen.

I sesong 2 er det også fokus på hvor sårbare ungdommer er for slutshaming gjennom sosiale medier. I episode 9 drikker Noora alkohol på en fest, tar av seg klærne og sovner. Hun våkner opp sammen med en gutt og ei jente. Hva skjedde egentlig? Nico (broren til William) skriver følgende til Noora på tekstmelding når hun lurer på hva som skjedde kvelden før: «Du var jo skikkelig kåt og drøy og oppførte deg som ei lita hore». Han legger ved et bilde hvor Noora sover naken. Han truer med å vise dette til William, som Noora har et gryende forhold til. Noora husker ingen ting, men skammer seg likevel. Hun blir selv offer for den doble seksuelle standarden, og skammen viser at den symbolske volden er en del av hennes habitus. Dette er Bourdieus (1977) begrep for de kroppsliggjorte handlingsdisposisjonene individer erverver seg gjennom sosialiseringsprosesser. Habitus virker i stor grad på et ubevisst nivå, og viser seg her som en uvelkommen skamfølelse. På tross av lovgivning som beskytter jenter, viser serien at skamfølelsen er et hinder for at jenter tør å be om hjelp. Noora klarer imidlertid etter hvert å snakke om dette med vennene sine. Vennene tar henne med til helsevesenet for å sjekke om hun har blitt voldtatt. Det blir avkreftet. Støtten hun får, bidrar til at Noora blir klar over i hvilken grad rettsapparatet kan beskytte henne. Hun bevisstgjøres og konfronterer slut-shameren Nico i en av seriens sterkeste scener 
(sesong 2, episode 10). Hun utfordrer den symbolske volden, men orker likevel ikke å gå hele veien: Noora anmelder saken, men klarer ikke å møte i rettsalen fordi hun ønsker å legge opplevelsen bak seg. Mange kvinner bruker dette som begrunnelse for ikke å benytte rettssystemet på tross av at det skal verne dem.

\section{Homofobi og maskulin dominans}

Jeg var tidligere inne på hvordan ordene hore og homo blir brukt allerede av 10-11-åringer som skjellsord, og at ordene fungerer som et «frampek» mot noe som kulturelt ses på som mindreverdig. Gutter som er homofile, «feminiseres» og blir automatisk sett ned på som ikke fullverdige menn (Trettebergstuen \& Nylund, 2017). Sett med Bourdieus perspektiv er dette nettopp et uttrykk for den maskuline dominansens heteronormativitet: Det heteroseksuelle ses på som doxa, noe naturlig og normalt, det som gir status. Fram til 1977 ble homofili sett på som en sykdom, noe som medførte ulike kurer innen helsevesenet og håndspåleggelse av religiøse institusjoner. Vitenskapen har imidlertid påvist at homofili finnes i de fleste dyrearter. Det er derfor ikke noe grunnlag for å si at homofili er unaturlig. Skammen knyttet til homofili er derfor utelukkende en sosial konstruksjon, fortsatt virksom som doxa.

Nedvurderingen av homofile fører med seg en uvilje mot å stå fram som homofil. Gutter kan i verste fall oppleve å miste vennene sine, eller i det minste kanskje tape den posisjonen de har opparbeidet seg i guttegjengen. I SKAM blir vi introdusert for homo som skjellsord i ulike kontekster. For det første benyttes ordet som betegnelse på smakspreferanser, eksempelvis musikk (sesong 1, episode 2): «Du kan bare sånne homselåter, ass», sier Jonas til Isak. For det andre brukes homo som en grenseoppgang mellom kul og ikke kul: «Du kan sove på samme rommet som Isak», sier Jonas til Elias. Han svarer: «Skal jeg sove sammen med den homsen?». «Hvorfor kaller dere meg homse?», innvender Isak. «Du er en homse. Slapp av da - skjønner du ikke kødd eller?», sier Jonas. For det tredje kan mangel på samvær med det annet kjønn bidra til mistanke om en homofil seksuell legning. Derfor hooker Isak med jenter. Jonas, som benytter ordet homo på så mangt, reagerer når Isak diskrediterer en 
tydelig åpen homofil. «Hva er greia? Hvorfor disser du homofile?», sier han til Isak (sesong 3, episode 3). Den maskuline dominansen opprettholder en tvetydighet ved bruken av ordet homo. Dette skaper ambivalente følelser og medvirker til at mange homofile sliter med å komme ut av skapet (Trettebergstuen \& Nylund, 2017).

Isak illustrerer denne ambivalensen selv etter at han har kommet ut av skapet. «Jeg er homo, men ikke homo sånn som deg», sier Isak til Eskil som er en åpent feminin homofil mann (sesong 3, episode 5). Isak ser fremdeles den feminine mannen med et heteronormativt blikk, når han karakteriserer seg selv som annerledes enn Eskil. Dette er et eksempel på at «Gammel habitus er vond å vende» (Nilsen, 1998, s. 52). For Bourdieu er det et sentralt poeng at de kroppsliggjorte disposisjonene som utgjør habitus, er trege, vanskelige å forandre. Derfor vil endringer utløse motstand og ambivalens, slik som hos Isak.

Å forandre seksuell legning gjør at den tradisjonelle statusen blant gutta bortfaller. Det er ikke lenger noe poeng i å ha draget på damer. Denne endringen har imidlertid også noen andre konsekvenser som Isak neppe hadde forutsett. Jenter liker nemlig homogutter, nettopp fordi de er ufarlige. Isak får derfor paradoksalt nok en høyere posisjon hos høystatusjentene «Dansechicsa»: Fordi han er sammen med en annen gutt, inviterer de ham på «vors». Prisen han betaler for denne inkluderingen, er at han må bryte med den maskuline dominansens heteronormativitet.

\section{Islam og maskulin dominans}

I SKAM spiller den kristne kulturarven en sentral rolle for hvordan karakterene tenker og handler i alle sesongene:

Folk glemmer dette. Vi tror vi lever i en sekularisert verden, men det er så mange av verdiene våre som henger sammen med kristne forestillinger. Det dreier seg blant annet om synet på sex, kjønn, rus, identitet, familie, kjærlighet, trofasthet, broderskap og monogami. (Endsjø i Baarøy, 2017)

8 http://www.hf.uio.no/ikos/forskning/aktuelt/aktuelle-saker/2017/na-kan-du-studere-religion-iskam.html 
Religiøse forestillinger blir synlige og tydeliggjort når de blir konfrontert med en annen religiøs kultur. I sesong 4 av SKAM er det særlig muslimske Sana som tydeliggjør motsetningene mellom den norske majoritetskulturen og den islamske minoritetskulturen. Sanas handlingsrom som muslimsk jente tematiseres, generelt og når det gjelder seksualitet mer spesielt. Den maskuline dominansen er mer synlig i den islamske kulturen enn i den norske majoritetskulturen. Dette kommer til uttrykk i den sterke sosiale kontrollen av muslimske jenter (FETT, nr. 1-2017a og Bile, Hertz og Srour, 2017b). ${ }^{9}$ Sanas krevende utfordring er å skape seg en identitet som gjør det mulig å forene at hun er muslim, norsk og jente.

«Jeg klarer å ha norske venninner og samtidig være meg selv», sier Sana til moren (sesong 4, episode 1). Sana forsøker så godt hun kan å være en del av den norske venninnegjengen. Hun iscenesetter seg selv som ei sterk og tøff jente, med sine meningers mot. Hun er ambisiøs og har meget gode karakterer på skolen. Hun ønsker å framstå som den ultimate integrerte jenta; ei med hijab som likevel er sjef for russebussen. «Vet mamma at du er med på russebuss?», spør den eldre broren. «Nei, men du var jo med på en?», parerer hun. «Det er fordi jeg er gutt, jeg vil ikke ha hat på deg. Jeg er gutt, jeg får ikke hat. Jeg kan bare slappe av», svarer broren (sesong 4, episode 2). Her illustreres normen om at eldre brødre forvalter søstrenes ære, og derved må passe på hennes gode rykte. I tillegg er hans utsagn også indirekte et eksempel på at den doble seksuelle standarden i høyeste grad også gjelder i den muslimske kulturen. Sana bekrefter dette i en samtale med Noora: «Tro meg, du vil ikke ha en muslimsk gutt. De er sammen med norske jenter for å bruke dem. Så når de blir seriøse, når de skal ha en ordentlig dame i livet sitt, gifter de seg med en muslimsk jente og så ditcher de deg. Muslimer kan bare gifte seg med muslimer, det står i Koranen» (sesong 4, episode 2). Det Sana ikke sier, er at dette bare gjelder for kvinner, noe som skaper problemer for henne når hun blir forelsket i en som ikke er muslim. Gutten, Yosef, var tidligere muslim, men er nå sekulær, en frafallen.

At Yosef er en frafallen, skaper et stort problem i Sanas kjærlighetsliv. I tillegg blir det at Sana er muslim, brukt mot henne også i andre sammenhenger hvor hun omgås etnisk norske. Eksempelvis får hun kommentaren

9 http://fett.no/lansering-av-fett-12017-skamlos-i-oslo/ 
Sharmuta-slut på arabisk - på alle bildene hun legger ut på sosiale medier fra «rulling med russen». Fordi meldingene er på arabisk, tror hun at de kommer fra det muslimske «hijabpolitiet», men det viser seg at de er fra en av de norske guttene på bussen. Hun blir slutshamet av den norske gutten som en hevn for at hun tidligere hadde avvist å hooke med ham (sesong 2, episode 7). Sana blir med andre ord utsatt for den maskuline dominansen fra både muslimske og norske gutter. Likevel tør hun å stå opp mot den maskuline dominansen, på to måter. For det første ved å forsvare sin homofile venn Isak. I forbindelse med dette ble hun positivt overrasket over at broren og hans muslimske venner ikke var homofobe, slik hun hadde antatt. For det andre opprettholder hun kontakten med den frafalne Yosef og holder muligheten åpen for at de en gang i framtiden kan bli kjærester.

\section{SKAM: Verdighet, dialog og demokrati}

SKAM viser at den maskuline dominansen og den symbolske volden fortsatt er virksom i ungdomskulturen, og den rammer både jenter og homofile gutter. Likevel har jeg vist at ungdommene i serien ikke er fullt ut styrt av disse tunge dypstrukturene. SKAM-seriens popularitet skyldes i stor grad at den viser hvordan ungdommer kan synliggjøre, problematisere og overskride de undertrykkende strukturene. SKAM viser hvordan ungdom i fellesskap skaper et frigjørende verdighetsprosjekt. Individene kan ikke oppnå verdighet alene, kun gjennom dialog og anerkjennelse fra andre. Forankret i gode vennskap våger aktørene i SKAM å utfordre den maskuline dominansen. SKAM har blitt omtalt som dårlig skjult skole-TV, og det er åpenbart at serien har en ambisjon om å bidra til refleksjon og opplysning (Dahl \& Lindtner, 2018).

Serien målbærer en sterk tro på dialogens frigjørende potensial, noe som gjør det nærliggende å knytte an til den tyske sosiologen og filosofen Jürgen Habermas (1999). Hos ham er kommunikativ handling et nøkkelbegrep: Menneskelig samhandling formidles i stor grad gjennom språket, og som språkbrukende vesener motiveres vi av gode grunner, det Habermas kaller «kraften i de bedre argumenter». Gode argumenter gir motivasjon og gjør livet meningsfullt. Dette er også demokratiets kjerneidé: Gode argumenter skal ideelt sett avgjøre i politiske debatter, ikke 
tvang eller størrelsen på lommeboken. SKAM viser ikke bare at veien til individuell verdighet går via fellesskap og dialog, men målbærer også de demokratiske kjerneverdiene som vårt samfunn er tuftet på.

En samtale mellom Sana og Yosef (sesong 4, episode 9) er et godt eksempel på hvordan serien framhever betydningen av dialog, verdighet og demokratiske verdier. De to diskuterer grunnleggende verdispørsmål. Yosef tilkjennegir at han tror sosial tilhørighet er det dypeste menneskelige behovet. «Egentlig er alle helt like», sier han, og alle tror de er på lag med de gode. Det finnes imidlertid ikke noe som er godt eller ondt, hevder han, «bare masse mennesker som prøver å stå sammen i grupper for ikke å være aleine». Til dette tilføyer han at alle mennesker er likeverdige, og demokratiet er nettopp «bygget på ideen om at alle mennesker er like mye verdt». «Om Skam er representativ som et uttrykk for en kulturell bevegelse bort fra den liberalistiske frihetsforståelsen, mot en forståelse av at frihet ikke kan etableres uavhengig av (et grenseoverskridende) fellesskap, vil fremtiden vise.» (Lindtner \& Skarstein, 2018, s. 22)

\section{Avslutning}

Vi har lover mot seksuell trakassering i Norge. Likevel klarer ikke rettsvesenet å gi kvinner reell beskyttelse mot trakassering. Det finnes sterke uformelle reguleringer av kjønn og seksualitet. Den maskuline dominansen opprettholdes. Den symbolske volden er fortsatt virksom, ikke bare i SKAM, men også i samfunnet for øvrig. Statsadvokat Erik Førde bekrefter dette i et intervju med Aftenposten: «Vi er så opptatt av den negative muslimske æreskulturen, men vi evner ikke å se at vi finner nøyaktig de samme elementene i vår kultur. Det er kvinnene som må bære æren og moralen i samfunnet.». ${ }^{10}$ Det foreslås nå endringer i lovverket, lavterskeltilbud og økt fokus på seksualundervisningen i skolen etter SKAM og \#metoo. Det gjenstår å se om dette bidrar til at den maskuline dominansen blir borte over tid.

Vi kommer imidlertid ingen vei hvis vi ikke erkjenner at vi alle i større eller mindre grad er preget av de kjønnede dypstrukturene. Jeg har i 
denne artikkelen vist hvordan dette gjelder for karakterene i SKAM, men det er selvsagt også tilfellet for lærere, på alle nivåer i utdanningssystemet. Lærere som vil skape gode dialoger med sine elever, må derfor reflektere over sine egne kulturelle blindsoner, slik at de ikke ubevisst medvirker til å opprettholde den maskuline dominansen og heteronormativiteten.

Jeg har i denne artikkelen vist hvordan SKAM kan gi ungdom en bedre forståelse av seg selv og sine omgivelser. Skal lærerne også bidra, er det ikke tilstrekkelig at de reflekterer over de kjønnede dypstrukturene. I tillegg må de kommunisere om tabubelagte temaer på en måte som når fram til ungdommene. Da er det viktig at lærerne ikke framstår som gravalvorlige. «Humoren er en av sivilisasjonens mest pålitelige allierte», påpeker antropologen Jan Brøgger (1976, s. 70). Humor og selvironi letter på trykket, virker ufarliggjørende. Dette er også et bevisst grep serieskaper Julie Andem bruker i SKAM:

Humor i seg selv fjerner skam. Vi prøver å få til gjennom hele serien at både karakteren og seeren kan le av det utilstrekkelige, uten å ta brodden av det dramatiske. Og så vil vi vise dem verdien av å konfrontere frykt. Det handler ikke om alle andre, men hva du selv kan få til. Det kommer en mestringsfølelse fra å stå i det som er vanskelig, og konfrontere problemer. Den mestringsfølelsen bygger selvbildet. ${ }^{11}$

Humor er et skritt mot å undergrave doxa, humoren tydeliggjør at dypstrukturene er sosiale konstruksjoner: De er skapt av mennesker, og kan derfor også forandres av mennesker.

SKAM har hatt stor betydning for hvordan vi snakker om seksuelle krenkelser, homofili og andre religioner i den norske offentligheten. Det er nå opp til lærere å ta stafettpinnen videre inn i klasserommene.

\section{Forfatterpresentasjon}

Rønnaug Sørensen er universitetslektor i sosiologi, Institutt for kultur, religion og samfunnsfag, Fakultet for humaniora og utdanningsvitenskap ved Universitetet i Sørøst-Norge. Hennes forskning retter seg mot kjønn,

11 http://rushprint.no/2016/o4/nerven-i-skam-skal-vaere-sterk-og-relevant/ 
seksuell trakassering og mannsdominans. Hun har publisert artikler og bøker om kjønn, jentegrupper, seksuell trakassering og SKAM.

\section{Referanser}

Andersen, E. R. (2017). https://www.aftenposten.no/digital/-Tar-du-et-sexbilde-aven-jente-under-18_-blir-du-domt-Tar-du-bilde-av-en-gutt-under-18_-gar-du-fri10127b.html

Bakken, A. (2017). Ungdata. Nasjonale resultater 2017. NOVA Rapport 10/17.Oslo: NOVA.

Berger, P. L. (1970). On the Obsolence of the Concept of Honour. European Journal of Sociology, 11(2), 339-347.

Bile, A., Hertz, N. \& Sror, S. N. (2017a). http://fett.no/lansering-av-fett-12017skamlos-i-oslo/

Bile, A., Hertz, N. \& Sror, S. N. (2017b). Skamløs. Oslo: Gyldendal.

Bourdieu, P. (1977). Outline of a theory of practice. Cambridge: Cambridge University Press.

Bourdieu, P. (200o). Den maskuline dominans. Oslo: Pax forlag.

Brøgger, J. (1976). Roller og rollespill - Innføring i atferdsanalyse. Oslo: Cappelen Forlag.

Baarøy, F-A. (2017). http://www.hf.uio.no/ikos/forskning/aktuelt/aktuelle-saker/ 2017/na-kan-du-studere-religion-i-skam.html

Dahl, J. M. \& Lindtner, S. S. (2018). Skam3 - empati som demokratisk ressurs. I S. S. Lindtner og D. Skarstein. Dramaserien Skam. Analytiske perspektiver og didaktiske muligheter. Bergen: Fagbokforlaget.

Endsjø, Ø. (2009). Sex og religion. Oslo: Universitetsforlaget.

Faldalen, J I (2016). http://rushprint.no/2016/o4/nerven-i-skam-skal-vaere-sterk-ogrelevant/

Fett nr. 2. (2015). \#jeg har opplevd.

Forman, A. (2016). http://www.ascentofwoman.com/

Forssberg, M. (2005). Kukbruk. En bok om kjorlighet, følelser og kjønn. Oslo: Spartacus.

Frønes, I. (2013). Å forstå sosialisering. Oslo: Gyldendal akademiske forlag.

Fuglehaug, W. (2017). Det store sviket: ceresvold og ceresdrap i Norge. Oslo: Kagge.

Giddens, A. (1976). New Rules of Sociological Method. London: Hutchinson.

Habermas, J. (1999). Kraften i de bedre argumenter. Oslo: Universitetsforlaget.

Haug, F. (1990). Moralens tvekjønn. Sosiologi i dag 3/90.

Helseth, H. (2006). Ingen her på skolen er horer. (Masteroppgave), Oslo:

Universitetet i Oslo. http://hdl.handle.net/10852/15578

Helseth, H. (2010). Generasjon sex. Oslo. Forlaget Manifest. 
Honneth, A. (2008). Kamp om anerkjennelse. Oslo: Pax forlag.

Likestillingsombudet (2017). CEDAW 2017: Ombudets rapport til FNs kvinnekomité - et supplement til Norges niende periodiske rapport. http:// www.ldo.no/globalassets/brosjyrer-handboker-rapporter/rapporter_analyser/ rapporter_diverse/cedaw2017.pdf

Melhuus, M. (2001). Hvilken skam uten ære? I: T. Wyller, Skam: perspektiver på skam, are og skamløshet $i$ det modrene. Oslo: Fagbokforlaget.

Nilsen, R. Å. (1998). Mellom Apollon og Dionysos - Max Weber og det moderne menneskets strevsomme habitus. I: R. Å. Nilsen \& P. Veiden (Red.), Sosiologisk fantasi. Oslo: Ad Notam Gyldendal.

Nilsen, R. Å. (2005). Max Webers komparative historiske sosiologi - metodiske betraktninger. Arbeidsnotat nr. 188, Høgskolen i Nord-Trøndelag.

Norberg, K. H. (2013). Ansvarlig seksualitet. (Doktorgradsavhandling) Institutt for arkeologi, konservering og historie, Det humanistiske fakultet, Universitetet i Oslo.

Olsen, T. (2016). 25-åringen tilsto og ble dømt for voldtekt - likevel mener retten han hadde et «berettiget håp» om sex. http://www.aftenposten.no/norge/25aringen-tilsto-og-ble-domt-for-voldtekt-----likevel-mener-retten-han-hadde-etberettiget-hap-om-sex-608063b.html

Skarstein, D. \& Lindtner, S. S. (2018). Innledning. I: S. S. Lindnter \& D. Skarstein. Dramaserien Skam. Analytiske perspektiver og didaktiske muligheter. Bergen: Fagbokforlaget.

Skeggs, B. (1999). Att bli respektabel: Konstruksjoner av klass og kön. Gøteborg: Bokforlaget Didalos.

Sveen, H. H. (2016). Såpass må du tåle. Oslo: Humanist forlag.

Sørensen, R. (1992). Det går på verdigheten løs! I: M. Brandtsæther \& K. Widerberg (Red.), Sex i arbeid(et). Oslo: Tiden.

Sørensen, R. (2018). Jentefellesskapet i Skam. I: S. S. Lindtner \& D. Skarstein (Red.), Dramaserien Skam. Analytiske perspektiver og didaktiske muligheter. Bergen: Fagbokforlaget.

Tjora, A. (2017). Kvalitative forskningsmetoder i praksis. Oslo: Gyldendal akademisk. Trettebergstuen, A. \& Nylund, B. (2017). HOMO. Oslo. Pitch forlag.

VG Helg temanummer 20.8.2016 (flere forfattere). https://www.buyandread.com/ pub/Schibsted-publisher_schibsted/VG-verdensgang/VG\%2oHelg-verdensgang_ helg/2016-08-20-20160820/VG\%2oHelg\%2020.08.16.htm

Wikan, U. (2008). Om are. Oslo: Pax forlag.

Wilken, L. (2008). Pierre Bourdieu. Oslo: Fagbokforlaget.

Ås, B. (1979). De fem hersketeknikker - om ufarliggjøring av undertrykkerens våpen. Årbog for kvinderet. København: Kvinderetlig Skriftserie. 



\title{
Menneskeverd og menneskerettighetsundervisning
}

\section{En sosialsemiotisk multimodalitetsanalyse og drøfting av verdighetsbegrepet i filmen A Path to Dignity: The Power of Human Rights Education}

\section{Eva Maagerø}

\author{
Universitetet i Sørøst-Norge
}

\section{Ådne Valen-Sendstad \\ Universitetet i Sørøst-Norge}

\begin{abstract}
This chapter is an analysis and discussion of the globally popular human rights education film: A Path to Dignity: the Power of Human Rights Education. The film is produced by Ellen Bruno and is a cooperation with the UN department OHCHR and the human rights education organisations HREA and SGI. The film combines human rights education and dignity. Our research question is how human rights education and dignity is presented and understood in the film. The film is organized in three parts, and addresses Indian children, a Muslim woman and police in Australia. We have analysed the part about the young children in India. In our discussion of the film we have applied social semiotic theory and related analytical tools. We have analysed the representations, interactions and composition of the film. The result of the analysis shows a focus on the local situation of the children. Through human rights education the children experience a transformation in gaining a sense of dignity. This leads to a particular concern for others whose dignity is violated. The state that is responsible for their human rights is not addressed. The film presents human rights education with an interest for individual children, and dignity is understood morally, as responsibility for the other.
\end{abstract}

Keywords: Dignity, Human rights education, United Nations, Multimodality

Filmen A Path to Dignity: The Power of Human Rights Education er en populær film i menneskerettighetsundervisningen (MRU), hyppig vist

Sitering av denne artikkelen: Maagerø, E. \& Valen-Sendstad, Å. (2019). Menneskeverd og menneskerettighetsundervisning: En sosialsemiotisk multimodalitetsanalyse og drøfting av verdighetsbegrepet $\mathrm{i}$ filmen A Path to Dignity: The Power of Human Rights Education. I Å. Valen-Sendstad \& I. R. Christensen (Red.), Menneskeverd - en utfordring for skole og samfunn (Kap. 6, s. 141-168). Oslo: Cappelen Damm Akademisk. https://doi.org/10.23865/noasp.90.ch6.

Lisens: CC BY-NC 4.o. 
i store deler av verden. Dignity, eller verdighet på norsk, er et normativt og fundamentalt grunnbegrep i menneskerettighetene (MR). Til tross for begrepets sentrale rolle er det uklart hva det betyr. På bakgrunn av dette og filmens store utbredelse også i undervisning er det av betydning å undersøke hvordan filmen formidler og oppfatter verdighet.

Artikkelen har to formål. For det første ønsker vi å gjøre en analyse av filmen ut fra et sosialsemiotisk rammeverk for å avdekke noe av filmens meningspotensial. For det andre ønsker vi å diskutere framstillingen av verdighet i filmen. Vi vil ut fra dette forsøke å besvare to spørsmål: Hva slags meningspotensial finner vi i filmen? Hvordan forstås og kommuniseres verdighet i filmen? Vi går særlig inn på den delen av filmen som dreier seg om MRU med barn i India.

Nedenfor presenteres først filmen og bakgrunnen for den og deretter noen sentrale betydninger av begrepet verdighet og utvalgte modeller for MRU. Vi gjør så rede for den sosialsemiotiske tilgangen vi benytter for å analysere filmen som multimodal tekst, og for selve analyseverktøyet. Videre blir den sosialsemiotiske analysen presentert, før framstillingen av verdighet i filmen diskuteres i forhold til noen sentrale forståelser av verdighet.

\section{Presentasjon av filmen}

Filmen A Path to Dignity: the Power of Human Rights Education er laget av den anerkjente amerikanske regissøren Ellen Bruno i samarbeid med SGI (SokaGakka International, en buddhistisk fredsorganisasjon), Human Rights Education Associates (HREA) og The Office of the United Nations High Commissioner for Human Rights (OHCHR). Den ble vist for første gang på en tilstelning ved UN Human Rights Council i Genève i 2012 og har senere blitt vist på menneskerettighetsarrangementer over hele verden. Filmen er påkostet med opptak i flere deler av verden og med versjoner på flere språk (arabisk, kinesisk, engelsk, fransk, japansk, russisk og spansk). De tre organisasjonene som står bak filmen, sier at de har følgende mål med den: [We] «have jointly produced this film as a tool to raise awareness about the positive role that human rights education can play in fulfilling human rights.» De sier videre at de 
ønsker å vise den kraften som ligger i utdanning, og at hovedbudskapet er: «One person can make a difference.» Filmen er med andre ord tenkt som en pedagogisk ressurs, og det er utarbeidet oppgaver som seerne kan arbeide videre med, og slik fordype seg i filmens tematikk. Filmen har en egen hjemmeside, ${ }^{1}$ og her understrekes betydningen av utdanning og den pedagogiske dimensjonen som er tiltenkt filmen. Det heter blant annet:

Human rights education can transform people's lives, empowering individuals on a path to dignity and bring about positive change in their respective communities and societies. In this sense, human rights education plays a fundamental role in ensuring equality and equal opportunities, combating discrimination and preventing human rights violations.

Filmen er 28 minutter lang og består av tre deler eller caser som viser hvordan utdanning i menneskerettigheter har hatt betydning for skolebarn i India, politiet i Melbourne, Australia og kvinnelige voldsoffer i Tyrkia. De indiske barna lever i Tamíl Nadu i Sør-India. De lærer om den indiske grunnloven og om barns rettigheter og om likeverd og diskriminering, og de setter det de lærer, i forbindelse med dagliglivet sitt i skole og hjem. For politiet i Melbourne blir kunnskapen og bevisstheten om menneskerettigheter viktig i måten alt politiarbeid utføres på, og også måten den enkelte politimann og -kvinne ser på mennesker de møter i arbeidet sitt på. I Tyrkia lærer kvinner om menneskerettigheter gjennom ukentlige workshoper, og de får innsikt i hvilke muligheter de har som kvinner til å få et likeverdig og godt liv. De tre delene er rammet inn av bilder av sjø som slår mot en strand, og sjøen eller havet blir et sammenbindende element, nærmest en metafor for at vi alle hører sammen. I tillegg vises innslag av personer som informerer om ulike former for arbeid med menneskerettigheter og verdighet, og om hva dette har hatt å si for dem vi møter i filmen. Informasjonen gis både av personer som arbeider for menneskerettigheter regionalt, og av mer internasjonale størrelser som Laura Chinchilla Miranda, som var president i Costa Rica fra 2010 til 2014, og i en periode FNs høykommissær for menneskerettigheter. I

1 Se: https://www.youtube.com/watch?v=ahEotJbvl78 
tillegg til informasjonen fra personer vises det dessuten plakater med tekst som gir konsentrert informasjon om forhold som de som står bak filmen, åpenbart ønsker at skal framheves. Plakatene tjener det pedagogiske budskapet.

\section{Teoretisk ramme}

\section{Verdighet i en menneskerettighetskontekst}

Verdighet, iboende verdighet, et liv i verdighet og menneskeverd er sentrale begreper i MR-konvensjoner. Slik konvensjonene er bygd opp, er verdighet grunnsteinen som rettighetene bygger på: «Dignity is ... what grounds all our rights» (Waldron, 2012, s. 17). På denne bakgrunnen er det ikke overraskende at en film om MRU spiller på nettopp verdighetsbegrepet. I denne delen trekker vi fram noen elementer i forståelsen av dette begrepet, hentet fra diskusjonen om innholdet i begrepet.

En av røttene til begrepet er naturretten, hvor verdighet oppfattes som iboende, noe mennesket har i seg selv fordi hun er menneske. Maritain sier mennesket innehar «intrinsic worth and dignity» (Maritain, 1952, s. 88). Menneskerettighetshistoriker Johannes Morsink (2009) hevder at de som utviklet Verdenserklæringen for menneskerettigheter, hadde en naturrettslig tolkning av verdighetsbegrepet. Han mener videre at dette er en umistelig dimensjon ved MR. Ifølge Morsink må forestillingen om en metafysisk dimensjon ved mennesket holdes i live for at MR skal ha en universell forankring og legitimitet. Det er noe ved mennesket som gir henne en unik verdi, en spesiell verdi blant annet liv; mennesket besitter «a mysterious essential human quality» (Bostrom, 2005, s. 209). Denne forståelsen er det også vanlig å legge til Kant (Gewirth, 1996, s. 66), selv om det også er andre lesninger av hans forståelse av verdighetsbegrepet (se Arntzens kapittel i denne boka og dessuten Sensen (2011, s. 174-214)). Mennesket har verdi i seg selv og ikke fordi det er til nytte, men derimot er et formål i seg selv.

Når dette verdighetsbegrepet blir så viktig i moderne MR-diskurs, er det blant annet fordi menneskeverdet knyttes til ethvert menneske. Mennesker må ikke kvalifisere seg til verdighet, det er nok å være menneske (Nussbaum, 2007). I flere konvensjoner og i barnekonvensjonens 
artikkel 2 er det en omfattende liste over hvem som dekkes av konvensjonen. Alle barn har barns rettigheter, og alle mennesker har menneskerettigheter.

Andre forståelser av menneskeverdet avviser metafysiske tolkninger og søker i stedet immanente forståelser av begrepet, som Fukuyama (2002, s. 149) som hevder at mennesket har en «en x-faktor». En annen med en slik forståelse er Dworkin. Han konstruerer verdighetsbegrepet over to prinsipper. For det første består det av selvrespekt: «Dignity requires self-respect» (Dworkin, 2011, s. 204) og videre: «I must recognize the objective importance of my living well» (Dworkin, 2011, s. 205). Han forutsetter at det å være menneske innebærer at man tar sitt liv på alvor, og har en form for selvrespekt. Dette innebærer at man tar et ansvar for sitt liv og forsøker å gjøre det beste ut av det. Fokuset er på eget liv og å realisere det så godt som mulig. Det andre prinsippet i Dworkins verdighetsbegrep er autentisitet: «expressing yourself in your life, seeking a way to live that grips you as right for you» (Dworkin, 2011, s. 209). Autentisitet er å leve sitt liv på egne premisser. Man utvikler og følger sin egen plan for hvordan man ønsker å leve sitt liv, utvikler den stilen eller karakteren man selv ønsker seg. Selvrespekt innebærer å ta sitt liv på alvor, autentisitet er å gjøre sitt liv til noe personlig og unikt. Livet skal fylles med noe man genuint ønsker seg i den konteksten man lever i.

En annen dimensjon som er interessant, er hans bro mellom verdighet som et moralsk og et etisk begrep. Dworkin gjør verdighetsbegrepet til et grunnbegrep i sin etikk. Etikk handler om hvordan den enkelte kan leve gode og meningsfylte liv. Det verdige livet leves ut i et individuelt rom. I Dworkins anvendelse av moralbegrepet handler moral om hva som er felles normer og verdier for samfunn. Dette skal være normer og prinsipper som er forpliktende, objektive, upartiske - gyldige for alle. Dworkin anvender verdighetsbegrepet til å bygge bro mellom etikk og moral. Han bygger sin moralteori på et kantiansk prinsipp: «If you are to respect yourself, you must treat their (all human beings) lives, too, as having objective importance» (Dworkin, 2011, s. 255). Verdighet utvikles av Dworkin som en etisk verdi, individets gode liv, men han gjør det også til en grunnverdi i sin teori om moral. Hans resonnement er enkelt: Hvis 
du tar ditt eget liv på alvor fordi det er viktig for deg, da må du samtidig tilkjenne og respektere at også andre må kunne gjøre det samme. Andre må også få anledning til å leve sine liv i verdighet, med selvrespekt. I det ligger den moralske forståelsen av verdighet, man får et ansvar ikke bare for seg selv, men også for andre.

Et annet aspekt ved verdighetsbegrepet er koblingen mellom verdighet og transformasjon. Begrepet har i deler av MR-diskursen en klar politisk betydning og knyttes til og er en brekkstang for samfunnsendringer. Beitz (2013, s. 288) forstår begrepet politisk og argumenterer for at verdighet er en verdi som fremmes gjennom MR: «a value advanced by a public practice of human rights». Den politiske forståelsen er enda mer eksplisitt hos inderen Baxi (Baxi, 1997). MR er for han et instrument for de undertrykte og skal først og fremst være et redskap til å endre livsvilkårene for de marginaliserte gruppene i samfunnet. Det er de som trenger MR. Det er de som skal løftes til et verdig liv. MR er i dette perspektivet normer forankret i de undertryktes kamp for verdighet.

Felisa Tibbitts (Tibbitts, 2002, 2017) har analysert MRU globalt og mener den kan organiseres i 3 hovedmodeller:

1. Verdi- og bevissthetsmodellen: Modellen er gjerne forbundet med offentlig og formell utdanning på ulike nivåer. Undervisningen gir en innføring i historie og bakgrunn for rettighetene, herunder filosofiske begrunnelser for dem. Det er videre sentralt å arbeide med betydningen av rettighetene og de institusjonene som forvalter dem.

2. Den ansvarliggjørende modellen: Denne modellen er rettet mot profesjoner som er særlig ansvarlige for MR i utøvelsen av sine "professional roles» (Tibbitts, 2002, s. 165). Hun nevner grupper som jurister, personer i offentlige tjenester og medisinsk personell, altså profesjoner som arbeider med sårbare grupper, som politifolk i filmen. En annen gruppe i filmen er lærere. De er ansvarlige for MR overfor elever og foreldre. De er forpliktet til å respektere elevers rettigheter, som retten til medvirkning og privatliv.

3. Transformasjonsmodellen: Modellen tilbys gjerne av NGO-er og er rettet mot mennesker som er krenket og undertrykt. Ofrene skal 
skoleres og mobiliseres gjennom undervisningen. Målet er politisk og å endre samfunnsforhold. Ambisjonen er å skape aktivister (Mihr \& Schmitz, 2007), mennesker som vil engasjere seg i kampen for MR og mot krenkelser av MR, for eksempel kvinnegrupper eller grupper som arbeider for minoriteters rettigheter.

Disse tre modellene for MRU gjenspeiler betydelige forskjeller i hva prosjektet MRU innebærer. Den første modellen vil i mindre grad medføre endringer, den andre utvikler profesjonalitet blant yrkesgrupper med ansvar for MR, mens den siste modellen er en radikal politisk endringsmodell, med betydelig gjennomslag i MRU-miljøer. I den delen av filmen som vi går inn på, er det særlig modell 2 og 3 som gjenspeiles. Dette kommer vi tilbake til nedenfor.

\section{Sosialsemiotikk og multimodalitet}

Som bakgrunn for analysen av filmen har vi valgt sosialsemiotisk multimodalitetsteori. Sosialsemiotikk ble utviklet av den britiske lingvisten Michael Halliday (1978). Semiotikk er ifølge Halliday (og de Saussure før ham) læren om meningsskapende tegn, og Halliday sier at all form for meningsskaping skjer i samspill mellom mennesker i sosiale kontekster. Mennesket er for Halliday primært «a social man» (Halliday, 1978, s. 9) og kommuniserer med andre gjennom systemer av tegn. For Halliday er verbalspråket menneskets viktigste kommunikasjonsmiddel, men verbalspråket realiseres hele tiden sammen med andre former for meningsskaping. Grunnleggende for språk og andre meningsskapende systemer er tre fundamentale meningstyper (eller metafunksjoner som Halliday kaller dem, se blant annet Halliday, 1994) som allid realiseres samtidig: den ideasjonelle, den mellompersonlige og den tekstuelle metafunksjonen. Den ideasjonelle metafunksjonen viser til den representasjonen som et meningsskapende system har i forhold til virkeligheten. Språk er for eksempel ikke virkeligheten, men setningene er konstruert slik at de representerer handlinger og tilstander i virkeligheten. Samtidig vil språk og andre meningsskapende systemer ha ressurser til interaksjon. Dette er den mellompersonlige metafunksjonen. Den tekstuelle metafunksjonen 
betegner Halliday (1994) som limet mellom de to andre metafunksjonene. Språket og andre meningsskapende systemer har ressurser til å binde elementer sammen til større helheter.

Sosialsemiotikere som O'Toole (1994), Kress (2010), van Leeuwen (1999, se også Kress \& van Leeuwen, 2001, 2006), Baldry og Thibault (2006) og Machin (2007) bygger på Hallidays syn på meningsskaping og har utviklet teorier og analysemetoder for andre meningsskapende systemer som visuell meningsskaping (stillbilder og levende bilder), musikk, farge, kroppsspråk m.m. De bygger i sine arbeider på de tre metafunksjonene som er presentert ovenfor, men i visuell meningsskaping bruker for eksempel Kress og van Leeuwen (2006) begrepene representasjon, interaksjon og komposisjon i stedet. Flere av de sosialsemiotikerne som er nevnt ovenfor, har i sine arbeider også vært opptatt av samspillet mellom ulike former for meningsskaping og bidratt til forståelse av multimodal meningsskaping. En modalitet kan defineres som et semiotisk (eller meningsskapende) system som har et visst potensial og en viss begrensning for å skape mening. Dette omtales som det semiotiske systemets modale affordans. For eksempel vil et bilde ha et potensial for romlig og umiddelbar meningsskaping, mens verbalspråket (som er sekvensielt) vil ha et potensial for beskrivelser og argumentasjon. Thibault hevdet i en omfattende artikkel fra 2000 at det ikke finnes noen monomodale tekster. Selv tekster i ei trykt bok, der verbalspråket absolutt er det mest framtredende meningsskapende systemet, vil ifølge Thibault være multimodale ved at verbalspråket samspiller med design på siden, fonter og papirkvalitet og dermed skaper et multimodalt uttrykk. Film er derimot en svært rik multimodal tekst der flere modaliteter samspiller. Den helhetlige meningen i samspillet blir mer enn summen av modalitetene (Thibault, 2000).

Det er også viktig å understreke at all form for meningsskaping skjer i en kontekst. Mennesker skaper mening i her-og-nå-situasjoner (situasjonskontekster), og konteksten vil påvirke hvilke valg som tas ut fra de ressursene som står til disposisjon. En film produseres for å presentere et innhold og fungere overfor tenkte seere i tenkte situasjoner. Når betrakterne ser filmen, skjer dette i konkrete kontekster som vil ha betydning for tolkningen. Samtidig vil filmen inngå i en større 
kulturkontekst som skaper en ramme for filmuttrykket, både når filmen blir produsert, og når den blir sett. Betrakteren kommer til filmen med sine personlige, men også sine kulturelle erfaringer. Derfor vil tolkningen av filmen kunne variere fra individ til individ, fra situasjonskontekst til situasjonskontekst og innenfor ulike kulturkontekster. Ut fra dette vil vi understreke at analysen i neste delkapittel vil bygge på våre tolkninger.

\section{Analysemetode}

I denne artikkelen er det en film som står i fokus. Filmer er komplekse multimodale uttrykk der levende bilder, verbalspråk (i dette tilfellet både muntlig og skriftlig verbalspråk), musikk, lyd, farger, bevegelser, gester m.m. er med på å skape den helhetlige meningen. Det er så godt som umulig å fange all form for meningsskaping i så komplekse uttrykk som film. Dessuten karakteriseres en film av stadig vekslende bilder som det ikke er meningen at skal holdes fast, men som utvikles etter hverandre sekvensielt i tid. Filmer har også en dramaturgi som viser en form for overordnet komposisjon. Vi vil i analysen av denne filmen bygge på de tre metafunksjonene nevnt ovenfor, og som Kress og van Leeuwen omtaler vi dem som representasjon, interaksjon og komposisjon.

Vi har valgt å analysere den delen av filmen som er fra Tamíl Nadu i Sør-India. Denne delen varer i 10 minutter, og det er som nevnt barn og MRU som står i sentrum. Vi legger vekten på visuell meningsskaping, og tabellen nedenfor viser hva vi vil se på i analysen. Vi kommenterer også noen trekk ved verbalspråket, særlig under interaksjon.

\begin{tabular}{|l|l|l|}
\hline Representasjon & Interaksjon & Komposisjon \\
\hline Representerte deltakere & Blikk & Oppbygning \\
Handlinger & Nærhet & Framtredenhet \\
Omgivelser & Kameravinkel & \\
Farger & & \\
\hline
\end{tabular}

\section{Analyse}

Som nevnt ovenfor vil metafunksjonene strukturere analysen av utdraget, men det er viktig å understreke at alle metafunksjoner er til stede 
samtidig i alle deler av filmen. Film er som medium lineær ved at framstillingen presenteres i en rekkefølge fra begynnelse til slutt. Men enkelte filmer har ikke-lineære trekk (Engelstad \& Tønnessen, 2011, s. 60) og byr på scener fra ulike steder og tidspunkter som holdes sammen av for eksempel voiceover. Slik er denne filmen.

\section{Representasjon}

I denne delen av analysen er det viktig å identifisere de representerte deltakerne i filmen, handlingene deres og omgivelsene rundt handlingene. De representerte deltakerne i den delen av filmen som vi har valgt ut for analyse, er skoleelever, lærerne deres og personer tilknyttet organisasjoner som arbeider med menneskerettigheter. De tre gruppene har ulike oppgaver. Barna skal lære om menneskerettigheter og vise at det er mulig å endre på urettferdige forhold i dagliglivet. Lærerne har som oppgave å undervise barna om menneskerettigheter og være en støtte for dem når de ønsker å endre noe i nærmiljøet sitt. Personene fra menneskerettighetsorganisasjonene er Navi Pillay (FNs høykommissær for menneskerettigheter på den tiden filmen ble laget), Henri Tiphagne (direktør for People's Watch) og Mariasoosai Selvaraj (nasjonal programkoordinator ved Institute of Human Rights Education, People's Watch). De informerer om menneskerettigheter blant annet ut fra menneskerettighetserklæringen og andre dokumenter og understreker hvor viktig undervisning er for å oppnå rettferdighet for alle og et verdig liv. De løfter temaene som presenteres, til et mer globalt nivå. Filmen veksler mellom å framstille de to første gruppene, barna og lærerne, som gruppe og som enkeltindivider. Det siste gjøres ved å fokusere på noen representanter for gruppen.

Barna kan tolkes som de viktigste representerte deltakerne i denne delen av filmen. Det er de som er målet for undervisningen, det er de som skal endre samfunnet sitt til et bedre sted å være, og det er de som er framtiden. Barna blir hovedsakelig vist på skolen, i klasserommet og i skolegården, men også i noen tilfeller på skoleveien og hjemme. De bærer skoleuniformer, og dette blir et viktig attributt som styrker 
skolens betydning i filmen. Det er derfor barna som elever og skolen som kontekst som understrekes. Skolekonteksten settes med en gang i åpningen av en kort sekvens som kommer før selve presentasjonen av filmens tittel og annen informasjon. Bilder av føtter som går på en buss, vises, og en guttestemme benyttes som voiceover. Han snakker sitt eget språk, og det han sier, oversettes til engelsk og presenteres i skrift: «In the teashop, the lower caste is served in cocunut shells and the upper class is served in steel cups. And with the teacher's help, we solved that problem. I told them, 'I will report this as a human right violation'». Mens gutten snakker, skifter bildet over til klasserommet og viser et nærbilde av ham foran ei tavle (se bilde 1 nedenfor). Hovedtema for den indiske delen av filmen presenteres konsentrert her i åpningen: Mye urettferdighet skjer i dagligdagse situasjoner som i tehuset, men også barn har makt til å endre urettferdige situasjoner hvis de lærer om menneskerettigheter. Samtidig understrekes det at læreren er viktig. Hun eller han er den støtten barna trenger for å kunne endre. Menneskerettigheter knyttes også til et klasseproblem der de fattige forskjellsbehandles, og utsettes for krenkelser.

Etter dette begynner selve den indiske delen av filmen, og bildet skifter til Navi Pillay. Hun leser menneskerettighetserklæringen som ble proklamert av det nyåpnede FN i 1948. Bildet skifter først tilbake til det seerne oppfatter som et klasserom, der et nærbilde av ei jente vises, før det igjen skifter over til en skolegård der hvite krittblomster er tegnet inn. Klasserommet er spartansk innredet uten bilder på veggene og uten annet pedagogisk materiale enn tavle og kritt. Jenta gir inntrykk av å følge godt med mens Navi Pillay avslutter med å si: «The full realization of human rights requires all human beings to be aware of their and other people's rights and of their means to ensure their protection.» Ved denne elliptiske klippemåten (Engelstad \& Tønnessen, 2011, s. 96) skapes det en sterk forbindelse mellom elevene og menneskerettighetene, men barna, som andre, må bli klar over rettighetene sine. Her kan skolen hjelpe gjennom undervisning i menneskerettigheter. Filmen viser også flere ganger hvordan lærere tar opp dette temaet i klasserommet. Elliptisk klipping går igjen i filmen. 

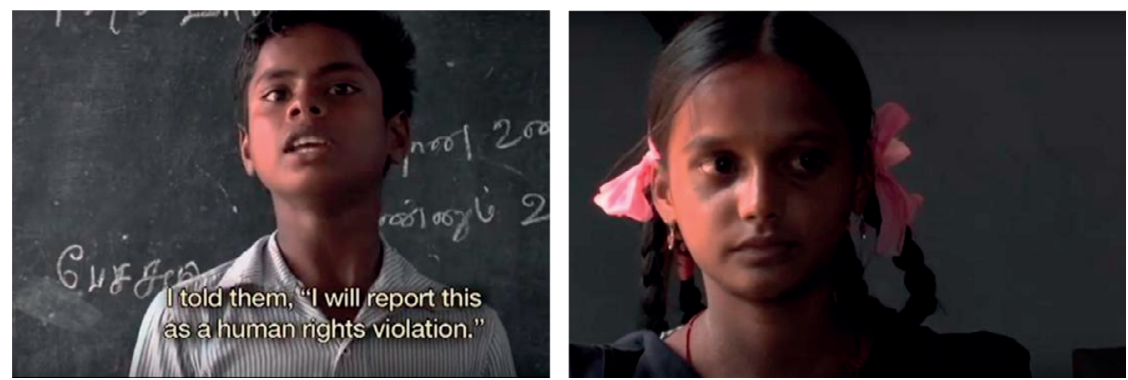

Bilde 1 og 2. Barn i Tamíl Nadu. Bildene er hentet fra A Path to Dignity. (C) Human Rights Education Associates (HREA), Soka Gakkai International (SGI), Office of the United Nations High Commissioner for Human Rights (OHCHR), 2012.

Jenta i bilde 2 kan tolkes som hovedpersonen i filmen. Hun har skoleuniform som de andre elevene, men blir også presentert med navn, Premalatha, i hvit skrift i et av bildene, noe som styrker hennes individualitet. Under navnet står det skrevet «Human rights student». Som de andre elevene kommer hun fra fattige kår. Dette understrekes gjennom klipp fra hennes verden: en vannpost med mange voksne og barn som kommer for å hente vann, kjøkkenet hjemme der jenta hjelper til med matlaging og veien til skolen i buss. I disse klippene er det mye reallyd, som biler som tuter, skraping, mennesker som snakker osv., noe som understreker den naturalistiske representasjonen (se Kress \& van Leeuwen, 2006). Disse sekvensene knyttes til jenta ved hjelp av voiceover. Hun er i klasserommet og forteller om det hun opplever som krenking av menneskerettigheter, mens filmen viser scener fra de stedene som nevnes. Hun sier blant annet: «In our village, my family is of lower caste. When I fetch water from the tap the others take water first and only then we can get some. If we say: 'We came here first' they mock us and ask: 'Why are you talking so much being from a lower caste?'» Senere i filmen bringes også kjønnsperspektiv inn gjennom denne jenta. Hun vises igjen i nærbilde, krever oppmerksomhet gjennom blikket (Kress \& van Leeuwen, 2006) og sier: «My parents make me do all the work - never my brothers. Only boys are valued and supported in my family, not at all girls. I ask why the boys can't help. You gave birth to all of us. Why am I the only one who has to work? They say, 'The boys will take care of us until we die. But you will go away.'» Jenta forteller også at hun blir slått, og at ei jente i landsbyen satte fyr på seg selv fordi foreldrene oppførte seg dårlig mot henne. 
Temaet tas opp igjen mot slutten av filmen i et klipp der jenta reflekterer over sin stilling som kvinne mens hun leker med en papegøye i bur, et kraftig symbol på ufriheten mange kvinner opplever. Menneskerettigheter handler med andre ord ikke bare om kampen mot urettferdighet i et klassesamfunn, men også om kvinners kamp for et verdig liv.

Selv om jenta kommer fra den laveste kasten, er hun framstilt på det vi kan kalle en verdig måte. Hun har en tydelig stemme i klasserommet i tillegg til at hun er ren og velstelt. Det rosa sløyfebåndet hennes (og de andre jentenes, også i sterke farger eller i hvitt) lyser opp og skiller seg ut fra de mørke og nokså triste omgivelsene og framstår som det vi med Kress og van Leeuwen (2006) kan kalle et symbolsk attributt, et objekt som viser en symbolsk verdi (Machin, 2007, s. 63). Machin (2007, s. 70) sier: «The meaning potential of brightness rests on the fundamental experiences we have with light and dark (...). Bright can be associated with moods such as happy ...». I dette tilfellet kan det rosa sløyfebåndet knyttes til verdighet og selvrespekt til tross for fattige kår og vanskelig livssituasjon, kanskje til og med til håp.

En annen enkeltelev blir trukket fram gjennom voiceover, for eksempel når Henri Tiphagne snakker mens scener fra landsbyen, klasserommet og skolegården vises. Til slutt vises et nærbilde av en gutt i klasserommet. Tiphagne snakker om underkasten som tidligere ble kalt «the Untouchables», og som i dag ofte betegnes som «Dalits». Han sier: «People who are upper class consider them, the Dalits, to be impure. For a young boy running into school ... just because he comes from the Dalit community, he may not be allowed to eat along with the others, because the spillover from his plate should not fall into somebody else's plate.» Når dette sies, løfter gutten hodet. Slik blir «det urene» koblet til ett enkelt barn, noe som gir en sterk virkning i filmen.

Lærerne er som nevnt over, den andre gruppen deltakere. De blir vist i klasserommet der de underviser i menneskerettigheter, og i en sekvens der de selv er på kurs i menneskerettigheter. De har ikke en like framtredende plass i filmen som de to andre gruppene, men de er et viktig bindeledd mellom ideene om menneskerettighetene og dokumentene disse er nedfelt i, og elevene. På kurset er det Henri Tiphagne som underviser. I filmen zoomes det inn på både mannlige og kvinnelige deltakere, og de gir inntrykk av å lytte konsentrert og følge godt med. Kameraet zoomer 
også inn på tre bilder på veggen der særlig et portrett av Gandhi er tydelig. Det er opplyst av dekorasjonslys og pyntet med en krans. Slik knyttes Gandhi og hans ikkevoldsfilosofi til det Tiphagne sier: «We started with the words 'human rights' $\ldots$ and then we tried to understand what was Dalit human rights. We understand that these are very powerful words. But who are we? Who are we? All those who are working for the promotion or the protection of human rights, of all people, we are all human rights defenders.» Gjennom ordet dalit knyttes det et bånd til elevene som er presentert tidligere i filmen.

Særlig to kvinnelige lærere får spesiell oppmerksomhet og blir representanter for lærergruppen. De er begge kledd i fargerike sarier, bærer smykker og er velstelte. Fargene skaper kontraster til de enkle omgivelsene slik fargene på elevenes sløyfebånd gjør, og gir kraft til personene (se van Leeuwen, 2011). Den ene læreren vises i nærbilde rett etter kurssituasjonen, og navnet hennes kommer opp i bildet: K. Jothimani, Human rights teacher, Theni District.

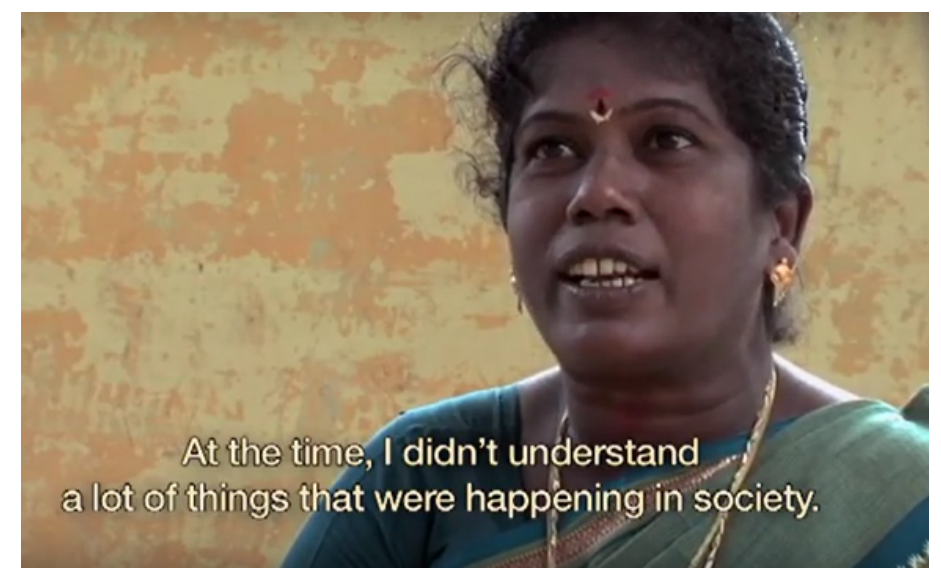

Bilde 3. K. Jothimani. Bildet er hentet fra Path to Dignity. (C) Human Rights Education Associates (HREA), Soka Gakkai International (SGI), Office of the United Nations High Commissioner for Human Rights (OHCHR), 2012.

Jothimani sier på sitt eget språk (som oversettes til engelsk tekst): «The first time I attended the human rights training was in 2001. At the time, I didn't understand a lot of things that were happening in society. Human rights ... We didn't even know what it was or what it meant. We went to 
the training programme and there we learned a lot.» Etter at hun har sagt dette, skifter bildet til et klasserom, og slik skapes sammenhengen mellom det hun har lært på kurs, til det hun og andre lærere nå kan lære elevene. Den andre læreren underviser i klasserommet som ble presentert i begynnelsen av filmen. Læreren står foran tavla og skriver (oversatt) «The rights of the child». Det hun sier, blir tekstet til engelsk: «We have a lesson in human rights education on the rights of the child, the right to play, the right to freedom of expression, and the right to liberty.» Innholdet er med andre ord knyttet til barn og barns perspektiv. Læreren inviterer elevene til å skrive på tavla og ber dem skrive «the right to liberty» og «the right to freedom of movement». Hun prøver med andre ord å engasjere elevene i temaet, noe også elevenes presentasjoner av urettferdighet i dagliglivet skulle bidra til (se ovenfor). Det zoomes også inn på jenta vi møtte tidligere i filmen, og det skapes en sammenheng mellom det hun kjemper for i hverdagen sin, og det hun har lært av læreren.

Den tredje gruppen er de som arbeider med menneskerettigheter i organisasjoner. Det dreier seg i den indiske delen av filmen om tre personer (se ovenfor). De tre har som tidligere nevnt som oppgave å trekke forbindelser mellom ideene om menneskerettigheter og konkrete situasjoner i samfunnet representert ved elever og lærere i Tamíl Nadu. De representeres først og fremst gjennom voiceover og gjennom nærbilder i nøytrale omgivelser (mot en vegg eller et tekstil) der de snakker inn i kameraet.

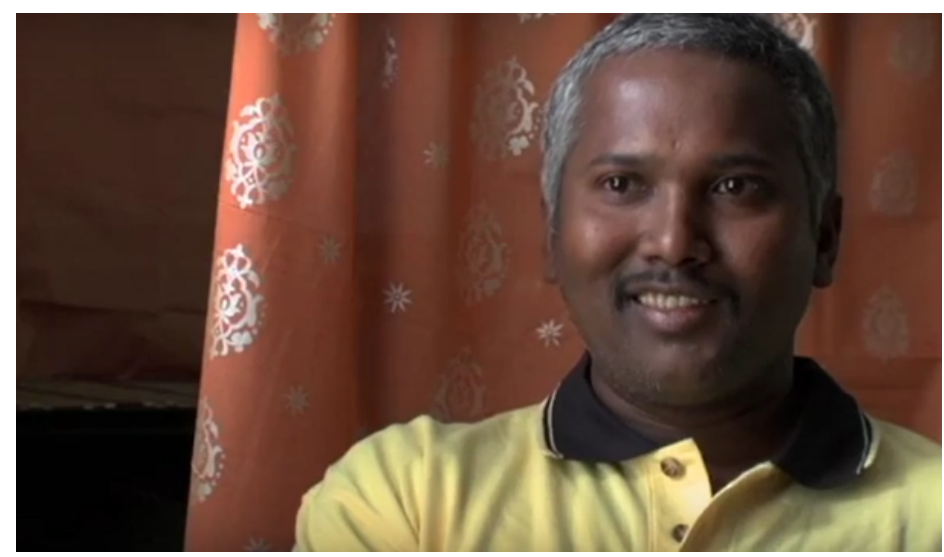

Bilde 4. Mariasoosai Selvaraj. Bildet er hentet fra A Path to Dignity. (C) Human Rights Education Associates (HREA), Soka Gakkai International (SGI), Office of the United Nations High Commissioner for Human Rights (OHCHR), 2012. 
Navi Pillay tar utgangspunkt i menneskerettighetserklæringen, mens Henri Tiphagne særlig kommenterer det elevene tar opp i skolen, og dessuten temaer som lærerne på kurs i menneskerettigheter må kunne. Mariasoosai Selvaraj (se bilde 4) understreker viktigheten av å presentere menneskerettighetene for myndighetene slik at alle barn kan få undervisning i menneskerettigheter og forbedre sin egen situasjon. Han hevder at det ikke er mulig å forandre foreldrene. Det er barna man må satse på. Hans budskap er: «Each child can make a change through practising the human rights value. That is important.»

\section{Interaksjon}

I dette delkapitlet skal vi ta opp hvilke grep som gjøres for å skape kontakt mellom filmen og seerne. Machin (2007, s. 116) sier: «In images as in real life, distance signifies social relations.» Nærbilder av de representerte deltakerne er et grep som er svært tydelig i filmen, og dette grepet gjør det lettere for betrakterne å identifisere seg med de representerte deltakerne. Det skapes et intimt forhold mellom disse personene og seerne. Når elevene kommer med sitt budskap, er de nær oss, og de snakker direkte til oss. Det samme gjelder læreren som forteller om opplæringen hun har fått i menneskerettigheter, og det gjelder de tre representantene for menneskerettighetsorganisasjonene. I flere klipp ser i tillegg de representerte deltakerne rett inn i kamera. Blikket rettes mot seerne, og det kreves oppmerksomhet (Kress \& van Leeuwen, 2006, s. 120). Blikk er et svært viktig kontaktskapende middel, og seerne vil føle at de tiltales direkte. Et tydelig eksempel på dette er gutten som innleder filmen (se bilde 1). Han ser rett inn i kameraet og krever at seerne hører på det han har å si om hvordan den laveste kasten blir behandlet i tehuset. Siden en så stor del av filmen fra India har nærbilder av de representerte deltakerne, får filmen et sterkt pedagogisk preg. Som seere belæres vi om urettferdighet, og om hvordan kunnskaper om menneskerettigheter kan bøte på denne urettferdigheten. De tre representantene for menneskerettighetsorganisasjonene er vist svakt fra siden og har ikke blikket rettet rett mot kameraet. De krever derfor ikke oppmerksomhet gjennom blikket slik noen av barna gjør. Kontakten mellom seerne og barna blir derfor i flere tilfeller sterkere enn mellom 
seerne og disse representantene. Barna snakker mer til følelsene, mens de tre representantene mer har en opplysende funksjon.

Kameravinkel er også et viktig filmatisk grep. I sekvenser med nærbilder er ofte kameravinkelen nøytral, dvs. at den representerte deltakeren som snakker, er i samme høyde som seerne, og det skapes et symmetrisk forhold mellom dem (Machin, 2007, s. 117; Kress \& van Leeuwen, 2006, s. 134). Slik er det i bilde 2 ovenfor. Men i noen tilfeller er den som snakker, filmet nedenfra slik vi ser i bilde 1. Da får personen som snakker, ekstra makt (Kress \& van Leeuwen, 2006, s. 136). Seerne ser opp mot ham, og han ser ned i kameraet. Dette er med på å gjøre innledningssekvensen viktig. Gutten krever oppmerksomhet samtidig som han gis makt til å formidle budskapet sitt.

Når oversiktsbilder fra klasserommet, skolegården og landsbyen vises, er personene opptatt med ulike gjøremål. De henvender seg ikke direkte til seerne, men til hverandre, eller de er henvendt mot forskjellige objekter. I klasserommet er elevene gjerne vendt mot læreren og tavla. De lytter mens læreren underviser, eller de går fram og skriver på tavla. Seerne kan observere disse aktivitetene, men blir ikke trukket inn i dem. I slike sekvenser tilbys seerne informasjon (Kress \& van Leeuwen, 2006, s. 134). Informasjonen i bildene understøtter og utfyller det som sies av de representerte deltakerne, gjerne parallelt som voiceover. Disse sekvensene er viktige fordi de konkretiserer det som tas opp gjennom verbalspråket, og lar seerne få et innblikk i leveforhold hjemme og på skolen.

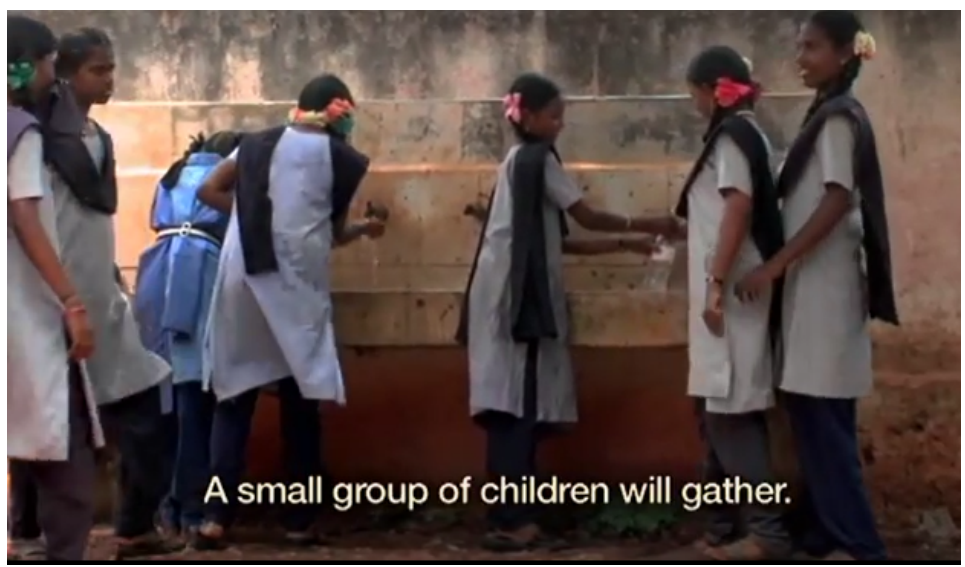

Bilde 5. Barn i Tamíl Nadu. Bildet er hentet fra A Path to Dignity (c) Human Rights Education Associates (HREA), Soka Gakkai International (SGI), Office of the United Nations High Commissioner for Human Rights (OHCHR), 2012. 
Akkurat som bilder kan verbalspråket kreve handlinger eller informasjon av lytterne eller tilby informasjon. Når handlinger eller informasjon kreves, skjer det gjerne ved imperativer eller spørsmål som stilles til dem som hører på. Når informasjon tilbys, skjer det gjerne gjennom konstaterende setninger. I filmen henvender riktignok de representerte deltakerne seg direkte til seerne, men det er allikevel informasjon som tilbys, og ikke kreves, gjennom verbalspråket. Både elevene, læreren og de tre representantene fra menneskerettighetsorganisasjonene benytter konstaterende setninger. Lytterne kan ta imot informasjonen og være enig i den, eller de kan benekte den. Men det kreves ikke gjennom språket at lytterne skal gjøre noe aktivt. To eksempler kan illustrere dette. Navi Pillay sier følgende i begynnelsen av filmen: «All human beings are born free and equal in dignity and rights. The full realization of human rights requires all human beings to be aware of their and other people's rights and of their means to ensure their protection.» Mot slutten av filmen sier en av elevene (tekstet på engelsk): «My neighbours forced their 13-yearold daughter to get engaged. We asked her parents why. They said it was because they were poor. We told them, 'This is wrong. You should allow your daughter to get an education.' So they allowed her to stay at school and called off the wedding. She is in the $9^{\text {th }}$ grade now.» Begge informerer de lytterne gjennom verbalspråket, men ber ikke eksplisitt lytterne om å handle. Dette er typisk for den indiske delen av filmen. Gutten forteller at de derimot henvendte seg direkte til jentas foreldre og krevde noe av dem. Dette skjer flere ganger i filmen, både gjennom det barna forteller, og i klasserommet når læreren ber elevene gjøre noe. Men dette formidles til lytterne uten krav til dem.

\section{Komposisjon}

En film består av sekvenser som er ordnet etter tid. Den begynner et sted og slutter et annet. Når vi studerer filmens komposisjon, er vi opptatt av rekkefølgen på sekvensene, med andre ord hvordan vi som seere blir ført gjennom filmen (Engelstad \& Tønnessen, 2011). Det er ikke noe tydelig høydepunkt i den delen av filmen som foregår i India. Den har en flat struktur der sekvens avløser sekvens til den går over i den neste delen 
(politiet i Melbourne, Australia). Denne delen av filmen er knyttet til ett sted, Tamíl Nadu i Sør-India, og stedet binder filmen sammen. Det er mulig at representantene for organisasjonene befinner seg et annet sted, men de knyttes til stedet gjennom bruk av voiceover. Filmen veksler mellom nærbildene av representanter for de tre gruppene som snakker direkte til seerne, og sekvenser fra nærmiljøet som klasserom, skolegård, på bussen, ved vannposten, på kjøkkenet til jenta osv. (se over). Denne vekslingen danner en slags rytme i filmen. Engelstad og Tønnessen (2011, s. 103) sier at «korte innstillinger i rask rekkefølge egner seg til dramatisk og actionpreget handling, mens lange dvelende innstillinger kan gi signaler til tilskueren om noe spesielt betydningsfullt i det visuelle forholdet». Lengden på sekvensene varierer, men hver sekvens oppleves som nokså lang, og særlig talesekvensene gis stort omfang. Selve budskapet får dermed oppmerksomhet. Som tidligere nevnt binder voiceover delene sammen og blir et svært viktig grep for å skape sammenheng. Gjennom voiceover får dessuten de representerte deltakerne som snakker, formidlet mye informasjon på kort tid. Voiceover blir derfor også et grep som tjener filmen som opplysnings- og undervisningsfilm.

Også andre elementer holder filmen sammen. For eksempel er det noen barn som går igjen, særlig jenta som er presentert ovenfor. De andre barna som uttaler seg i filmen, er dessuten alltid framstilt som elever i skoleuniformer og med klasserommet som bakgrunn. Skolekonteksten er også med på å skape sammenheng og styrker undervisningsbudskapet i filmen. Også lærerne på kurs i menneskerettigheter understreker formidling av undervisning. Det samme gjør det som formidles gjennom verbalspråk ved at det er ord som «human rights» som går igjen, men også ved at eksempler på krenkelse av menneskerettigheter går igjen, alltid etterfulgt av at det går an å gjøre noe med urettferdighet.

Et kompositorisk trekk er plakater som er klippet inn i filmen. Plakatene er svarte og har hvit skrift. Den første kommer etter at Henri Tiphagne har tatt opp oppfatningen om at den laveste kasten er uren. Tiphagne er, som tidligere nevnt, direktør i People's Watch, og på plakaten står det: «People's Watch is actively engaged in training teachers in government schools throughout India. Teachers learn to conduct human rights education programmes for children in grades 6, 7 and 8.» De tre 
andre plakatene som vises, er rett etter at Mariasoosai Selvaraj er introdusert. På den første står det: «United Nations human rights education initiatives, such as the ongoing World programme for Human Rights Education, encourage governments and civil society to develop effective human rights education programmes.» På den andre står det: «Since 1997, human rights educators have reached out to over 300 ooo Indian school children», og på den tredje «In addition to learning about the Indian Constitution, the children develop an understanding of the rights of the child, and the principles of non-discrimination and equality, and how these apply to their daily lives.» Den siste plakaten kommer helt mot slutten av filmen etter sekvensen med jenta og papegøyen i bur (se ovenfor). Det står: «International human rights law requires governments to train all government workers in human rights, including the military and the police, health workers and other civil servants.» Mens denne plakaten vises, er det reallyd i bakgrunnen. Stemmer høres, og det snakkes engelsk. Dette blir overgangen til neste del om politiet i Melbourne. Også ordet «police» på plakaten forbereder denne overgangen. Verbalteksten på alle plakatene tar opp undervisning i menneskerettigheter, og de understreker derfor hovedbudskapet i filmen. Plakatene framstiller en slags essens av det denne delen av filmen formidler.

Hvis man skulle trekke fram ett trekk som er framtredende i filmen, så må skoleelevene nevnes. Barnas stemme er den tydeligste ut fra komposisjonen i filmen. Det er barna som kommer med de mest konkrete eksemplene på urettferdighet, og det er barna som henvender seg mest direkte til seerne (se ovenfor). Samtidig er det barnas verden som får størst plass, ikke minst gjennom klipp fra klasserommet og skolegården. Dette er barnas arenaer, og det er barn som hele tiden vises. Ikke minst er de fargerike sløyfebåndene til jentene med på å gjøre dem framtredende i alle klipp der de er til stede.

Analysen ovenfor har vist at budskapet i filmen er at undervisning $\mathrm{i}$ menneskerettigheter nytter. Når barn tar opp urettferdighet i sine omgivelser, blir forhold endret til det bedre. Lærere slutter å slå elevene, jenter får gå på skole, den laveste kasten blir mer respektert, osv. Undervisning har kraft, og barna er framtidshåpet. Dette budskapet formidles på en svært tydelig måte gjennom visuelle og verbalspråklige virkemidler. Det 
blir for eksempel ikke problematisert at fattigdom ofte kan ødelegge de aller beste hensikter, og at kjønnsroller stikker dypt. Selv om de fleste vil være enige i at opplysning og undervisning er avgjørende for å få til samfunnsendringer, ser denne delen av filmen ut til å presentere en automatikk mellom undervisning og endring. Bare barn får høre om menneskerettigheter, kan de endre sin situasjon.

\section{Verdighetsbegrepet i filmen}

Filmens tittel er A path to dignity. The path, stien, er et bilde på den vandringen og utviklingen som barna skal oppleve gjennom MRU. Barna blir, slik vi analyserer filmen, klar over sin verdighet gjennom undervisningen i menneskerettigheter. Filmen framstiller i utgangspunktet barn som ikke er bevisst på at de er bærere av verdighet. Med andre ord er verdighet noe man kan inneha uten å kjenne til det. Det er en blanding av noe naturgitt og noe man må tilføres gjennom kunnskap. Elevene får åpnet sine øyne og ser på seg selv på en ny måte, de oppdager sin iboende verdighet. Fordi man er menneske, innehar man verdighet uavhengig om man er klar over det eller ei. Den nyvunne innsikten endrer deres syn på seg selv og verden omkring. Jenta som er hovedpersonen i denne delen av filmen, sier at rettighetene (MR) er «birth rights», noe man er født med, mens en av lederne sier «all human beings are born free and equal in dignity and rights», klassiske referanser til naturrettstenkning.

Innsikten i det å være født med verdighet endrer selvforståelsen til jenta og de andre barna i filmen. Analysen av filmen viste at dette temaet er viktig på flere nivåer. Lærerne som er MRU-lærere, viser tilbake til sin egen utdanning. Før de begynte å lære om MR, var de uten innsikt og forståelse for mangelen på rettigheter, og vi legger til verdigheten som rettighetene bygger på. På samme måte som MRU endret lærernes selvforståelse, slik endrer deres undervisning elevene.

Vi så tidligere at Dworkin oppfattet menneskets verdighet som en kombinasjon av to faktorer. Den ene var autentisitet. Den framstår i møte med barnas virkelighet og deres utfordringer med grunnleggende hindringer i hverdagen som et vestlig ideal, som ikke treffer situasjonen i filmen. Den andre dimensjonen var selvrespekt. Det er mer relevant i filmens 
kontekst. Det innebærer å ta sitt liv på alvor og ville gjøre det beste ut av det. Selvrespekt synes å være en viktig dimensjon ved filmens forståelse av verdighet. Elevene får gjennom innsikten i MR tilgang til sin egen verdighet. Dette gjenfinnes i filmen gjennom framstillingen av barna, som jenta med kjole og sløyfe i håret. Det medfører også at barna står opp for seg selv med tyngde og autoritet. De konfronterer til og med mennesker rundt seg, og de stoler på sine tolkninger av situasjoner. MRU tilfører og avdekker for barna deres verdighet, og det medfører selvrespekt og mot.

MRU er i filmen framstilt på en måte som korresponderer godt med hva Tibbitts kaller transformativ MRU. I denne delen er det en transformasjon av hvordan elevene ser på seg selv. Transformasjonen framkommer i filmens komposisjon, representasjon og interaksjon. MRU er en «mindchanger», et avgjørende element $\mathrm{i}$ å skape et samfunn basert på verdighet og MR.

\section{Verdighet i hverdagen}

Analysen av filmen viser en vektlegging av barnas hverdag. Mye urettferdighet skjer i dagligdagse situasjoner. Det er to viktige poenger som analysen av filmen viser. For det første har barna hovedrollene i den delen vi analyserer. Barna løftes opp og presenteres med verdighet, og det understrekes at barn har verdighet. Det andre poenget er at barnas hverdag vektlegges. Urettferdigheten er noe barna møter rundt seg i måter de blir behandlet på. Barnas verdighet har med hverdagen å gjøre.

Filmen engasjerer seg særlig med erfaringer som barn fra svakere stilte grupper har. På tehuset blir barn fra de øvre kastene servert med metallkropper, mens de fra lavkastene får te servert i kokosnøttskall. Jenta som tilhører en lav kaste, blir ignorert og må vente til de fra høyere kaster er ferdige med å tappe vann, selv om hun var der først. Barn fra lavkaster, jenter og de kasteløse dalitene blir i framstillingen i filmen gjennomgående behandlet med verdighet $\mathrm{i}$ kontrast til hverdagens mangel på respekt og verdighet.

I analysen viste vi situasjonen til jenta, Premalatha, som er hovedpersonen i den delen vi diskuterer. Hun blir i sin egen familie utsatt for diskriminering. Etter å ha blitt en MR-elev avdekker hun og tar tak i krenkelsen av hennes verdighet som urettferdigheten innebærer. Hun krever av sine 
foreldre en begrunnelse for den skjeve fordelingen av plikter i hjemmet, hvorfor brødrene hennes slipper husarbeidet.

Dalitene nevnes eksplisitt. De kan ikke spise sammen med mennesker fra høyere kaster fordi de kan komme til å søle mat på deres mat, og da blir maten uren. Anvendt på dalitenes situasjon blir menneskeverdighet et særlig sterkt budskap. De som i det indiske samfunnet ikke har plass ved bordet, får gjennom MRU en helt annen posisjon. Dalitene har samme verdighet som alle andre. I lys av et samfunn hvor verdighet $\mathrm{i}$ generasjoner er vevd sammen med blod og kaste, er dette et svært radikalt budskap. Verdighet er noe alle har, og det innbefatter likeverd.

\section{Verdighet og transformasjon}

Et viktig poeng i filmen som viser seg på alle de tre analysenivåene, er at MRU virker. I et tradisjonsbundet samfunn som barna i filmen lever i, er det at barn har verdighet i seg selv et radikalt budskap, en del av transformasjonen. Filmen framhever, som analysen påpeker, at barna har makt. De filmes med kameravinkler som kompositorisk understreker dette, og de krever oppmerksomhet fra tilskuerne med blikket sitt. De forteller stolt om hvor effektive de har vært når de har grepet inn i situasjoner på vegne av andre. Lærere sluttet å slå. Tehuset sluttet å servere lavkaster i kokosnøttskall, og foreldrene som skulle gifte bort datteren, gjorde det ikke etter at en gutt i filmen hadde grepet inn på vegne av jenta. Barnas virke som MR-agenter gir resultater. Barn har makt; de kan endre verden.

Målet med MRU er, slik den indiske MRU-pedagogen Bajaj forstår det, et prosjekt for «social change». Tanken i filmen, som analysen påpekte, er at hvis man begynner med barna og endringene av dem og deres omverden, så vil det endre samfunnet og etablere en MR-kultur. Filmens visjon er et langsiktig prosjekt. Verdigheten har politiske konsekvenser. Fortellingene i filmen fokuserer, som vi har påpekt flere ganger, på barns hverdag. Transformasjonen skjer på det nære planet. Barn kan omforme samfunn med sitt engasjement. Et liv i verdighet leves i hverdagen slik som Eleonore Roosevelt beskrev det i sin berømte tale fra 1958, «In our hands»: «Where, after all, do universal human rights begin? In small 
places, close to home - so close and so small that they cannot be seen on any maps of the world» (Roosevelt, 1958)

\section{Verdighet - et moralsk anliggende}

Tidligere så vi hvordan Dworkin anvendte verdighetsbegrepet som et moralsk begrep. På det moralske nivået argumenterte han for at det å ta sitt eget liv på alvor med nødvendighet innebar å respektere at andre har de samme ønskene for sine liv som en selv. Andre har i likhet med en selv krav på selvrespekt. Andre skal også kunne leve ut sine liv på en god måte. I det ligger moralen: Man må respektere andre og deres rettigheter.

I filmen trekkes dette moralske anliggendet enda lenger enn hos Dworkin. I flere av eksemplene i filmen handler barna uselvisk for andre. Bajaj kaller det «coalitional agent» (Bajaj, 2012, s. 77). Man ser uretten som rammer andre, og engasjerer seg på vegne av dem. Gutten som nevnes i analysen, involverer seg for jenta som er i ferd med å bli giftet bort av foreldrene. Han snakker og argumenter med foreldrene til jenta. Han er en agent for MR og andres verdighet. Et sentralt budskap i denne delen av filmen er dette moralske perspektivet. I filmen innebærer det moralske ikke bare å respektere egen og andres verdighet, men også aktivt å engasjere og involvere seg på de ufrie og undertryktes side, å gjøre noe aktivt for å endre forholdene, og bidra til at andre får et verdig liv. Hovedfokus er ikke på en selv, slik det er for Dworkin. I filmen er verdigheten noe man har, men det er også en væremåte. Et liv i verdighet innebærer et ansvar og engasjement for andre. Det er en uselvisk dimensjon i verdigheten.

\section{Noen kritiske perspektiver}

Filmen velger å sette fokus på hva verdigheten gjør med barna, hvordan de endrer sin selvforståelse, og hvordan de tar ansvar for mennesker rundt seg. MRU og verdighet handler om det daglige liv. Resultatet er at begrepet først og fremst formidles som et moralbegrep. Et spørsmål som da reiser seg, er: Hvem er det som har forpliktet seg på MR? Det er stater, og det er stater som krenker MR. I filmen er staten ikke gjenstand for kritikk eller 
ansvar, tvert om siden det pedagogiske opplegget som presenteres, blir gjennomført i statlige skoler. Den egentlige adressaten for MR unnslipper. De som i filmen krenker MR, er enkle mennesker, naboer som selv i liten grad kontrollerer sin situasjon, som selv gjerne er produkter av undertrykkelser. Den juridiske dimensjonen ved MR-prosjektet er fraværende i filmen. MR-konvensjoner er juridiske dokumenter, lover som forplikter stater. Verdighet blir i filmen nærmest et privatisert og individualisert anliggende.

I filmen tilfører MRU barna et nytt perspektiv på seg selv, og endringer skjer hurtig og framstår som ukompliserte. Filmen ignorerer hvor dypt kulturens påførte selvforståelse stikker. MRU er nærmest et magisk opplegg som effektivt tar et oppgjør med kulturen. Gamle og tunge tradisjoner og institusjoner som organiserer mennesker i kaster, underkommuniseres. Filmen adresserer mangelen på rettigheter og menneskeverd som kvinner erfarer. Jenta, hovedpersonen, stiller spørsmål om hvorfor hun behandles annerledes enn brødrene, hvorfor hun har så mange plikter, mens guttene slipper unna. Hun får et svar om at hun må hjelpe til nå, for senere skal hun forlate foreldrene, og brødrene vil da ta ansvaret for foreldrene. De strukturelle forholdene som er årsakene til fattigdom, uvitenhet og kjønnsroller er utelatt i filmen. Det er til en viss grad forståelig, man kan ikke ta med alt, men problemet er at filmen hopper over de dypere årsakene til fattigdom og kjønnsroller.

Denne delen av filmen bygger på en langsiktig politisk visjon som eies av pedagogene. I første omgang er det viktig å endre barn som så på sikt kan endre kulturen og politikken. Transformasjonen av samfunnet skal skje gjennom transformasjon av barna. Prosjektet er presentert som et nedenfra-prosjekt. Barna er kompetente subjekter. De avdekker overtramp mot MR, de handler og endrer. Det hele skjer på barnas premisser - eller gjør det det? Barna er engasjerte og får ting til, pedagogikken har virket og den er effektiv, men i hvilken grad er det barna selv? Man kan spørre om de blir marionetter for NGO-enes visjoner og politiske ambisjoner. Vi tolker at filmen bygger på en pedagogikk basert på Freires (Freire, 1996) frigjøringspedagogikk der de undertrykte selv må handle, men den mangler kritiske blikk på kompleksiteten i en pedagogikk som initieres av lærere (Rancière, 1991) (Ely-Yamin, 1993), men som så skal overtas av elevene og være elevenes egen. 


\section{Konklusjon}

Filmen framstiller en sterk kobling mellom MRU og verdighet. Forståelsen av verdighetsbegrepet er en blanding av ulike tolkninger av begrepet, men med en klar forankring i en naturrettslig forståelse. I filmen frambringer MRU forståelse av verdighet hos elevene og gjør det effektivt og virkningsfullt. Filmen hevder at verdighet er en fødselsrett, det er noe man er født med og til. Samtidig er det ikke noe man nødvendigvis har umiddelbar tilgang til. MRU opplyser elevene om deres egen verdighet, noe som leder til selvrespekt. Innsikten leder videre til handling. Uselvisk tar elevene initiativ på vegne av andre; de griper inn til støtte for dem som er mer utsatt enn dem selv. Verdighetsbegrepet gis en moralsk tolkning. Det er en måte å leve på i relasjon til andre.

Med filmens fokus på elevene blir statens ansvar for MR langt på vei usynliggjort. Ansvaret blir barnas moralske ansvar. Det juridiske er så godt som usynlig. Filmen er basert på en politisk visjon, og den formidler en tro på at kombinasjonen MRU og verdighet innebærer politisk og kulturell transformasjon. Det politiske verdighetsprosjektet blir et uendelighetsprosjekt som en gang langt, langt fram i tiden vil realiseres. Den tror på det å starte i det små. Når mange nok barn har fått MRU, vil transformasjonen finne sted. Kanskje er det utilsiktet, men den politiske dimensjonen ved verdighetsbegrepet blir svak og utydelig. Filmen går etter vår mening for langt i privatiseringen av MR-prosjektet. Det er de nære relasjoner som adresseres, mens de dypere maktstrukturer langt på vei slipper unna kritikk. I filmen har verdighet med hverdagen å gjøre, og det er barna selv som skal stå for omveltningen. Selv om barn engasjerer seg for lokale forhold, trenger en transformasjon en endring av økonomiske, politiske og kulturelle maktstrukturer. Filmen framstår dermed som noe naiv og med et romantisk syn på verdighet, MRU og transformasjon, og den undervurderer potensialet og rekkevidden av de funksjonene verdighetsbegrepet rommer.

\section{Forfatteromtale}

Eva Maagerø er professor i norsk på Universitetet i Sørøst-Norge, Institutt for språk og litteratur og underviser i lærerutdanninga. Hennes 
forskningsinteresser er sosialsemiotikk, systemisk funksjonell lingvistikk, multimodalitet og literacy.

Ådne Valen-Sendstad er førsteamanuensis ved Universitet i Sørøst-Norge ved Fakultet for humaniora, idrett og utdanningsvitenskap. Han har en PhD fra University of Birmingham. Han arbeider med etikk, filosofiske forståelser av menneskerettigheter og menneskerettighetsundervisning. Han har publisert om menneskerettigheter i skolen, barnets beste, demokrati og normativ pluralisme.

\section{Referanser}

Bajaj, M. (2012). Schooling for Social Change: The Rise and Impact of Human Rights Education in India. New York, London, New Delhi, Sydney: Bloomsbury.

Baldry, A. \& Thibault, P. (2006). Multimodal Transcription and Text Analysis: A Multimedia Toolkit and Coursebook. London: Equinox.

Baxi, U. (1997). Human Rights Education: The Promise of the Third Millennium? In G. J. Andreopoulos \& R. P. Claude (Eds.), Human Rights Education for the Twenty-First Century (pp. 142-154). Philadelphia: University of Pennsylvania Press.

Beitz, C. R. (2013). Human Dignity in the Theory of Human Rights: Nothing But a Phrase? Philosophy \& Public Affairs, 41(3), 259-290.

Bostrom, N. (2005). In Defense of Posthuman Dignity. Bioethics, 19(3), 202-214.

Dworkin, R. (2011). Justice for Hedgehogs. Cambridge, Massachusetts and London, England: The Belknap Press of Harvard University Press.

Ely-Yamin, A. (1993). Empowering Visions: Toward a Dialectical Pedagogy of Human Rights. Human Rights Quarterly, Vol. 15 No. 1, 640-685.

Engelstad, A. \& Tønnessen, E. S. (2011). Film. En innføring. Oslo: Cappelen Damm Akademisk.

Freire, P. (1996). Pedagogy of the Oppressed. London: Penguin Books.

Fukuyama, F. (2002). Our Posthuman Future. New York: Farrar, Straus and Giroux.

Gewirth, A. (1996). The Community of Rights. Chicago, London: The University of Chicago Press.

Halliday, M. A. K. (1978). Language as social semiotics. The social interpretation of language and meaning. London: Open University Press.

Halliday, M. A. K. (1994). An Introduction to Functional Grammar. London: Edward Arnold.

Kress, G. (2010). Multimodality. A social semiotic approach to contemporary communication. London: Routledge. 
Kress, G. \& van Leeuwen, T. (2001). Multimodal Discourse. London: Bloomsbury Academic.

Kress, G. \& van Leeuwen, T. (2006). Reading Images: A Grammar of Visual Design. London: Routledge.

Machin, D. (2007). Introduction to Multimodal Analysis. London: Bloomsbury Academic.

Maritain, J. (1952). Man and the State. New York: The University of Chicago Press.

Mihr, A. \& Schmitz, H. P. (2007). Human Rights Education (HRE) and Transnational Activism. Human Rights Quarterly, Vol. 29, 973-993.

Morsink, J. (2009). Inherent Human Rights: Philosophical Roots of the Universal Declaration. Philadelphia: University of Pennsylvania Press.

Nussbaum, M. C. (2007). Frontiers of Justice; Disability, Nationality, Species Membership. Cambridge, Massachusetts \& London, England: The Belknap Press of Harvard University Press.

O’Toole, M. (1994). The language of displayed art. New Jersey: Leicester University Press.

Rancière, J. (1991). The Ignorant Schoolmaster. Stanford: Stanford University Press.

Roosevelt, E. (1958). In our Hands. Retrieved from http://www.un.org/en/ globalissues/briefingpapers/humanrights/quotes.shtml

Sensen, O. (2011). Kant on Human Dignity. Berlin and Boston: De Gruyter.

Thibault, P. (2000). The Multimodal transcription of television advertisement: theory and practice. I: A. Baldry (Red.): Multimodality and Multimediality in the distance learning age. Campobasso: Palladino Editore.

Tibbitts, F. (2002). Understanding What We Do: Emerging Models for Human Rights Education. International Review of Education, Vol. 40 No. 3-4, 159-171.

Tibbitts, F. (2017). Evolution of Human Rights Education: Conceptual perspectives In M. Bajaj (Red.), Human Rights Education; Theory, Research, Praxis.

Philadelphia: PENN, University Pennsylvania Press.

van Leeuwen, T. (1999). Speech. Music. Sound. London: Macmillan.

van Leeuwen, T. (2011). The Language of Colour: An Introduction. London:

Routledge.

Waldron, J. (2012). Dignity, Rank, \& Rights. Oxford, New York: Oxford University Press. 


\title{
KAPITTEL 7
}

\section{No mercy no dignity}

\section{Refleksjoner over et kunstnerisk utviklingsarbeid i Ål kyrkje}

\section{Tollef Thorsnes}

\section{Universitetet i Sørøst-Norge}

\begin{abstract}
This chapter discusses questions of dignity and mass migration addressed during the process of the making of a temporary art installation. The installation is located at "Ål kyrkje", a church in Hallingdal in Norway. As the writer of this chapter I am both an artist making the installation and a researcher on my own art work. The chapter starts with an introduction to the concept "dignity" and a presentation of my understanding of the concept as open, dynamic and living. Different cultures and organizations assign different meanings to the concept of dignity. In my opinion, it is important to be aware of these different sunderstanding, and to try to find ways to communicate them openly and through dialog. Social semiotic theory is based on an understanding that all communication is social. This theory acknowledges the importance of roles that both the context and all the participants have in the communication. The main purpose of this chapter is to explore how I can make an art installation that does not give specific answers, but initiate visitors' experiences, dialogues, reflections and new questions about mass migration and dignity.
\end{abstract}

Keywords: Dignity, migration, art, social semiotic theory

Stammer vokser og spres _ $\quad-\quad$ Tree trunks grow and spread

I overganger øker spenningene - Transitions increase tensions

Verdigheten settes på spill _ - Dignity is at stake

Det kjennes til margen _ - $\quad$ It is felt in the midst of the tree

Margsprekker går til kjernen _ - Splits in the bosom of the tree run to its core

Det skaper åpninger — - - Openings are created

Tilbake står sprekker i fasaden $\quad$ - Cracks are left in the surface

\section{Introduksjon}

I dette kapittelet skal jeg undersøke noen problemstillinger i et kunstnerisk utviklingsarbeid om verdighet og massemigrasjon. Ål kyrkje i Hallingdal inviterte meg til å lage en kunstutstilling til temaet i

Sitering av denne artikkelen: Thorsnes, T. (2019). No mercy no dignity: Refleksjoner over et kunstnerisk utviklingsarbeid i Ål kyrkje. I Å. Valen-Sendstad \& I. R. Christensen (Red.), Menneskeverd - en utfordring for skole og samfunn (Kap. 7, s. 169-189). Oslo: Cappelen Damm Akademisk. https://doi. org/10.23865/noasp.90.ch7.

Lisens: CC BY-NC 4.o. 
forbindelse med nådebegrepet og Lutheråret 2017. Over 40 nasjonaliteter lever på Ål, ei bygd med 5000-600o innbyggere, så jeg opplevde invitasjonen som modig og inspirerende.

Hovedproblemstillingene i denne artikkelen handler om hvordan jeg kan skape en kunstinstallasjon som kan bidra til spørsmål, opplevelser, samtaler og refleksjoner om verdighet og massemigrasjon uten at noe svar er gitt på forhånd / på en åpen måte. Og kan det sosialsemiotiske rammeverket tilby gode tankeknagger i den skapende prosessen og være egnet som metode i den forbindelse? Funnene vil i tillegg til å være faglig interessante og fagoverbyggende, være relevante i tilrettelegging for læring og dannelse tilknyttet verdighet.

I denne bokens kapittel Verdighetsmagi? En sosialsemiotisk multimodalitetsanalyse og drøftelse av filmen «A path to dignity» redegjør forfatterne for sosialsemiotikk og multimodalitet. For dem som er interessert i å lese nærmere om sosialsemiotikken, henviser jeg derfor til redegjørelsen i det kapittelets teori og metode. Vanligvis anvendes sosialsemiotikken og multimodalitetsteoriene til analyse, mens jeg i dette arbeidet undersøker om sentrale teori- og analysebegreper også kan anvendes som tankeknagger i en kunstnerisk prosess. Med denne kvalitative, prosessuelle og eksplorerende metoden for å bygge og bearbeide en case, vil jeg videre utover i artikkelen reflektere over prosessen og funnene.

\section{Innledning}

Massemigrasjon som følge av klimaendringer, krig og terror er en overveldende utfordring. Det er krevende når mennesker med ulik sosial og kulturell bakgrunn møtes og må utvikle et felles samfunn. For oss i vesten kan det være naturlig å tenke at utfordringene kan løses gjennom demokrati, sekulariserte byråkratier, retningslinjer og vedtekter. Det er mye godt som kan skje ut fra denne samfunnsstrukturen. Samtidig lever store deler av verdens befolkning med andre samfunnsstrukturer og tankesett. Et betydelig antall mennesker lever for eksempel i en virkelighet som er sterkt influert av religion. Vår samtid kjennetegnes blant annet av at et større mangfold av mennesker med ulike virkelighetsforståelser møtes 
og lever sammen i byer og tettsteder. Det skaper vesentlige overganger mange steder, fra nokså monokulturelle til multikulturelle samfunn.

I tiden som kommer, vil det i enda større grad oppstå kulturelle overganger. Massive folkemengder med ulikt kulturelt og religiøst ståsted vil møtes, spenninger oppstår, og verdigheten settes på spill. Religionene kan i et globalt perspektiv ses på som institusjoner med stort ansvar for menneskers læring og dannelse, og derved grobunn for god dialog og gode multikulturelle samfunn. Her i Norge er Den norske kirke en dominerende religiøs størrelse, og dermed den religionen med mest ansvar for at verdigheten ikke kommer ut av spill. Det kan for eksempel skje ved mangel på dialog.

For at mennesker med ulike verdi- og tankesett skal kunne ha god dialog, kan verdighet være et nøkkelord. Verdighet er et begrep som forstås og utvikles på ulike måter, både innen juss, religion, filosofi og kunst. Innen kunst er det mange sterke eksempler på prosjekter som visualiserer og stiller spørsmål ved verdighet på svært uttrykksfulle måter, for eksempel kunstverk av Ai Weiwei og Marina Abramovic.

Christopher McCrudden er en av dem som har gjort et omfattende arbeid med verdighetsbegrepet. Han har drøftet det med vekt på teoretiske, filosofiske forståelser og hvordan det håndteres innen rettssystemer (McCrudden, 2014). Han oppfatter verdighetsbegrepet som en plassholder: «dignity can often function as a placeholder, accepting that there is no actual or possible agreed articulation of its content» (McCrudden, 2013, s. 11).

I denne nyere forståelsen av begrepet hevdes det at det i begrepet ligger et overskudd av betydninger, et betydningsmangfold, eller rett og slett at begrepet er åpent og gir rom for å bli fylt av betydninger.

Et av McCruddens sentrale poeng er at dette mangfoldet av betydninger baserer seg på en felles kjerne i forståelsen av verdighet: (1) at mennesket har en iboende verdighet, (2) at denne verdigheten innebærer at den også finnes i andre, og derved lar dette prege relasjonene, og (3) at staten må forholde seg til at individer har verdighet (Valen-Sendstad, 2019).

I arbeidet med kunstprosjektet til Ål kyrkje tenker jeg på verdighet som et slikt åpent begrep, og arbeider for at kunstinstallasjonen kan bidra til større bevissthet om verdighet og massemigrasjon gjennom opplevelser, interaktivitet, konstruktive samtaler og refleksjon. Kirken er en stor institusjon og 


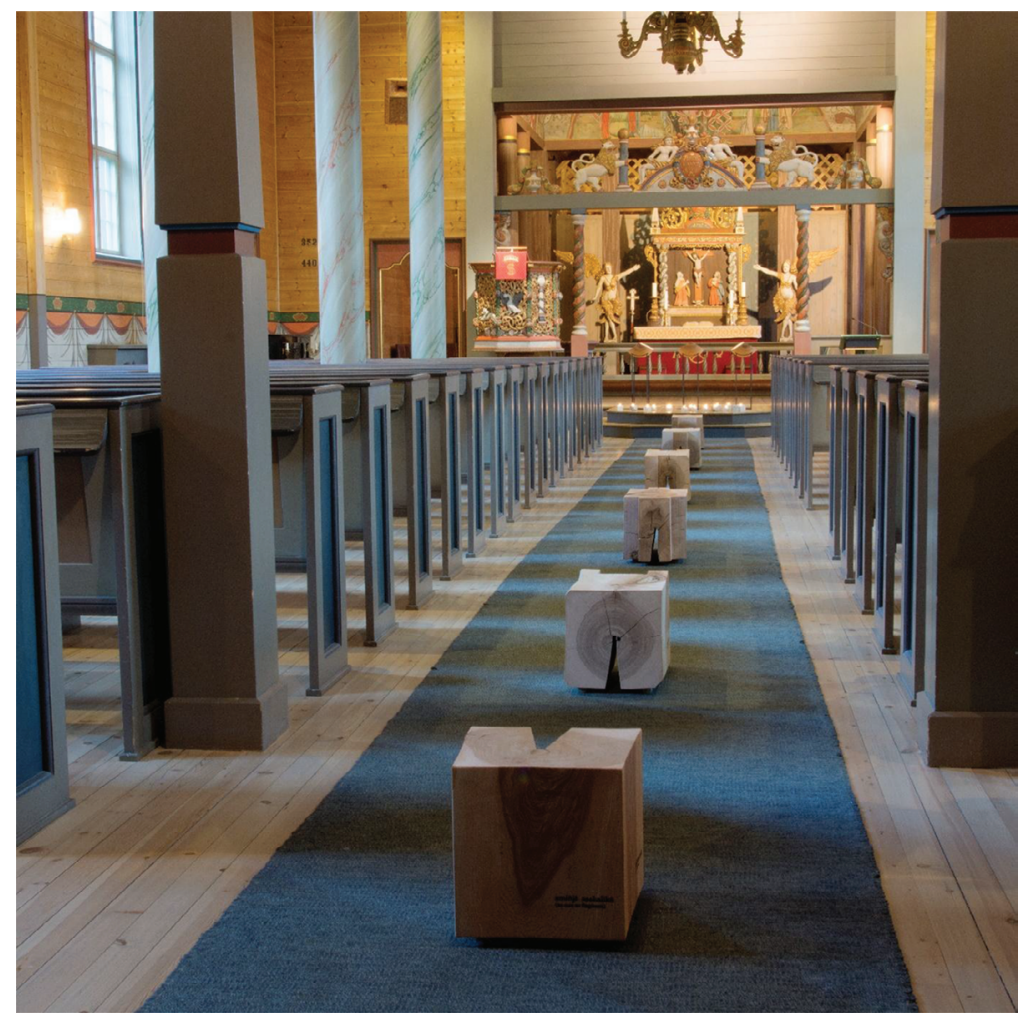

Figur 1. Fotografiet viser kunstinstallasjonen i Ål kyrkje. $\AA$ installere konstruksjonsobjekter med ca. bredde $35 \mathrm{~cm}$ og høyde $35 \mathrm{~cm}$ og varierende lengde $(50-80 \mathrm{~cm})$ i hele midtgangen i Ål kyrkje, vil til sammen kunne utgjøre et forstyrrende inngrep i rommet. Det samme gjelder plasseringen av de tre båtene foran korinngangen. (Foto: T. Thorsnes)

beveger seg langsomt, og det har vært et innarbeidet syn at kristendommen har svar på de store spørsmålene om verdighet. Kunstinstallasjonen jeg arbeider med, utfordrer og setter verdighetsforståelsen i spill. Det kan oppleves som forstyrrelser, ja kanskje til og med oppleves som provoserende.

I kunstinstallasjoner iscenesettes ofte ulike objekter og materialer i et bevisst samspill med konteksten, som for eksempel rom, lys og tid. Fordi kunstinstallasjoner benytter konteksten uttrykksmessig, blir også mottakerne ofte en del av kunstverket. De måtene mottakerne trer inn i og interagerer med kunstinstallasjonen på, er en del av det tenkte meningspotensialet. Kunstnere som arbeider med installasjoner, har derfor vanligvis ikke et budskap i form av at intendert mening skal sammenfalle med oppfattet mening. Multimodale uttrykk, som kunstinstallasjonen i Ål kyrkje, innebærer at kommunikasjonen består av flere tegnsystemer 
som samvirker i en helhet. Hvert tegnsystem, hver uttrykksmåte eller modalitet består av meningsskapende ressurser eller virkemidler. Kunstneriske uttrykksmåter eller modaliteter er for eksempel tegning, maleri, foto, skulptur, materialitet, tekst, osv. De ulike modalitetene kan formidle noe av det samme, eller de kan utfylle hverandre ved å formidle et meningsinnhold, eller de kan motsi hverandre. Hver modalitet har potensial til å belyse saken for seg selv, men det at ulike modaliteter samvirker i et helhetlig uttrykk, kan realisere et større meningspotensial.

Arbeid med å lage kunstinstallasjoner innebærer altså multimodal kommunikasjon. Det er et område hvor sosialsemiotikken har en ledende posisjon. Sosialsemiotikken legger vekt på at all kommunikasjon er sosial. Innen sosialsemiotisk språkteori vektlegges både situasjonen, relasjonene som inngår, og hvordan tegnene er satt sammen. Sosialsemiotikken forutsetter altså at både den sosiale konteksten, deltakerne i kommunikasjonen og måten kommunikasjonen skjer på, er nødvendige aspekter for å åpne for kommunikasjonens meningspotensial.

For å tydeliggjøre dette åpnet utstillingen med et seminar som en del av kunstprosjektet. På seminaret presenterte tre flyktninger bosatt på Ål og med ulike religioner seg. De fortalte blant annet om hvorfor de måtte flykte. Videre ble det gjennomført en samtale mellom en religionsviter og meg om verdighetsbegrepet og installasjonen i Ål kyrkje. Innholdet på seminaret ble tatt opp på video, og var planlagt vist i våpenhuset som del av kunstutstillingen.

Fra denne innledningen skal jeg nå presentere nærmere refleksjoner om kunstprosjektet. Først blir det ytterligere fokus på situasjons- og kulturkonteksten, som til sammen utgjør det sosialsemiotikkens grunnlegger Michael Halliday kaller den sosiale konteksten (Halliday, 1978). Så følger refleksjoner rundt fremtredende modaliteter og meningsskapende ressurser. Deretter presenterer jeg eksempler på utforming av samspillet mellom modaliteter, før artikkelen avsluttes med oppsummering og konklusjoner.

\section{Den sosiale konteksten og valg av fremtredende modaliteter}

Konteksten spiller en viktig rolle i kunstprosjekter. Kunstneren Henri Duchamp bidro til å revitalisere kunstens bevissthet om selve 
kontekstens betydning, blant annet i sitt ikoniske verk Fontaine fra 1917. Dette skjedde i et kunstgalleri. Det er en såkalt hvit kube, et nøytralt rom. Hva da med kirkerom? Jeg tror kontekstens betydning er vesentlig sterkere i kirkerom enn i kunstgallerier. Kirkerom rommer i utgangspunktet kompleks og multimodal kommunikasjon med den allerede eksisterende kunsten og interiøret der. Ifølge Halliday er dette en del av den sosiale konteksten og vil spille inn i kommunikasjonen. Dette er det viktig å være seg bevisst. Jeg synes nettopp kirkerom er en egnet sosial kontekst for et kunstprosjekt om verdighet og massemigrasjon. Det henger sammen med det jeg nevnte innledningsvis, at Den norske kirke har ansvar for og innvirkning på verdighet i møte med massemigrasjon. Bevissthet, læring og dannelse er sentralt i den forbindelse. Kirken er en nasjonal aktør som når mange samfunnslag og brukere, også barnehager og skoler.

En viktig side av den sosiale konteksten i Ål kyrkje er de ulike gudstjenester, bryllup, dåper og begravelser som skjer i utstillingsperioden. Kunstutstillingen i Ål kyrkje er også tilknyttet feiringen av reformasjonsjubileet der Martin Luther og begrepet nåde står sentralt. Denne delen av den sosiale konteksten kan vi med Halliday kalle situasjonskonteksten.

Ut fra situasjonskonteksten har jeg utviklet de tematiske faktorene som kunstinstallasjonen handler om. Det er særlig begrepet nåde som er interessant for meg, noe som også kommer til uttrykk i utstillingens og dette kapittelets tittel no mercy no dignity. Nåde er et utfordrende begrep. For hva skjer når den ikke finnes, når det er nådeløst? Og hva skjer når nåden finnes? Det er ikke vanskelig å tenke seg at begge deler kan føre til krenkelser. Å ta imot gaver eller almisser fra en annen kultur eller religion, som man kanskje også ideologisk eller på andre måter er i strid med, kan kjennes krenkende. Det innebærer også utfordringer for Den norske kirke. Jeg ønsker å bidra til at Kirken skal ha bevissthet om temaet, at den skal bidra til at det kan tenkes på nye måter om verdighet, at mennesker kan bli positivt innstilt til endringer når det gjelder bosetting og fordeling av ressurser, og finne nye muligheter for sameksistens på global basis. Dette innebærer massive endringsprosesser. 
En annen side av den sosiale konteksten er kulturkonteksten. Det er den videre konteksten rundt situasjonskonteksten, bygda Ål i Hallingdal, Ål kyrkje og omgivelsene rundt. For å kunne anvende kulturkonteksten bevisst i en kunstinstallasjon, handler det om å orientere seg i Ål. Ål er for eksempel kjent som kulturbygda i Hallingdal. I orienteringene gjelder det å undersøke og reflektere rundt eksisterende uttrykksmåter. Er det for eksempel noen typiske formelementer i kirkerommet som kan benyttes som referanser i kunstinstallasjonen? Det kan bringe kunstinstallasjonen i samspill med konteksten, bidra til gjenkjennelse og åpne for kommunikasjon med mottakerne. Undersøkelser i situasjons- og kulturkonteksten er også viktig for valg av mediering. Valg av mediering handler om å velge uttrykksmåter eller modaliteter til kunstinstallasjonen som passer til temaet og den sosiale situasjonen. I Hallingdal og Ål kyrkje er for eksempel bruk av trematerialet vesentlig.

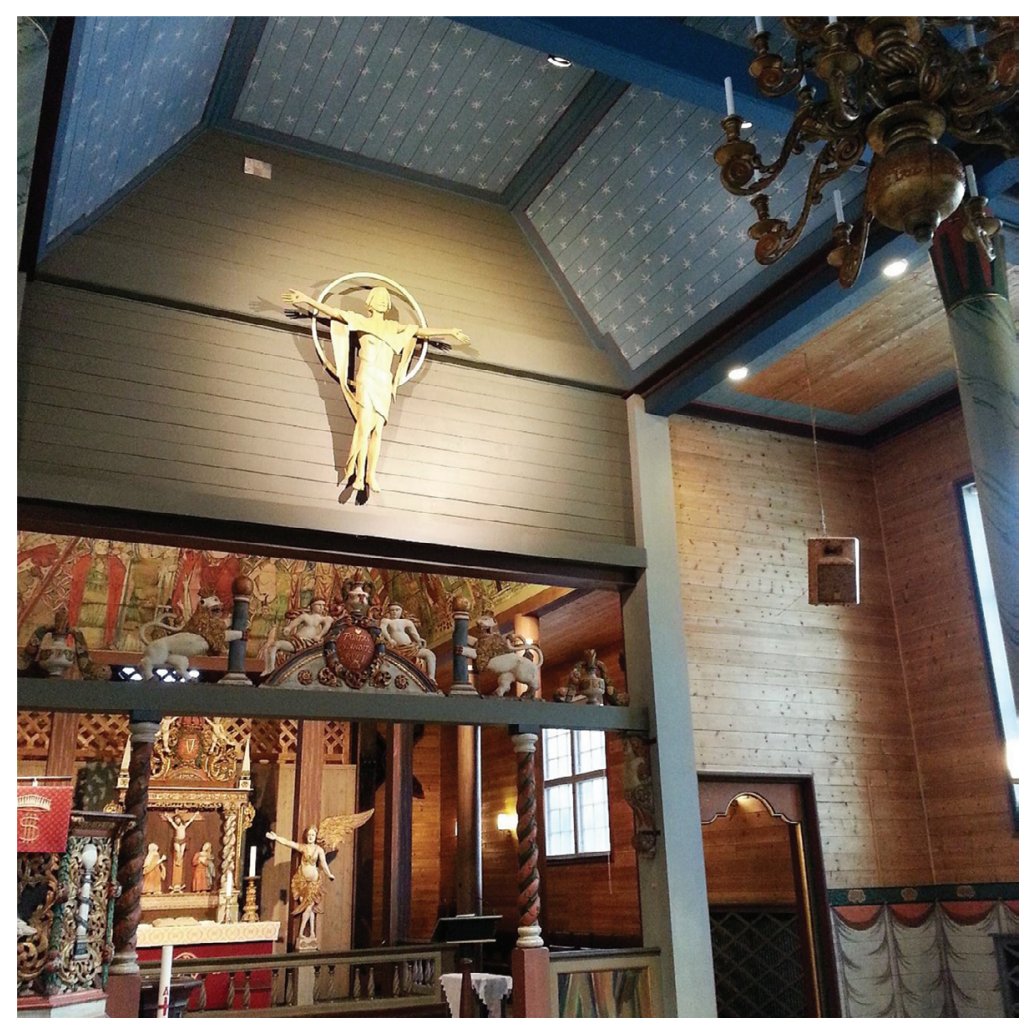

Figur 2. Trematerialet er fremtredende i interiøret i Ål kyrkje, både som konstruksjonsmateriale, som dekor og som kunstneriske uttrykk. (Foto: T. Thorsnes) 
Ål er ei gammel fjellbygd på Østlandet med en lang og stolt tradisjon for arbeid med tre. Trematerialet gir mange referanser i Ål og ikke minst i kirkerommet. Trematerialet kan dermed ha potensial til å kommunisere godt i kunstprosjektet. Tre er brukt som materiale i frie kunstneriske og mer dekorative uttrykk, så vel som i trekonstruksjoner og funksjonelle objekter. Det er derfor gode grunner til å velge trematerialet og konstruksjonsobjekter som fremtredende i kunstinstallasjonen.

Ved siden av trematerialet og konstruksjonsobjekter har jeg valgt skriftlig tekst som den tredje fremtredende modaliteten i dette kunstprosjektet. I Hallingdal er det lang tradisjon for å bruke skriftlig tekst på bygninger og objekter. Skriftlig tekst brukes både med hovedvekt på informasjon, med hovedvekt på dekorasjon og med hovedvekt på kunstnerisk uttrykk.

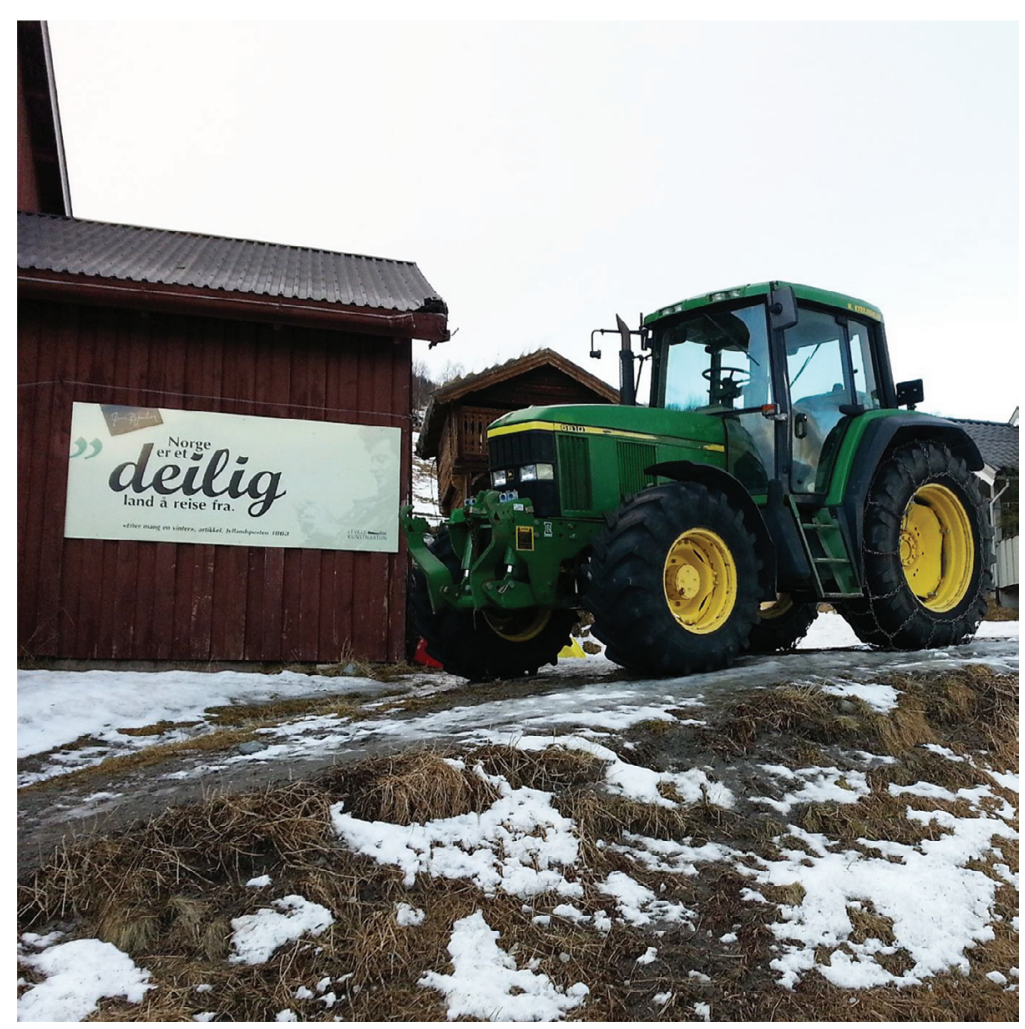

Figur 3. På Leveld i Hallingdal er det nylig gjennomført et kunstprosjekt med tekster fra Jens Bjørneboe på alle eiendommene. Tekstene er velplasserte og iscenesatt til å fungere i samspill med omgivelser og bygninger. I dette tilfellet er det morsomt å legge merke til samspillet mellom teksten, det noe medtatte huset med skade på takskjegget, den glatte snøhålken og traktoren som nærmest står reiseklar. (Foto: T. Thorsnes) 
Befolkningen i Hallingdal er ikke fremmede for uttrykk som kombinerer trematerialet, objekter og skriftlig tekst.

Trematerialet og konstruksjonsobjekter tilbyr opplevelser og erfaringer for både hørsel, syn, lukt og berøring. Berøring er den sansen som gir mest informasjon fra ulike deler av kroppen, fra hud og slimhinner, aller mest fra fingerspisser, ansikt og kjønnsorganer. Menneskelig samhandling med objekter og materialitet er grunnleggende, på samme måte som menneskets iboende verdighet bør være noe grunnleggende. For meg som kunstner blir det et interessant spørsmål om konstruksjonsobjekter og trematerialet kan ha meningspotensial til å sette tanker om verdighet på spill gjennom en kunstinstallasjon i et kirkerom?

Tilsvarende spørsmål har jeg stilt for skriftlige tekster som fremtredende i kunstinstallasjonen. En skriftlig tekst er noe grunnleggende, på samme måte som konstruksjonsobjekter og trematerialet. De bør derfor ha potensial til å samspille godt. Valget av skriftlige tekster er også gjort for å kunne kommunisere med det opprinnelige skriftspråket fra de store verdensreligionene, hinduisme, buddhisme, jødedom, kristendom og islam. Jeg mener det er viktig å bevisstgjøre om religionenes ansvar og innvirkning på verdighet og massemigrasjon i et multikulturelt samfunn. Ved å velge religionenes opprinnelige tekstspråk kan dette tydeliggjøres i kunstinstallasjonen og koble sammen noe opprinnelig og historisk med samtidens utfordringer. Jeg har valgt tre tekster som i kunstinstallasjonen oversettes til de fem religionenes opprinnelige skriftspråk. Tekstene er in transit no borders, no core no fragments og no mercy no dignity. De tre tekstparene er åpne slik at de kan forstås på litt ulike måter som tekst i seg selv. Innholdet i dem vil også endres i samspill med de andre modalitetene, med konteksten og ikke minst med mottakerne. En intensjon med dette er å åpne for undring, refleksjon og samtale blant mottakerne / de besøkende. Tekstene er oversatt til de ulike skriftspråkene av eksperter. De har naturlig nok også hatt spørsmål om hva jeg mener med utsagnene, altså på hvilke måter jeg har tenkt at de skal forstås. De har fått vite det samme som jeg skriver ovenfor.

Halliday anvender tre metafunksjoner som vesentlige i all kommunikasjon, representasjon, interaksjon og komposisjon. I arbeidet med 
kunstinstallasjonen vil jeg undersøke hva konstruksjonsobjektene, trematerialet og de skriftlige tekstene kan representere, hvilke interaksjoner de kan skape, og hvordan de kan komponeres med til temaet verdighet og massemigrasjon. Videre undersøker jeg hvordan de ulike modalitetene i kunstinstallasjonen kan utfylle hverandre og tilby opplevelse, undring, handling, samtale og refleksjon.

I fortsettelsen skal jeg reflektere rundt metafunksjonene til hver av de fremtredende modalitetene. Først presenteres eksempler på representasjon, så interaksjon og så komposisjon. Det fører alt for langt å presentere alle funn og drøfte dem i dette kapittelet, men jeg vil gi noen viktige funn fra de interessante prosessene.

\section{Konstruksjonsobjekter som fremtredende modalitet i kunstinstallasjonen}

Kunstinstallasjonen består av en serie gulvorienterte objekter laget av store, rå askestammer, (se figur 1). Det første objektet har form som en kube. Kuben er en grunnleggende form, akkurat som verdighet er grunnleggende. Kuben har meningsskapende ressurser til å kunne representere noe grunnleggende, noe monumentalt.

De neste objektene i serien endres så med ulike endetapper og plasseres med ca. to meters avstand oppover i midtgangen i Ål kyrkje. De ulike tappene på endene passer i hverandre slik at objektene har potensial til konstruktive overganger, som essensielle, tredimensjonale puslebrikker. Dette kan åpne for assosiasjoner til verdighet og massemigrasjon, både metaforisk og metonymisk.

I avslutningen av midtgangen til kirkeskipet, ved overgangen til korinngangen, ender serien av objekter i en tredelt kuleform/melonform. Denne formen er dreid ut av samme trestamme som de andre objektene, og så splittet på langs til tre like båtformer. Det å avslutte serien av objekter i kunstinstallasjonen med tre likestilte båtformer kan assosieres til reise og frihet, likhet og brorskap, som igjen kan ha egenskaper til å representere massemigrasjon og verdighet. I samspill med skriftlig tekst kan representasjonen utdypes og forsterkes. 


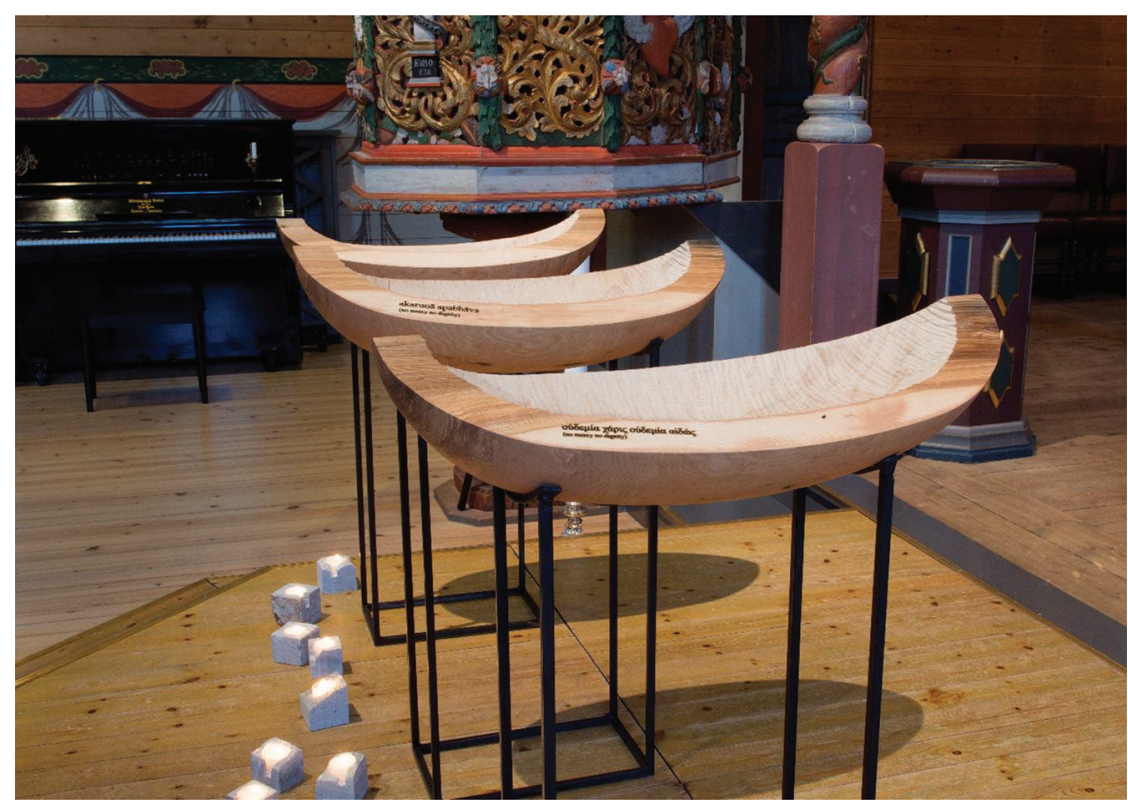

Figur 4. Fotografiet viser båtobjektene med teksten no mercy no dignity påført. (Foto: T. Thorsnes)

Jeg skal nå reflektere rundt noen eksempler på interaksjon som konstruksjonsobjekter kan ha meningspotensial til å åpne opp for. Konstruksjonsobjekter kan skape referanser til bygningskonstruksjoner, båtkonstruksjoner og til konstruksjoner i ting. I utformingen av konstruksjonsobjektene har jeg for eksempel brukt tydelige referanser til dørene i kirken på Ål.

Utover dette kan konstruksjonsobjektene invitere til interaksjon gjennom ulike handlinger, som å ta på, sitte på og klatre på. Slike referensielle og taktile funksjoner er viktige meningsskapende ressurser knyttet det å være menneske, å bygge, å reise, å spise, osv.

Konstruksjonsobjektene har også komposisjonelle meningsskapende ressurser til å belyse verdighet og massemigrasjon. Objektene lages ut av store rå askestammer, har stort volum og tar fysisk mye plass i et rom. Kunstinstallasjonen vil ta stor plass og være sentralt og kanskje noe påtrengende eller forstyrrende plassert. Har noe fătt sentral plassering, tar mye plass, er påtrengende og forstyrrende, da kan det ha potensial til å forløse assosiasjoner til at det er noe viktig, noe grunnleggende og presserende som blir tematisert. Det passer godt til verdighet og massemigrasjon. 

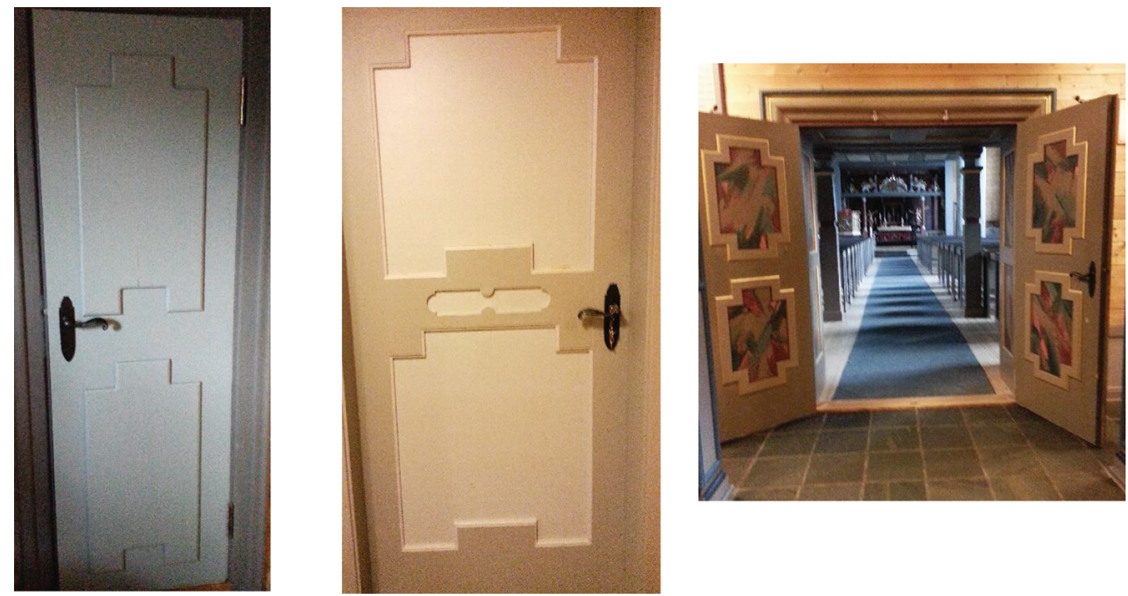

Figur 5. Fotografiene viser noen av dørene i kirken på Ål. De konstruksjonsobjektene jeg har laget, er nærmest tredimensjonale varianter av flatene vi ser som former i dørfyllingene. (Foto: T. Thorsnes)

\section{Trematerialet som fremtredende modalitet $\mathbf{i}$ kunstinstallasjonen}

Trær er noe grunnleggende og levende, en livsbetingelse, noe også verdighet er. Trær finnes i ulike størrelser, farger og former og er grenseløse. De lever og vokser nær sagt over hele verden og innvirker på hele verden. Treet er ustyrlig selv etter at det er hugget ned, akkurat som individet kjører sitt eget liv. Treet har potensial til å kunne representere mennesket.

Trær lagrer informasjon om klimaet, og forskere kan analysere trær og tolke klimaendringer. Trær lever en perfekt naturlig syklus ved fotosyntesen. Verdens klima påvirkes negativt hvis regnskog blir hugget ned. Klimaendringene er en av årsakene til massemigrasjon. Treet har på den måten muligheter til å kunne representere klimaendringer og derved gi assosiasjoner til massemigrasjon. Selve trestammen med marg og årringene som bygger seg på, kan assosieres til tid og levd liv. Tresprekker, sår etter avbrukne grener og små årringer etter tøffe år kan i en relevant kontekst fungere som meningsskapende ressurser i kunstneriske uttrykk om verdighet og massemigrasjon.

Fra treets mulige representative egenskaper vedrørende verdighet og massemigrasjon skal jeg nå presentere eksempler på treets potensial til interaksjon. 
Trær brukes som symbol i mange forskjellige sammenhenger, spesielt i myter og religioner. Ask, som brukes her, har mange referanser. Ask er for eksempel navnet på den første mannen, ifølge skapelsesberetninger fra norrøn mytologi. Trær har forskjellige farger, overflater, hardheter, strukturer, grener og kvister, sprekker og årringer. Det stimulerer vår synssans og vår lydsans, alt fra skogens sus til alle de fantastiske instrumenter som er laget av tre. Trematerialet innbyr til interaktivitet som det å lukte og ikke minst berøre. Taktilitet er en av våre sterkeste sanser. Nyere forskning viser at informasjon gjennom håndflaten og fingrene er en sans som ikke avtar med alderen. Syns-, lyd-, duft- og berøringskontakten med trematerialet bidrar til å holde positiv kontakt med naturen. Det kan øke bevisstheten om mulige klimaendringer og derved om massemigrasjon og verdighet.

Trær lever videre etter at det er hugget ned, det tørker, krymper og beveger seg etter luftens fuktighet. Slike formendringer kan skape undring, samtale og refleksjon. Det gir kontakt med naturen og interaksjon med materialitet, og kan tenkes som meningsskapende ressurser tilknyttet klimaendringer.

Jeg skal nå presentere eksempler på muligheter til å komponere med trematerialet. Trær kan formes og komponeres med både gjennom hugging og konstruksjon, gjennom organiske og geometriske former, og kombinasjoner av dette.

I kunstinstallasjonen brukes som nevnt hele trestammer med marg og kjerne som utgangspunkt for å lage konstruksjonsobjekter. Det kan gjøres ulike inngrep i materialet, og det kan behandles på forskjellige måter. Årringer, sprekker, tørkebevegelser, kvister, blankhet, ruhet, osv. er uttrykksmuligheter og mulige meningsskapende ressurser i materialet. I en kube laget av en trestamme blir rotskuddet og margen synlig i tverrsnittet. Det samme gjelder kjerne- og yteveden og årene som bygger seg på. Årringene forteller om gode og dårlige år. Hvert tre er unikt, det er ustyrlig og har egenrådighet, akkurat som menneskets iboende verdighet bør være. Selv om treet tørker og sprekker, så å si får sår og sprekker i fasaden, lever det videre selv etter at det er hugget i. Treet kan altså ha potensial til å representere noe menneskelig i forbindelse med massemigrasjon og verdighet.

Ved å lage kutt inn til margen på stokkene kan det oppnås noe kontroll på sprekkdannelser under tørkeprosessen. Treet krymper under tørking 
og kuttet forløser krefter i trecellene, slik at det er den oppkuttede sprekken som utvider seg mest. Det er ikke slik at dette bare kontrollerer sprekkenes uttrykk noe, men objektenes form endrer seg også under tørkingen, fordi cellene krymper. Den i utgangspunktet stramme geometriske formen tørker, slik at det skapes en formendring. Dette kan gi et mer levende uttrykk, som mennesket som kjører sitt eget liv. Formendringene og sprekkene kan også ha potensial til å uttrykke at verdighet ikke bare handler om noe grunnleggende, men også noe levende og dynamisk. Spenningene og spillet er så sterkt at fasaden sprekker, og formen endrer seg.

Hele komposisjonen peker billedlig på noe byggende og noe som skalvirke sammen, som konstruksjonsobjekter i et byggverk. Det er konstruksjonene som avgjør byggets slitestyrke. Dette kan billedlig brukes som komposisjonelle meningsskapende ressurser både til verdighet og massemigrasjon.

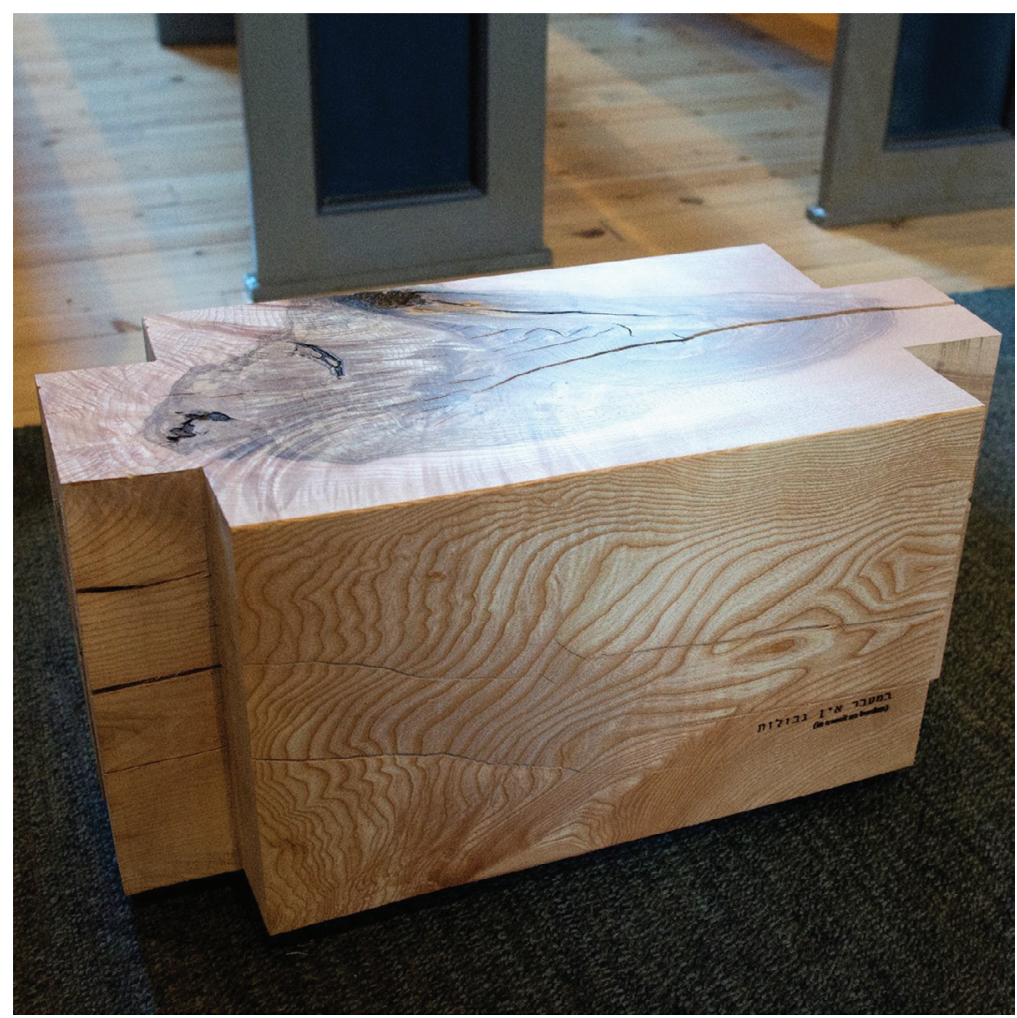

Figur 6. Fotografiet viser hvordan et av konstruksjonsobjektene har levd liv i seg, og hvordan det kan komponeres med sprekker og formendringer. Legg også merke til komposisjonens konstruktive elementer med endetappene. (Foto: T. Thorsnes) 


\section{Skriftlig tekst som fremtredende modalitet $i$ kunstinstallasjonen}

Skriftlig tekst kan være en formell og grunnleggende uttrykksmåte. Jeg har laget tre skriftlige tekstpar som på ulike måter berører verdighet, massemigrasjon og klimaendringer. Det er tekstparene: no mercy no dignity (ingen nåde ingen verdighet), in transit no borders (i transitt ingen grenser) og no core no fragments (ingen kjerne ingen fragmenter). Begrepsparene er konkrete, men samtidig assosiative. I kunstinstallasjonen skal tekstene påføres de forskjellige objektene. Tekstene kan, på samme måte som trematerialet og konstruksjonsobjekter, formes på mange ulike måter. Det gjelder for eksempel valg av språk, hvor teksten blir plassert på objektene, og hvilken teksttype og skriftstørrelse som fremstilles.

Det vil føre for langt å gi eksempler på meningsskapende ressurser i de tre metafunksjonene for alle tekstparene. For å presentere svar til problemstillingene i dette kapittelet, har jeg derfor valgt én av tekstene som eksempel: in transit no borders.

Jeg skal først reflektere rundt in transit no borders' representative meningspotensial. In transit betyr at noe er underveis over landegrenser. No borders betyr uten grenser. Utsagnet kan representere og gi assosiasjoner til at mennesker som er underveis som følge av massemigrasjon, ikke skal holdes tilbake av landegrenser.

Et viktig aspekt ved de skriftlige tekstene er, som nevnt, hvilke språk som velges. Det er mange språk å velge mellom for eksempel FNs offisielle språk, eller samtidens verdensspråk, eller det noen mener ettertiden vil vurdere som 2000-tallets verdensspråk. Det er også interessant å tenke språk ut fra innbyggerne på Ål, som består av en stor del ulike nasjonaliteter i tillegg til den etnisk norske befolkningen. For mange av de nye innbyggerne, er arabisk og tigrinja kjente språk.

I tillegg til disse mulige inngangene for valg av språk, er det også relevant å tenke på ulike liturgiske språk, for eksempel ut fra de store verdensreligionene, jødedom, buddhisme, hinduisme, islam og kristendom. Jeg ønsker som nevnt å bidra til at verdensreligionene ser at de har ansvar for og innvirkning på verdighet og massemigrasjon, og jeg ønsker dialog om verdighet og massemigrasjon mellom religionene. I kunstinstallasjonen vektlegger jeg derfor at språkene kan oppfattes noe fristilt fra tid og 
rom, at de kan representere en slags tidløs aktualitet. På den bakgrunn er de gamle skriftspråkene til verdensreligionene relevante, dvs. sanskrit for hinduismen, pali for buddhismen, hebraisk for det gamle testamentet i Bibelen (jødedom og kristendom), gammelgresk for Det nye testamentet (kristendom) og arabisk for islam. Jeg har derfor valgt disse språkene som mest representative i kunstinstallasjonen.

Jeg skal nå presentere et eksempel på in transit no borders' meningspotensial tilknyttet interaksjon. In transit no borders er et uttrykk som vanligvis benyttes til reise over landegrenser. Utsagnet tilbyr referensielle og intertekstuelle meningsskapende ressurser i kunstinstallasjonen. For mottakere som er kjente med eller nærmere interessert i begrepene, vil for eksempel søk på internett gi informasjon om prosjekter som både kunstnere, arkitekter og andre arbeider med for å bidra til verdighet $\mathrm{i}$ møte med massemigrasjon.

In transit no borders har også komposisjonelle meningsskapende ressurser tilknyttet verdighet og massemigrasjon. Som nevnt er det aktuelt å bruke de opprinnelige skriftspråkene til verdensreligionene, med en tilhørende oversettelse på engelsk. Jeg har valgt å komponere med de opprinnelige språkene i størst skriftstørrelse. Det er de tekstene som først

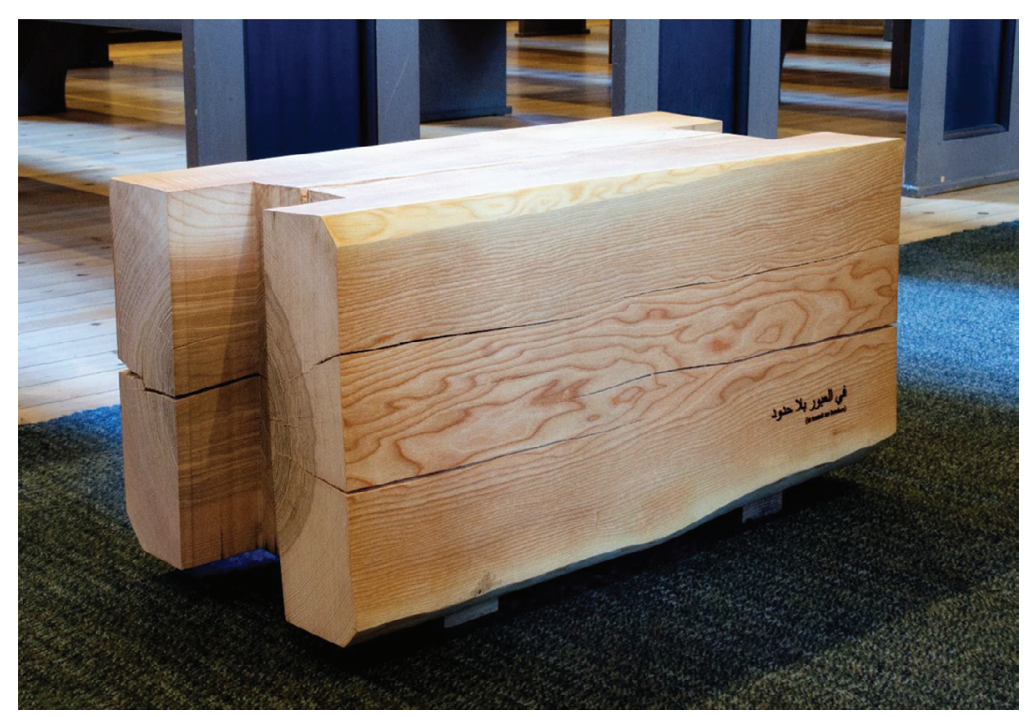

Figur 7. Fotografiet viser påført tekst in transit no borders på et konstruktivt objekt med en av religionenes opprinnelige skriftspråk, nemlig arabisk. Den engelske oversettelsen er påført i mindre typer og nøytral form. (Foto: T. Thorsnes) 
og fremst skal være fremtredende i uttrykket. Den engelske oversettelsen komponeres i mindre størrelse og med anonym teksttype/font. Uten en slik oversettelse ville mye av det tenkte meningspotensialet kunne forsvinne, i og med at det er få som kjenner de opprinnelige skriftspråkene.

\section{Samspill mellom modalitetene i kunstinstallasjonen}

I den skapende prosessen med å kombinere de fremtredende modalitetene til et bevisst samspill, tilbyr sosialsemiotikken også her å tenke meningspotensial i kunstinstallasjonen ut fra begrepene representasjon, interaksjon og komposisjon. Det er en spennende prosess å vurdere hva slags meningspotensial om verdighet og massemigrasjon som kan ligge i samspillet mellom materialet, objektets form og skriftlig tekst i hvert enkelt objekt, i samspillet mellom de ulike objektene i serien, og i objektenes samspill med hele rommet. Det gjelder for eksempel å vurdere ut fra representasjon, interaksjon og komposisjon hvor store og hvor mange objekter det kan det være i serien, og hvor og hvordan de skal plasseres og samspille.

Kunstinstallasjonen består som kjent av en serie med objekter i midtgangen i Ål kyrkje, med kuben som første objekt. I det første objektet innpreges teksten no core no fragments på de fem opprinnelige skriftspråkene. I de fem konstruksjonsobjektene videre oppover i midtgangen innpreges teksten in transit no borders, oversatt til hvert av de religiøse skriftspråkene. Ett språk er representert på hvert sitt objekt. I de tre båtformene på trappen opp til koret påføres teksten no mercy no dignity. Disse valgene er tenkt som meningsskapende, slik at tekstene og objektenes form kan samvirke med bevegelsen/retningen i rommet. Helt konkret forsøker jeg å skape en meningsutvikling i serien av objekter, som igjen kan samspille med bevegelsen i kirkerommet. Det er for eksempel helt bevisst at installasjonen avsluttes i kirkeskipet, og ikke ender inne i selv koret. Kirkeskipet er et mer nøytralt rom enn koret og peker på det å være sammen på reise.

Michael O'Toole har bidratt med nyere sosialsemiotisk multimodalitetsteori. I introduksjonen til boken The language of displayed art (1994) fremhever O’Toole at semiotisk orienterte tilnærminger tilbyr et felles 
språk som gjør det mulig å skape meningsfulle dialoger om kunst og kultur (O’Toole, 1994, s. 4). I samme boken presenterer O’Toole (1994, s. 85-86) hvordan det går an å zoome inn på enkelte deler av en kommunikasjon, og for eksempel analysere samspillet mellom figur og materiale i en skulptur.

På samme måte er det interessant å kunne se nærmere på et avgrenset område av den skapende prosessen. Med utgangspunkt i teori fra O’Toole skal jeg nå zoome inn på noen viktige valg for det kunstneriske uttrykket og multimodalt samspillmellom skriftlig tekst og konstruksjonsobjektene. Det kan være at det skal uttrykkes noe spesielt viktig eller sentralt i enkelte deler av kommunikasjonen. I dette tilfellet gjelder det forholdet mellom konstruksjonsobjektene, valg og utforming av tekst.

Det vil føre for langt i dette kapittelet å redegjøre for både representasjon, interaksjon og komposisjon på alle objektene i installasjonen. Jeg har derfor valgt å reflektere rundt det komposisjonelle samspillet i et konstruksjonsobjekt med en av de skriftlige tekstene.

\section{Det komposisjonsmessige samspillet mellom konstruksjonsobjekter og skriftlig tekst}

Det jeg nå skal zoome inn på, innebærer en komposisjonsmessig utforskning for å oppnå at tekstene integreres med objektene. Et integrert objekt- og tekstuttrykk innebærer at det multimodale samspillet ses som en helhet, at de enkelte modalitetene trer frem som deler i en helhet. For å kunne oppnå dette er tekstenes plassering og størrelse de mest vesentlige meningsskapende ressursene. I fortsettelsen skal vi se nærmere på dette gjennom et objekt og en skriftlig tekst, nemlig kubeformen og teksten no core no fragments.

Det utgjør en tor forskjell på det multimodale uttrykket om no core no fragments tar stor eller liten plass på objektets sideflater. Hvis den tilførte teksten fyller hele flaten, kan det medføre at objektet og materialet underkastes teksten og blir et underlag, en bakgrunn. Hvis den tilførte teksten er middels stor og utfyller ca. halve flaten på en side av objektet, er teksten veldig lesbar, og vil stadig kunne være den dominerende modaliteten. Hvis den tilførte teksten proporsjonsmessig tar liten plass på en sideflate, vil mottakerne kunne se helheten først, formen og materialet, og deretter 
oppdage teksten. Det er en slik inngang jeg ønsker at mottakerne skal ha til kunstinstallasjonen. Kunstinstallasjonen skal ha hovedvekt på det visuelle, og så kunne åpne for de meningsskapende ressursene som både form, materialitet og skriftlig tekst kan ha, alene og i samspill.

Fra dette valget av liten størrelse på den skriftlige teksten zoomer jeg videre inn på valg av hvor på sideflatene den skriftlige teksten plasseres. En midtstilt og sentrert tekst gir et annet uttrykk enn om teksten er toppstilt eller bunnstilt. En midtstilt og sentrert tekst for alle språkene gir lite visuell spenning. Det gir også liten mulighet for nyansering mellom språkene. Enkelte av språkene leses for eksempel fra høyre, og andre språk fra venstre, noe det ut fra temaet verdighet kan være fint å presentere slik det er vanlig.

En toppstilt tekst vil kunne tiltrekke seg mye oppmerksomhet, selv om den rent proporsjonsmessig vil utgjøre en liten del av flaten. En bunnstilt tekst vil kunne oppfattes som beskjeden, en tekst som oppfattes etter formen og materialet. Det vil kunne, for dem som er vant til å se kunst og signerte verk, i første omgang kunne oppfattes som en signatur. Signaturer kan assosieres med noe svært betydningsfullt, i mange sammenhenger er det signaturen som bekrefter og gir gyldighet. Slike assosiasjoner passer godt til temaet verdighet og massemigrasjon. Tenk bare på hva et gyldig signert pass eller en underskrift på en reisetillatelse kan gjøre! Jeg velger derfor en slik plassering og et slikt samspill mellom objektets form og de skriftlige tekstene.

\section{Avslutning, oppsummering og konklusjoner}

Samlet sett er det grunn til å fastslå at den multimodale prosessen med å skape kunstinstallasjonen er kompleks og dynamisk. Det pågår en kontinuerlig veksling mellom å se helhet og deler i sammenheng med den sosiale konteksten. Et valg i én modalitet påvirker de meningsskapende ressursene i de andre modalitetene. I et kirkerom er det mange modaliteter som virker i kommunikasjonen. Det kan derfor være lett å miste oversikt og kontroll over de meningsskapende ressursene, og derved det multimodale uttrykket/kunstinstallasjonen.

Sosialsemiotikken og multimodalitetsteoriene tilbyr den som skaper, muligheten til å analysere den sosiale konteksten og ut fra dette velge 
referanser og mediering/valg av fremtredende modaliteter. Sosialsemiotisk teori, som vanligvis benyttes til analyse, fungerer godt som tankeknagger underveis i prosessene med å skape kunstinstallasjonen. Det samme gjelder for helheten i kommunikasjonen, som består både av den sosiale konteksten, av temaet kommunikasjonen handler om, av de enkelte delene i det multimodale uttrykket, samspillet mellom dem og av mottakerne som deltakere. Jeg har funnet stor nytte i det sosialsemiotiske rammeverket og har brukt det bevisst til å skape en kunstinstallasjon med et åpent verdighetsbegrep til temaet massemigrasjon.

Når det gjelder den åpne forståelsen av verdighet som ligger til grunn for dette kunstprosjektet, og det å kunne kommunisere dialogisk, har det sosialsemiotiske rammeverket åpnet opp for dette. For når den som skaper, kan kommunisere ut fra et tenkt meningspotensial og forutsette at mottakeren er en deltaker som ut fra sitt ståsted og sin kultur opplever og tenker sitt, så kan det kanskje virke frigjørende fra lite hensiktsmessige eller fastlåste deltakerroller. Sosialsemiotikkens rammeverk har fungert godt til å lage en utstilling/hendelse med seminar og kunstinstallasjon basert på et åpent verdighetsbegrep. Det kan antyde at andre institusjoner, som skoler og barnehager, vil kunne dra nytte av det sosialsemiotiske rammeverket i sin tilrettelegging for læring og dannelse tilknyttet temaet massemigrasjon og verdighet.

Et viktig aspekt ved det å skape kunstneriske uttrykk er tanken om at kunstverk skal kunne stå selvstendig. En viktig oppgave for kunsten er å stille og aktualisere spørsmål, uten noen forklaring eller tolkning fra kunstneren. For kunstnere er det likevel ofte nødvendig å fortelle om hva han eller hun har tenkt om og ment med verket, eller lignende. Det kan også oppstå spørsmål som fører kunstneren inn i en ordlegging som gjør verket platt, eller rett ut sagt, ødelegger det for mottakeren. Alle som skaper kommunikasjon, har behov for et metaspråk, begreper å tenke og uttrykke seg ut fra. Sosialsemiotikkens rammeverk har fungert godt til å reflektere over hva jeg ut fra metafunksjonene vil si at materialet, objektene og tekstene kan uttrykke, hver for seg og i samspill. Men metafunksjonene har også fungert som tankeknagger til hva jeg ikke vil si. Og det er kanskje vel så viktig, ikke bare for kunstneren, men for alle som arbeider med dialogisk kommunikasjon? 


\section{Forfatteromtale}

Tollef Thorsnes (f. 1965) arbeider som dosent i kunst og håndverk på Universitetet i Sørøst-Norge. Han arbeider også som kunstner og har kirkerom og kirkekunst som et av sine interessefelt. Over mange år har Thorsnes både arbeidet med utsmykningsoppdrag i kirker og jevnlig hatt temporære utstillinger i ulike kirker og kirkerom. Ved siden av arbeidet som kunstner er Thorsnes også forsker og forfatter. Han har skrevet flere fagbøker og publisert en rekke artikler.

\section{Referanser}

Kress, G. \& van Leeuwen, T. (1996). Reading images: the grammar of visual design. London: Routledge.

Kress, G. \& van Leeuwen, T. (2001). Multimodal discourse: the modes and media of contemporary communication. London: Arnold.

Halliday, M. A. K. (1978). Language as social semiotic: the social interpretation of language and meaning. London: Edward Arnold.

Maagerø, E. \& Veum, A. (2013). Svend Foyn. Meaning potentials of monument and space. RASK Internationalt tidsskrift for sprog og kommunikation, 39/2013, 67-98.

McCrudden, C. (2014). The Pluralism of Human Rights Adjudication. I L. Lazarus, C. McCrudden, \& N. Bowles (Red.), Reasoning Rights; Comparative Judicial Engagement. Oxford and Portland; Oregon: Hart Publishing.

O’Toole, M. (1994). The language of displayed art. Rutherford: Fairleigh Dickinson University Press.

Riley, H. (2013). Visual art and social structure: the social semiotics of relational art. Visual communication 12(2), 207-216.

van Leeuwen, T. (2005). Introducing social semiotics. London: Routledge. 



\title{
KAPITTEL 8
}

\section{Verdighet og selvbestemmelse- En aktørbasert forestilling om menneskeverdet}

\author{
Sven Arntzen
}

\section{Universitetet i Sørøst-Norge}

\begin{abstract}
Dignity, according to one conception, is the absolute, inherent and inalienable value of every person. There is general agreement that this idea of dignity has a source in Immanuel Kant's moral philosophy. I argue that Kant formulates what I characterize as an agency or agent based conception of dignity. Persons are bearers of dignity in their capacity as moral subjects and subjects of action. Central here is the idea that a rational agent is the subject of "any end whatsoever" and so must be considered the free cause of actions. Accordingly, to be treated merely as a thing, or "as a means", is to be treated in a manner incompatible with having and acting for the sake of any end of one's choosing. Also relevant in this connection is Alan Gewirth's agency based theories of dignity and of human rights.

I then consider this conception of dignity in addressing three ethical issues: to let die or keep alive, assisted suicide, and so-called $d$ warf-tossing. Finally, I consider challenges to the idea of dignity in general and the agency based conception of dignity in particular.
\end{abstract}

Keywords: Dignity, inherent value, Kant, Gewirth, agency, autonomy, self-determination, human rights

\section{Innledning}

Ordet «verdighet» blir brukt i ulike betydninger. Man snakker for eksempel om å «bevare verdighet» (f.eks. Brock, 1992, s. 11), som om verdighet er noe som kan forspilles, og om personers «rett til verdighet» (f.eks. Barak, 2013, s. 367-68), som om verdighet er noe en person ikke nødvendigvis er i besittelse av. Men i den betydningen som jeg skal drøfte i dette kapitlet, er

Sitering av denne artikkelen: Arntzen, S. (2019). Verdighet og selvbestemmelse - En aktørbasert forestilling om menneskeverdet. I Å. Valen-Sendstad \& I. R. Christensen (Red.), Menneskeverd - en utfordring for skole og samfunn (Kap. 8, s. 191-213). Oslo: Cappelen Damm Akademisk. https://doi.org/10.23865/ noasp.90.ch8. 
verdighet å forstå som iboende verdi, som noe absolutt, noe ubetinget, ufravikelig og uavhendelig som tilkommer enhver person. I denne betydning er verdighet noe man nødvendigvis er i besittelse av, uavhengig av atferd og handling: «[i]kke engang en morder forspiller sin personlige verdighet.» (Johannes Paulus II, 1995) Vår tids tanke om menneskeverdet er en individualistisk tanke. Det er enkeltpersoner som er innehavere av verdighet.

For tanken om menneskeverdet $\mathrm{i}$ denne betydningen er det $\mathrm{i}$ hovedsak to konkurrerende tilnærmelser. Den ene knytter verdighet til det å være menneske, det særegne ved mennesket som skiller det fra dyr. For denne tilnærmelsen er et eksisterende menneske og et menneskeliv hellig, noe som skal bevares til enhver pris. I én variant knyttes denne tilnærmelsen til den bibelske tanken om at Gud har skapt det levende mennesket i sitt bilde (1. Mos. I 26-27, II 7). Forestillingen om verdighet ifølge en slik tilnærmelse er blitt brukt i argumentasjon mot dødsstraff av den amerikanske høyesterettsdommeren William J. Brennan, Jr.: «Sammenlignet med alle andre typer straff $\mathrm{i}$ våre dager ... er statens utslettelse av et menneskes liv uten sidestykke en krenkelse av menneskelig verdighet.»

Den andre tilnærmelsen knytter menneskets verdighet til «autonomi» forstått som evnen til å være selvbestemmende i valg og handling (f.eks. Dupré, 2012, s. 271). Innehaver av verdighet er den som selv kan velge sine formål og handlinger uavhengig av andres påvirkning eller tvang. Det er en utbredt oppfatning at denne tanken om verdighet har sitt opphav i Immanuel Kants (1724-1804) moralfilosofi (f.eks. Saugstad, 2001, s. 120-121).

I dette kapitlet vil jeg, med grunnlag i Kants tanke om verdighet, fremstille en aktørbasert forestilling om menneskeverdet. Også relevant er Alan Gewirths argumentasjon om at mennesket som aktør har iboende verdighet og grunnleggende rettigheter. Det er først og fremst som et moralens og handlingens subjekt at en person er innehaver av verdighet. En slik forutsetning for forestillingen om verdighet har bestemte etiske implikasjoner som jeg vil belyse med problemstillingene: å holde i live eller la dø, aktiv dødshjelp, kasting av kortvokste personer for sport og underholdning («dwarf-tossing»). Og jeg vil drøfte utfordringer mot tanken om menneskets iboende verdighet.

1 Tilslutning til den amerikanske høyesteretts dom i Furman v. Georgia (1972), der flertallet avviste bruk av dødsstraff som «cruel and unusual punishment». 


\section{Verdighet, autonomi, selvbestemmelse}

For Kant er verdighet («Würde») en type verdi «som er hevet over enhver pris» (Kant, 1983, s. 51 [4:434]). Pris er en erstattelig, målbar og graderbar verdi, en verdi som er betinget av behov, ønsker eller smak. Til denne type verdi hører også instrumentelle goder, verdier som lar seg gradere som mer eller mindre nyttige. Verdighet, derimot, er en absolutt, uerstattelig og uavhendelig verdi, en type verdi som ikke lar seg gradere, og heller ikke kan måles (Kant, 1991, s. 231, 254 [6:436, 462]).

Kant knytter sin bruk av ordet verdighet til tanken om det han kaller menneskelighet, blant annet når han sier: «Menneskeligheten [«die Menschheit»] selv er en verdighet» (Kant, 1991, s. 255 [6:462]). Med ordet «Menschheit» sikter Kant til noe annet og mer enn bare menneskearten eller medlemskap i denne. Ordet har en moralsk betydning og er derfor bedre gjengitt med «menneskelighet» enn med «menneskehet». (f.eks. Ranheim, 2016, s. 80) Menneskelighet er «fornuftig natur» (Kant, 1983, s. 55 [4:439]). Å være i besittelse av verdighet er å eksistere som formål i seg selv, og det er bare menneskelighet som kan tenkes å være formål i seg selv (Kant, 1983, s. 45 [4:428]). Kant skjelner mellom subjektive og objektive formål (Kant, 1983, s. 45 [4:427]). Et subjektivt formål er den tilsiktede virkning en person søker å realisere gjennom handling, som regel ut fra egne behov og ønsker. Man kan for eksempel ha egen rikdom som sitt formål og foreta de handlinger man mener er best egnet som middel til å realisere dette formålet. Et bestemt subjektivt formål er ikke et formål alle nødvendigvis har. Et objektivt formål er gitt uavhengig av personers behov eller ønsker. Ethvert formål har verdi. Et subjektivt formåls verdi er betinget av at det faktisk er valgt av en person. Et objektivt formåls verdi er ubetinget, absolutt. Bare et formål i seg selv er et objektivt formål, for det er «ikke noe som skal frembringes, men et selvstendig [eksisterende] formål» (Kant, 1983, s. 53 [4:437]). Ethvert formål er handlingsbegrensende. Frembringelsen av et subjektivt formål forutsetter en bestemt handling eller et avgrenset omfang av mulige handlinger, til utelukkelse av visse andre handlinger. Under normale omstendigheter gir man for eksempel ikke bort alt man har hvis formålet med handling er å bli rik. Slikt sett er et formål bestemmende for de handlingsvalg man gjør. Et objektivt formål, gitt av fornuften, skal 
være bestemmende for valg og handling overhodet, uavhengig av den enkeltes preferanser.

Kant knytter verdighet til det å være moralsk subjekt. Det er som evne til moral at menneskelighet har verdighet (Kant, 1983, s. 51 [4:435]). Verdighet er noe en person har i kraft av autonomi: «Autonomi er ... grunnen til den menneskelige og enhver fornuftig naturs verdighet.» (Kant, 1983, S. 52 [4:436]) «Autonomi» i den egentlige betydning av ordet, etter de greske ordene auto (selv) og nomos (lov), har å gjøre med egen lov eller selvlovgivning. Det er i denne betydningen Kant bruker ordet. Autonomi er for ham den enkeltes evne eller kapasitet til å bestemme seg selv i valg og handling i henhold til fornuftens moralske lovgivning, en lovgivning man selv er delaktig i som fornuftig vesen, uavhengig av og til og med i motsetning til egne behov eller ønsker. Man har skjelnet mellom to komponenter ved autonomi for Kant (Schneewind, 1992, s. 309): (1) enhver kan selv erkjenne fornuftens moralske lover og de krav som ligger i dem, og (2) den enkelte kan ved sin fornuft effektivt kontrollere seg selv og «tvinge» seg selv til å handle i samsvar med fornuftens lover. Det er bare under forutsetning av autonomi i slik forstand at en person kan være underlagt moralsk forpliktelse, som ifølge Kant er unntaksløs, og som dermed forutsetter den enkeltes evne til valg og handling uavhengig av egne ønsker eller behov. Autonomi i denne betydning er ikke det samme som «autonomi» i tidligere nevnte betydning av evne til selvbestemmelse (jf. Saugstad, 2001, s. 124-25). For evnen til å bestemme over seg selv i valg og handling er det tilstrekkelig at man kan handle ut fra egne preferanser i fravær av andres inngrep eller mentale eller fysiske begrensninger. Når verdighet knyttes til evne til selvbestemmelse, er ikke dette uten videre det samme som å knytte verdighet til autonomi i Kants betydning.

Men også for Kant er det en kobling mellom verdighet og evne til selvbestemmelse i valg og handling. Han karakteriserer menneskelighet som «evnen til overhodet å sette et hvilket som helst formål ... (til forskjell fra dyrene)» (Kant, 1991, s. 195 [6:392]). Det som eksisterer som formål i seg selv, må selv være «subjektet for alle mulige formål» (Kant, 1983, s. 53 [4:437]). Det finnes ingen på forhånd bestemte formål som en person nødvendigvis har, og som driver ham eller henne til bestemte typer handling. Kant går ut fra at et enhver bevisst eller overveid handling har et formål. 
Å være subjekt for alle mulige formål er en forutsetning for moralsk forpliktelse. Det å kunne ha eller sette seg et utall eller hvilket som helst formål omfatter evnen til å rette seg etter et objektivt formål og dermed sette til side subjektive formål, som har utspring i egne behov og ønsker. Dette er et nødvendig element ved autonomi. Samtidig er det en nødvendig betingelse for den enkeltes selvbestemmelse i valg og handling. Et formål er per definisjon gjenstand for fritt valg (Kant, 1991, s. 186-187 [6:381]). Den som foretar en bestemt handling i henhold til eget valg, uavhengig av andres press eller tvang og av naturens mekaniske lover, er det Kant kaller handlingens «opphav», dens «frie årsak» (causa libera) (Kant, 1991, s. 50, 53 [6:223, 227]). Her er et sentralt kriterium for skillet mellom person og ting. En ting er bestemt utelukkende av ytre årsaker, i samsvar med naturens mekaniske lovmessighet. Billiardkulen er ikke selv årsak til egen bevegelse; dominobrikken er ikke selv årsak til at den velter. En ting er utelukkende objekt, noe det skjer noe med, som beveges av noe annet enn seg selv. En person er subjekt, den som gjør noe, som handler ut fra seg selv. Mens et objekt er det som reagerer, er det en sentral tanke hos Kant at et subjekt agerer (jf. Korsgaard, 1996, s. 363). For enhver handling kunne en person som mulig subjekt for et utall formål og som handlingers frie årsak ha valgt å handle annerledes. Den som foretar handlingen, gjerningspersonen, kan stilles til ansvar for det han gjør.

For Kant er verdighet primært knyttet til autonomi. Samtidig må verdighet for ham også være knyttet til evne til selvbestemmelse i valg og handling, siden autonomi er en forutsetning for å være handlingers subjekt. Så verdighet knyttet til personen som moralsk subjekt kan gjøres gjeldende mer generelt for personen som subjekt for handling. Verdighet er en type uavhendelig verdi personen er i besittelse av som aktør, som handlingers subjekt på godt og ondt. Kant har en aktørbasert forestilling om verdighet.

\section{Hensynet til verdighet}

Begrepet verdighet er et normativt begrep. Det sier noe om hvordan man skal handle og hva slags handlinger man skal avholde seg fra å gjøre i situasjoner der personer kan bli vesentlig berørt av våre valg og handlinger. 
Kant uttrykker dette med den såkalte menneskelighetsformuleringen av det kategoriske imperativ: «Handle slik at du alltid bruker menneskeligheten så vel i din egen person som i enhver annens person samtidig som et formål og aldri bare som et middel.» (Kant, 1983, s. 46 [4:429]) Gitt koblingen mellom menneskelighet og verdighet følger det at kravet om hensyn til menneskelighet er et krav om hensyn til personers verdighet.

Kant fremstiller plikt knyttet til verdighet først og fremst som negativ plikt, plikt til å avstå fra bestemte handlinger. Et formål i seg selv er «et formål man aldri må handle mot» (Kant, 1983, s. 53 [4:437]). Handling i strid med verdighet er handling som går ut på å behandle personen som rent middel. Personen blir gjennom handlingen redusert til en ting eller et redskap som den handlende bruker etter eget forgodtbefinnende. Et eksempel på en slik handling ville være å be om et lån for å komme seg ut av en vanskelig økonomisk situasjon med et løfte man ikke akter å holde om å betale det tilbake (Kant, 1983, s. 40-41 [4:422]). Den som, uvitende om den andres intensjon, samtykker i å gi lånet, vet ikke hva han samtykker i, for han er blitt villedet til å tro at han vil få pengene tilbake. Han kan ikke selv i en slik situasjon handle for egne formål. Og å straffe en forbryter med henblikk på å reformere ham eller tilfredsstille samfunnets behov eller ønsker er å handle i strid med forbryterens eksistens som formål i seg selv, for «mennesket kan aldri håndteres bare som middel til en annens hensikt og forveksles med eiendom ...» (Kant, 1991, s. 140-141 [6:331]) For å være forenlig med forbryterens verdighet må straff være rettet mot forbryterens person, den som er opphav til og ansvarlig for ugjerningen som er begått.

At en person er subjekt for formål og handlinger utelukker ikke at personen, i likhet med ting, er objekt. En person er både en som gjør noe, og en som blir eller kan bli gjort noe med, både giver og mottaker. Christine Korsgaard har påpekt at én forskjell mellom kantianeren og nytteetikeren går på vektleggingen av den ene eller andre side ved personen (Korsgaard, 1996, s. 363). Mens nytteetikeren vektlegger personens evne til å bli tilfredsstilt, og er opptatt av hva som skjer med personen, vektlegger kantianeren handlingen fra den handlendes ståsted og er opptatt av hva personen gjør. En handling er i strid med verdighet og går ut på å behandle personen som rent middel fordi den er uforenlig med den 
berørte som aktør, som et moralens og handlingens subjekt. En person blir behandlet som rent middel, der han utelukkende tjener en annens formål og således ikke selv kan være subjekt for egne formål.

En aktørbasert tanke om verdighet stiller også, ifølge Kant, krav til personens handling selv om den bare berører ham selv. På grunnlag av en slik tanke avviser Kant enhver transaksjon mellom to personer der den ene samtykker i å være den andres slave (Kant, 1991, s. 139 [6:329-30]). Til personens menneskelighet hører å være sin egen herre. I kraft av sin menneskelighet har enhver person en medfødt rettighet: frihet i betydningen «uavhengighet av en annens tvingende vilje» (Kant, 1991, s. 63 [6:237]). Frihet i denne betydning er fraværet av en annens herredømme, ikke bare fravær av en annens tvang eller hindring (jf. Skinner, 2002, s. 255 ff.). Selv om den som underordner seg en annen som dennes slave, er fritt samtykkende - han kan tenkes å ha som mål å sikre egen trygghet og tilfredsstillelse av sine behov - er ikke transaksjonen frihetsbevarende i relevant forstand. En slave har status som en annens ting eller redskap, en som til enhver tid må være beredt til utelukkende å tjene en annens formål, og som ikke selv kan være subjekt for et hvilket som helst formål.

Selvmord er også, ifølge Kant, handling i strid med verdighet i egen person. Hans eksempel er den som av livslede, uten utsikt til forbedring, velger å ta sitt liv. Nytteetikeren kan kanskje forsvare en slik handling som middel til å unnslippe smerte. Fra et kantiansk ståsted innebærer dette, og den handlendes motivasjon, en vektlegging av personen som objekt. Menneskeligheten, subjektet for et utall formål, blir «ofret», utslettet, for behagets skyld. Kant karakteriserer selvmord som «utslettelse av moral i egen person» (Kant, 1991, s. 219 [6:423]). Selvmord er en forbrytelse overfor en selv, til tross for at man er samtykkende til handlingen. Riktignok vurderer Kant selvmord under forutsetningen av at man som fornuftig vesen er sin egen herre og har kontroll over seg selv. Begrensningen i en slik vurdering er at den ikke tar høyde for omstendigheter som kan drive en person til å ta sitt eget liv. Den som gjør dette i dyp og kanskje uhelbredelig depresjon, er ikke i like stor grad sin handlings frie årsak.

På den annen side problematiserer Kant noen omstendigheter rundt det å ende eget liv. Er det selvmord å ofre sitt liv for sitt eget land (Kant, 1991, s. 219 [4:423])? Ett eksempel på det såkalte heroiske selvmord er da 
den amerikanske soldaten i Irak, Ross McGinnis, la seg på en granat som hadde landet inne i stridsvognen han bemannet, for å skjerme og redde livet til fire medsoldater som befant seg inne i stridsvognen uten mulighet til å redde seg ut (Kerstein, 2009, s. 526 f.). Og Kant spør om det er galt av personen med rabies, vitende om sykdommens dødelige utfall, å ende sitt liv for å unngå å skade andre (Kant, 1991, s. 220 [6:423-24]). Felles for disse tilfellene er at de involverer andre personer i tillegg til den handlende selv. De er villede handlinger som ikke utelukkende er motivert av den handlendes hensyn til seg selv i egoistisk forstand. Her er det ikke åpenbart at personens menneskelighet blir underkastet et rent subjektivt, vilkårlig formål. Er det moralsk forskjell for Kant mellom det egoistiske og det heroiske selvmord? Eller er det å ende sitt liv uansett i strid med verdighet? Kant signaliserer at man av hensyn til verdighet $i$ egen person bør være beredt til å ofre sitt liv. Selv der man trues med døden for ikke å rette seg etter en fyrstes pålegg om å rette falske anklager om en uskyldig person, skal man følge plikten til ikke å lyve (Kant, 2007, s. 192 [5:155-56]).

Det fremgår av Kants drøftinger at tanken om verdighet er begrensende også for handling som angår en selv. Verdighet innebærer ingen rett til å disponere over egen person etter eget forgodtbefinnende. Kant skjelner mellom det å være sin egen herre - sui iuris - og det å være eier av seg selv - sui dominus (Kant, 1991, s. 90 [6:270]). En person er ikke sin egen besittelse eller eiendom (sui dominus) som han kan bruke eller disponere over etter eget forgodtbefinnende, slik man kan med en ting.

\section{Verdighet og grunnleggende rettigheter}

En aktørbasert tanke om verdighet er i vår tid blitt formulert av den amerikanske filosofen Alan Gewirth. I likhet med Kant forstår han verdighet som en iboende, ukrenkelig verdi ved personer. Gewirth tar utgangspunkt i menneskelig handling. Slik handling har to grunnleggende karakteristikker. Den er fri eller frivillig, og den er målrettet i betydningen at den som foretar en handling, har et formål eller en hensikt som man søker å nå eller realisere gjennom handlingen, det Kant har kalt «subjektivt formål». Den handlende tillegger formålet for sin handling en verdi som er tilstrekkelig for å motivere til handlingen. Gewirth tenker seg at den 
handlende som tillegger formålet verdi må, som verdiens eller verdsettelsens opphav, betrakte seg selv som innehaver av ufravikelig verdi, dvs. verdighet (Gewirth, 1982, s. 28-29; Gewirth, 1992, s. 22). Den handlende må også anerkjenne enhver annen aktørs verdighet, på samme grunnlag som han betrakter seg selv som innehaver av verdighet. For enhver menneskelig aktør kan ikke, uten å motsi seg selv, benekte at andre mennesker kan være aktører, i besittelse av verdighet, og samtidig forvente at andre tar hensyn til ham som aktør og dermed innehaver av verdighet (Gewirth, 1992, s. 23). Med andre ord: Begrepet om menneskelig handling impliserer tanken om aktørers iboende verdighet.

Gewirth slutter seg til tanken om at menneskets verdighet ligger til grunn for menneskerettigheter: «Det er fordi mennesker har verdighet, at de har menneskerettigheter.» (Gewirth, 1992, s. 10; f.eks. Schaber, 2014, s. 159 ff.) Den som av hensyn til egen vinning handler i strid med en persons menneskerettigheter, handler på en måte som ikke anerkjenner dennes verdighet. Menneskerettigheter gjelder uavhengig av positiv lovgivning. De er «generiske rettigheter». Sentralt for tanken om slike rettigheter hos Gewirth er det han kaller «prinsippet om generisk konsistens» - "the principle of generic consistency», PGC: "[du skal] handle i samsvar med de generiske rettigheter til dem som berøres av din handling og med dine egne generiske rettigheter.» (Gewirth, 1982, s. 52) ${ }^{2}$ Også for slike rettigheter har Gewirth et argument basert på menneskelige handlingers egenskaper av å være frivillige og målrettede. Generiske rettigheter er krav om de nødvendige betingelser for menneskelig handling: den handlendes frihet og velbefinnende - «well-being» (Gewirth, 1982, s. 47 ff.). Ethvert menneske må som handlende i relevant betydning hevde sin rett til egen frihet og eget velbefinnende og kreve av andre at de respekterer disse rettighetene. Samtidig må enhver aktør anerkjenne at andre menneskelige handlende i relevant forstand har tilsvarende rettigheter som man selv plikter å ta hensyn til i valg og handling. Alle aktører har de samme generiske rettigheter, rett til frihet og velbefinnende (Gewirth, 1982, s. 51-52). Disse er grunnleggende rettigheter knyttet til menneskelig handling overhodet. Gewirth forstår frihet først og fremst i 
negativ betydning som fravær av andres tvang eller inngrep (1982, s. 53; jf. Berlin, 1969, s. 122 [no. overs. s. 297-298]). Den positive siden ved frihet i denne betydning er evnen til å handle i henhold til eget valg eller ønske (Gewirth, 1982, s. 311). Retten til velbefinnende innebærer retten til realisering av betingelsene for å lykkes gjennom handling, rett til liv, til ikke å bli bedratt eller svindlet, til å forbedre egen situasjon, blant annet retten til utdannelse (1982, s. 139).

\section{Noen etiske problemstillinger}

I vår tid er tanken om verdighet blitt anvendt på mer konkrete problemstillinger. Noen aktuelle problemstillinger er: å holde i live eller la dø, aktiv dødshjelp, å kaste kortvokste mennesker for sport og underholdning («dwarf-tossing»). Siden tanken om verdighet i dette kapitlet knyttes til evnen til selvbestemmelse med utgangspunkt i Kants tanke om verdighet, er det på sin plass å ta visse forbehold i drøftingen av disse problemstillingene. Det er ikke tale om direkte eller bokstavelig anvendelse av Kants moralfilosofi eller moralfilosofiske prinsipper. Sentral for drøftingen av problemstillingene er vektleggingen av en aktørbasert tanke om verdighet. Dette kan gi andre konklusjoner enn dem som måtte følge av Kants moralfilosofi.

\section{Holde i live eller la dø?}

For etiske problemstillinger har man tradisjonelt skjelnet mellom to klassiske tilnærmelser. Den ene, pliktetikk, som gjerne assosieres med Kant, legger vekt på prinsipp og plikt. Ifølge en slik etikk er en handlings verdi eller moralske status en egenskap ved handlingen selv, uavhengig av handlingens konsekvenser eller de hensikter man måtte ha med handlingen. Det er bestemte handlinger man skal gjøre fordi de er plikter, og det er bestemte valg og handlinger man skal unngå. Den andre tilnærmelsen, nytteetikk (utilitarisme), legger vekt på handlingers konsekvenser, ikke deres iboende karakter. Man bør velge handlinger som har de mest fordelaktige konsekvenser for flest mulig (f.eks. Mill, 1979, s. 7 f.). 
Men det kan være konkrete problemstillinger der hensynet til verdighet knyttet til personers selvbestemmelse tilsier at begge disse tilnærmelsene er utilstrekkelige. Her er et eksempel på en slik problemstilling innen medisin og helse (Waymack, 1996, s. 1). En betydelig dement kvinne i 90-årene, uten pårørende eller venner, er overført fra sykehjem til sykehus med kraftig lungebetennelse. Uten respiratorbehandling vil hun sannsynligvis ikke overleve. Skal denne gamle, nesten døende kvinnen gis slik behandling? Pliktetikeren ville antakelig argumentere for at det er plikt å opprettholde en persons liv, å motvirke personens død med alle tilgjengelige midler. Dette er et standpunkt man også ville innta med den tidligere nevnte tanken om verdighet knyttet til det å være menneske som sådant. Nytteetikeren, på sin side, ville vurdere allmenn nytte, fordeler og ulemper ved hvert tilgjengelige handlingsalternativ. Problemet med slike etiske utlegninger er at den bestemte personen det her dreier seg om, blir totalt oversett. Hun blir rent objekt for etiske utlegninger.

En tredje tilnærmelse ville bruke elementer fra narrativ etikk (Waymack, 1996, s. 3-4). Narrativ etikk vektlegger den berørtes historie, personens fortelling («narrative»), for løsning av etiske problemstillinger. Er det opplysninger om og ved denne personen som kan bidra til at man finner en løsning på problemstillingen? Har hun gitt uttrykk for at hun i så høy alder er mett av dage, eller har hun vist ønske om eller vilje til å leve videre? Personens fortelling kan være rettesnor for, eller veiviser til, etisk riktig handling overfor denne personen, eller i alle fall det beste handlingsalternativet ut fra det man vet. Til vår tids tanke om verdighet hører gjerne kravet om å innhente den berørtes samtykke (f.eks. Parsons \& Hooker, 2010, s. 346). Med grunnlag i fortellingen kan det handlingsalternativet velges som man tror den berørte personen mest sannsynlig selv ville ha valgt eller gitt sitt samtykke til. Men for denne type overveielse og handlingsvalg er det ingen fasitsvar. Mens fortellingen til én person som har signalisert at hun er mett av dage, tilsier at hun ikke kobles til respirator, tilsier historien til den som har vist vilje til å leve, at hun blir koblet til respirator. Hensynet til personens fortelling anerkjenner den berørte selv som subjekt for valg og handling, også der personen ikke selv er i stand til å meddele ønske eller vilje. Denne tilnærmelsen fremstår som forenlig med tanken om at verdighet er knyttet til personen som aktør, som valgets og handlingens subjekt. 


\section{Aktiv dødshjelp?}

En sentral problemstilling i lys av tanken om menneskeverdet har å gjøre med aktiv dødshjelp. Aktiv dødshjelp er basert på en persons ønske om å dø og innebærer assistanse fra en annen person, som regel en lege, til å bevirke personens død. Den som ønsker å dø, lider av dødelig sykdom og er i en livstilstand preget av fysisk smerte og gjerne også nedsatt funksjonsevne. Personen ønsker en slutt på livet for å unnslippe lidelse man ikke ellers kommer ut av. Aktiv dødshjelp kan ha form av eutanasi («barmhjertighetsdrap») eller assistert selvmord. Ved eutanasi blir personens død bevirket av en annen, en lege som setter en dødelig sprøyte. Ved assistert selvmord skaffer legen middelet som personen så bruker for å forårsake sin egen død. Aktiv dødshjelp er forbudt i de fleste land, men det er unntak. Eutanasi er tillatt i noen europeiske land, blant annet Holland (Brock, 1992, s. 10). Assistert selvmord er tillatt i noen amerikanske delstater, blant annet Oregon (Robinson \& Scott, 2012, s. 41). Fra et rettslig ståsted er problemet med aktiv dødshjelp at den innebærer en persons medvirkning til en annens død, og dermed har likhetstrekk med drap. På den annen side gjør det at vi i dag har teknologi som kan holde folk i live, og dermed forlenge den enkeltes liv i strid med dennes ønske, aktiv dødshjelp til en aktuell etisk problemstilling, til tross for eksisterende lovforbud. Vår tids livsforlengende teknologi kan representere en svekkelse av den enkeltes kapasitet til å bestemme over eget liv.

I etisk argumentasjon til støtte for aktiv dødshjelp heter det at den enkelte skal kunne velge «å $\mathrm{d} ø$ med verdighet» - «die with dignity» (f.eks. Battin, 1994, s. 287n.15). Med dette uttrykket forstår man gjerne det å unnslippe en livstilstand som står i motsetning til en tidligere livstilstand eller en livstilstand ethvert menneske med rimelighet bør kunne realisere for seg selv. Her fremstår verdighet som noe, en type tilstand, man ikke nødvendigvis er i besittelse av, men $b ø r$ ha. Men vi kan kanskje omtolke uttrykket og si at «å dø med verdighet» er å dø på en måte som er i overensstemmelse med verdighet. Også døden er tenkt som gjenstand for den enkeltes selvstendige valg. Grensene for hva man kan velge for seg selv, bør ikke være mer omfattende for den uhelbredelig sykes eller hjelpeløses valg og handling enn for enhver annen som er subjekt for et utall formål. Med utgangspunkt i en aktørbasert forestilling om verdighet er da 
spørsmålet om aktiv dødshjelp bør være tillatt når det foreligger et ønske om å dø hos en som ikke lenger har utsikt til å være subjekt for et utall formål. Er det slik at den enkeltes kontroll og myndighet over eget liv, retten til å velge for seg selv, også omfatter retten til å dø, enten ved egen hjelp eller ved kompetent assistanse til dette?

Likhetstrekk med en persons drap av en annen er bare én side ved aktiv dødshjelp. Aktiv dødshjelp har også likhetstrekk med selvmord, siden utgangspunktet er den berørtes egen vilje. Fra et slikt perspektiv blir en annens medvirkning et moment som har mindre betydning. En drøfting av selvmord kan være relevant for vurdering av aktiv dødshjelp.

Kan man, med grunnlag i tanken om verdighet, nyansere mellom berettiget og uberettiget selvmord? Ifølge fremstillingen av Kants standpunkt, ville hans svar være benektende for alle tilfeller av selvmord der handlingens formål er et subjektivt, vilkårlig formål. Likevel kan man spørre om det ikke er en betydelig moralsk forskjell mellom følgende to tilfeller av selvmord eller selvmordsforsøk (Battin, 1994, s. 277-278, 281-282). Det ene tilfellet er den gamle, som var nesten blind av grønn stær og dødssyk av kreft, som ble behandlet med kjemoterapi som bare var midlertidig livsforlengende, og som levde et liv i smerte, dempet av daglig forsyning av hydromorfon, et morfinlignende smertestillende middel. Denne gamle la til side hydromorfonen hver dag i en uke, og utsatte seg for stor smerte, for så å kunne ta en dødelig dose og dermed ende sitt liv. (Det hører til historien at den gamle ble oppdaget før hun døde og ble holdt i live, åpenbart mot sin vilje.) Det andre tilfellet er den 15-år gamle gutten som hoppet i døden fra en bro fordi hans favoritt-TV-serie, «Battlestar Galactica», var blitt stoppet. Den gamle har søkt å «dø med verdighet», mens det er vanskelig å si det samme for den unge gutten. Mens vi er beredt til å mene at den gamle har god grunn til å ende sitt liv, gjelder ikke dette 15-åringen. Det synes ikke som om hans rett til å bestemme over seg selv omfatter retten til å ende sitt eget liv under de omstendighetene.

Relevant for disse vurderingene er spørsmålet om hva slags liv, hvis det var tilgjengelig, man ville velge for seg selv (Battin, 1994, s. 281). Den gamle ville antakelig velge et sunt og aktivt liv, et liv som subjekt for et utall formål, som ikke var tilgjengelig for henne. Den unge valgte bort et 
sunt og aktivt liv som subjekt for et utall formål, et liv som var tilgjengelig. Omstendighetene omkring deres respektive valg gjør dem forskjellige. Den gamles valg fremstår som forståelig og rasjonelt. Den unges valg har karakter av å være meningsløst og irrasjonelt. Hvis det er en moralsk forskjell mellom disse tilfellene, kan det være fordi den gamle, men ikke den unge, finner støtte til å ende sitt eget liv i en aktørbasert forestilling om verdighet. Tilsvarende betraktninger gjelder for aktiv dødshjelp i den grad det er vesentlige likhetstrekk med den gamles valg.

Ifølge Gewirth står det i prinsippet den enkelte fritt til å skade seg selv eller ende sitt liv når andre enn den handlende selv ikke berøres i betydelig grad (Gewirth, 1978, s. 264 ff., 324). Fra aktørens ståsted er de nødvendige betingelser for frivillig og målrettet handling oppfylt. Det ville være i strid med den handlendes verdighet som aktør for andre å gripe inn i og forsøke å forhindre selvskading eller selvmord. Likevel kan man kanskje vurdere de to tilfellene forskjellig, i lys av Gerwiths PGC. Til frivillig og målrettet handling hører refleksjon og overveielse (Gewirth, 1978, s. 42; Gewirth, 1982, s. 29). Menneskelig handling er ikke nødvendiggjort av ytre omstendigheter, men har sitt opphav i den handlende selv, som etter nærmere refleksjon eller overveielse kan endre sitt handlingsvalg. Menneskets grunnleggende, «generiske» rettigheter innebærer frihet til selv å endre sitt valg og å endre oppfatninger om eget velbefinnende, i henhold til egen refleksjon og overveielse. Det er lett å forestille seg at den gamles handling var frivillig og målrettet, at den var resultat av refleksjon og overveielse, i samsvar med hennes oppfatning om eget velbefinnende. Den gamle handlet i tråd med sine grunnleggende rettigheter. Å stoppe henne i denne handlingen, slik man faktisk gjorde, er i strid med hennes iboende verdighet som aktør. Den unge gutten, derimot, kan tenkes å ha handlet uten den grad av refleksjon og overveielse som må forutsettes for frivillig og målrettet handling, i strid med sine grunnleggende rettigheter og således i strid med PGC. I så fall ville det ikke være i strid med verdighet for hans vedkommende om andre skulle hindre ham i å handle som han gjorde. Relevant for en slik vurdering kan være guttens alder. Mens handlingen utført av en 15 år gammel gutt er i strid med PGC, kan tilsvarende handling, av samme grunn, utført av en voksen tenkes å være frivillig og målrettet i relevant forstand og således i samsvar med dennes verdighet som aktør. 


\section{Å kaste kortvokste personer for sport og underholdning?}

Denne problemstillingen skriver seg fra en sak i Frankrike i 1995, der ordføreren i byen Morsang-sur-Orge nedla forbud mot en konkurranse i kasting av kortvokste personer («dwarf-tossing») som skulle finne sted på et av byens utesteder (Rosen, 2012, s. 63 ff.). Begrunnelsen var at slik aktivitet forstyrrer offentlig ro og orden fordi den er i strid med verdighet hos den som er kasteball (i fysisk forstand). Forbudet ble bekreftet av Frankrikes Conseil d'État (høyesterett). Den kortvokste personen involvert i denne saken, Manuel Wackenheim, påklaget avgjørelsen, først til Den europeiske menneskerettighetsdomstol, så til FNs komité for menneskerettigheter, som også støttet det opprinnelige forbudet. Wackenheim argumenterte at det var diskriminerende og i strid med hans verdighet å forhindre ham i å tjene til livets opphold slik han selv fant best.

I en lignende sak i Florida uttalte den berørte personen, David Flood, kjent som "Dave the Dwarf»: «Dette er alvorlig, for jeg vil ikke at staten skal fortelle meg hva jeg kan eller ikke kan gjøre. De går ut fra [at kortvokste mennesker] ikke har egen fornuft. Folk forveksler utbytting og utnyttelse [for egen fordel]. Hvis jeg var sju fot høy, ville jeg ha blitt betalt for å slippe en basketball gjennom en kurv.» (Leget et al., 2009, s. 227) Den berørtes standpunkt for å tillate kasting av kortvokste personer kan begrunnes ut fra tanken om verdighet knyttet til den enkeltes selvbestemmelse: «Betyr ikke det å bli behandlet med verdighet at vi skulle ha rett til å gjøre egne valg om å oppføre oss med verdighet eller ikke?» (Rosen, 2012, s. 69) Mot dette har foreningen for kortvokste personer i USA støttet et forbud, fordi den mener at den type aktivitet som forbys «bryter ned den status og aktelse som kortvokste personer («little people») forsøker å oppnå for seg selv» (Rosen, 2012, s. 69).

Hvis kasting av kortvokste personer er nedverdigende for den berørte, som på sin side er samtykkende, er det normalt ingen som i betydelig forstand lider urett eller skade av slik aktivitet (jf. Rosen, 2012, s. 69). Her kan man skjelne mellom ulike prinsipielle standpunkt som med grunnlag i en forestilling om verdighet kan tenkes å komme til motstridende konklusjoner. Det ene kan assosieres med Kant og hans tanke at den enkeltes verdighet innebærer grenser for hva man gjør med seg selv, alene eller i 
omgang med andre. Kant har i en forelesning over moralfilosofi erklært: «... den som for egen vinning lar seg bruke til alt mulig av en annen, som en ball, forkaster menneskets verdighet.» (Kant, 1997, s. 123 [27:341]) Ved å innlate seg på kasting av kortvokste mennesker gjør den kortvokste seg selv til et rent redskap, en ting, for andres underholdning. Det at han er samtykkende og får betalt, og at ingen er skadelidende eller forurettet, har mindre betydning. En slik vurdering ligner den Kant gjør for prostitusjon (Kant, 1991, s. 97 [6:278-279]). Den som av egen vilje selger seksuelle tjenester, en handel om kjøpers seksuelle nytelse og selgers økonomiske eller materielle gevinst, gjør seg likevel til en annens redskap. Problemet for Kant er at de delaktige i et slikt forhold ikke fremstår som likeverdige. Å stille en vesentlig side ved sin person, kroppen, til disposisjon for den annens nytelse eller underholdning, er å underordne seg en annen på en måte som ikke er gjensidig. Selv om Kant knytter verdighet til personen som subjekt for et utall formål, legitimerer ikke dette et hvilket som helst valg subjektet måtte ta.

Et annet, liberalistisk standpunkt kan knyttes til John Stuart Mill (1806-1873). Ifølge ham er enhver person absolutt herre («sovereign») over seg selv, over eget legeme og sinn (Mill, 1989, s. 13 [no. overs. s. 18]). Den enkelte har rett til å handle overfor seg selv etter eget forgodtbefinnende, såfremt andre ikke berøres negativt av handlingen. For Mill, i motsetning til Kant, er personen sin egen eiendom. Ifølge Mill er det ikke noe ved ens egen person som setter absolutte moralske grenser for hvordan man forholder seg til seg selv. Med unntak av å underordne seg en annen som dennes slave (jf. Mill, 1989, s. 102-103 [no. overs. s. 120-121]), står det den enkelte fritt å bruke seg selv eller stille seg selv til andres disposisjon når andre ikke forurettes, skades eller på annen måte forulempes i betydelig $\operatorname{grad}$ (Mill, 1989, s. 13 [no. overs. s. 18]). Liberalisten har ingen problemer med å mene at det ikke er i strid med verdighet knyttet til selvbestemmelse at den kortvokste selv skal kunne velge å bruke sin egen person og fysiske egenskaper til andres underholdning. Gewirth inntar et tilsvarende standpunkt. Det avgjørende for ham er at handlingen er frivillig og målrettet i relevant forstand. Slik tilfellene over er fremstilt, er både Manuel Wackenheim og David Flood selvstendige og frivillige handlende som søker å fremme eget velbefinnende. Et forbud mot «dvergkasting» 
er et inngrep i strid med deres frihet i negativ forstand og dermed i strid med iboende menneskeverd.

Den vesentlige forskjellen mellom dette standpunktet og Kants har å gjøre med verdighetens forankring. For Kant er det tale om en ufravikelig verdi i personen som fornuftsvesen. Verdighet innebærer et krav om at den enkelte ikke velger og handler i strid med seg selv som fornuftsvesen. For et liberalistisk standpunkt, og for Gewirth, ligger denne verdien snarere i det å være fritt velgende (og målrettet) aktør, uavhengig av hva man faktisk velger for seg selv, så lenge andre ikke skades eller forurettes.

\section{Utfordringer mot tanken om verdighet - kritiske problemstillinger \\ Forestillingen om verdighet er meningsløs og intetsigende}

Denne siste problemstillingen viser at ulike forestillinger om eller forankringer av verdighet kan gi motstridende konklusjoner. Dette poenget kan også gjøres gjeldende for de to foregående problemstillingene. Hvis forestillingen om verdighet knyttet til det å være menneske eller skapt i Guds bilde innebærer tanken om at menneskelivet er hellig, så følger det for den gamle med lungebetennelse at man skal forsøke å holde henne i live under enhver omstendighet. Hva hun selv kan ha gitt uttrykk for, vilje til å leve eller til å dø, har ingen betydning. Ut fra samme forestilling er aktiv dødshjelp i strid med verdighet selv om den berørte selv ønsker å dø. Hensynet til den enkeltes vilje og livssituasjon må vike for hensynet til verdighet knyttet til det å være menneske. Denne forestillingen om verdighet utelukker en moralsk nyansering av det å ende sitt eget liv.

Slike observasjoner har gitt opphav til innvendinger mot begrepet verdighet som et operativt normativt begrep (f.eks. Dupré, 2012, s. 264). At forestillinger om verdighet inngår i motstridende argumenter og konklusjoner har foranlediget tanken om at verdighetsbegrepet selv er uklart og mangler presis mening. Ifølge Ruth Macklin er verdighet et «ubrukelig begrep» og kan mer presist forstås som «respekt for personer eller deres autonomi» (Macklin, 2003, s. 1419-1420). En beslektet innvending 
går ut på at «begrepet verdighet er som sådant intetsigende». Det er en forestilling man tyr til i argumentasjon «når man har sluppet opp for rasjonelle begrunnelser» (Bagaric og Allen, 2006, s. 260). For det første finnes mange ulike karakteristikker og derfor ingen entydig definisjon av iboende verdighet (Bagaric og Allen, 2006, s. 264-265). For det andre gir bruken av begrepet motstridende konklusjoner om problemstillinger som for eksempel aktiv dødshjelp (Bagaric og Allen, 2006, s. 266-267).

Forslaget om å erstatte begrepet verdighet med «respekt for personer eller deres autonomi» er et forslag om å erstatte tanken om en verdi som personen selv er innehaver av, noe objektivt, med forestillingen om en holdning, noe subjektivt, overfor personen eller dennes evner. Men å gi avkall på tanken om iboende verdighet kan være å forlate tanken om noe ved personen som har moralske implikasjoner for valg og handling som er rettet mot eller berører personen på en vesentlig måte. Iboende verdighet er et moralsk vern i personen selv mot å bli utnyttet av andre og å bli vurdert utelukkende ut fra den nytte man er for andre mennesker og for stat eller samfunn (f.eks. Andorno, 2009, s. 230-231). At forestillinger om verdighet kan brukes til motstridende konklusjoner kan heller foranledige bestrebelser på å formulere og enes om tydeligere kriterier for verdighet.

\section{Tanken om verdighet er selektiv og ekskluderende}

Det er blitt påpekt at Kants tanke om verdighet egentlig ikke er en tanke om menneskeverdet (von der Pfordten, 2009, s. 379). For Kant har verdighet å gjøre med fornuftsvesenet og dets evne tilå styre seg selv i henhold til egen fornufts lover. Verdighet tilhører det Kant kaller «homo noumenon», personen tenkt som delaktig i en rent fornuftsbestemt orden, til forskjell fra tilværelse som «homo phaenomenon» i en verden av sanselige impulser, behov og ønsker. Denne begrensningen viser til en innvending rettet mot tanken om verdighet knyttet til autonomi og evne til selvbestemmelse i valg og handling. Verdighet gjelder ifølge en slik tanke bare dem som faktisk har evne til rasjonell overveielse i valg og handling, til utelukkelse av barn, demente, og andre som ikke har eller fullt ut kan utvikle relevante evner og ferdigheter (f.eks. Düwell, 2014, s. 33; Schroeder, 2012, 
s. 329-331). Så etiske hensyn på grunnlag av denne tanken om verdighet ville være begrenset til hensyn til dem som er i besittelse av evnen til rasjonell overveielse $\mathrm{i}$ valg og handling. Den alternative tanken om verdighet, knyttet til det å være menneske, styrer klar av en slik innvending (f.eks. Schaber, 2014, s. 156-157).

Også for dette punktet har Gewirth relevante betraktninger. Aktører kan graderes som mer eller mindre i stand til å utføre frivillig og målrettet menneskelig handling (Gewirth, 1978, s. 120-125, 140-142). Noen har bedre utviklet evne til refleksjon og overveielse enn andre. De kan reflektere over og velge flere mulige mål for seg selv og således være opphav til et større omfang av frivillig og målrettet handling. Menneskers grunnleggende, «generiske» rettigheter har å gjøre med de nødvendige betingelser for slik handling. Omfanget av en aktørs generiske rettigheter er betinget av i hvilken grad aktøren evner å utføre slik handling. Av to mennesker, hvorav den ene, A, er i full grad i stand til å utføre menneskelig handling, og den andre, B (barn eller mentalt funksjonshemmet), mangler noen evner til dette, har A et større omfang av generiske rettigheter enn B. Med andre ord, et barn eller en mentalt funksjonshemmet har ikke de samme eller like omfattende rettigheter som en voksen person som ikke er funksjonshemmet. Av hensyn til én type rettighet, retten til velbefinnende, må barns og funksjonshemmedes frihet som regel begrenses av andre (Gewirth, 1978, s. 142). På den annen side er barn og andre som ikke har fullt ut utviklede evner til å utføre menneskelig handling, også aktører i den betydning at de har mål for sine handlinger som de tillegger verdi, og i dette henseende selv er opphav til verdier. Dette er, ifølge Gewirth, tilstrekkelig for å være i besittelse av verdighet (jf. 1982, s. 29). At mindre utviklet aktør B har færre eller mindre omfattende generiske rettigheter enn mer utviklet aktør A, innebærer ikke annet enn at inngrep i Bs tilværelse eller atferd kan være forenlig med Bs verdighet, mens tilsvarende inngrep ville være i strid med As verdighet.

\section{Avsluttende bemerkninger}

For tanken om verdighet og dens etiske eller moralske implikasjoner er det en tendens til å legge vekt på hvordan personer berøres eller påvirkes 
i betydningen av å være gjenstand for andres handling. Den handling er i strid med verdighet som skader eller foruretter en annen og er uforenlig med dennes eksistens som menneske. Her fremstår den andre som moralsk objekt, en som blir gjort eller ikke gjort noe med. En grunn som kan forklare en slik orientering er aktualiseringen av tanken om verdighet i lys av holocaust under den 2. verdenskrig (f.eks. Barak, 2015, s. 34). For jøder å bli stuet inn i kuvogner, å bli offer for nedskytninger, å bli sendt i gasskammer og så brent er åpenbart i strid med iboende verdighet. Ofrene ble gjort noe med, behandlet som ting og ikke anerkjent som mennesker. Men for en aktørbasert forestilling om menneskets verdighet er det å behandle en person som ting i strid med verdighet også fordi slik handling er uforenlig med å behandle og anerkjenne mennesket som moralens og handlingers subjekt. Naziregimets systematiske mishandling og utryddelse var uforenlig med ofrenes eksistens som subjekt for alle mulige formål. For den aktørbaserte tanken om verdighet er det ikke tilstrekkelig å sikre mennesket mot å lide nød eller bli forurettet eller skadet. Tanken om verdighet innebærer et krav om en livstilstand der enhver kan være subjekt for menneskelig handling og for et utall formål.

På dette punktet aner man likevel en forskjell mellom Gewirths posisjon og Kants. For Gewirth innebærer tanken om menneskets verdighet et krav om bevaring av eller respekt for den enkeltes frihet $\mathrm{i}$ betydningen fravær av andres inngrep eller tvang. Sentral for hans aktørbaserte forståelse av verdighet er det han mener er den positive side ved begrepet negativ frihet: den enkeltes selvbestemmelse i valg og handling etter eget forgodtbefinnende. Frihet for Kant, derimot, er fravær av en annens herredømme. I politisk sammenheng er den fri som «ikke er underlagt annen lov enn den han har gitt sitt samtykke til», ifølge ham (Kant, 1991, s. 125 [6:314]). Hvis man generaliserer denne tanken, kan man forstå Kant dit hen at for organisert samkvem eller tilværelse med andre er frihet medbestemmelse. Slik frihet, i realiteten uavhengighet av en annens herredømme, tilkommer enhver som en «menneskelighetens rettighet i den enkeltes person» (Kant, 1991, s. 63 [6:237]). I den grad menneskelighet er ensbetydende med verdighet for Kant, impliserer tanken om verdighet for ham et krav om den enkeltes medbestemmelse i saker som berører eller angår en selv. 


\section{Forfatterbiografi}

Sven Arntzen er professor i praktisk filosofi, Universitetet i Sørøst-Norge, studiested Bø. PhD ved The Johns Hopkins University, USA, med avhandling om Kants rettsfilosofi. Har publikasjoner om Kants rettsfilosofi og moralfilosofi, miljøfilosofi og -etikk, og idehistorisk fagteori. Har undervist i filosofi på alle nivåer.

\section{Referanser}

Andorno, R. (2009). Human Dignity and Human Rights as a Common Ground for a Global Bioethics. Journal of Medicine and Philosophy, 34, 223-240.

Bagaric, M. \& Allan, J. (2006). The Vacuous Concept of Dignity. Journal of Human Rights, 5(2), 257-70.

Barak, A. (2013). Human Dignity: The Constitutional Value and the Constitutional Right. I Chr. McCrudden (Red.), Understanding Human Dignity (s. 359-380). Oxford: Oxford University Press.

Barak, A. (2015). Human Dignity. The Constitutional Value and the Constitutional Right. Cambridge: Cambridge University Press.

Battin, M. P. (1994). Suicide: A Fundamental Human Right? I M. P. Battin, The Least Worst Death. Essays in Bioethics on the End of Life (s. 277-288). Oxford: Oxford University Press.

Berlin, I. (1969). Two Concepts of Liberty. I I. Berlin, Four Essays on Liberty. Oxford: Oxford University Press. No. overs. (2009) v. L. Holm-Hansen, «To begreper om frihet». I: L. Svendsen (Red.), Liberalisme - politisk frihet fra John Locke til Amartya Sen (s. 295-343). Oslo: Universitetsforlaget.

Bibelen - Første Mosebok (1968). Oslo: Det norske bibelselskaps forlag.

Brock, D. W. (1992). Voluntary Active Euthanasia. The Hastings Center Report, 22(2), $10-22$.

Dupré, Catherine (2012). Dignity, Democracy, Civilisation. Liverpool Law Review, 33, 263-280.

Düwell, M. (2014). Concepts, Discussions, Philosophical Perspectives. I M. Düwell, J. Braarvig, R. Brownsword, D. Mieth, (Red.), The Cambridge Handbook of Human Dignity. Interdisciplinary Perspectives (s. 23-49). Cambridge: Cambridge University Press.

Furman v. Georgia - United States Supreme Court, 1972. I J. Feinberg og H. Gross (Red.), Philosophy of Law (5. utg., s. 723-32). Belmont, CA: Wadsworth Publishing Company.

Gewirth, A. (1978). Reason and Morality. Chicago: The University of Chicago Press. 
Gewirth, A. (1982). Human Rights. Essays on Justification and Applications. Chicago: The University of Chicago Press.

Gewirth, A. (1992). Human Dignity as the Basis of Rights. I M. J. Meyer og W. A. Parent (Red.), The Constitution of Rights. Human Dignity and American Values. Ithaca, NY: Cornell University Press.

Johannes Paulus II (1995). Evangelium Vitae 9, K. http://w2.vatican.va/content/johnpaul-ii/en/encyclicals/documents/hf_jp-ii_enc_25031995_evangelium-vitae.html - oppsøkt 12.09.2017)

Kant, I. (1983). Grunnlegging til moralens metafysikk. I E. Storheim (Red.), Moral, politikk og historie. Et utvalg fra Kants praktiske filosofi. Overs. E. SchwabeHansen \& E. Storheim. Oslo: Universitetsforlaget - original tittel: Grundlegung der Metaphysik der Sitten (1785).*

Kant, I. (1991). The Metaphysics of Morals. Overs. M. Gregor. Cambridge: Cambridge University Press - original tittel: Die Metaphysik der Sitten (1797).*

Kant, I. (1997). Moral philosophy: Collin's lecture notes. Overs. P. Heath. I: P. Heath og J. B. Schneewind (Red.), Immanuel Kant. Lectures on ethics. Cambridge: Cambridge University Press - original tittel: Moralphilosophie Collins $(1784-85)$. $^{*}$

Kant, I. (2007). Kritikk av den praktiske fornuft. Overs. Ø. Skar \& B. Hansen. Oslo: Aschehoug - original tittel: Kritik der praktischen Vernunft (1789).*

Kerstein, S. (2009). Death, Dignity, and Respect. Social Theory and Practice, 35(4), 505-530.

Korsgaard, C. (1996). Creating the Kingdom of Ends. Cambridge: Cambridge University Press.

Leget, C., Borry, P., og de Vries, R. (2009). «Nobody Tosses a Dwarf!» The Relation Between the Empirical and the Normative Reexamined. Bioethics, 23(4), 226-235.

Macklin, R. (2003). Dignity is a Useless Concept. British Medical Journal, 327, 1419-1420.

Mill, J. S. (1979). Utilitarianism (1861). Red. G. Sher. Indianapolis, IN: Hackett Publishing Company.

Mill, J. S. (1989). On Liberty (1859). Cambridge: Cambridge University Press. No. overs. (2010) v. P. Foss, Om friheten. Oslo: Vidarforlaget.

Parsons, A. \& Hooker, C. (2010). Dignity and Narrative Medicine. Bioethical Inquiry, 7, 345-351.

Ranheim, Chr. (2016). Forbrytelser mot menneskeheten. Pacem 19, 77-86.

Robinson, V. \& Scott, H. (2012). Why Assisted Suicide Must Remain Illegal in the UK. Nursing Standard, 26(18), 40-48.

Rosen, M. (2012). Dignity. Its History and Meaning. Cambridge, MA: Harvard University Press.

Saugstad, J. (2001). Kant versus Levinas. Norsk filosofisk tidsskrift, 36(1-2), 120-127. 
Schaber, P. (2014). Human Rights and Human Dignity: A Reply to Doris Schroeder. Ethical Theory and Moral Practice, 17, 155-161.

Schneewind, J. B. (1992). Autonomy, Obligation and Virtue: An Overview of Kant's Moral Philosophy. I P. Guyer (Red.), The Cambridge Companion to Kant (s. 309-341). Cambridge: Cambridge University Press.

Schroeder, D. (2012). Human Rights and Human Dignity. An Appeal to Separate the Conjoined Twins. Ethical Theory and Moral Practice, 15, 323-335.

Skinner, Q. (2002). A Third Concept of Liberty. Proceedings of the British Academy, 117, 237-268.

Von der Pfordten, D. (2009). On the Dignity of Man in Kant. Philosophy, 84(329), 371-391.

Waymack, M. H. (1996). Narrative ethics in the clinical setting. Making the Rounds in Health, Faith \& Ethics 1(15), 1-4.

* Kants skrifter er samlet i Kants Werke. Akademie-Textausgabe (Berlin: Walter der Gruyter). Henvisninger i hakeparentes er til bind og sider i den såkalte akademiutgaven, f.eks. [4:424]. Med noen få unntak følger sitater eksisterende oversettelser. Kant har en del utsagn som i meningsinnhold går igjen i ulike tekster. Jeg viser bare til utvalgte forekomster av slike utsagn. 



\title{
Menneskeverdet i tre nyere tolkninger som placeholder, heuristisk og «flytende signifikant»
}

\author{
Ådne Valen-Sendstad \\ Universitetet i Sørøst-Norge
}

\begin{abstract}
In this chapter I discuss three new ways, of understanding human dignity. First, Christopher McCrudden's concern is with the fact that there is no common understanding of the concept. He argues that dignity is a placeholder. It is open to interpretations from a diversity of normative understandings, - religious and secular. Still, he argues for a core of overlapping content within the diversity of understandings. Second, Catherine Dupré understands human dignity as a heuristic concept, open for new interpretations. The concept is in itself inexhaustible. New meanings develop in confrontation with new issues. Observing that the concept has become one of the pillars in European law and democracies, and has been crucial in several junctions when dictatorships has fallen and democracies has been established after the Second World War, she finds that the concept comes to its right in particular in transitional and transformative situations. Finally, Costas Douzinas does not work with the concept human dignity but with the concept of the human, to whom human dignity is designated in the human rights. I reinterpret his theory to also cover the normative concept human dignity. It is brought into force by proclamations, and as such becomes a transformative and life changing concept in particular for people living in need of dignity.
\end{abstract}

Keywords: Human dignity, human rights, democracy, constitution, pluralism, transformation, social rights

\section{Innledning}

Begrepet menneskeverd er dynamisk. Det anvendes på et mangfold av måter og på stadig nye områder. Tradisjonelt er begrepet bundet til noe

Sitering av denne artikkelen: Valen-Sendstad, Å. (2019). Menneskeverdet i tre nyere tolkninger som placeholder, heuristisk og «flytende signifikant». I Å. Valen-Sendstad \& I. R. Christensen (Red.), Menneskeverd - en utfordring for skole og samfunn (Kap. 9, s. 215-237). Oslo: Cappelen Damm Akademisk. https://doi.org/10.23865/noasp.9o.ch9.

Lisens: CC BY-NC 4.0. 
statisk, noe som er iboende og uforanderlig ved mennesket. Jeg vil i dette kapitlet behandle tre nyere tolkninger og anvendelser av begrepet som til dels bygger på, men som samtidig utfordrer, klassiske lesninger av begrepet.

Verdenserklæringen om menneskerettigheter brakte verdighetsbegrepet inn som et fundamentalt normativt begrep. Det er i dag blitt en grunnverdi innen etikk og politikk, men historisk sett har det ikke alltid vært slik. Først etter 1948 har verdighet gradvis blitt et normativt nøkkelbegrep. Min vei inn til begrepet kommer via interesse for menneskerettigheter. Utgangspunktet for min diskusjon av verdighetsbegrepet er de engelske ordene dignity og human dignity. Jeg skiller ikke her på verdighet og menneskeverd.

I dette kapitlet tar jeg mer opp anvendelser av begrepet enn begrunnelser for det. Jeg går inn på tre relativt nye bidrag til diskusjonen av verdighetsbegrepet hentet fra en juridisk filosofisk tilnærming innenfor menneskerettighetsdiskursen. Jeg problematiserer og drøfter menneskeverdet i menneskerettighetsdiskursen med utgangspunkt i verdighetsbegrepet som «placeholder» (McCrudden, 2013b), som et heuristisk begrep (Dupré, 2015), og som «flytende signifikant» (Douzinas, 2000). Dupré og McCrudden har begge over tid skrevet om begrepets betydninger og anvendelser. Douzinas, på sin side, har riktignok ikke arbeidet med begrepet verdighet spesielt, men han gir en tolkning av menneskeforståelsen som implisitt kommer til uttrykk i menneskerettighetene. Denne tolkningen åpner etter MITT syn for en alternativ forståelse av verdighetsbegrepet.

McCrudden er opptatt av mangfoldet av tolkninger og anvendelser av verdighetsbegrepet. I likhet med flere innen menneskerettighetsdiskursen søker han mot konsensus, noe som leder han til å forstå verdighet som et placeholderbegrep, et begrep med mange tolknings- og anvendelsesmuligheter, som allikevel er bundet sammen med et overlappende innhold. McCrudden definerer dette overlappende innholdet som en minimalistisk forståelse av begrepet.

Det andre bidraget jeg ser på, er Catherine Duprés. Hun ser på innflytelsen og tolkningen av verdighetsbegrepet i europeiske konstitusjoner og domstoler på nasjonalt og europeisk nivå. Denne virkningshistorien danner så hovedgrunnlaget for hennes tolkning av begrepet. Dupré oppfatter verdighetsbegrepet som et heuristisk begrep, noe som innebærer nyskapende anvendelser. Betydningen av begrepet er ikke uttømt, det fylles med 
stadig nytt og kreativt innhold. Hun mener begrepet verdighet har blitt en av grunnpilarene i og for liberale demokratier i Europa, og fungerer for disse som en retningsviser. Douzinas, som den siste av de tre tilnærmingene jeg vil se på, drøfter ikke verdighetsbegrepet som sådan, men kobler det til forståelsen av mennesket slik det kommer til uttrykk i menneskerettighetene. Denne forståelsen beskriver Douzinas som en «flytende signifikant». Det betyr at begrepet kan fylles med et mangfold av betydninger.

Bakteppet for denne artikkelen er pedagogisk. Arbeidet med verdighetsbegrepet i en skolesammenheng er et formidlingsprosjekt av moralsk art. Det dreier seg ikke bare om en forståelse av begrepet, men også om en strategisk bruk av det i en pedagogisk sammenheng. Det anvendes som motivasjon for å anerkjenne menneskerettighetene og engasjere til moralsk ansvar. Menneskeverdet drøftes i liten grad i sammenheng med menneskerettighetsundervisning - det tas for gitt. Hvilken forståelse er det da som fyller begrepet? Mange menneskerettighets pedagoger har sitt engasjement i rettferdighet og sameksistens (Osler, 2016), andre i endring og transformering av samfunnet (Bajaj, 2012). De har til felles at MR og verdighet danner den plattformen man starter fra, og som man ikke problematiserer. Jeg tror det er viktig i undervisningssammenheng å forholde seg til den øvrige menneskerettighetsdiskursen. Nettopp dette er noe av ambisjonen med denne artikkelen. Lærere går inn i klasserom og underviser om verdighet - de formidler en idé, en moralsk verdi, med en omfattende betydnings- og virkningshistorie.

Samtidig er dette ikke et didaktisk kapittel, men et innspill til en dypere refleksjon og drøftelse. Jeg ønsker å vise noe av bredden i tolkningene av og muligheter som ligger i verdighetsbegrepet. Jeg baserer meg på antagelsen om at mangfoldet av forståelser av begrepet gir mulighet til å kommunisere med og gjøre det relevant for flere. Dette mener jeg har vært noe av suksessformelen for verdighetsbegrepets gjennomslag. Det kan invitere elever til å knytte det til sitt eget verdifundament og til selv å utforske hva det kan bety inn mot nye situasjoner.

\section{Menneskeverdighet - et placeholder-begrep}

Christopher McCrudden har drøftet teologiske, filosofiske og juridiske forståelser av menneskeverdet, samt sett på hvordan begrepet håndteres 
innen lov og rett i ulike land og regioner (McCrudden, 2008, 2014). Han mener diskursen om verdighet er mangfoldig, sprikende og motstridende, men samtidig at har den en samlende kjerne. McCrudden dokumenterer gjennom sine arbeider at verdighetsbegrepet er pluralistisk. Han skriver:

A more pluralistic, more culturally relative approach to the meaning of human dignity can be identified by looking briefly at some of the differences in the use of dignity language between the regional texts, and between the regional texts and the international texts. (McCrudden, 2008, s. 674)

Han er ikke den eneste som legger seg på en pluralistisk tilnærming til begrepet. Shultziner er en annen, og oppsummerer sitt syn slik:

The very fact that various worldviews and ideologies are strongly related to the concept of human dignity produces a paradoxical situation in that human dignity as for itself does not contain any concrete content or meaning. Because human dignity anchors different worldviews, it cannot represent any particular set of values or meaning that "naturally" stem out of it. There is no fixed and universal content that spouts out of human dignity and, hence, its content and meanings are determined separately in each legal document in accordance with the political agreement achieved at that time. (Shultziner, 2003, s. 5)

McCrudden oppfatter verdighetsbegrepet som en placeholder. Han skriver: «dignity can often function as a placeholder, accepting that there is no actual or possible agreed articulation of its content» (McCrudden, 2013a, s. 11). Placeholder er et begrep som anvendes i flere diskurser, for eksempel i matematikk, filosofi og psykoanalyse. I USA, for eksempel, er det i juridisk litteratur en etablert praksis å anvende navnet «John Doe» når man skal omtale en mistenkt i en sak hvor den mistenkte skal være anonym. Enhver mannlig mistenkt kan være John Doe. John Doe er i det tilfellet en placeholder. Som en slik placeholder kan verdighetsbegrepet fylles med et mangfold av betydninger. McCrudden mener at verdighetsbegrepet har sin styrke nettopp i at det fungerer som en placeholder, som et språklig symbol som er anvendbart innen ulike filosofiske, ideologiske og religiøse horisonter. Begrepet får forskjellig innhold ut fra forskjellige 
sammenhenger og i ulike virkelighetsoppfatninger, enten de er sekulære eller religiøse.

I likhet med Rawls (1996) kobler McCrudden variasjoner av forståelser av verdighet til mangfold av etiske grunnsyn. Hva verdighet betyr, bestemmes i lys av livstolkninger:

What emerges from these differences is that some jurisdictions use dignity as the basis for (or another way of expressing) a comprehensive viewpoint, "a whole moral world view", which seems distinctly different from region to region. (McCrudden, 2008, s. 675)

Daly formulerer det slik: «dignity is at once a universal value and a contextualized right» (Daly, 2013, s. 19). I tråd med Rawls' logikk om overlappende konsensus søker McCrudden en tynn felles forståelse av verdighet. Selv om en placeholder kan fylles med mange betydninger, mener han at det allikevel er enighet om et grunnleggende innhold. McCrudden skisserer tre elementer:

For det første innebærer tanken om menneskeverdet en ontologisk påstand: Mennesker har iboende verdighet.

For det andre innebærer menneskeverdet et moralsk ansvar: «this intrinsic worth should be recognized and respected by others» (McCrudden, 2008, s. 679). Følgen av menneskeverdet er at man må respektere at også andre har verdighet, og derfor la det prege omgangen med andre.

For det tredje har tanken om menneskeverdet betydning for forholdet mellom staten og individet (McCrudden, 2008, s. 679). Staten må respektere individers verdighet. Dette elementet er et resultat av innføringen av de moderne menneskerettighetene, som er ment å regulere forholdet mellom stat og individ.

Det er disse tre bestanddelene som utgjør minimumsskjernen i verdighet, mener McCrudden. De danner et felles grunnlag: «There is a concept of human dignity with a minimum core» (McCrudden, 2008, s. 679), men må ikke begrunnes likt: «Everyone could agree the human dignity was central, but not why or how» (McCrudden, 2008, 678). Denne minimumskjernen er heller et utgangspunkt for en dialog. Han skriver: «dignity functions as a concept around which we can meet and discuss» (McCrudden, 2013a, s. 14). Dialogen fører til utveksling 
mellom faglige diskurser og ulike tradisjoner, og kan dermed bidra til en dypere forståelse av begrepet: «Philosophical and religious traditions can contribute insights within the legal discourses (and vice versa ...)» (McCrudden, 2013a, s. 57).

Det er ikke vanskelig å finne tolkninger av verdighet som ikke deler McCruddens tre minimumselementer av begrepet. Det sentrale for McCrudden er at forståelsen av menneskeverdet som en placeholder gjør begrepet anvendelig og relevant på tvers av mange normative tradisjoner. I dette møter han motstand fra blant andre Habermas (Habermas, 2010). Habermas forankrer i stedet menneskeverdet i en rasjonell struktur som han mener er objektiv. Et mangfold av betydninger underminerer begrepet, ifølge Habermas. For McCrudden er det motsatt. Han forsvarer begrepet, og han underbygger den sentrale posisjonen menneskeverdet har i moderne pluralistiske samfunn. Menneskeverdet er en fundamentalverdi i liberale demokratier som beskytter individet mot staten. Imidlertid medfører denne forståelsen av begrepet også noen begrensninger, som gjør at viktige dimensjoner går tapt. Menneskeverdet blir et fundament for grunnleggende og viktige rettigheter, men verdighet $\mathrm{i}$ lovens forstand innebærer allikevel ikke nødvendigvis verdighet i individers liv. Menneskeverdet bidrar til å regulere forholdet mellom individ og stat, og sikrer et minimum av menneskerettigheter. Samtidig risikerer det å fungere mest på et formelt nivå. Et slikt formelt nivå gjorde det for eksempel mulig at USA fortsatte med segregeringspolitikken for fargede lenge etter at de sluttet seg til verdenserklæringen for menneskerettigheter, eller at barnefattigdommen fortsetter å øke i vårt eget samfunn i dag.

Tyngdepunktet i McCruddens posisjon ligger i hans fundamentering og legitimering av verdighet som en plattform for menneskerettigheter på tvers av forskjellige normative og juridiske tradisjoner. Det gjør at han ikke benytter seg av de muligheter som ligger i menneskeverdbegrepet. Han leverer en innover- og tilbakeskuende tilnærming. På den måten begrenser han muligheten for at begrepet kan introdusere helt nye perspektiver eller åpne for helt nye betydninger, som innrettet mot framtid og endring. Dupré, som vi nå fortsetter med, ser på begrepet i et slikt lys. 


\section{Menneskeverdet - et heuristisk begrep}

Catherine Dupré tilnærmer seg verdighetsbegrepet fra et konstitusjonelt perspektiv. Hennes interesse er den virkning, funksjon og rolle verdighetsbegrepet har hatt og har for etterkrigstidens utvikling av demokratiene i Europa (Dupré, 2013). Hennes prosjekt er imidlertid ikke et rent historisk prosjekt - det er først og fremst normativt.

Dupré beskjeftiger seg med hvordan begrepet verdighet har vært anvendt på nye måter og med nytt innhold. Hun forstår menneskeverd som et grunnleggende heuristisk begrep: «Human dignity is ... 'an intrinsically heuristic' concept» (Dupré, 2015, s. 17). "Heuristic» slik hun bruker det her, er et begrep som blant annet anvendes i forskningsteori. Man legger fram mulige tolkningsmodeller heller enn faste bevis. Disse modellene er «suggestive rather than demonstrative» (Schickore, 2018). For å komme videre i forståelsen av noe man ønsker å utforske, legger man fram kreative forslag. Hensikten er å åpne opp for, og gi ny innsikt gjennom, andre og nye perspektiver, uten nødvendigvis å ha kontroll over alle faktorene i forslaget. Det er en porsjon kreativitet med i prosessen, det er en metode for å oppnå nyskapende kunnskap.

Når Dupré forstår verdighet som et i seg selv heuristisk begrep, lener hun seg på Glenn Hughes' framstilling. Han forklarer heuristisk slik:

Something has a "heuristic" character when it invites, and serves in, the effort of discovery. The $x$ in an algebraic equation is a heuristic symbol, standing for a mathematical content which we do not yet know but aim to discover. Any word can be said to have heuristic meaning for us as soon as it piques our curiosity due to our awareness that, while we have some understanding of its meaning, our knowledge of that meaning is unclear or incomplete. Terms cease to function heuristically when we attain a satisfactorily complete understanding of themfor example, when we grasp the explanatory meaning of the word cat, or voltage. But some words denote concepts that are intrinsically heuristic in nature. These are concepts whose meaning-content can be increasingly grasped with successive acts of knowing, but where further significant discovery always remains possible, because the concept's meaning can never be fully understood by an existing human being. To say that a given word functions as an intrinsically 
heuristic concept means that it refers to an intelligible reality of which we have some understanding, but whose full or complete content remains, and will always remain to some degree, unknown to us. (Hughes, 2011, s. 8)

Menneskeverdet er etter Hughes og Duprés mening et slikt «intrinsically heuristic concept». Alle begreper er på sett og vis heuristiske - de opplyser - men de fleste får et avgrenset og oversiktlig innhold etter hvert. Det gjelder for eksempel ord som gaffel, stol, hund. At et begrep oppfattes som «i seg selv» heuristisk, innebærer at begrepet er og forblir uutgrunnelig. Det har et meningsoverskudd. Forstålsen av begrepet er i utvikling og får nye dimensjoner ettersom nye utfordringer gir nye anvendelser av begrepet. Et annet eksempel på et «intrinsically» heuristisk begrep kan være lykke, det lar seg ikke fullt ut innholdsbestemme. Bernard Lonergan uttrykker det slik: «A heuristic notion, then, is the notion of an unknown content» (Lonergan, 1992, s. 417).

For Dupré er verdighetsbegrepet selve nøkkelbegrepet for humaniseringen av europeiske samfunn. For henne er det en sammenheng mellom verdighet og en demokratisk sivilisasjon. Hun skriver: «human dignity, creates a particular type of democratic 'civilisation'» (Dupré, 2012, s. 265), og videre "the connection between dignity and democracy are now beyond doubt» (Dupré, 2015, s. 183). Menneskeverdbegrepet setter derfor en standard for hvordan vi behandler hverandre på en sivilisert måte, ifølge Dupré.

Respect and protection of human dignity form part of a wider sense of right and wrong, which is deeply intuitive and rooted in a particular cultural understanding and form part of a civilised manner of relating to each other. (Dupré, 2012, s. 274)

Verdighet er en kjerne i et sivilisert samfunn. Det innebærer at borgerne i denne kulturen utvikler forventninger til hvordan et samfunn skal behandle mennesker: «being part of a 'civilised society' creates certain expectations about how to be treated» (Dupré, 2012, s. 273).

I sin forståelse av verdighetsbegrepets sentrale innhold bygger Dupré på flere av de mest sentrale moralske forståelser av begrepet innen filosofien. For henne knyttes menneskeverd til menneskets autonomi (s. 33-36), likeverd (s. 37f), frihet (s. 31-33) og det hun beskriver som begrepets vanlige 
betydninger, slik som anstendighet (decency) og (selv)respekt. (Dupré, 2015, s. 17). Dette er etablerte moralske forståelser av verdighetsbegrepet.

En av de største endringene i verdighetsbegrepets utvikling skjedde da verdighet gikk fra å være et begrep knyttet til eliten i samfunnet, til å gjelde ethvert menneske. Ifølge Dupré finner noe av denne utviklingen og nytolkningen sted i lovdannelser og ved domsbeslutninger i retten. Hun bruker et eksempel fra menneskerettighetsdomstolen i Strasbourg, hvor en mann dømt for voldtekt av sin ektefelle gikk til sak mot Storbritannia fordi han mente at det ikke var straffbart å voldta ektefellen ifølge rettslig tradisjon i landet. Mannen fikk ikke medhold i Strasbourg. Dupré finner eksemplet betydningsfullt fordi dommen begrunnes med respekt for menneskeverdet (Dupré, 2015, s. 99-103). Verdighetsbegrepet anvendes i privatsfærens mest intime områder, noe som ifølge Dupré var en ny anvendelse av begrepet i rettslig sammenheng.

I Duprés analyse er det blant annet gjennom demokratiets lover og prosesser at innholdet i, og implikasjonene av, verdighetsbegrepet blir utviklet. Hun mener demokratiske prosesser bidrar til å fylle begrepet med innhold, og det er gjennom disse at hva som menes med menneskeverdig liv, kommer til uttrykk. Menneskeverdet er derfor ikke bare viktig for individet. Det har betydning på et politisk og juridisk nivå.

The concept of human dignity is much more than the individual sense of self-respect and respect of others, it positions human beings at the heart of democracy, determining thus the exercise of political power. (Dupré, 2012, s. 264)

For Dupré innebærer denne demokratiske forankringen av verdighetsbegrepet en sterk kritikk av religion. Hun mener teologiske tolkninger, der det er gud som i ytterste forstand gir mennesker deres verdighet, er uforenelig med det moderne begrepet. Det er folk selv som bestemmer hva verdighet betyr. Demokratiet tar makten bort fra teologene. Oppdragsgiver er ikke Gud, men mennesker.

... democracy is about taking the ultimate political power away from God and his representative on earth. ... It is the rejection of God from the political equation that historically made it possible to turn human beings into citizens and actors in their political destiny. (Dupré, 2015, s. 19) 
Hun legger til grunn at det er folket selv som gjennom en åpen offentlig og transparent prosess kommer fram til hva verdighet betyr, og hvilke rettigheter man vil bevilge seg. Hun mener verdighet er et offentlig anliggende, et res publica, hvor fellesskapet som kollektiv må utvikle den normative plattformen for hva verdighet er.

Human dignity as res publica therefore requires that the determination of the boundaries of humanity and the normative scope of dignity have to be determined in public and transparent manner. (Dupré, 2015, s. 22)

Dupré ser dermed en avgjørende kobling mellom demokrati og verdighet. Menneskeverdet blir det viktigste moralske begrepet for demokratiet: «human dignity is the 'highest moral notion of democratic humanity'» (Dupré, 2015, s. 70). Verdighet betinger demokrati og gjør samtidig demokratiet nødvendig. Motsatt er det demokratiet som tilfredsstiller implikasjonene av menneskeverdet. Hvordan dette grunnlaget mer generelt utvikles $i$ et demokrati drøfter hun ikke i dybden. Hennes interesse er i første rekke lovgiveres og rettens bidrag i utviklingen av det felles normative grunnlaget.

Et annet grep Dupré gjør, er å sette verdighetsbegrepet inn i et tidsperspektiv. Hun tar opp antikkens to begreper for tid, kronos og kairos, for å synliggjøre det hun mener er «human dignity's transformative function» (Dupré, 2015, s. 158). Tid som kronos er gjentagende forutsigbar og stabil tiden flyter. Kairos, derimot, er tid som oppbrudd og endring - «time of rupture and discontinuity» (Dupré, 2015, s. 157). Kairos innebærer forandring og brudd med fortiden - samfunn og individers liv endres. Dupré plasserer verdighetsbegrepet i hovedsak under Kairos. Verdighetsbegrepet har etter hennes mening kommet klarest til uttrykk der omforminger av samfunn har funnet sted. Etter krigens ødeleggelser og nazismens fall ga verdighetsbegrepet en mulighet for en ny begynnelse, med demokratier basert på menneskeverd. Den samme prosessen fant sted på 70 -tallet. da Spanias, Hellas og Portugals diktaturer falt. Verdighetsbegrepet fikk betydning som en grunnleggende verdi i de påfølgende konstitusjonene og ble retningsgivende for de nye demokratiene. Dette skjedde på nytt etter kommunismens sammenbrudd på 1990-tallet. Dupré viser hvordan verdighetsbegrepet spilte en nøkkelrolle i den demokratiserende prosessen ved alle disse tre korsveiene: 
One recurring feature of human dignity is its association with new beginning(s) and democracy's "capacity to begin anew" by re-constructing dreams and projects ... human dignity is a tool used by constitutions to make space for and create a break in the continuous flow of time, ... to mark the beginning of a new democratic time. (Dupré, 2015, s. 157)

Det transformative aspektet ved verdighet er meget sentralt for Dupré. Menneskeverdighetsbegrepet, i en konstitusjonell kontekst, bidro til demokratisering. Det leder til forbedringer og bedre vilkår for mennesker.

For Dupré kommer innholdet og betydningen av «verdighet» fram nettopp i de endringene det leder til. Definisjonen av begrepet er avhengig av i hvilken grad og på hvilken måte verdighetsbegrepet bringer forbedringer og påvirker endringer, hvordan det reduserer lidelser, og bidrar til mer rettferdighet og demokrati. Betydningen av verdighet ligger i de forskjeller begrepet har brakt i konkrete situasjoner:

Human dignity: its substantive definition is arguably to be sought (and found) in the difference that the concept introduces to the law and in the impact it has on a given situation. (Dupré, 2015, s. 160)

Allikevel er ikke innholdet i verdighetsbegrepet begrenset til summen av endringer menneskeverdsideen har medført. Det unndrar seg denne begrensningen: «human dignity is an (a priori) abstract principle that can only be defined a posteriori as illustrated by a range of concrete examples, but never be exhausted in the sum of its parts» (Dupré, 2015, s. 160). Verdighet er derfor, ifølge Dupré, 1) både noe som kommer til uttrykk i lovgivning, men som også står utenfor loven, 2) både samtidig/nåtidig, og noe som er utenfor eller bortenfor tiden, og 3) det er til stede i demokratiske prosesser, og samtidig utenfor disse som kritiske og transformative (Dupré, 2015, s. 167-169). Hun beskriver disse tre trekkene nærmere slik:

1. Loven vil aldri bli identisk med menneskeverdet, det strekker seg utover det juridiske begrepet («Out of law reach»), (Dupré, 2015, s. 167). Det vil alltid ha en distanse til de lover og rettigheter som skal være grunnlag for anvendelse av begrepet i praktiske handlinger. Det er ingen gitt tekst, konstitusjon, ei heller menneskerettighetene, som er identisk med verdighet. 
2. Dupré mener begrepet står utenfor tiden og har et konkret innhold, en essens («eternity clause»). Hun forstår denne «utenfor-tidendimensjonen» som fylt av en uforanderlig kjerne som «the ultimate guarantee of democracy» (Dupré, 2015, s. 169).

3. Verdighet har et granskende aspekt, det kan være en kilde til kritikk av hvordan ting fungerer i det bestående.

Jeg tolker henne til å mene at menneskeverdet er en målestokk på hvordan vi behandler svake grupper i samfunnet, for eksempel funksjonshemmede, eldre, utviklingshemmede, flyktninger og minoriteter. Begrepet er et ideal som vi kan måle samtiden og de fungerende rettigheter og lover opp mot. På den måten blir menneskeverdet en guide for hvordan dommere kan anvende det på nye måter i uprøvde saker, og hvordan demokratiet kan forbedres, slik at menneskeverdet i stadig større grad kan gjennomføres i praksis og i lover.

Human dignity's primary role is not to bring a ready-made answer, but to guide judges as they venture into new territories, to encourage them to consider the "what if" question raised by the applicants. (Dupré, 2015, s. 159)

Tidsaspektet ved Duprés forståelse av verdighetsbegrepet kommer også til uttrykk på andre måter. Det handler om verdighet i faktiske livene vi lever, og den tiden vi har til rådighet. Hun snakker om respekt for plural tid. Det vil si den tid det enkelte mennesket disponerer i sitt liv. Verdighet skal bidra til å sikre menneskers tid, hvor de kan leve gode liv,

the freedom to construct one's own time ... human dignity as time of one's own is therefore the constitutional tool that creates and maintains a time in which humanity can flourish. (Dupré, 2015, s. 152)

Hun drøfter et interessant eksempel på individuell tid: En kvinne i England, som bor i egen omsorgsbolig, trengte hjelp til å gå på toalettet. Skulle hun få til det, innebar det at assistentene hennes var hos henne 1 time mer hver kveld. Det ville ikke institusjonen som hadde ansvar for omsorgen, de mente det var for kostbart. De bestemte at hun måtte bruke bleier til tross for at hun ikke var inkontinent. Omsorgsinstitusjonen respekterte ikke pasientens behov for egen tid. Dupré mener dette er en krenkelse av 
kvinnens verdighet, og at eksemplet illustrerer tidsaspektet ved verdighet. Menneskeverdet bidrar til å endre tiden, historien, men det handler også om levd tid for den enkelte. Å bli behandlet med verdighet er å bli gitt tid. Mange sykehjemsbeboere i dag opplever daglige krenkelser som konkret er knyttet til tid: Det er ikke tid for dem. Det interessante her, er at tid blir en dimensjon i verdighetsbegrepet.

Verdighetsbegrepet kan knyttes til tid også i forbindelse med livets begynnelse og slutt, og med hensyn til kommende generasjoner. Da verdighetsbegrepet slo igjennom som grunnleggende verdi, var det livet fra fødsel til grav som skulle beskyttes. Ny teknologi har gjort livets start mer utydelig. Verdighetsbegrepet må avklares i møte med nye medisinske muligheter for nedfrysing og kunstige befruktninger. Også i andre enden av livet utfordres verdighetsbegrepet: Skal livet avsluttes med naturlig død, eller skal mennesker selv ha en innflytelse på hvordan og når? Tidsaspektet handler også om kommende generasjoner og menneskeheten som sådan. Man må ta hensyn til de som enda ikke er født. Deres liv påvirkes av våre valg. Dupré nevner kloning av mennesker og genetisk modifisering av mennesker som eksempler. Hvis det tillates, vil det endre arvemassen. Dupré støtter at verdighetsbegrepet benyttes til å sette opp lovverk mot slike endringer. Hun mener man skal holde seg til den «naturlige» arvemassen, ikke «spille» med framtidens generasjoner, og ikke utvikle en ny type menneske. Verdighetstanken bidrar slik også til å sikre framtidens generasjoner.

Dupré argumenterer for at verdighetsbegrepet er en respons på grufulle historiske hendelser. Verdighetsbegrepet uttrykker et ideal, en visjon om endring og en ny framtid eller ny begynnelse. Det representerer håp om en mer rettferdig verden og en slutt på lidelse. Det representer optimisme og transformasjon, det gir håp og motiverer til å løfte mennesker som lever i nedverdigende forhold, opp til et liv i verdighet;

human dignity can be understood as that of a powerful ideal that captured the imagination and dreams of philosophers across centuries. (Dupré, 2015, s. 30)

Et poeng Dupré selv ikke legger så stor vekt på i sin tolkning av verdighetsbegrepet, er den konserverende dimensjonen som hun også plasserer det i. Det er både Kronos og Kairos, hvor hun selv vektlegger Kairos. 
I likhet med McCruddens framstilling av verdighetsbegrepets kjerne trekker Dupré fram en uforanderlig dimensjon. Selv om hun selv vektlegger det åpne og nyskapende, er retningen på endringene stabil og bestemt av denne kjernen. For meg er det derfor en indre spenning i hennes posisjon. Hvis vekten ligger på at det er demokratiet, gjennom åpne prosesser, som fyller menneskeverd med innhold, da er det et begrep som innholdsbestemmes nedenfra. Samtidig argumenterer hun for at begrepet er heuristisk. Det er et overskudd av innhold i begrepet, som ligger utenfor tiden. Verdighetsbegrepet har en essens. Da blir det en motsetning mellom begrepets på forhånd gitte innhold og demokratiske prosesser som fyller det med innhold. Dupré blir beskyldt for å komme nær en teologi som hun selv er så kritisk til (Mavronicola, 2015). Demokratiet ligger innebygd i verdighetsbegrepet, men det er ikke demokratiet som faktisk fyller det med innhold. Demokratiet strekker seg mot en stadig dypere forstålse av noe som på forhånd er gitt. Menneskeverd som heuristisk begrep blir dermed et naturrettslig prosjekt. Demokratiet kan bidra, men da tilå avdekke et betydningsoverskudd som allerede ligger som mulighet i verdighetsbegrepet. Hvis min analyse er riktig, er menneskeverdbegrepet hos Dupré primært gitt, og det må omsettes til demokrati, men demokratiet står ikke fritt til å fylle begrepet med et hvilket som helst innhold.

Dupré åpner begrepet med sin tolkning av verdighet som heuristisk. Hun politiserer og rettsliggjør det, samtidig som hun forankrer det $\mathrm{i}$ moral. I McCrudden blir menneskeverdet noe pent og pyntelig som sikrer noe grunnleggende, basert på konsensus. For Dupré, derimot, er begrepet langt mer dynamisk. Det har i seg en kraft og endringspotensial som mangler hos McCrudden. Samtidig står hun splittet tilbake med et menneskeverdbegrep som på sett og vis er naturrettslig og samtidig åpent og demokratisk. Det synes vanskelig å forene disse to sidene i hennes prosjekt.

Dupré tolker begrepet til å utvikle verdighet for dem som ikke har det. Hun ser arbeideres rettigheter som eksempler på dette; de har fått en bedre livskvalitet. I likhet med henne har Costas Douzinas også en interesse for hvordan de som er krenket, kan forandre sine liv. Der Dupré er opptatt av konstitusjon og bedre livsvilkår, er Douzinas også opptatt av lov, men i tillegg hva denne type ideer gjør med mennesker. 


\section{Verdighet som «flytende signifikant»}

Som allerede nevnt diskuterer ikke Douzinas verdighetsbegrepet som sådan. Hans interesse er menneskerettigheter og forståelsen av mennesket slik den kommer til uttrykk gjennom disse. Rettighetene konstrueres med utgangspunkt i en abstrakt forståelse av hva man mener alle har felles, en menneskelig essens. Douzinas stiller seg kritisk til om det finnes en slik essens. Han mener begrepet «menneske» i menneskerettighetene er «en flytende signifikant» (Douzinas, 2000, s. 255, 2007, s. 55).

"Floating" signifier is variously defined as a signifier with a vague, highly variable, unspecified or non existent signified. Such signifiers mean different things to different people: they may stand for many or even any signifieds; they may mean whatever their interpreters want them to mean. (Chandler, 2007, s. 250)

En «flytende signifikant» regnes som flytende fordi den ikke har et presist avgrenset innhold, men den kan fylles på et mangfold av måter. Den utvikler seg gjennom sammenhenger som ligner andre hvor det har vært brukt tidligere, men samtidig endrer eller utvider det betydningen.

Et kort tilbakeblikk på rettighetshistorien viser at de som fikk tildelt rettigheter gjennom rettighetserklæringer, var et svært begrenset antall. Den språklige formen har vært universell, mens det i realiteten har dreid seg om en liten gruppe hvite menn. Den franske erklæringen av $1789 \mathrm{er}$ protypen på det. Begrepet menneske i disse rettighetene angikk i realiteten en elite. Etter hvert har nye grupper, som slaver, arbeidere, kvinner, religiøse minoriteter, osv., kjempet seg til like rettigheter. Dette ble, om enn i en annen grad, også en problemstilling etter 1948. Hvem er mennesket i menneskerettighetene? Hvem er inkludert, og hvem er ekskludert? Butlers (Butler, 1996) anliggende ligner Douzinas', og hun peker blant annet på at menneskerettighetene slik de er formulert, angir heterofili som norm, og inkluderer ikke homofile og lesbiske. Rettighetene bygger på en bestemt familieforståelse som forutsetter ekteskap som et forhold mellom mann og kvinne. Når LHBT-grupper i dag påberoper seg menneskerettigheter og menneskeverdet i sin kamp for anerkjennelse, er det et eksempel på nytolkning av verdighetsbegrepet og menneskerettighetene. De kjemper for å bli inkludert i verdighetsbegrepet. De vil endre 
forståelsen av at ekteskapelig kjærlighet (det er familien og ekteskapet som gjelder i menneskerettighetene) også kan gjelde homofil og lesbisk kjærlighet. Det er en mangel på samsvar mellom konkrete mennesker og det abstrakte mennesket som man finner i lover som blant andre menneskerettighetene. "The formalism of law make the legal person an empty vessel or cipher and hinder the recognition of his concrete, unique characteristics» (Douzinas, 2007, s. 41). En abstrakt generell forståelse av mennesket vil ikke kunne dekke menneskers liv slik det leves. Det er en uoverensstemmelse som ikke kan harmoniseres, derfor er det viktig hvilket innhold og hvilken forståelse av mennesket som fyller loven.

Douzinas hevder at «mennesket» $\mathrm{i}$ MR er en «flytende signifikant», men han sier ikke noe spesifikt om menneskeverdbegrepet. Allikevel tillater jeg meg å tolke hans bruk av begrepet «flytende signifikant» om mennesket også til å gjelde menneskeverdet. Implisitt i «mennesket» slik det anvendes i menneskerettighetene, ligger en oppfatning av at det har verdighet. Verdighet er uløselig knyttet til mennesket slik det beskrives i menneskerettighetene. De to begrepene har ikke en lik historie, men i denne sammenhengen er det et betydelig sammenfall. Begge begrepene er i denne konteksten normative.

Douzinas avviser ideen om at mennesket har en iboende verdighet: «Humanity has no intrinsic normative value» (Douzinas, 2007, s. 57). Slik jeg tolker han, mener han med dette at hvis mennesker hadde verdigheten i naturen, ville det ikke ha vært nødvendig å utvikle menneskerettighetene. I Douzinas' rasjonale er den iboende verdien noe som proklameres. Det tilskrives mennesket. Menneskerettigheter er nødvendige for å sikre og gi mennesket verdighet. Verdigheten får et innhold nedenfra. Når menneskeverdet proklameres, får det også en funksjon av noe utvendig som kan anvendes som målestokk og visjon. I tråd med dette forstår Douzinas menneskerettighetene som noe som former mennesker. «Rights do not just belong to human, rather, they make human», skriver han (Douzinas, 2000, s. 261). Mennesker forstår seg som bærere av rettigheter og verdighet:

... dignity, the universal attribute of humanity. The legal mentality teaches us to respect others as right-holders whose legitimate claims will be honoured as much as ours. (Douzinas, 2007, s. 40) 
10. desember 1948 fikk menneskerettighetene og menneskeverdet gjennomslag gjennom FNs vedtaket av verdenserklæringen om menneskerettigheter. Det var en begivenhet som skapte og skaper endringer. Menneskeverdet åpner for nye måter for mennesker å se seg selv, hverandre og samfunnet på. Mennesker som ikke har sett på seg selv som verdige, men tvert om forstått seg selv som uverdige, f.eks. daliter, kan gjennom kunnskap om menneskeverdet endre syn på seg selv, og derigjennom utvikle selvrespekt. Undertrykte kan gjennom kunnskapen om menneskeverdet endre selvforståelsen, og dermed gjøre krav på liv i verdighet. Kunngjøringen om den iboende verdigheten gir dem en annen status.

Med Douzinas' utgangspunkt kan en stille spørsmål om hvem verdigheten gjelder, og hvordan den kommer til uttrykk. Lovens formuleringer vil ikke nødvendigvis innebære verdighet for enhver, tross lovens universelle form. Menneskeverdet må tolkes, anvendes, og fylles med innhold i møte med og på bakgrunn av menneskers erfaringer og behov. Når mennesker våkner og blir klar over avstanden mellom menneskeverdet og det livet de lever, vitaliseres menneskerettighetene og menneskeverdet. På den måten vil ulike grupper og variasjoner i levemåter utfordre tolkninger av menneskeverdbegrepet og fylle det med nytt innhold. Urfolk, personer med funksjonsnedsettelser, samt mange andre, har tatt i bruk verdighetsbegrepet i kampen for sine rettigheter og verdige liv.

Selv om begrepet mennesket i MR for Douzinas er en «flytende signifikant», så er det ikke tomt. Det har en stor symbolsk kraft. Derfor egner menneskerettighetene og verdighetsbegrepet seg i politiske kamper. De gir ammunisjon og redskaper for endring:

the "humanity" of human rights is not just an empty signifier; it carries an enormous symbolic capital, a surplus of value and dignity endowed by the Revolutions and the Declarations and augmented by every new struggle for the recognition and protection of human rights. (Douzinas, 2002, s. 399)

I mange sosiale og politiske kamper er menneskerettigheter og menneskeverdet noe man ønsker å ha på sin side. Et eksempel er kampen for assistert selvmord og aktiv dødshjelp, der verdighetsbegrepet konkret tas i bruk gjennom å hevde retten til å dø med verdighet. 
This symbolic excess turns the "human" into a floating signifier, into something that combatants in political, social and legal struggles want to co-opt to their cause, and explains its importance for political campaigns. (Douzinas, 2007, s. 55f)

Det er en potensiell sprengkraft i verdighetsbegrepet. Men en politikk som hevder å være basert på menneskeverd, er ikke nødvendigvis en garantist for menneskeverdet. Mange krenkelser kamufleres under retorikken om menneskets iboende verdighet. Dette er også noe Upendra Baxi drøfter (Baxi, 2006). Man kan appellere til menneskeverd og menneskerettigheter, men samtidig opprettholde krenkende strukturer. For eksempel var det kriminelt å være homofil i Norge fram til 1972.

Mennesker som søker verdighet, har gjerne utfordringer som hindrer dem fra et liv i verdighet. Disse hindringene kan være helt annerledes og utenkte for dem som i sin tid utviklet rettighetene. Innholdet i verdighetsbegrepet vil endres ut fra nye kontekster, som i eksemplet over med LHBT. Det viser at til tross for den universelle formen, eller kanskje nettopp på grunn av den, er det viktig å se hva egentlig menneskeverd og iboende verdighet betyr, og stille spørsmål om hvem som ekskluderes, og hvem som inkluderes.

Det er lett å krenke mennesker. Samtidig må man spørre: Hvorfor skal man proklamere menneskers verdighet, hvorfor er det galt å behandle mennesker dårlig? Menneskeverd er noe vi ønsker å ha, noe vi tror er godt for individ og samfunn. Dette spørsmålet besvarer ikke Douzinas med sin forståelse.

\section{Sluttkommentar}

Jeg har sett på menneskeverdbegrepet gjennom tre fortolkninger som hver på sin måte kaster lys over et sentralt, men gåtefullt begrep. Det er vanskelig å fange betydningen av menneskeverdet. Like fullt er det et viktig begrep. Menneskeverdet er en grunnverdi i den vestlige kulturen. Det betyr ikke at det ikke også er relevant i andre kulturer.

Slik jeg leser McCrudden, er pluraliteten av tolkninger av menneskeverdet et sentralt poeng i seg selv. Hans forståelse av begrepet som placeholder er et resultat av den erkjennelsen. Det lar seg kombinere og lese inn 
i et mangfold av teologiske og filosofiske og juridiske tradisjoner. I et slags forsvar for verdighetsbegrepet søker McCrudden mot det som er felles i tolkningene av begrepet, placeholderens stabile funksjon. McCrudden fant tre kjernepunkter som er felles. Menneskeverdet er noe iboende, som alle har. Videre har man et ansvar for andre på grunn av deres verdighet, og til slutt legges verdigheten til grunn og regulerer forholdet mellom staten og borgerne. Blant majoriteten av dem som anvender begrepet, er nok dette treffende. Han søker ikke begrunnelsene for de enkelte elementene. Det viktigste blir å få plassert begrepet som en felles grunnverdi.

En av de McCrudden (2013b, s. 11f) forholder seg kritisk til, er Douzinas, som ikke deler hans oppfatning om at menneskeverdet er iboende. Douzinas har rett i at mennesker er lett å krenke, og at det foregår mye både i historien og i vår samtid som viser at mennesker krenkes på det groveste av andre mennesker. I Douzinas' drøfting forskyver han fokuset fra essensielle menneskelige kjennetegn til menneskeverdet som et politisk verktøy for rettferdighet. Når vi hevder at menneskeverd finnes, er det ikke en beskrivelse av hva mennesket er av natur, eller hva mennesker gjør, men det er en visjon. Det er en visjon vi selv må ta ansvar for. Vi har skapt og proklamert prosjektet menneskeverd. Med det har vi introdusert et kraftfullt og virkningsfullt redskap.

McCrudden opererer innenfor en tradisjonell liberalfilosofisk ramme. Han er opptatt av samfunnets grunnverdier og av å sikre alle et minste minimum av rettigheter og menneskeverd. I hans prinsipp om å tilkjenne andre samme rettigheter som en selv, ligger en forståelse av menneskeverd som gjensidighet. Allikevel blir dette ofte en formell gjensidighet. Med det mener jeg at alle har de samme rettigheter og muligheter på papiret og i loven, men ikke nødvendigvis i livet. Vi vil ha menneskerettigheter og bli behandlet med verdighet, men McCrudden utvikler ikke den mulige samfunnskritikken som ligger i verdighetsbegrepet. Både Duprés og Douzinas' fortolkninger gjør verdighet til et langt mer dynamisk og progressivt begrep enn McCrudden.

Dupré forstår begrepet menneskeverd som heuristisk. Sider ved denne forståelsen er interessante. Menneskeverdbegrepet utvikles gjennom gjetninger, antagelser og sprang. Det har ikke en avgrenset og avklart betydning som ligger fast, men åpner for nye muligheter og nye områder 
å anvende det på. Først i ettertid vil man kunne vurdere om det traff. Menneskeverdet rommer mange aspekter, det blir i denne sammenhengen et kreativt og nyskapende begrep. Hun viser dette blant annet gjennom å se på menneskers tilgang til egen tid og det hun kaller plural tid. Tid er viktig for den enkelte, samtidig innebærer tid veldig ulike ting for mennesker avhengig av livsfaser og de liv vi lever. Verdighetsbegrepet blir ikke bokset inne i en konsensus, men slippes fri tilå utfordre det etablerte og nye livsområder.

Framtredende ved hennes tolkning er koblingen til kairos. Menneskeverdighet kommer til sin rett i tider med oppbrudd og transformasjoner, når diktaturer faller og menneskeverdet kommer inn som grunnlag for en demokratisk retning på samfunnet, slik som i Europa etter 2. verdenskrig. Hun kobler demokrati og menneskeverd tett sammen, som McCrudden, men på en annen måte, ved at hun vektlegger begrepets medvirkning til transformasjon. Både McCrudden og Dupré ser begrepet som basis i og for demokratier, men Dupré vektlegger i tillegg endring. Hun har videre også en sosial profil på sin tolkning av begrepet, hvor hun mener det har bidratt til arbeideres rettigheter og verdige liv. Hun anvender det også til å beskytte framtidige generasjoner og menneskets arvemasse.

Dupré havner for meg i en spagat når hun på den ene siden mener at det er demokratiet som skal definere og fylle verdighetsbegrepet med innhold. Samtidig hevder hun at det er et heuristisk begrep med reelt innhold som avdekkes, noe som har et innhold utenfor tiden. Hun hevder at menneskeverdet står utenfor tiden, har en essens. Den heuristiske metoden åpner for sprang, uventede vendinger i tolkninger og anvendelse av verdighetsbegrepet, men drar med seg en spekulativ ontologi. Hvis man aksepterer min tolkning av Douzinas, og overfører hans begrep «flytende signifikant» til også å gjelde menneskeverdet er det mennesker selv som fyller det med innhold; begrepet er immanent. Det er vi som tolker og gir det mening, det er vår visjon. Det gjør ikke begrepet mindre reelt. Verdighet som en «flytende signifikant» er et strategisk og viktig begrep. Det er et begrep som man i dag vil ha på sin side i de politisk moralske kampene.

Mennesker kan endre syn på seg selv når de blir kjent med tanken om menneskeverd. For mange har det vært transformerende og gitt selvrespekt og stolthet, særlig for grupper som har levd under uverdige 
forhold. Douzinas plasserer arenaen for menneskerettigheter, og jeg legger til menneskeverd, der hvor mennesker strever og kjemper for seg selv eller andre, strever for verdighet. Begrepet lever av og gjennom den appellen det har.

En «flytende signifikant» er per definisjon mulig å koble sammen med nesten hvilken som helst signifikant. Skal det være en signifikant betinger det at den har noe av placeholderens begrensninger innebygd, ellers er det meningsløst å kalle det en «flytende signifikant». Uten slike begrensninger vil den være helt tom. Tradisjonen har etablert noen tolkninger som skaper slike begrensninger. McCruddens tre elementer er i nærheten av disse. Det er skapt en kjerne av betydninger av begrepet som gjør det egnet som et kritisk nyskapende begrep.

Den Douzinas-inspirerte tolkningen åpner for noe av det samme som den heuristiske fortolkningen ga rom for. Begge vektlegger det nyskapende og det strategiske, det som gjør at man bruker det til å utvide rommet for hvem og hva som inkluderes i menneskeverdet. Det er en kontinuerlig kamp for svake gruppers verdighet i møte med demokratiets konserverende prioriteringer og privilegier, og autoritære regimers ignorering av menneskeverdet.

Vi lever ikke med en fasit i hånden over hva menneskeverdet er, slik man av og til kan få inntrykk av i menneskerettighetsdiskurser. Det kan heller ikke reduseres til noen få standardspørsmål som abort og aktiv dødshjelp. Den moralske grunnverdien menneskeverd er viktig, men det er opp til oss å forvalte og tolke den. Det er vårt ansvar å holde liv i den, fylle den med innhold og gjennomføre den. Det bør stimulere til å utvikle sensitivitet for når menneskeverdet krenkes. Med McCrudden kan man si at «dignity becomes a useful vehicle for an expanding idea of empathy» (McCrudden, 2013a, s. 13) - empati også med dem som enda ikke er født, og sørge for at de har muligheten for verdige liv.

Menneskeverdighet er en sentral verdi i og for demokratier. Det er en politisk, juridisk og moralsk verdi som bør danne grunnlag for et samfunnskritisk blikk. Det er en verdi som kan installere håp, og inspirere til endring.

Once it is acknowledged that what is at stake in human rights is the dignity of the person, the possibility of different manners of envisaging this question 
becomes evident, as well as the different ways in which it can be answered. Indeed, what western culture calls "human rights" is a culturally specific form of asserting dignity of the person and it would therefore be very presumptuous to declare that it is the only legitimate one. (Mouffe, 2014, s. 189)

\section{Forfatterbiografi}

Ådne Valen-Sendstad er førsteamanuensis ved Universitet i Sørøst-Norge ved Fakultet for humaniora, idrett og utdanningsvitenskap. Han har en PhD fra University of Birmingham. Han arbeider med etikk, filosofiske forståelser av menneskerettigheter og menneskerettighetsundervisning. Han har publisert om menneskerettigheter i skolen, barnets beste, demokrati og normativ pluralisme.

\section{Referanser}

Bajaj, M. (2012). Schooling for Social Change: The Rise and Impact of Human Rights Education in India. New York, London, New Delhi, Sydney: Bloomsbury.

Baxi, U. (2006). The Future of Human Rights. Oxford, New York: Oxford University Press.

Butler, J. (1996). Universality in Culture. I J. Cohen (Red.), For Love of Country. Boston: Beacon Press.

Chandler, D. (2007). Semiotics. London \& New York: Routledge.

Daly, E. (2013). Dignity Rights. Philadelphia: University of Pennsylvania Press.

Douzinas, C. (200o). The End of Human Rights. Oxford: Hart Publishing.

Douzinas, C. (2002). Identity, Recognition, Rights or What Can Hegel Teach Us About Human Rights? Journal of Law and Society, 29(3), 379-405.

Douzinas, C. (2007). Human Rights and Empire: The political philosophy of cosmopolitanism. Abingdon, UK and New York, USA: Routledge-Cavendish

Dupré, C. (2012). Dignity, Democracy, Civilisation. Liverpool Law Review, 33, 263-280.

Dupré, C. (2013). Human Dignity in Europe: A Foundational Constitutional Principle. European Public Law, 19(2), 319-339.

Dupré, C. (2015). The Age of Dignity. Oxford and Portland, Oregon: Hart Publishing. Habermas, J. (2010). The Concept of Human Dignity and the Realistic Utopia of Human Rights. Metaphilosophy, 41(4), 464-480.

Hughes, G. (2011). The concept of Dignity in the Universal Declaration of Human Rights. Journal of Religious Ethics, 39, 1-24.

Laclau, E. (2014). The Rhetorical Foundation of Society. London, New York: Verso. 
Lonergan, B. (1992). Insight: A Study in Human Understanding. Vol. 3 of Collected Works of Bernard Lonergan. Toronto: Toronto of University Press.

Mavronicola, N. (2015). Heeding Human Dignity's Call. Legal Studies, 36(4), 725-737.

McCrudden, C. (2008). Human Dignity and Judicial Interpretation of Human Rights. European Journal of International Law, 19(4), 655-724.

McCrudden, C. (2013a). In Pursuit of Human Dignity: An Introduction to Current Debates. I C. McCrudden (Red.), Understanding Human Dignity. Oxford: Published for The British Academy by Oxford University Press.

McCrudden, C. (Red.) (2013b). Understanding Human Dignity. Oxford: Oxford University Press.

McCrudden, C. (2014). The Pluralism of Human Rights Adjudication. I L. Lazarus, C. McCrudden \& N. Bowles (Red.), Reasoning Rights; Comparative Judicial Engagement. Oxford and Portland: Hart Publishing.

Mouffe, C. (2014). Democracy, Human Rights and Cosmopolitanism: an Agonistic Approach. I C. Douzinas \& C. Gearty (Red.), The Meanings of Rights; The Philosophy and Social Theory of Human Rights. Cambridge: Cambridge University Press.

Osler, A. (2016). Human Rights and Schooling; An Ethical Framework for Teaching for Social Justice. New York, London: Teachers College Press.

Rawls, J. (1996). Political Liberalism. New York: Colombia University Press.

Schickore, J. (2018). Scientific Discovery. I E. N. Zalta (Red.), The Stanford Encyclopedia of Philosophy https://plato.stanford.edu/archives/sum2018/entries/ scientific-discovery/

Shultziner, D. (2003). Human Dignity - Functions and Meanings. Global Jurist Topics, 3(3), 1-21. 
